

$10 / 6$

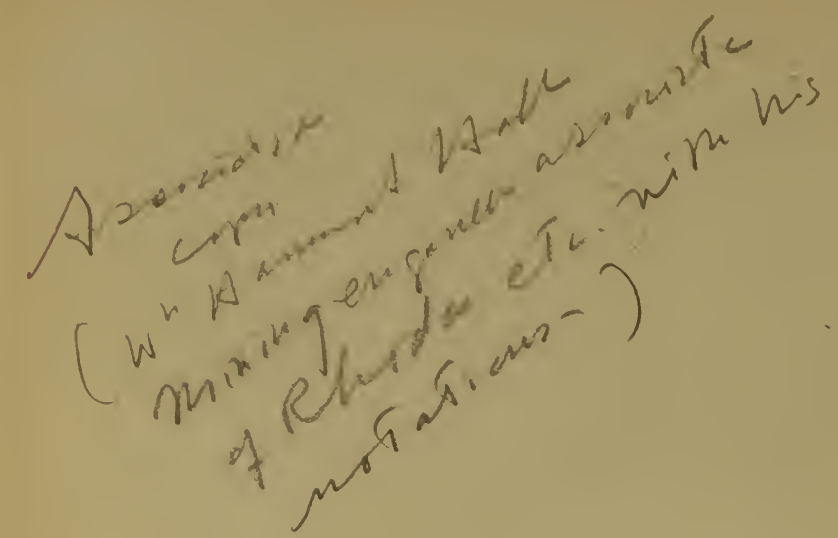




\section{IMPRESSIONS}

\section{OF SOUTH AFRICA}


L 
Richard Clay and Sons, Limited LONDON AND BUNGAY.

First Edition, November 1897 Reprinted, November 1897 Second Edition, January 1898 
To

THE COMPANION OF MY JOURNEY 



\section{PREFACE}

As I have explained in the introductory chapter the scope and plan of this volume, I need do no more here than acknowledge the assistance which I have derived in the historical part of it from two or three books, and especially from the treatises of Mr. Theal, a diligent and careful writer who has done much for the annals of his adopted country. I have also been aided by the interesting lectures on the Emigrant Boers in Natal of the late Mr. Cloete, and by the lucid and judicious "Historical Geography of the British Colonies" (vol. iv.) of Mr. C. P. Lucas. No special reference seems needed to the other works I have consulted, except to Mr. Noble's very well executed "Official Handbook of the Cape and South Africa."

I have to thank Sir Donald Currie and the Castle Mail Packets Company for the permission kindly given me to use the maps in the excellent "Guide to South Africa" (published by them) in the preparation of the three maps contained in this volume; and I trust that these maps will prove helpful to the 
reader, for a comprehension of the physical geography of the country is essential to a comprehension of its history.

The friends in South Africa to whom I am indebted for many of the facts I have stated and views I have expressed are too numerous to mention: but I cannot deny myself the pleasure of returning thanks for the genial hospitality and unfailing kindness which I received in every part of the country.

As I have been obliged to correct the proofs of this book at a distance from all books of reference, I ask indulgence for any minor errors which may be discovered in it.

James Bryce.

September I3, I 897.

\section{NOTE TO THE SECOND EDITION}

Some few corrections have been made in the text of this Edition, and there has been prefixed to it a list of the areas and populations of the several Colonies, Republics and Territories in South Africa, together with a table of dates of some important events in South African history.

December 29, 1897. 


\section{CONTENTS}

PREFACE ................ Pii

AREA AND POPULATION OF THE SEVERAL COLONIES, REPUBLICS AND TERRITORIES IN SOUTH AFRICA . . . . . . . . . . . . . . . . xix

DATES OF SOME IMPORTANT EVENTS IN THE HISTORY OF SOUTH AFRICA .. . . . . . . . xxi INTRODUCTION ............... . . xxiii

\section{PART I \\ $N A T U R E$ \\ CHAPTER I}

PHYSICAL FEATURES

The Coast Strip and the Great Plateau . . . . . 2

MOUNTAIN-RANGES . . . . . . . . . . . . 3

Climate . . . . . . . . . . . . . . . . 7

The AbSence of Rivers . . . . . . . . . . . . . 9

CHAPTER II

HEALTH

TEMPERATURE . . . . . . . . . . . . I I

DRYNESS OF THE AIR ............... . . . . . . . . . . . . . . .

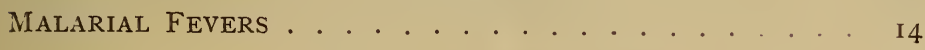

CHAPTER III

WILD ANIMALS AND THEIR FATE

Original abundance of Wild Creatures ...... i. i 8

Their Extinction : the Lion, Elephant, AND Rhinoceros $2 \mathrm{I}$

Recent Attempts at Protection . . . . . . . 24 


\section{CHAPTER IV}

VEGETATION

Character of the South African Flora ... . . 26

Native and IMPORTEd TREeS . . . . . . . . . . . . 29

Changes made by Man in the Landscape . . . . . . 35

\section{CHAPTER V}

PHYSICAL ASPECTS OF THE VARIOUS POLITICAL DIVISIONS OF THE COUNTRY

Cape Colony .................. . . . 37

Natal . . . . . . . . . . . . . . . . 40

German ANd Portuguese Africa .. . . . . . . . 4I

The Orange Free State and the South African

Republic. . . . . . . . . . . . . . . . . . 43

Bechuanaland AND the Territories of the British

South Africa Company . . . . . . . . . . . 46

CHAPTER VI

NATURE AND HISTORY

Influence of Physical Conditions on the Savage RACES . . . . . . . . . . . . . . . 50

Slow Progress of Early European Settlement . . . 5 I

LAter Explorations along the Interior Plateau . . . 53

\section{CHAPTER VII}

\section{ASPECTS OF SCENERY}

Dryness and Monotony of South African Landscape. 58 Striking Pieces of Scenery : Basutoland, Manicaland 60 Peculiar Charm of South Africa: Colour and SoliTUDE . . . . . . . . . . . . . . . . 62 INFLUENCE OF SCEnery ON Character . . . . . . . 67 


\section{PART II}

\section{HISTORY}

\section{CHAPTER VIII}

THE NATIVES : HOTTENTOTS, BUSHMEN, AND KAFIRS

The Aborigines : Bushmen and Hottentots ..... 7 I

THE BANTU or Kafir TRIBES . . . . . . . . . 78

\section{CHAPTER IX}

OUT OF THE DARKNESS-ZIMBABIVYE

Ancient Walls in Matabililand and Mashonaland . . 83 Dhlodhlo : Chipadzi's Grave. . . . . . . . . . 84

The Great Zimbabwye . . . . . . . . . . . . . . 90

THeories as to the BuILders of the ANCIENT Walls . 95

CHAPTER $\mathrm{X}$

THE KAFIRS: HISTORY AND INSTITUTIONS

The Kafirs before their Struggles with the Euro-

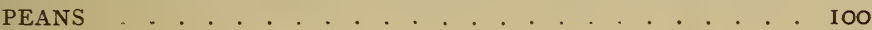

CAREERS OF DingISWAYO AND TSHAKA ....... IO I Results of THE ZULU ConqueStS . . . . . . . . . IO2 KAFIR InSTITUTIONS . . . . . . . . . . . . . . . 106 WAR, RELIGION, SORCERY _. . . . . . . . . IO8 Stagnation and Cruelty of Primitive Kafir Life. . . il 8

\section{CHAPTER XI}

THE EUROPEANS IN SOUTH AFRICA TILL I854 The Portuguese at Sofala . . . . . . . . . i i 20

The Dutch at the CAPE. The French Huguenots . I 24 The Africander Type of Life and Character . . . . I 29 
PAGE

Disaffection of the DUtch Settlers . . . . . . . I 132

BRitish Occupation of THE CAPE... . . . . . . . I34

Features of British Administration. . . . . . . . I35

Boer Discontent and its Causes . . . . . . . . . . I 37

ThE GReat TREK OF I836. . . . . . . . . . . . I4I

Adventures of the Emigrant Boers . . . . . . . . . I 44

The Boers and the British in Natal. . . . . . . . . I50

THE BoERS IN THE INTERIOR: BeginNings OF THE TwO

DUtCh RePUblics . . . . . . . . . . . . . . . I 54

British Advance : the ORANGe River SOVEREIGNTy . . I 59

THE SAND River Convention OF I 852 : INDEPENDENCE OF

the Transvah Boers ............. . I6I

The Bloemfontein Convention of i 854: Independence

of the Orange Free State . . . . . . . . . . . I63

\section{CHAPTER XII}

THE EUROPEANS IN SOUTH AFRICA, I854-95

Progress of Cape Colony : Material and Political . i66 GRANT OF RESPONSIBLE GOVERnMENT IN I872 . . . . . I72 KAFIR WARS: CaUSES OF THEIR FREQUENT RECURRENCE . I74 Renewed British Advance : Basutoland . . . . . . . 179 The Delagoa Bay Arbitration . . . . . . . . . . . 182 First Scheme of South African Confederation . . . i 83 THE ZUlu WAR OF I879... . . . . . . . . . . . . . . I 85 Formation of the Transvaal Republic . . . . . . . . 189 Annexation of the Transvaal . . . . . . . . . . igI Revolt of the TransvaAl : ITS INDEPENDENCE Restored I98 Boers AND BRitish in Bechuanaland . . . . . . . 205 The Conwentions of I884 AND I894: SWAzILAND . . . . 207 German Occupation of Damaraland........ . 2 Io The British SOUTH AFrica Company: Acquisition of MASHONALAND AND MATABILILAND ........ . 212 ReCent History of the TransvaAL: The Rising OF I895 216 


\section{PART III \\ A JOURNEY THROUGH SOUTH AFRICA}

CHAPTER XIII

TRAVELLING AND COMMUNICATIONS

Communications along the Coast . . . . . . . . 223

LINES OF RAILROAD . . . . . . . . . . . . . . . . . . . 225

TRAVELLING BY OX-WAGGON . . . . . . . . . . 227

CHAPTER XIV

FROM CAPE TOWN TO BULAWAYO

The Voyage to the CAPE ............ . . . 235

CAPE TOWn and its Environs . . . . . . . . . 240

THE JOURNEY INLAND : SCENERY OF THE KARROO . . . 242

KIMBERLEY AND ITS DIAMOND-FIELDS . . . . . . . . 245

NORTHWARD THROUGH BECHUANALAND . . . . . . . 252

Khama : his Town and his PeOPle . . . . . . . . 260

Mangwe ANd the MatopPo Hills . . . . . . . . . 268

\section{CHAPTER XV}

\section{MATABILILAND AND MASHONALAND}

Bulawayo and lo Bengula . . . . . . . . . 27 I

The Natives: Causes of the Rising of I896. . . . 275

The Native Labour Question . . . . . . . . 28I

Dhlodhlo : Scenery of the Hill-country . . . . . . 285

Gwelo and the Track to Fort Victoria . . . . . . 292

Ruins of Great Zimbabiwye. . . . . . . . . . . . . . 296

FORT SALISBURY . . . . . . . . . . . . 300 


\section{CHAPTER XVI}

FROM FORT SALISBURY TO THE SEA-MANICALAND AND THE PORTUGUESE TERRITORIES

P.AGE

Scenery of Eastern Mashonalínd... . . . . . . 303

Antiquities at the LezAPi River . . . . . . . . . . 308

Among the Mountains : Falls of THE OUdZI. . . . . . 313

Mtali ANd the Portuguese Border . . . . . . . . 316

Chimoyo AND the EASTERN SlOPF . . . . . . . . . . 324

Descent of the Pungwe River to Beira . . . . . . . 329

CHAPTER XVII

RESOURCES AND FUTURE OF MATABILILAND AND MASHONALAND

General Features of the British South Africa ComPANY'S TERRITORIES. . . . . . . . . . . . . . 338

Health, Wealth, AND PEACE . . . . . . . . . . 340

Results of BRitish Extension in the NoRth . . . . 349

\section{CHAPTER XVIII}

THROUGH NATAL TO THE TRANSVAAL

DelagoA BAY . . . . . . . . . . . . . . . . . 352

DURban AND PietermaritzbuRg. . . . . . . . . . . 354

The Government and Politics of Natal. . . . . . . . 356

Laing's NeK and Majuba Hill . . . . . . . . . . . 365

The WitwatersRand AND ITS Gold-FIEldS . . . . . . 37 I

Johannesburg AND PREtoria . . . . . . . . . . . . 383 


\section{CHAPTER XIX}

THE ORANGE FREE STATE

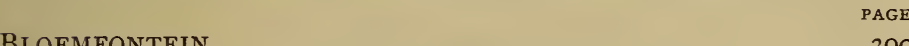

BloEMFONTEIN . . . . . . . . . . . . . . . . . . . . . . 390

Constitution and Politics of the Free State. . . . . 394

\section{CHAPTER XX}

BASUTOLAND: THE SWITZERLAND OF SOUTH AFRICA

Across the Free State to the Caledon River . . . 399

THE MissionaRies AND THE CHIEFS : LeRothodi . . . . . 403

The Ascent of Mount Machacha . . . . . . . . 406

THABA Bosiyo AND ITS History.... . . . . . . . 415

Condition and Prospects of the Basuto Nation . . . 42 I 


\section{PART IV \\ SOME SOUTH AFRICAN QUESTIONS}

\section{CHAPTER XXI}

\section{BLACKS AND WHITES}

Relative Numbers and Influence of EACH . . . . . 433

Social Condition and Habits of the Blacks . . . . . . 439 Aversion of the Whites FOR THE BlaCKS . . . . . . . . 44I Civil and Legal Rights of the Blacks . . . . . . . . . 446 What the Future of the Blacks IS LiKely to BE . . . . 459

\section{CHAPTER XXII}

\section{MISSIONS}

INFLUENCE OF THE RELIGIOUS IDEA ON VARIOUS RACES • . 464 How the Natives Receive THE MissionaRies . . . . . . . 466 SlOW Progress OF Mission WORK ... . . . . . . . 473

\section{CHAPTER XXIII}

SOCIAL CHARACTERISTICS OF THE BRITISH COLONIES

The Dutch and the English : the Dutch Language • 475 Placidity of South African Life . . . . . . . . . 482 Literature, JoURNALiSM, EdUCATION . . . . . . . . 483 The Churches . . . . . . . . . . . . . . . 487

\section{CHAPTER XXIV}

POLITICS IN THE BRITISH COLONIES

The Frame of Colonial Government . . . . . . . . 49 I Absence of Some Familiar Political Issues . . . . . 496 Real Issues : Race AND Colour Questions'. . . . . 498 General Character of Cape Politics . . . . . . . 50 I 


\section{CHAPTER XXV}

THE POLITICAL SITUATION IN THE TRANSVAAL IN I895

The Old Boers and the New Immigrants . . . . . . 507 Constitution AND GovernMENT OF THE REPUBLIC . . . 512 Uitlander Discontent : the National Union . . . . 516 The Capitalists: Preparations for a Revolution. . . 519 President KRUger and his Policy . . . . . . . 525 The Chances for the Movement : CaUSes of its FaILURe 532

\section{CHAPTER XXVI}

ECONOMIC PROSPECTS

Material Resources : Tillage and Pasture . . . . . 543

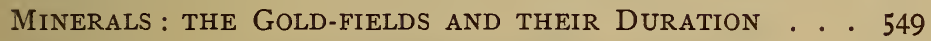
Will Manufactures be Developed? . . . . . . 556 SOUth Africa AS a MARKet For GoOdS . . . . . . 559 Future Population : its Increase and Character. . . 565

\section{CHAPTER XXVII}

\section{REFLECTIONS AND FORECASTS}

Sources of the Troubles of South Africa . . . . . 568 The Friction of Dutch and English : its CaUSES . . 570 British Policy in its Earlier and Later Phases . . . 570 Future Relations of the EURopean and Native Races 575 International Position of South Africa . . . . . 58I The Future Relations of Boers and Englishmen . 584 Prospects of South African CONFEderation . . . . 594 SoUth Africa ANd BRITAIN . . . . . . . . . . . 597

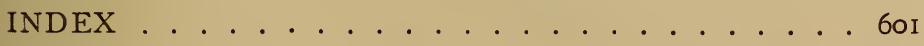




\section{MAPS AT END OF VOLUME}

Political Map of South Africa.

Orographical Map of SoUth Africa.

Rainfall Map of SoUth Africa. 


\section{AREA AND POPULATION OF THE SEVERAL COLONIES, REPUBLICS AND TERRITORIES IN SOUTH AFRICA}

\begin{tabular}{|c|c|c|c|c|}
\hline \multirow{2}{*}{\multicolumn{2}{|c|}{ Area in SQuare Miles. }} & \multicolumn{3}{|c|}{ Population in regr. } \\
\hline & & European. & Coloured. & Total. \\
\hline $\begin{array}{l}\text { British- } \\
\text { Cape Colony (including } \\
\text { Walfish Bay) } . . .\end{array}$ & 277,000 & 382,198 & $1,383,762$ & I, 765,960 \\
\hline Basutoland . . . . & I0, 293 & 578 & 218,624 & 219,202 \\
\hline $\begin{array}{l}\text { Bechuanaland (Protector- } \\
\text { ate) }\end{array}$ & 200,000 (?) & 800 (?) & 200,000 (?) & - \\
\hline Natal . . . . . . & 20,46 I & 46,788 & 497,125 & 543,913 \\
\hline Zululand . . . . & I 2,500 (?) & $\mathrm{I}, \mathrm{IOO}$ & I $79,270(?)$ & 180,370 \\
\hline Tongaland (British) . . . & 2,000 (?) & none & 20,000 (?) & - \\
\hline $\begin{array}{l}\text { Territories of British South } \\
\text { Africa Company, south } \\
\text { of the Zambesi (Mata- } \\
\text { bililand and Mashona- } \\
\text { land) }\end{array}$ & 142,000 & $\begin{array}{l}5,000(?) \\
(1896)\end{array}$ & unknown & - \\
\hline $\begin{array}{l}\text { Independent- } \\
\text { South African Republic } \\
\text { (Transvaal) . . . . }\end{array}$ & I I 9, I 39 & 245,397 & $622,500(?)$ & 867,897 \\
\hline $\begin{array}{l}\text { Swaziland (dependent on } \\
\text { South African Republic) }\end{array}$ & 8,500 & 900 (?) & 55,000 (?) & - \\
\hline Orange Free State . . & 48,326 & 77,716 & I 29,787 & 207,503 \\
\hline Portuguese East Africa & 300,000 (?) & I0,000 (?) & $3,100,000$ (?) & - \\
\hline German East Africa & $320,000(?)$ & $\begin{array}{l}2,025 \\
(1896)\end{array}$ & 200,000 (?) & - \\
\hline
\end{tabular}





\section{DATES OF SOME IMPORTANT EVENTS IN THE HISTORY OF SOUTH AFRICA}

Bartholomew Diaz discovers the Cape of Good Hope .. A 1486

$\checkmark$ Vasco da Gama explores the East Coast of Africa . . . . 1497-8

$\checkmark$ The Dutch appear in the South African Seas . . . . . I 1595

$\checkmark$ First Dutch settlement in Table Bay . . . . . . . 1652

$\checkmark$ Arrival of French Huguenot settlers . . . . . . . . 1689

$\checkmark$ Beginning of the Exploration of the Interior . . . . . 1700

First Kafir War . . . . . . . . . . . . I779

First British occupation of the Cape . . . . . . . 1795-1803

Second British occupation of the Cape . . . . . . . . 1806

Cession of Cape Colony to Britain . . . . . . . . . 1814

Conquests of Tshaka, the Zulu King . . . . . . . 1812-1828

Arrival of a body of British settlers . . . . . . . . 1820

First British settlement in Natal ... . . . . . 1824

English made the official language in Cape Colony . . 1825-1828

Equal Rights ordinance in favour of the Natives . . . . 1828

Emancipation of the Slaves . . . . . . . . . 1834

Sixth Kafir War . . . . . . . . . . . . . . . . 1834

Emigration of the discontented Boers (the Great Trek) . I 836-7

Conquest of Matabililand by Mosilikatze . . . . . . . . 1837

The emigrant Boers occupy Natal . . . . . . . . 1838

British occupation and annexation of Natal . . . . . 1843

Two native "buffer States" created in the interior . . . 1843

Seventh Kafir War ; province' of British Kaffraria created 1847

Orange River Sovereignty created . . . . . . . . 1848

Recognition of the Independence of the Transvaal Boers

(Sand River Convention) . . . . . . . . . . 1852

Recognition of the Independence of the Orange River

Boers (Bloemfontein Convention) . . . . . . . 1854

Representative Government established in Cape Colony . I854 
Establishment of a Constitution for the South African A. D.

Republic . . . . . . . . . . . . 1855-1 858

Proclamation of a Protectorate over Basutoland . . . 1868

Discovery of diamonds on the Lower Vaal River . . . . 1869

British occupation and annexation of Griqualand West . I87I

Responsible Government granted to Cape Colony . . . . 1872

Delagoa Bay arbitration . . . . . . . . . . . . I872-1875

British annexation of the Transvaal . . . . . . . I 1877

War with Cetewayo and conquest of Zululand . . . . . 1879

Retrocession of the Transvaal . . . . . . . . . . I88I

Annexation of Southern and Protectorate over Northern

Bechuanaland . . . . . . . . . . . . . 1884-1 885

German occupation of Damaraland . . . . . . . . . I884

Convention of London with the Transvaal Republic . . . I884

Discovery of the Witwatersrand gold field] . . . . . . 1885

Foundation of the British South Africa Company . . . . 1889

Conquest of Matabililand by the Company . . . . . . . I893

Responsible Government granted to Natal . . . . . . . 1893

Protectorate declared over the Tonga Chiefs . . . . . . 1894

Rising at Johannesburg and expedition from Pitsani . . 1895 


\section{INTRODUCTION}

IN the latter part of the year I895 I travelled across South Africa from Cape Town to Fort Salisbury in Mashonaland, passing through Bechuanaland and Matabililand. From Fort Salisbury, which is only two hundred miles from the Zambesi, I returned through Manicaland and the Portuguese territories to Beira on the Indian Ocean, sailed thence to Delagoa Bay and Durban, traversed Natal, and visited the Transvaal, the Orange Free State, Basutoland, and the eastern province of Cape Colony. The country had long possessed a great interest for me, and that interest was increased by studying on the spot its physical character as well as the peculiar economic and industrial conditions which have made it unlike the other newly settled countries of the world. Seeing these things and talking with the leading men in every part of the country, I began to comprehend many things that had previously been obscure to me, and saw how the political troubles of the land were connected with the life which nature imposed on the people. Im- 
mediately after my return to Europe, fresh political troubles broke out, and events occurred in the Transvaal which fixed the eyes of the whole world upon South Africa. I had not travelled with the view of writing a book; but the interest which the events just mentioned have aroused, and which is likely to be sustained for a good while to come, leads me to believe that the impressions of a traveller who has visited other new countries may be useful to those who desire to know what South Africa is really like, and why it makes a noise and stir in the world disproportionate to its small population.

I have called the book "Impressions" lest it should be supposed that I have attempted to present a complete and minute account of the country. For this a long residence and a large volume would be required. It is the salient features that I wish to describe. These, after all, are what most readers desire to know: these are what the traveller of a few weeks or months can give, and can give all the better because the details have not become so familiar to him as to obscure the broad outlines.

Instead of narrating my journey, and weaving into the narrative observations on the country and people, I have tried to arrange the materials collected in a way better fitted to present to the reader in their natural connection the facts he will desire to have. Those facts would seem to be the following: 
(I) the physical character of the country, and the aspects of its scenery; (2) the characteristics of the native races that inhabit it; (3) the history of the natives and of the European settlers, that is to say, the chief events which have made the people what they now are ; $(4)$ the present condition of the several divisions of the country, and the aspects of life in it ; (5) the economic resources of the country, and the characteristic features of its society and its politics.

These I have tried to set forth in the order above indicated. The first seven chapters contain a very brief account of the physical structure and climate, since these are the conditions which have chiefly determined the economic progress of the country and the lines of European migration, together with remarks on the wild animals, the vegetation, and the scenery. Next follows a sketch of the three aboriginal races, and an outline of the history of the whites since their first arrival, four centuries ago. The earlier events are lightly touched on, while those which have brought about the present political situation are more fully related. In the third part of the book, asking the reader to accompany me on the long journey from Cape Town to the Zambesi Valley and back again, I have given in four chapters a description of the far interior as one sees it passing from barbarism to civilization-its scenery, the prospects of its material development, the life which its 
new settlers lead. These regions, being the part of the country most lately brought under European administration, seem to deserve a fuller treatment than the older and better-known regions. Three other chapters give a more summary account of Natal, of the Transvaal gold-fields, of that model republic the Orange Free State, and of Basutoland, a native state under British protection which possesses many features of peculiar interest. In the fourth and last division of the book several questions of a more general character are dealt with which could not conveniently be brought into either the historical or the descriptive parts. I have selected for discussion those topics which are of most permanent importance and as to which the reader is most likely to be curious. Among them are the condition of the natives, and their relations to the white people; the aspects of social and political life; the situation of affairs in the Transvaal in 1895 , and the causes which brought about the Reform rising and the expedition of Dr. Jameson; and finally, the economic prospects of the country, and he political future of its colonies and republics.

In these concluding chapters, as well as in the historical sketch, my aim has been to set forth and explain facts rather than to pass judgments upon the character and conduct of individuals. Whoever desires to help others to a fair view of current events must try not only to be impartial, but also to 
avoid expressing opinions when the grounds for those opinions cannot be fully stated; and where controversy is raging round the events to be described, no judgment passed on individual actors could fail to be deemed partial by one set of partizans or by the other. Feeling sure that the present problems will take some time to solve, I have sought to write what those who desire to understand the country may find useful even after the next few years have passed. And, so far from wishing to champion any view or to throw any fresh logs on the fire of controversy that has been blazing for the last two years, I am convinced that the thing now most needed in the interests of South Africa is to let controversies die out, to endeavour to forget the causes of irritation, and to look at the actual facts of the case in a purely practical spirit.

Altogether apart from its recent troubles, South Africa is an interesting, and indeed fascinating, subject of study. There are, of course, some things which one cannot expect to find in it. There has not yet been time to evolve institutions either novel or specially instructive, nor to produce new types of character (save that of the Transvaal Boer) or new forms of social life. There are no ancient buildings, except a few prehistoric ruins; nor have any schools of architecture or painting or literature been developed as yet. But besides the aspects of nature, often weird and sometimes beautiful, there are the 
savage races, whose usages and superstitions open a wide field for research, and the phenomena of whose contact with the whites raise some grave and gloomy problems. There are the relations of the two European races-races which ought long ago to have been happily blended into one, but which have been kept apart by a train of untoward events and administrative errors. Few of the newer countries have had a more peculiar or more chequered history ; and this history needs to be studied with a constant regard to the physical conditions that have moulded it. Coming down to our own time, nowhere are the struggles of the past seen to be more closely intertwined with the troubles of the present; nor does even Irish history furnish a better illustration of the effect of sentiment upon practical politics. Few events of recent times have presented more dramatic situations, and raised more curious and intricate issues of political and international morality, than those which have lately been set before us by the discovery of the Transvaal gold-fields and the rush of nineteenth-century miners and speculators into a pastoral population which retains the ideas and habits of the seventeenth - century. Still more fascinating are the problems of the future. One can as yet do little more than guess at them; but the world now moves so fast, and has grown so small, and sees nearly every part of itself so closely bound by ties of commerce or politics to every other 
part, that it is impossible to meditate on any great and new country without seeking to interpret its tendencies by the experience of other countries, and to conjecture the rôle it will be called on to play in the world-drama of the centuries to come. I have sought, therefore, not only to make South Africa real to those who do not know it, and to give them the materials for understanding what passes there and following its fortunes with intelligence, but also to convey an impression of the kind of interest it awakens. It is still new : and one sees still in a fluid state the substance that will soon crystallize into new forms. One speculates on the result which these mingled forces, these ethnic habits and historical traditions and economic conditions, will work out. And reflecting on all these things, one feels sure that a country with so commanding a position, and which has compressed so much history into the last eighty years of its life, will hold a conspicuous place in that southern hemisphere which has in our own times entered into the political and industrial life of the civilized world. 

PART I

$N A T U R E$

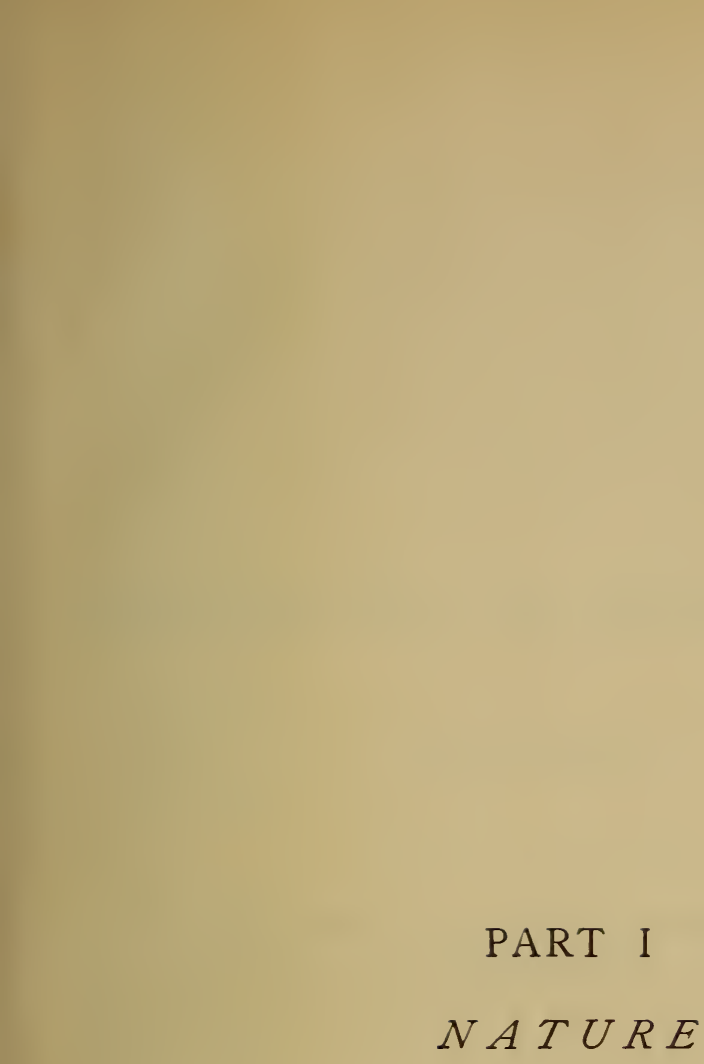

\section{$A T U R E$}





\title{
IMPRESSIONS OF SOUTH AFRICA
}

\author{
CHAPTER I \\ PHYSICAL FEATURES
}

To understand the material resources and economic conditions of South Africa, and, indeed, to understand the history of the country and the political problems which it now presents, one must first know something of its physical structure. The subject may seem dry, and those readers who do not care for it may skip this chapter. But it need not be uninteresting, and it is certainly not uninstructive. For myself, I can say that not only South African history, but also the prospects of South African industry and trade, were dark matters to me till I had got, by travelling through the country, an idea of those natural features of the southern part of the continent which have so largely governed the course of events and have stamped themselves so deeply upon the habits of the people. Some notion of these features I must now try to convey. Fortunately, they are simple, for nature has worked in Africa, as 
CHAP.

in America, upon larger and broader lines than she has done in Europe. The reader will do well to keep a map beside him, and refer ${ }^{1}$ constantly to it, for descriptions without a map avail little.

Africa south of the Zambesi River consists, speaking broadly, of three regions. There is a strip of lowland lying along the coast of the Indian Ocean, all the way round from Cape Town, past Durban and Delagoa Bay and Beira, till you reach the mouth of the Zambesi. On the south, between Cape Town and Durban, this strip is often very narrow, for in many places the hills come, as they do at Cape Town, right down to the sea. But beyond Durban, as one follows the coast along to the north-east, the level strip widens. At Delagoa Bay it is some fifteen or twenty miles wide; at Beira it is sixty or eighty miles wide, so that the hills behind cannot be seen from the coast; and farther north it is still wider. This low strip is in many places wet and swampy, and, being swampy, is from Durban northward malarious and unhealthful in the highest degree. Its unhealthfulness is a factor of prime importance in what may be called the general scheme of the country, and has had, as we shall presently see, the most important historical consequences.

Behind the low coast strip rise the hills whose slopes constitute the second region. They rise in most places rather gradually, and they seldom (ex-

1 In particular, I will ask the reader to refer to the two maps showing the physical features of the country which have been inserted in this volume. 
cept in Manicaland, to be hereafter described) present striking forms. The neighbourhood of Cape Town is almost the only place where high mountains come close to the shore-the only place, therefore, except the harbour of St. John's, far to the east, where there is anything that can be called grand coast scenery. As one travels inland the hills become constantly higher, till at a distance of thirty or forty miles from the sea they have reached an average height of from 3000 to 4000 feet, and sixty miles from 5000 to 6000 feet. These hills, intersected by valleys which grow narrower and have steeper sides the farther inland one goes, are the spurs or outer declivity of a long range of mountains which runs all the way from Cape Town to the Zambesi Valley, a distance of sixteen hundred miles, and is now usually called by geographers (for it has really no general name) the Drakensberg or Quathlamba Range. Their height varies from 3000 to 7000 feet, some of the highest lying not far to the north-east of Cape Town. In one region, however, several summits reach to I I,000 feet. This is Basutoland, the country that lies at the corner where Cape Colony, Natal, and the Orange Free State meet. It is a region remarkable in several respects, for its scenery as well as for its history, and for the condition of the native race that inhabits it, and I shall have to give some account of it in a later chapter. These mountains of Basutoland are the loftiest in Africa south of Kilimandjaro, and keep snow on their summits for several months in the year. 
CHAP.

Behind the Quathlamba Range the country spreads out to the north and west in a vast tableland, sometimes flat, sometimes undulating, sometimes intersected by ridges of rocky hills. This is the third region. Its average height above the sea varies from 3000 to 5000 feet, and the hills reach in places nearly 6000. Thus the Quathlamba Range may be regarded as being really the edge of the tableland, and when in travelling up from the coast one reaches the water-shed, or "divide" (an American term which South Africans have adopted), one finds that on the farther or northerly side there is very little descent. The peaks which when seen from the slopes toward the coast looked high and steep are on this inner side insignificant, because they rise so little above the general level of the plateau. This plateau runs away inland to the west and north-west, and occupies seven eighths of the surface of South Africa. It dips gently on the north to the valley of the Zambesi ; but on the west spreads out over the Kalahari Desert and the scarcely less arid wastes of Damaraland, maintaining (except along the lower course of the Orange River) an altitude of from 3000 to 4000 feet above the sea, until within a comparatively short distance of the Atlantic Ocean.

The physical structure of the country is thus extremely simple. There is only one considerable mountain-chain, with a vast table-land filling the interior behind it, and a rough, hilly country lying between the mountains and the low belt which 
borders on the Indian Ocean. Let the reader suppose himself to be a traveller wishing to cross the continent from east to west. Starting from a port, say Delagoa Bay or Beira, on the Portuguese coast, the traveller will in a few hours, by either of the railways which run westward from those ports, traverse the low strip which divides them from the hill-country. To ascend the valleys and cross the water-shed of the great Quathlamba Range on to the plateau takes a little longer, yet no great time. Then, once upon the plateau, the traveller may proceed steadily to the west for more than a thousand miles over an enormous stretch of high but nearly level land, meeting no considerable eminence and crossing no perceptible water-shed till he comes within sight of the waves of the Atlantic. Or if he turns to the north-west he will pass over an undulating country, diversified only by low hills, till he dips slowly into the flat and swampy ground which surrounds Lake Ngami, itself rather a huge swamp than a lake, and descends very gradually from that level to the banks of the Zambesi, in the neighbourhood of the great Victoria Falls. In fact, this great plateau is South Africa, and all the rest of the country along the sea-margin a mere appendage to it. But so large a part of the plateau is, as we shall see presently, condemned by its dryness to remain sterile and very thinly peopled, that the interior has not that preponderating importance which its immense area might seem to give it.

It is not worth while to describe the minor ridges, 
-though some of them, especially in Cape Colony, are abrupt and high enough to be called Mountains,- - for none has any great importance as affecting either material or historical conditions. The longest are those which run parallel to the dreary and almost uninhabited west coast, and form the terraces by which the great plateau sinks down to the margin of the Atlantic. Neither can I touch on the geology, except to observe that a great part of the plateau, especially in the northern part and toward the north-east end of the Quathlamba Range, consists of granite or gneiss, and is believed to be of very great antiquity, i.e., to have stood, as it now stands, high above the level of the sea from a very remote period of the earth's history. The rocks of the Karroo region are more recent. Nowhere in South Africa has any area of modern volcanic action, much less any active volcano, been discovered. More ancient eruptive rocks, such as greenstones and porphyries, are of frequent occurrence, and are often spread out in level sheets above the sedimentary beds of the Karroo and of the Basutoland and Free State ranges.

Finally, it must be noted that the coast has extremely few harbours. From Cape Town eastward and north-eastward there is no sheltered deep water haven till one reaches that of Durban, itself troubled by a bar, and from Durban to the Zambesi no good ports save Delagoa Bay and Beira. On the other side of the continent, Saldanha Bay, twenty miles north of Cape Town, is an excellent 
harbour. After that the Atlantic coast shows none for a thousand miles.

So much for the surface and configuration of the country. Now let us come to the climate, which is a not less important element in making South Africa what it is.

The heat is, of course, great, though less great than a traveller from North Africa or India expects from the latitude. Owing to the vast mass of water in the southern hemisphere, that hemisphere is cooler in the same latitude than is the northern. Cape Town, in latitude $34^{\circ} \mathrm{S}$., has a colder winter and not so hot a summer as Gibraltar and Aleppo, in latitude $36^{\circ} \mathrm{N}$. Still the summer temperature is high even at Durban, in latitude $30^{\circ} \mathrm{S}$, while the northern part of the Transvaal Republic, and all the territories of the British South Africa Company, including Matabililand and Mashonaland, lie within the tropic of Capricorn, that is to say, correspond in latitude to Nubia and the central provinces of India between Bombay and Calcutta.

The climate is also, over most of the country, extremely dry. Except in a small district round Cape Town, at the southern extremity of the continent, there is no proper summer and winter, but only a dry season, the seven or eight months when the weather is colder, and a wet season, the four or five months when the sun is highest. Nor are the rains that fall in the wet season so copious and continuous as they are in some other hot countries; in many parts of India, for instance, or 
CHAP.

in the West Indies and Brazil. Thus even in the regions where the rainfall is heaviest, reaching thirty inches or more in the year, the land soon dries up and remains parched till the next wet season comes. The air is therefore extremely dry, and, being dry, it is clear and stimulating in a high degree.

Now let us note the influence upon the climate of that physical structure we have just been considering. The prevailing wind, and the wind that brings most of the rain in the wet season, is the east or south-east. It gives a fair supply of moisture to the low coast strip which has been referred to above. Passing farther inland, it impinges upon the hills which run down from the Quathlamba Range, waters them, and sometimes falls in snow on the loftiest peaks. A certain part of the rain-bearing clouds passes still farther inland, and scatters showers over the eastern part of the tableland, that is to say, over the Transvaal, the Orange Free State, eastern Bechuanaland, and the territories still farther north, toward the Zambesi. Very little humidity, however, reaches the tracts farther to the west. The northern part of Cape Colony as far as the Orange River, the western part of Bechuanaland, and the wide expanse of Damaraland have a quite trifling rainfall, ranging from four or five to ten inches in the whole year. Under the intense heat of the sun this moisture soon vanishes, the surface bakes hard, and the vegetation withers. All this region is therefore parched and arid, much of it, in fact, a desert, and likely always to remain so. 
These great and dominant physical facts-a low coast belt, a high interior plateau, a lofty, rugged mountain-range running nearly parallel to, and not very far from, the shore of the ocean, whence the rain-clouds come, a strong sun, a dry climate-have determined the character of South Africa in many ways. They explain the very remarkable fact that South Africa has, broadly speaking, no rivers. Rivers are, indeed, marked on the map-rivers of great length and with many tributaries; but when in travelling during the dry season you come to them you find either a waterless bed or a mere line of green and perhaps unsavoury pools. The streams that run south and east from the mountains to the coast are short and rapid torrents after a storm, but at other times dwindle to feeble trickles of mud. In the interior there are, to be sure, rivers which, like the Orange River or the Limpopo, have courses hundreds of miles in length. But they contain so little water during three fourths of the year as to be unserviceable for navigation, while most of their tributaries shrink in the dry season to a chain of pools, scarcely supplying drink to the cattle on their banks. This is one of the reasons why the country remained so long unexplored. People could not penetrate it by following waterways, as happened both in North and in South America; they were obliged to travel by ox-waggon, making only some twelve or sixteen miles a day, and finding themselves obliged to halt, when a good bit of grass was reached, to rest and restore the strength of their 
cattle. For the same reason the country is now forced to depend entirely upon railways for internal communication. There is not a stream (except tidal streams) fit to float anything drawing three feet of water.

It is a curious experience to travel for hundreds of miles, as one may do in the dry season in the north-eastern part of Cape Colony and in Bechuanaland, through a country which is inhabited, and covered in some places with wood, in others with grass or shrublets fit for cattle, and see not a drop of running water, and hardly even a stagnant pond. It is scarcely less strange that such rivers as there are should be useless for navigation. But the cause is to be found in the two facts already stated. In those parts where rain falls it comes at one season, within three or four months. Moreover, it comes then in such heavy storms that for some hours, or even days, the streams are so swollen as to be not only impassable by waggons, but also unnavigable, because, although there is plenty of water, the current is too violent. Then when the floods have ceased the streams fall so fast, and the channel becomes so shallow, that hardly even a canoe will float. The other fact arises from the proximity to the east coast of the great Quathlamba chain of mountains. The rivers that flow from it have mostly short courses, while the few that come down from behind and break through it, as does the Limpopo, are interrupted at the place where they break through by rapids which no boat can ascend. 


\section{CHAPTER II}

\section{HEALTH}

THE physical conditions just described determine the healthfulness of the country, and this is a matter of so much moment, especially to those who think of settling in South Africa, that I take the earliest opportunity of referring to it.

The sun-heat would make climate very trying to Europeans, and of course more trying the farther north toward the Equator they live, were it not for the two redeeming points I have dwelt on-the elevation and the dryness of the interior. To be 3000 , 4000 , or 5000 feet above the sea is for most purposes the same thing as being in a more temperate latitude, and more than five sixths in area of the districts which are now inhabited by Europeans have an elevation of fully 3000 feet. Not merely the tablelands of the Orange Free State and the Transvaal, but also by far the larger part of Cape Colony and nearly the whole of Natal (excluding a small strip along the coast), attain this elevation. Thus even in summer, when the heat is great during the day, the coolness of the night refreshes the system. The practical test of night temperature is whether 
CH.AP.

one wishes for a blanket to sleep under. In Madras and Bombay all the year round, in New York through several months of summer, in Paris or sometimes even in London for a few days in July or August, a light blanket is oppressive, and the continuance of the high day temperature through the hours of darkness exhausts and enfeebles all but vigorous constitutions. But in South Africa it is only along the coast, in places like Durban, Delagoa Bay, or Beira, that one feels inclined to dispense with a woollen covering at night, while in Johannesburg or Bloemfontein a good thick blanket is none too much even in November, before the cooling rains begin, or in December, when the days are longest. In fact, the fall of temperature at sunset is often a source of risk to those who, coming straight from Europe, have not yet learned to guard against sudden changes, for it causes chills, which, if they find a weak organ to pounce upon, may produce serious illness. These rapid variations of temperature are not confined to the passage from day to night. Sometimes in the midst of a run of the usual warm, brilliant weather of the dry season there will come a cold, bitter south-east wind, covering the sky with gray clouds and driving the traveller to put on every wrap he possesses. I remember, toward the end of October, such a sudden "cold snap" in Matabililand, only twenty degrees from the equator. One shivered all day long under a thick greatcoat, and the natives lit fires in front of their huts and huddled round them for warmth. Chills dangerous 
to delicate people are apt to be produced by these changes, and they often turn into feverish attacks, not malarial, though liable to be confounded with malarial fevers. This risk of encountering cold weather is a concomitant of that power of the south-east wind to keep down the great heats, which, on the whole, makes greatly for the salubrity of the country; so the gain exceeds the loss. But new comers have to be on their guard, and travellers will do well, even between the tropic and the equator, to provide themselves with warm clothing.

Strong as the sun is, its direct rays seem to be much less dangerous than in India or the eastern United States. Sunstroke is unusual,and one sees few people wearing, even in the tropical north, those hats of thick double felt or those sun-helmets which are deemed indispensable in India. In fact, Europeans go about with the same head-gear which they use in an English summer. But the relation of sunstroke to climate is obscure. Why should it be extremely rare in California, when it is very common in New York in the same latitude? Why should it be almost unknown in the Hawaiian Islands, within seventeen degrees of the equator? Its rarity in South Africa is a great point in favour of the healthfulness of the country, and also of the ease and pleasantness of life. In India one has to be always mounting guard against the sun. $\mathrm{He}$ is a formidable and ever-present enemy, and he is the more dangerous the longer you live in the country. In South Africa it is only because he dries up the 
soil so terribly that the traveller wishes to have less of him. The born Africander seems to love him.

The dryness of the climate makes very strongly for its salubrity. It is the absence of moisture no less than the elevation above sea-level that gives to the air its fresh, keen, bracing quality, the quality which enables one to support the sun-heat, which keeps the physical frame in vigour, which helps children to grow up active and healthy, which confines to comparatively few districts that deadliest foe of Europeans, swamp-fever. Malarial fever in one of its many forms, some of them intermittent, others remittent, is the scourge of the east coast as well as of the west coast. To find some means of avoiding it would be to double the value of Africa to the European powers which have been establishing themselves on the coasts. No one who lives within thirty miles of the sea nearly all the way south from Cape Guardafui to Zululand can hope to escape it. It is frequent all round the great Nyanza lakes, and particularly severe in the valley of the Nile from the lakes downward to Khartum. It prevails through the comparatively low country which lies along the Congo and the chief tributaries of that great stream. It hangs like a death-cloud over the valley of the Zambesi, and is found up to a height of 3000 or 4000 feet, sometimes even higher, in Nyassaland and the lower parts of the British territories that stretch to Lake Tanganyika. The Administrator of German East Africa has lately declared that there is not a square mile of that vast region that can be 
deemed free from it. Even along the generally arid shores of Damaraland there are spots where it is to be feared. But Cape Colony and Natal and the Orange Free State are almost exempt from it. So, too, are all the higher parts of the Transvaal, of Bechuanaland, of Matabililand, and of Mashonaland. Roughly speaking, one may say that the upper boundary line of malarial fevers in these countries is about 4500 feet above the sea, and where fevers occur at a height above 3000 feet they are seldom of a virulent type. Thus, while the lower parts of the Transvaal between the Quathlamba Mountains and the sea are terribly unhealthy, while the Portuguese country behind Delagoa Bay and Beira as far as the foot of the hills is equally dangerous,-Beira itself has the benefit of a strong sea-breeze,-by far the larger part of the recently occupied British territories north and west of the Transvaal is practically safe. It is, of course, proper to take certain precautions, to avoid chills and the copious use of alcohol, and it is specially important to observe such precautions during and immediately after the wet season, when the sun is raising vapours from the moist soil, when new vegetation has sprung up, and when the long grass which has grown during the first rains is rotting under the later rains. Places which are quite healthful in the dry weather, such as Gaberones and the rest of the upper valley of the rivers Notwani and Limpopo in eastern Bechuanaland, then become dangerous, because they lie on the banks of streams which inundate the lower 
grounds. Much depends on the local circumstances of each spot. To illustrate the differences between one place and another, I may take the case of the three chief posts in the territories of the British South Africa Company. Buluwayo, nearly 4000 feet above the sea, is always practically free from malaria, for it stands in a dry, breezy upland with few trees and short grass. Fort Victoria, 3670 feet above the sea, is salubrious enough during the dry season, but often feverish after the rains, because there is some wet ground near it. Fort Salisbury, 4900 feet above the sea, is now healthful at all times, but parts of it used to be feverish at the end of the rainy season, until they were drained in the beginning of I895. So Pretoria, the capital of the Transvaal Republic, is apt to be malarious during the months of rain, because (although 4470 feet above the sea) it lies in a well-watered hollow, while at Johannesburg, thirty miles off, on the top of a high, bare, stony ridge, one has no occasion to fear fever, though the want of water and proper drainage, as well as the quantity of fine dust from the highiy comminuted ore and "tailings" with which the air is filled, had until 1896 given rise to other maladies, and especially to septic pneumonia. These will diminish with a better municipal administration, and similarly malaria will doubtless vanish from the many spots where it is now rife when the swampy grounds have been drained and the long grass eaten down by larger herds of cattle.

It is apparently the dryness and the purity of the 
air which have given South Africa its comparative immunity from most forms of chest disease. Many sufferers from consumption, for whom a speedy death, if they remained in Europe, has been predicted, recover health, and retain it till old age. The spots chiefly recommended are on the high grounds of the interior plateau, where the atmosphere is least humid. Ceres, ninety-four miles by rail from Cape Town, and Beaufort West, in the Karroo, have been resorted to as sanatoria; and Kimberley, the city of diamonds, has an equally high reputation for the quality of its air. However, some of the coast districts are scarcely less eligible, though Cape Town has too many rapid changes of weather, and Durban too sultry a summer, to make either of them a desirable place of residence for invalids.

Apart from all questions of specific complaints, there can be no doubt as to the general effect of the climate upon health. The aspect of the people soon convinces a visitor that, in spite of its heat, the country is well fitted to maintain in vigour a race drawn from the cooler parts of Europe. Comparatively few adult Englishmen sprung from fathers themselves born in Africa are as yet to be found. But the descendants of the Dutch and Huguenot settlers are Africanders up to the sixth or seventh generation, and the stock shows no sign of losing either its stature or its physical strength. Athletic sports are pursued as eagerly as in England. 


\section{CHAPTER III}

WILD ANIMALS AND THEIR FATE

When first explored, South Africa was unusually rich in the kinds both of plants and of animals which it contained; and until forty or fifty years ago the number, size, and beauty of its wild creatures were the things by which it was chiefly known to Europeans, who had little suspicion of its mineral wealth, and little foreboding of the trouble that wealth would cause. Why it was so rich in species is a question on which geology will one day be able to throw light, for much may depend on the relations of land and sea in earlier epochs of the earth's history. Probably the great diversities of elevation and of climate which exist in the southern part of the continent have contributed to this profuse variety; and the fact that the country was occupied only by savages, who did little or nothing to extinguish any species nature had planted, may have caused many weak species to survive when equally weak ones were perishing in Asia and Europe at the hands of more advanced races of mankind. The country was therefore the paradise of hunters. Besides the lion 
and the leopard, there were many other great cats, some of remarkable beauty. Besides the elephant, which was in some districts very abundant, there existed two kinds of rhinoceros, as well as the hippopotamus and the giraffe. There was a wonderful profusion of antelopes, - thirty-one species have been enumerated,--including such noble animals as the eland and koodoo, such beautiful ones as the springbok and klipspringer, such fierce ones as the blue wildebeest or gnu. There were two kinds of zebra, a quagga, and a buffalo, both huge and dangerous. Probably nowhere in the world could so great a variety of beautiful animals be seen or a larger variety of formidable ones be pursued.

All this has changed, and changed of late years with fatal speed, under the increasing range and accuracy of firearms, the increasing accessibility of the country to the European sportsman, and the increasing number of natives who possess guns. The Dutch Boer of eighty years ago was a good marksman and loved the chase, but he did not shoot for fame and in order to write about his exploits, while the professional hunter who shot to sell ivory or rare specimens had hardly begun to exist. The work of destruction has latterly gone on so fast that the effect of stating what is still left can hardly be to tempt others to join in that work, but may help to show how urgent is the duty of arresting the process of extermination.

When the first Dutchmen settled at the Cape the lion was so common as to be one of the every-day 
perils of life. Tradition points out a spot in the pleasure-ground attached to the Houses of Parliament at Cape Town where a lion was found prowling in what was then the commandant's garden. In I653 it was feared that lions would storm the fort to get at the sheep within it, and so late as 1694 they killed nine cows within sight of the present castle. To-day, however, if the lion is to be found at all within the limits of Cape Colony, it is only in the wilderness along the banks of the Orange River, He was abundant in the Orange Free State when it became independent in 1854 , but has been long extinct there. He survives in a few spots in the north of the Transvaal and in the wilder parts of Zululand and Bechuanaland, and is not unfrequent in Matabililand and Mashonaland. One may, however, pass through those countries, as I did in October, I895, without having a chance of seeing the beast or even hearing its nocturnal voice, and those who go hunting this grandest of all quarries are often disappointed. In the strip of flat land between the mountains and the Indian Ocean behind Sofala and Beira, and in the Zambesi valley, there remain lions enough; but the number diminishes so fast that even in that malarious and thinly peopled land none may be left thirty years hence.

The leopard is still to be found all over the country, except where the population is thickest ; and as the leopard haunts rocky places, it is, though much hunted for the sake of its beautiful skin, less likely to be exterminated. Some of the smaller 
carnivora, especially the pretty lynxes, have now become very rare. There is, however, a fairly good supply of hyenas.

Elephants used to roam in great herds over all the more woody districts, but have now been quite driven out of Cape Colony, Natal, and the two Dutch republics, save that in a narrow strip of forest country near the south coast, between Mossel Bay and Algoa Bay, some herds are preserved by the Cape government. So, too, in the north of the Transvaal there are still a few left, also specially preserved. It is only on the east coast south of the Zambesi, and here and there along that river, that the wild elephant can now be found. From these regions it will soon vanish, and unless something is done to stop the hunting of elephants the total extinction of the animal in Africa may be expected within another half-century; for the foolish passion for slaughter which sends so-called sportsmen on his track, and the high price of ivory, are lessening its numbers day by day. A similar fate awaits the rhinoceros, once common even near the Cape, where he overturned one day the coach of a Dutch governor. The white kind, which is the larger, is now all but extinct, while the black rhinoceros has become scarce even in the northern regions between the Limpopo and the Zambesi. The hippopotamus, protected by his aquatic habits, has fared better, and may still be seen plunging and splashing in the waters of the Pungwe, the Limpopo, and other rivers in Portuguese East Africa. But 
Natal will soon know this great amphibian no more, and within Cape Colony, where the creature was once abundant even in the swamps that bordered Table Bay, he is now to be found only in the pools along the lower course of the Orange River. The crocodile holds his ground better, and is still a serious danger to oxen who go down to drink at the streams. In Zululand and all along the east coast, as well as in the streams of Mashonaland and Matabililand, there is hardly a pool which does not contain some of these formidable saurians. Even when the water shrinks in the dry season till little but mud seems to be left, the crocodile, getting deep into the mud, maintains a torpid life till the rains bring him back into activity. Lo Bengula sometimes cast those who had displeased him, bound hand and foot, into a river to be devoured by these monsters, which he did not permit to be destroyed, probably because they were sacred to some tribes.

The giraffe has become very scarce, though a herd or two are left in the south of Matabililand, and a larger number in the Kalahari Desert. So, also, the zebra and many of the species of antelopes, especially the larger kinds, like the eland and the sable, are disappearing, while the buffalo is now only to be seen (except in a part of the Colony where a herd is preserved) in the Portuguese territories along the Zambesi and the east coast. The recent cattle-plague has fallen heavily upon him. So the ostrich would probably now remain only in the wilds of the Kalahari had not large farms been 
created in Cape Colony, where young broods are reared for the sake of the feathers. On these farms, especially near Graham's Town and in the Oudtshorn district, one may see great numbers; nor is there a prettier sight than that of two parent birds running along, with a numerous progeny of little ones around them. Though in a sense domesticated, they are often dangerous, for they kick forward and claw downward with great violence, and the person whom they knock down and begin to trample on has little chance of escape with his life. Fortunately, it is easy to drive them off with a stick or even an umbrella; and we were warned not to cross an ostrich-farm without some such defence.

Snakes, though there are many venomous species, seem to be less feared than in India or the wilder parts of Australia. The python grows to twenty feet or more, but is, of course, not poisonous, and never assails man unless first molested. The black momba, which is nearly as large as a rattlesnake, is, however, a dangerous creature, being ready to attack man without provocation, and the bite may prove fatal in less than an hour. One sees many skins of this snake in the tropical parts of South Africa, and hears many thrilling tales of combats with them. They are no longer common in the more settled and temperate regions.

Although even in Cape Colony and the Dutch republics there is still more four-footed game to be had than anywhere in Europe, there remain only two regions where large animals can be killed in 
CHAP.

any considerable numbers. One of these is the Portuguese territory between Delagoa Bay and the Zambesi, together with the adjoining parts of the Transvaal, where the lower spurs of the Quathlamba Range descend to the plain. This district is very malarious during and after the rains, and most of it unhealthy at all seasons. The other region is the Kalahari Desert and the country north of it between Lake Ngami and the Upper Zambesi. The Kalahari is so waterless as to offer considerable difficulties to European hunters, and the country round Lake Ngami is swampy and feverish. So far the wild creatures have nature in their favour; yet the passion for killing is in many persons so strong that neither thirst nor fever deters them, and if the large game are to be saved, it will clearly be necessary to place them under legal protection. This has been attempted so far as regards the elephant, rhinoceros, giraffe, and eland. In German East Africa Dr. von Wissmann, the Administrator of that territory, has recently ( 1896 ) gone further, and ordained restrictions on the slaughter of all the larger animals, except predatory ones. The governments of the two British colonies and the two Boer republics, which have already done well in trying to preserve some of the rarest and finest beasts, ought to go thoroughly into the question and enact a complete protective code. Still more necessary is it that a similar course should be taken by the British South Africa Company and by the Imperial Government, in whose territories there still survive more of the great beasts. It is to be 
hoped that even the lion and some of the rare lynxes will ultimately receive consideration. Noxious as they are, it would be a pity to see them wholly exterminated. When I was in India, in the year I 888 , I was told that there were only seven lions then left in that vast area, all of them well cared for. The work of slaughter ought to be checked in South Africa before the number gets quite so low as this, and though there may be difficulties in restraining the natives from killing the big game, it must be remembered that as regards many animals it is the European, rather than the native, who is the chief agent of destruction.

The predatory creatures which are now most harmful to the farmer are the baboons, which infest rocky districts and kill the lambs in such great numbers that the Cape government offers bounties for their slaughter. But no large animal does mischief for a moment comparable to that of the two insect plagues which vex the eastern half of the country, the white ants and the locusts. Of these I shall have something to say later. 


\section{CHAPTER IV}

\section{VEGETATION}

THE flora of South Africa is extremely rich, showing a number of genera and of species which, in proportion to its area, exceeds the number found in most other parts of the world. But whether this wealth is due to the diversity of physical conditions which the country presents, or rather to geological causes, that is, to the fact that there may at some remote period have been land connections with other regions which have facilitated the immigration of plants from various sides, is a matter on which science cannot yet pronounce, for both the geology and the flora of the whole African continent have been very imperfectly examined. It is, however, worth remarking that there are marked affinities between the general character of the flora of the southwestern corner of South Africa and that of the flora of southwestern Australia, and similar affinities between the flora of southeastern and tropical Africa and the flora of India, while the relations to South America are fewer and much less marked. This fact would seem to point to the great antiquity of the South Atlantic Ocean. 
To give in such a book as this even the scantiest account of the plants of South Africa would obviously be impossible. All I propose is to convey some slight impression of the part which its vegetation, and particularly its trees, play in the landscape and in the economic conditions of the country. Even this I can do but imperfectly, because, like most travellers, I passed through large districts in the dry season, when three fourths of the herbaceous plants are out of flower.

No part of the country is richer in beautiful flowers than the immediate neighbourhood of Cape Town. This extreme southwestern corner of Africa has a climate of the south temperate zone; that is to say, it has a real summer and a real winter, and gets most of its rain in winter, whereas the rest of South Africa has only a wet season and a dry season, the latter coming in winter. So, too, this corner round Cape Town has a vegetation characteristically its own, and differing markedly from that of the arid Karroo regions to the north, and that of the warm subtropical regions in the east of the Colony and in Natal. It is here that the plants flourish which Europeans and Americans first came to know and which are still to them the most familiar examples of the South African flora. Heaths, for instance, of which there are said to be no less than three hundred and fifty species in this small district, some of extraordinary beauty and brilliance, are scarcely found outside of it. I saw two or three species on the high peaks of 
Basutoland, and believe some occur as far north as the tropic on the tops of the Quathlamba Range; but in the lower grounds, and even on the plateau of the Karroo, they are absent. The general aspect of the vegetation on the Karroo, and eastward over the plateau into Bechuanaland and the Transvaal, is to the traveller's eye monotonous - a fact due to the general uniformity of the geological formations and the general dryness of the surface. In Natal and in Mashonaland types different from those of either the Cape or the Karroo appear, and I have never seen a more beautiful and varied alpine flora than on a lofty summit of Basutoland which I ascended on November 23. But even in Mashonaland, and in Matabililand still more, the herbaceous plants make, at least in the dry season, comparatively little show. I found the number of conspicuous species less than I had expected, and the diversity of types from the types that prevail in the southern part of the plateau (in Bechuanaland and the Orange Free State) less marked. This is doubtless due to the general similarity of the conditions that prevail over the plateau. Everywhere the same hot days and cold nights, everywhere the same dryness.

However, I must avoid details, especially details which would be interesting only to a botanist, and be content with a few words on those more conspicuous features of the vegetation which the traveller notes, and which go to make up his general impression of the country. 
Speaking broadly, South Africa is a bare country, and this is the more remarkable because it is a new country, where man has not had time to work much destruction. There are ancient forests along the south coast of Cape Colony and Natal, the best of which are (in the former colony) now carefully preserved and administered by a Forest Department of Government. Such is the great Knysna forest, where elephants still roam wild. But even in these forests few trees exceed fifty or sixty feet in height, the tallest being the so-called yellow-wood, and the most useful the sneeze-wood. On the slopes of the hills above Graham's Town and King William's Town one finds (besides real forests here and there) immense masses of dense scrub, or "bush," usually from four to eight feet in height, sometimes with patches of the prickly-pear, an invader from America, and a formidable one; for its spines hurt the cattle and make passage by men a troublesome business. It was this dense, low scrub which constituted the great difficulty of British troops in the fierce and protracted Kafir wars of fifty years ago; for the ground which the scrub covers was impassable except by narrow and tortuous paths known only to the natives, and it afforded them admirable places for ambush and for retreat. Nowadays a large part of the bush-covered land is used for ostrich-farms, and it is, indeed, fit for little else. The scrub is mostly dry, while the larger forests are comparatively damp, and often beautiful with flowering trees, small tree-ferns, and flexile climbers. But the trees are 
not lofty enough to give any of that dignity which a European forest, say in England or Germany or Norway, often possesses, and as the native kinds are mostly evergreens, their leaves have comparatively little variety of tint. One of the most graceful is the curious silver-tree, so called from the whitish sheen of one side of its leaves, which grows abundantly on the slopes of Table Mountain, but is found hardly anywhere else in the Colony.

If this is the character of the woods within reach of the coast rains, much more conspicuous is the want of trees and the poorness of those scattered here and there on the great interior plateau. In the desert region, that is to say, the Karroo, the northern part of Cape Colony to the Orange River, western Bechuanaland, and the German territories of $\mathrm{Na}$ maqualand and Damaraland, there are hardly any trees, except small, thorny mimosas (they are really acacias, the commonest being Acacia horrida), whose scanty, light-green foliage casts little shade. On the higher mountains, where there is a little more moisture, a few other shrubs or small trees may be found, and sometimes beside a watercourse, where a stream runs during the rains, the eye is refreshed by a few slender willows; but speaking generally, this huge desert, one-third of South Africa, contains nothing but low bushes, few of which are fit even for fuel. Farther east, where the rainfall is heavier, the trees, though still small, are more frequent and less thorny. Parts of the great plain round Kimberley were tolerably well wooded 
thirty years ago, but the trees have all been cut down to make mine props or for fire-wood. North of Mafeking the rolling flats and low hills of Bechuanaland are pretty fairly wooded, and so to a less degree are the adjoining parts of the Transvaal and Matabililand. The road going north from Mafeking passes through some three hundred miles of such woodlands, but a less beautiful or interesting woodland I have never seen. The trees are mostly the thorny mimosas I have mentioned. None exceed thirty, few reach twenty-five, feet. Though they grow loosely scattered, the space between them is either bare or occupied by low and very prickly bushes. The ground is parched, and one can get no shade, except by standing close under a trunk somewhat thicker than its neighbours. Still farther north the timber is hardly larger, though the general aspect of the woods is improved by the more frequent occurrence of flowering trees, some sweetscented, with glossy leaves and small white flowers, some with gorgeous clusters of blossoms. Three are particularly handsome. One, usually called the Kafir-boom, has large flowers of a brilliant crimson. Another (Lonchocarpus speciosus ${ }^{1}$ ), for which no

1 I owe these names to the kindness of the authorities at the Royal Gardens at Kew, who have been good enough to look through fifty-four dried specimens which I collected and preserved as well as I could while travelling through Mashonaland and Basutoland. Eleven of these fifty-four were pronounced to be species new to science, a fact which shows how much remains to be done in the way of botanical exploration. 
CHAP.

English name seems to exist, shows lovely pendulous flowers of a bluish lilac, resembling in colour those of the wistaria. The third is an arboraceous St. John's wort (Hypericum Schimperi ${ }^{1}$ ), which I found growing in a valley of Manicaland, at a height of nearly 4000 feet above the sea. All three would be great ornaments to a south European shrubbery could they be induced to bear the climate, which, in the case of the two latter (for I hardly think the Kafirboom would suit a colder air), seems not impossible. In Manicaland, among the mountains which form the eastern edge of the plateau, the trees are taller, handsomer, and more tropical in their character, and palms, though of no great height, are sometimes seen. But not even in the most humid of the valleys and on the lower spurs of the range, where it sinks into the coast plain, nor along the swampy banks of the Pungwe River, did I see any tree more than sixty feet high, and few more than thirty. Neither was there any of that luxuriant undergrowth which makes some tropical forests, like those at the foot of the Nilghiri Hills in India or in some of the isles of the Pacific, so impressive as evidences of the power and ceaseless activity of nature.

The poverty of the woods in Bechuanaland and Matabililand seems to be due not merely to the dryness of the soil and to the thin and sandy character which so often marks it, but also to the constant grass-fires. The grass is generally short, so that these fires do not kill the trees ; nor does one hear

1 See note on p. 3 I. 
of such great forest conflagrations as are frequent and ruinous in Western America and by no means unknown in the south of Cape Colony. But these fires doubtless injure the younger trees sufficiently to stunt their growth, and this mischief is, of course, all the greater when an exceptionally dry year occurs. In such years the grass-fires, then most frequent, may destroy the promise of the wood over a vast area.

The want of forests in South Africa is one of the greatest misfortunes of the country, for it makes timber costly; it helps to reduce the rainfall, and it aggravates the tendency of the rain, when it comes, to run off rapidly in a sudden freshet. Forests have a powerful influence upon climate in holding moisture, ${ }^{1}$ and not only moisture but soil also. In South Africa the violent rain-storms sweep away the surface of the ground, and prevent the deposition of vegetable mould. Nothing retains that mould or the soil formed by decomposed rock as well as a covering of wood and the herbage which the neighborhood of comparatively moist woodlands helps to support. It is much to be desired that in all parts of the country where trees will grow trees should be planted, and that those which remain should be protected.

${ }^{1}$ It has been plausibly suggested that one reason why many English rivers which were navigable in the tenth century (because we know that the Northmen traversed them in vessels which had crossed the German Ocean) but are now too shallow to let a rowboat pass is to be found in the destruction of the forests and the draining of the marshes which the forests sheltered 
CHAP.

Unfortunately, most of the South African trees grow slowly, so where planting has been attempted it is chiefly foreign sorts that are tried. Among these the first place belongs to the Australian gums, because they shoot up faster than any others. One finds them now everywhere, mostly in rows or groups round a house or a hamlet, but sometimes also in regular plantations. They have become a conspicuous feature in the landscape of the veldt plateau, especially in those places where there was no wood, or the little that existed has been destroyed. Kimberley, for instance, and Pretoria are beginning to be embowered in groves of eucalyptus; Bulawayo is following suit; and all over Matabililand and Mashonaland one discovers in the distance the site of a farmsteading or a store by the waving tops of the gum-trees. If this goes on these Australian immigrants will sensibly affect the aspect of the country, just as already they have affected that of the Riviera in south-eastern France, of the Campagna of Rome, of the rolling tops of the Nilghiri Hills in Southern India, from which, unhappily, the far more beautiful ancient groves ("sholas") have now almost disappeared. Besides those gums, another Australasian tree, the thin-foliaged and unlovely, but quick growing "beefwood," has been largely planted at Kimberley and some other places. The stone-pine of Southern Europe, the cluster-pine (Pinus Pinaster), and the Aleppo or Jerusalem pine (Pinus Halepensis) have all been introduced and seem to do well. The Australian wattles have been 
found very useful in helping to fix the soil on sandy flats, such as those near Cape Town, and the bark of one species is an important article of commerce in Natal, where (near Maritzburg, for instance) it grows profusely. But of all the immigrant trees none is so beautiful as the oak. The Dutch began to plant it round Cape Town early in the eighteenth century, and it is now one of the elements which most contribute to the charm of the scenery in this eminently picturesque southwest corner of the country. Nothing can be more charming than the long oak avenues which line the streets of Stellenbosch, for instance ; and they help, with the old-fashioned Dutch houses of that quaint little town, to give a sort of Hobbema flavour to the foregrounds.

The changes which man has produced in the aspect of countries, by the trees he plants and the crops he sows, are a curious subject for inquiry to the geographer and the historian. These changes sometimes take place very rapidly. In the Hawaiian Islands, for instance, discovered by Captain Cook little more than a century ago, many of the shrubs which most abound and give its tone to the landscape have come (and that mostly not by planting but spontaneously) from the shores of Asia and America within the last eighty years. In Egypt most of the trees which fill the eye in the drive from Cairo to the Pyramids were introduced by Mehemet Ali, so that the banks of the Nile, as we see them, are different not only from those which Herodotus, but even from those which Napoleon saw. In North 
Africa the Central American prickly-pear and the Australian gum make the landscape quite different from that of Carthaginian or even of Roman times. So South Africa is changing-changing all the more because many of the immigrant trees thrive better than the indigenous ones, and are fit for spots where the latter make but little progress; and in another century the country may wear an aspect quite unlike that which it now presents. 


\section{CHAPTER V}

\section{PHYSICAL ASPECTS OF THE VARIOUS POLITICAL DIVISIONS}

Hitherto I have spoken of South Africa as a natural whole, ignoring its artificial division into Colonies and States. It may be well to complete the account of the physical characteristics of the country by giving the reader some notion of the aspects of each of the political divisions, and thereby a notion also of their relative importance and resources as wealth-producing regions.

\section{CAPE COLONY}

Cape Colony is a huge territory more than twice as large as the United Kingdom. But very little of it is available for tillage, and much of it is too arid even for stock-keeping. The population, including natives, is only seven to the square mile. Nearly the whole of it is high country. All along its westerly coast and its southerly coast there is a strip of low ground bordering the ocean, which in some places is but a mile or two wide, and in others, where a broad valley opens, spreads backward, 
CHAP.

giving thirty or forty square miles of tolerably level or undulating ground. The rich wine and corn district round Stellenbosch and Paarl and northward towards Malmesbury is such a tract. Behind this low strip the country rises, sometimes in steep acclivities, up which a road or railway has to be carried in curves and zigzags, sometimes in successive terraces, the steps, so to speak, by which the lofty interior breaks down towards the sea.

Behind these terraces and slopes lies the great table-land described in a preceding chapter. Though I call it a table-land, it is by no means flat, for several long, though not lofty, ranges of hills, mostly running east and west, intersect it. Some tracts are only 2,000 feet, others as much as 5,000 feet, above the sea, while the highest hilltops approach 8,000 feet. The part of this high country which lies between longitude $20^{\circ}$ and $25^{\circ} \mathrm{E}$., with the Nieuweld and Sneeuwberg mountains to the north of it, and the $Z$ warte Berg to the south, is called the Great Karroo. (The word is Hottentot, and means a dry or bare place.) It is tolerably level, excessively dry, with no such thing as a running stream over its huge expanse of three hundred miles long and half as much wide, nor, indeed, any moisture, save in a few places shallow pools which almost disappear in the dry season. The rainfall ranges from five to fifteen inches in the year. It is therefore virtually a desert, bearing no herbage (except for a week or two after a rainstorm), and no trees, though there are plenty of prickly shrubs and small bushes, some of these 
succulent enough, when they sprout after the few showers that fall in the summer, to give good browsing to sheep and goats. The brilliancy of the air, the warmth of the days, and the coldness of the nights remind one who traverses the Karroo of the deserts of Western America between the Rocky Mountains and the Sierra Nevada, though the soil is much less alkaline, and the so-called "sage-brush" plants characteristic of an alkaline district are mostly absent. To the north of the Karroo and of the mountains which bound it, a similar district, equally arid, dreary, and barren, stretches away to the banks of the Orange River, which here in its lower course has less water than in its upper course, because, like the Nile, it receives no affluents and is wasted by the terrible sun. In fact, one may say that from the mountains dividing the southern part of the Karroo from the coast lands all the way north to the Orange River, a distance of nearly four hundred miles, nature has made the country a desert of clay and stone (seldom of sand), though man has here and there tried to redeem it for habitation.

The north-eastern part of the interior of Cape Colony is more generally elevated than the southwestern. From Graaf-Reinet northward to Kimberley and Mafeking, and north-eastward to the borders of Basutoland, the country is 4,000 feet or more above sea-level ; much of it is nearly level, and almost all of it bare of wood. It is better watered than the western districts, enjoying a rainfall of from ten to twenty-five inches in the year, and therefore 
CHAP.

much of it is covered with grass after the rains, and not merely with dry thorny bushes. Nevertheless, its general aspect in the dry season is so parched and bare that the stranger is surprised to be told that it supports great quantities of cattle, sheep, and goats. The south-eastern part, including the Quathlamba Range, and the hilly country descending from that range to the sea, has a still heavier rainfall and is in some places covered with forest. Here the grass is richer, and in the valleys there is plenty of land fit for tillage without irrigation.

\section{THE COLONY OF NATAL}

Much smaller, but more favoured by nature, is the British colony of Natal, which adjoins the easternmost part of Cape Colony, while still farther east lies the British territory of Zululand. Both districts resemble in their physical conditions the southeastern corner of Cape Colony. Both lie entirely on the sea slope of the Quathlamba Range, and are covered by mountains and hills descending from that range. Both are hilly or undulating, with a charming variety of surface; and they are also comparatively well watered, with a perennial stream in every valley. Hence there is plenty of grass, and toward the coast plenty of wood also, while the loftier interior is bare. The climate is much warmer than that of Cape Colony, and in the little low strip which borders the sea becomes almost tropical. Nor is this heat attributable entirely to the latitude. It is 
largely due to the great Mozambique current, which brings down from the tropical parts of the Indian Ocean a vast body of warm water which heats the adjoining coast just as the Gulf Stream heats the shores of Georgia and the Carolinas; and the effect of this mass of hot water warming the air over it would doubtless be felt much more in Natal were it not for the rapid rise of the ground from the sea in that colony. Pietermaritzburg, the capital, is only some fifty miles from the coast as the crow flies. But though it lies in a valley, it is 2,225 feet above sea-level, and from it the country steadily rises inland, till at Laing's Nek (the watershed between the Indian Ocean and the Atlantic), the height of 5,300 feet is reached, and the winter cold is severe. Nearly the whole of Natal and fourfifths of Zululand may thus be deemed a temperate country, where Europeans can thrive and multiply. So far as soil goes it is one of the richest as well as one of the fairest parts of South Africa.

\section{GERMAN SOUTH-WEST AFRICA}

Very different is the vast German territory (322,000 square miles) which stretches northward from Cape Colony, bounded on the south by the Orange River, on the north by the West African territories of Portugal, on the east by Bechuanaland. Great Namaqualand and Damaraland constitute an enormous wilderness, very thinly peopled, because the means of life are very scanty. This wilderness 
is, except the narrow and sandy coast strip, a high country ( 3,000 to 4,500 feet above sea-level) and a dry country, drier even than the Karroo, and far too dry for any kind of cultivation. Some parts, especially those in the southwest, are hopelessly parched and barren; others have small bushes or grass; while on the higher grounds and generally in the far northern parts, where the Ovampo tribe dwell, grass is abundant, and as cattle can thrive there is also population. Copper has been discovered in considerable quantities, and other minerals (including coal) are believed to exist. But the country, taken all in all, and excepting the little-explored districts of the northeast, toward the Upper Zambesi,-districts whose resources are still very imperfectly known,-is a dreary and desolate region, which seems likely to prove of little value. Germany now owns the whole of it, save the port of Walfish Bay, which has been retained for and is administered by Cape Colony.

\section{PORTUGUESE SOUTH-EAST AFRICA}

On the opposite side of the continent Portugal holds the country which lies along the Indian Ocean from British Tongaland northward to the Zambesi. Close to the sea it is level, rising gently westward in hills, and in some places extending to the crest of the Quathlamba Mountains. Thus it has considerable variety of aspect and climate, and as the rain falls chiefly on the slopes of the mountains, the interior is generally better watered than the flat seaboard, 
which is often sandy and worthless. Much of this region is of great fertility, capable of producing all the fruits of the tropics. But much of it, including some of the most fertile parts, is also very malarious, while the heat is far too great for European labour. When plantations are established throughout it, as they have been in a few-but only a few-spots by the Portuguese, it will be by natives that they will be cultivated. The Kafir population is now comparatively small, but this may be due rather to the desolating native wars than to the conditions of the soil.

So much for the four maritime countries. There remain the two Dutch republics and the British territories which have not yet been formed into colonies.

\section{THE ORANGE FREE STATE}

The Orange Free State (48,000 square miles) lies entirely on the great plateau, between 4,000 and 5,000 feet above sea-level. It is in the main a level country, though hills are scattered over it, sometimes reaching a height of nearly 6,000 feet. A remarkable feature of most of these hills, as of many all over the plateau, is that they are flat-topped, and have often steep, even craggy escarpments. This seems due to the fact that the strata (chiefly sandstone) are horizontal; and very often a bed of hard igneous rock, some kind of trap or greenstone, or porphyry, protects the summit of the hill from the disintegrating influences of the weather. It is a bare land, with very little wood, and that small and 
scrubby, but is well covered with herbage, affording excellent pasture during two-thirds of the year. After the first rains, when these wide stretches of gently undulating land are dressed in their new vesture of brilliant green, nothing can be imagined more exhilarating than a ride across the wide expanse; for the air is pure, keen, and bracing, much like that of the high prairies of Colorado or Wyoming. There are fortunately no blizzards, but violent thunderstorms are not uncommon, and the hailstones-I have seen them as big as bantams' eggs-which fall during such storms sometimes kill the smaller animals, and even men. Dry as the land appears to the eye during the winter, the larger streams do not wholly fail, and water can generally be got. The south-eastern part of the Free State, especially along the Caledon River, is extremely fertile, one of the best corn-growing parts of Africa. The rest is fitter for pasture than for tillage, except, of course, on the alluvial banks of the rivers, and nearly the whole region is in fact occupied by huge grazing farms. As such a farm needs and supports only a few men, the population grows but slowly. The Free State is nearly as big as England and just as big as the State of New York; but it has only 77,000 white inhabitants and about 130,000 natives.

\section{THE SOUTH AFRICAN REPUBLIC}

Somewhat larger-about as large as Great Britain and nearly two-thirds the size of France-is the South African Republic, which we commonly talk of 
as the Transvaal. Of its white population, which numbers some 170,000 , two-thirds are in the small mining district of the Witwatersrand. All the Transvaal, except a strip on the eastern and another strip on the northern border along the river Limpopo, also belongs to the great plateau and exhibits the characteristic features of the plateau. The hills are, however, higher than in the Free State, and along the east, where the Quathlamba Range forms the outer edge of the plateau, they deserve to be called mountains, for some of them reach 7,000 feet. These high regions are healthy, for the summer heats are tempered by easterly breezes and copious summer rains. The lower parts lying toward the Indian Ocean and the Limpopo River are feverish, though drainage and cultivation may be expected to reduce the malaria and improve the conditions of health. Like the Free State, the Transvaal is primarily a pasture land, but in many parts the herbage is less juicy and wholesome than in the smaller republic, and belongs to what the Dutch Boers call "sour veldt." There are trees in the more sheltered parts, but except in the lower valleys, they are small, and of no economic value. The winter cold is severe, and the fierce sun dries up the soil, and makes the grass sear and brown for the greater part of the year. Strong winds sweep over the vast stretches of open upland, checked by no belts of forest. It is a country whose aspect has little to attract the settler. No one would think it worth fighting for so far as the surface goes; and 
until fourteen years ago nobody knew that there was enormous wealth lying below the surface.

\section{BRITISH TERRITORIES-BECHUANALAND}

Of one of the British territories outside the two colonies, viz., Zululand, I have already spoken; of another, Basutoland, I shall have to speak fully hereafter. A third, Bechuanaland, including the Kalahari Desert, is of vast extent, but slender value. It is a level land lying entirely on the plateau between 3,000 and 4,000 feet above the sea, and while some of its streamlets drain into the Limpopo, and so to the Indian Ocean, others flow westward and northward into marshes and shallow lakes, in which they disappear. One or two, however, succeed, in wet seasons, in getting as far as the Orange River, and find through it an outlet to the sea. It is only in the wet season that the streamlets flow, for Bechuanaland is intensely dry. I travelled four hundred miles through it without once crossing running water, though here and there in traversing the dry bed of a brook one was told that there was water underneath, deep in the sand. Notwithstanding this superficial aridity, eastern Bechuanaland is deemed one of the best ranching tracts in South Africa, for the grass is sweet, and the water can usually be obtained by digging, though it is often brackish. There is also plenty of wood-thin and thorny, but sufficiently abundant to diversify the aspect of what would otherwise be a most dreary and monotonous region. 
THE TERRITORIES OF THE BRITISH SOUTH AFRICA COMPANY

North of Bechuanaland and the Transvaal, and stretching all the way to the Zambesi, are those immense territories which have been assigned to the British South Africa Company as the sphere of its operations, and to which the name of Rhodesia has been given. Matabililand and Mashonaland, the only parts that have been at all settled, are higher, more undulating, and altogether more attractive than Bechuanaland, with great swelling downs somewhat resembling the steppes of Southern Russia or the prairies of Kansas. Except in the east and southeast, the land is undulating rather than hilly, but in the south-west, toward the Upper Limpopo, there lies a high region, full of small rocky heights often clothed with thick bush-a country difficult to traverse, as has been found during the recent native outbreak; for it was there that most of the Kaffirs took shelter and were found difficult to dislodge. Towards the south-east, along the middle course of the Limpopo, the country is lower and less healthy. On the northern side of the central highlands, the ground sinks towards the Zambesi, and the soil, which among the hills is thin or sandy, becomes deeper. In that part and along the river banks there are great possibilities of agricultural development, while the uplands, where the subjacent rock is granite or gneiss, with occasional beds of slate 
or schist, are generally barer and more dry, fit rather for pasture than for tillage. More rain falls than in Bechuanaland, so it is only at the end of the dry season, in October, that the grass begins to fail on the pastures. The climate, though very warm,- for here we are well within the tropics,--is pleasant and invigorating, for nowhere do brighter and fresher breezes blow, and the heat of the afternoons is forgotten in the cool evenings. It is healthy, too, except along the swampy river banks and where one descends to the levels of the Zambesi, or into the Limpopo Valley.

The reader will have gathered from this general sketch that there are no natural boundaries severing from one another the various political divisions of South Africa. The north-eastern part of Cape Colony is substantially the same kind of country as the Orange Free State and eastern Bechuanaland; the Transvaal, or at least three fourths of its area, is physically similar to the Free State; the boundary between Cape Colony and Natal is an artificial one; while Matabililand and Mashonaland present features resembling those of the Northern Transvaal, differing only in being rather hotter and rather better watered. So far as nature is concerned, the conditions she prescribes for the life of man, the resources she opens to his energies, are very similar over these wide areas, save, of course, that some parts are much richer than others in mineral deposits. It is only along the frontier line which divides Natal and the Portuguese dominions from the Transvaal and the territories of 
the British South Africa Company that a political coincides with a physical line of demarcation. Even German South-west Africa differs scarcely at all from the Kalahari Desert, which adjoins it and which forms the western part of Bechuanaland, and differs little also from the north-western regions of Cape Colony. If the reader will compare the two physical maps contained in this volume with the map which shows the political divisions of the country, he will notice that these political divisions do not correspond with the areas where more or less rain falls, or where the ground is more or less raised above the sea or traversed by mountain chains. The only exception is to be found in the fact that the boundary of Natal towards Basutoland and the Orange Free State has been drawn along the watershed between the Indian Ocean and the Atlantic, and that the boundary line between the Portuguese territories and those of the Transvaal Republic and of the British South Africa Company, is in many places the line of division between the mountains and the low country. The Orange River and the Limpopo have, in parts of their courses, been taken as convenient political frontiers. But rivers, though convenient for this purpose to the statesman and the geographer, are not natural boundaries in the true sense of the term. And thus we may say that the causes which have cut up South Africa into its present Colonies and States have been (except as aforesaid) historical causes, rather than differences due to the hand of nature. 


\section{CHAPTER VI}

NATURE AND HISTORY

Now that some general idea of how nature has shaped and moulded South Africa has been conveyed to the reader, a few pages may be devoted to considering what influence on the fortunes of the country and its inhabitants has been exerted by its physical character. The history of every country may be regarded as the joint result of three factors -the natural conditions of the country itself, the qualities of the races that have occupied it, and the circumstances under which their occupation took place. And among savage or barbarous people natural conditions have an even greater importance than they have in more advanced periods of civilisation, because they are more powerful as against man. Man in his savage state is not yet able to resist such conditions or to turn them to serve his purposes, but is condemned to submit to the kind of life which they prescribe.

This was the case with the first inhabitants of South Africa. They seem to have entered it as savages, and savages they remained. Nature was 
strong and stern; she spread before them no such rich alluvial plains as tempted cultivation in the valleys of the Nile and the Euphrates. Intellectually feeble, and without the patience or the foresight to attempt to till the soil in a land where droughts are frequent and disastrous, the Bushmen were content with killing game and the Hottentots with living on the milk of their cattle. Such a life, which was one of uncertainty and often of hardship, permitted no accumulation of wealth, gave no leisure, suggested no higher want than that of food, and was in all respects unfavourable to material progress. Even the Bantu people, who probably came later and were certainly more advanced, for they carried on some little cultivation of the soil, remained at a low level. Nature gave them, except in dry years, as much corn as they needed in return for very little labour. Clothing they did not need, and their isolation from the rest of the world left them ignorant of luxuries. When the European voyagers found them at the end of the fifteenth century, they were making little or no advance in the arts of life.

Upon the growth of European settlements the influence of the physical structure of the country has been very marked. When the Portuguese had followed the long line of coast from the mouth of the Orange River to that of the Zambesi, and from the mouth of the Zambesi northward to Zanzibar, they settled only where they heard that gold and ivory could be obtained. Their forts and trading stations, the first of which dates from I 505 , were 
therefore planted on the coast northward from the Limpopo River. Sofala, a little south of the modern port of Beira, was the principal one. Here they traded, and twice or thrice they made, always in search of the gold-producing regions, expeditions inland. These expeditions, however, had to traverse the flat and malarious strip of ground which lies along the Indian Ocean. A large part of the white troops died, and the rest arrived at the higher ground so much weakened that they could achieve no permanent conquests, for they were opposed by warlike tribes. In the course of years a small population speaking Portuguese, though mixed with native blood, grew up along the coast. The climate, however, destroyed what vigour the whites had brought from Europe, and by degrees they ceased to even attempt to conquer or occupy the interior. The heat and the rains, together with fever, the offspring of heat and rains, checked further progress. Three centuries passed, during which the knowledge of south-eastern Africa which the civilised world had obtained within the twenty years that followed the voyages of Vasco da Gama, was scarcely increased.

During those three centuries, America, which had not been discovered till six years after Bartholomew Diaz passed the Cape of Good Hope, had been, all except a part of the north-west, pretty thoroughly explored and partitioned out among five European powers. Large and prosperous colonies had sprung up and before the end of the eighteenth century 
one great independent state had established itself. The discovery of Australia and New Zealand came much later than that of America; but within one century from the first European settlement in Australia (A.D. I787) the whole continent, though its interior is uninviting, had been traversed along many lines, and five prosperous European colonies had grown to importance. The slow progress of exploration and settlement in South Africa during so long a period is therefore a noteworthy phenomenon which deserves a few observations.

As regards the Portuguese part of the East African coast, the explanation just given is sufficient. As regards that part of the West coast which lies south of the Portuguese colony of Angola, the natural features of the country make no explanation needed. No more arid or barren coast is to be found anywhere, and in its whole long stretch there is but one tolerable port, that of Walfish Bay. The inland region is scarcely better. Much of it is waterless and without herbage. No gold nor ivory nor other article of value was obtainable. Accordingly, nobody cared to settle or explore, and the land would probably be still lying unclaimed had not the settlement of Herr Luderitz and a vague desire for territorial expansion prompted Germany to occupy it in 1884 .

The south coast, from the Cape to the Tugela River, was much more attractive. Here the climate was salubrious, the land in many places fertile, and everywhere fit for sheep or cattle. Here, accordingly, 
a small European community, first founded in $165^{2}$, grew up and spread slowly eastward and northward along the shore during the century and a half from its first establishment. The Dutch settlers did not care to penetrate the interior, because the interior seemed to offer little to a farmer. Behind the well-watered coast belt lay successive lines of steep mountains, and behind those mountains the desert waste of the Karroo, where it takes six acres to keep a sheep. Accordingly, it was only a few bold hunters, a few farmers on the outskirts of the little maritime colony, and a few missionaries, who cared to enter this wide wilderness.

When exploration began, it began from this south-west corner of Africa. It began late. In I 806 , when the British took the Cape from the Dutch, few indeed were the white men who had penetrated more than one hundred miles from the coast, and the farther interior was known only by report. For thirty years more progress was slow; and it is within our own time that nearly all the exploration, and the settlement which has followed quickly on the heels of exploration, has taken place. Just sixty years ago the Dutch Boers passed in their heavy waggons from Cape Colony to the spots where Bloemfontein and Pretoria now stand. In I 854-56 David Livingstone made his way through Bechuanaland to the falls of the Zambesi and the west coast at $\mathrm{St}$. Paul de Loanda. In 1889 the vast territories between the Transvaal Republic and the Zambesi began to be occupied by the Mashonaland 
pioneers. All these explorers, all the farmers, missionaries, hunters, and mining prospectors, came up into South Central Africa from the south-west extremity of the continent over the great plateau. They moved north-eastward, because there was more rain, and therefore more grass and game in that direction than toward the north. They were checked from time to time by the warlike native tribes; but they were drawn on by finding everywhere a country in which Europeans could live and thrive. It was the existence of this high and cool plateau that permitted their discoveries and encouraged their settlement. And thus the rich interior has come to belong, not to the Portuguese, who first laid hold of South Africa, but to the races who first entered the plateau at the point where it is nearest the sea, the Dutch and the English. Coming a thousand miles by land, they have seized and colonised the country that lies within sixty or eighty miles of the ocean behind the Portuguese settlements, because they had good healthy air to breathe during all those thousand miles of journey; while the Portuguese, sunk among tropical swamps, were doing no more than maintains their hold upon the coast, and were allowing even the few forts they had established along the lower course of the Zambesi to crumble away.

The same natural conditions, however, which have made the plateau healthy, have kept it sparsely peopled. Much of this high interior, whose settlement has occupied the last sixty years, is a desert, 
CHAP.

unfit, and likely to be always unfit, for human habitation. Even in those parts which are comparatively well watered the grazing for sheep and cattle is so scanty during some months of the year that farms are large, houses are scattered far from one another, and the population remains extremely thin. The Wilderness of the Karroo cuts off Cape Town and its comparatively populous neighbourhood from the inhabited, though thinly inhabited, pastoral districts of the Orange Free State. Between these two settled districts there are only a few villages, scattered at intervals of many miles along a line of railway four hundred miles in length. In the Free State and the Transvaal the white population is extremely sparse, save in the mining region of the Witwatersrand, because ranching requires few hands, and only a few hundred square miles out of many thousands have been brought under cultivation. Thus, while the coolness of the climate has permitted Europeans to thrive in these comparatively low latitudes, its dryness has kept down their numbers and has retarded not only their political development, but their progress in all those arts and pursuits which imply a tolerably large and varied society. The note of South African life, the thing that strikes the traveller with increasing force as he visits one part of the country after another, is the paucity of inhabitants, and the isolated life which these inhabitants, except in six or seven towns, are forced to lead. This is the 
doing of nature. She has not severed the country into distinct social or political communities by any lines of physical demarcation, but she has provided such scanty means of sustenance for human life and so few openings for human industry unaided by capital, that the settlers (save where capital has come to their aid) remain few indeed, and one may call the interior of South Africa a vast solitude, with a few oases of population dotted here and there over it. 


\section{CHAPTER VII}

\section{ASPECTS OF SCENERY}

THE sketch I have given of the physical character of South Africa will doubtless have conveyed to the reader that the country offers comparatively little to attract the lover of natural scenery. This impression is true if the sort of landscape we have learned to enjoy in Europe and in the eastern parts of the United States be taken as the type of scenery which gives most pleasure. Variety of form, boldness of outline, the presence of water in lakes and running streams, and, above all, foliage and verdure, are the main elements of beauty in those landscapes; while if any one desires something of more imposing grandeur, he finds it in snow-capped mountains like the Alps or the Cascade Range, or in majestic crags such as those which tower over the fiords of Norway. But the scenery of South Africa is wholly unlike that of Europe or of most parts of America. It is, above all things, a dry land, a parched and thirsty land, where no clear brooks murmur through the meadow, no cascade sparkles from the cliff, where mountain and plain alike are 
brown and dusty except during the short season of the rains. And being a dry land, it is also a bare land. Few are the favoured spots in which a veritable forest can be seen; for though many tracts are wooded, the trees are almost always thin and stunted. In Matabililand, for instance, though a great part of the surface is covered with wood, you see no trees forty feet high, and few reaching thirty; while in the wilderness of the Kalahari Desert and Damaraland nothing larger than a bush is visible, except the scraggy and thorny mimosa.

These features of South Africa-the want of water and the want of greenness-are those to which a native of Western Europe finds it hardest to accustom himself, however thoroughly he may enjoy the brilliant sun and the keen dry air which go along with them. And it must also be admitted that over very large areas the aspects of nature are so uniform as to become monotonous. One may travel eight hundred miles and see less variety in the landscape than one would find in one fourth of the same distance anywhere in Western Europe or in America east of the Alleghany Mountains. The same geological formations prevail over wide areas, and give the same profile to the hilltop, the same undulations to the plain; while in travelling northward toward the Equator the flora seems to change far less between $34^{\circ}$ and $18^{\circ}$ south latitude than it changes in the journey from Barcelona to Havre, through only half as many degrees of latitude. 
CHAP.

There are, nevertheless, several interesting bits of scenery in South Africa, which, if they do not of themselves repay the traveller for so long a journey, add sensibly to his enjoyment. The situation of Cape Town, with a magnificent range of precipices rising behind it, a noble bay in front, and environs full of beautiful avenues and pleasuregrounds, while bold mountain-peaks close the more distant landscape, is equalled by that of few other cities in the world. Constantinople and Naples, Bombay and San Francisco, cannot boast of more perfect or more varied prospects. There are some fine pieces of wood and water scenery along the south coast of Cape Colony, and one of singular charm in the adjoining colony of Natal, where the suburbs of Durban, the principal port, though they lack the grandeur which its craggy heights give to the neighbourhood of Cape Town, have, with a warmer climate, a richer and more tropically luxuriant vegetation. In the great range of mountains which runs some seventeen hundred miles from Cape Town almost to the banks of the Zambesi, the scenery becomes striking in three districts only. One of these is Basutoland, a little native territory which lies just where Cape Colony, the Orange Free State, and Natal meet. Its peaks are the highest in Africa south of Mount Kilimanjaro, for several of them reach I I,000 feet. On the south-east this mountain-land, the Switzerland of South Africa, faces Natal and East Griqualand with a long range of formidable precipices, 
impassable for many miles. The interior contains valleys and glens of singular beauty, some wild and rugged, some clothed with rich pasture. The voice of brooks, a sound rare in Africa, rises from the hidden depths of the gorges, and here and there torrents plunging over the edge of a basaltic cliff into an abyss below make waterfalls which are at all seasons beautiful, and when swollen by the rains of January majestic. Except wood, of which there is unhappily nothing more than a little scrubby bush in the sheltered hollows, nearly all the elements of beauty are present; and the contrast between the craggy summits and the soft rich pasture and cornlands which lie along their northern base, gives rise to many admirable landscapes.

Two hundred miles north-north-east of Basutoland the great Quathlamba Range rises in very bold slopes from the coast levels behind Delagoa Bay, and the scenery of the valleys and passes is said to be extremely grand. Knowing it, however, only by report, I will not venture to describe it. Nearly five hundred miles still farther to the north, in the district called Manicaland, already referred to, is a third mountain region, less lofty than Basutoland, but deriving a singular charm from the dignity and variety of its mountain forms. The whole country is so elevated that summits of 7000 or even 8000 feet do not produce any greater effect upon the eye than does Ben Lomond as seen from Loch Lomond, or Mount Washington from the Glen House. But there is a boldness of line about these 
granite peaks comparable to those of the west coast of Norway or of the finest parts of the Swiss Alps. Some of them rise in smooth shafts of apparently inaccessible rock; others form long ridges of pinnacles of every kind of shape, specially striking when they stand out against the brilliantly clear morning or evening sky. The valleys are well wooded, the lower slopes covered with herbage, so the effect of these wild peaks is heightened by the softness of the surroundings which they dominate, while at the same time the whole landscape becomes more complex and more noble by the mingling of such diverse elements. No scenery better deserves the name of romantic. And even in the tamer parts, where instead of mountains there are only low hills, or "kopjes" (as they are called in South Africa), the slightly more friable rock found in these hills decomposes under the influence of the weather into curiously picturesque and fantastic forms, with crags riven to their base, and detached pillars supporting loose blocks and tabular masses, among or upon which the timid Mashonas have built their huts in the hope of escaping the raids of their warlike enemies, the Matabili.

Though I must admit that South Africa, taken as a whole, offers far less to attract the lover of natural beauty than does Southern or Western Europe or the Pacific States of North America, there are two kinds of charm which it possesses in a high degree. One is that of colour. Monotonous as the landscapes often are, there is a warmth and richness of tone 
about them which fills and delights the eye. One sees comparatively little of that whitish-blue limestone which so often gives a hard and chilling aspect to the scenery of the lower ridges of the Alps and of large parts of the coasts of the Mediterranean. In Africa even the grey granite or gneiss has a deeper tone than these limestones, and it is frequently covered by red and yellow lichens of wonderful beauty. The dark basalts and porphyries which occur in many places, the rich red tint which the surface of the sandstone rocks often takes under the scorching sun, give depth of tone to the landscape; and though the flood of midday sunshine is almost overpowering, the lights of morning and evening, touching the mountains with every shade of rose and crimson and violet, are indescribably beautiful. It is in these morning and evening hours that the charm of the pure dry air is specially felt. Mountains fifty or sixty miles away stand out clearly enough to enable all the wealth of their colour and all the delicacy of their outlines to be perceived; and the eye realises, by the exquisitely fine change of tint between the nearer and the more distant ranges, the immensity and the harmony of the landscape. Europeans may think that the continuous profusion of sunlight during most of the year may become wearisome. I was not long enough in the country to find it so, and I observed that those who have lived for a few years in South Africa declare they prefer that continuous profusion to the murky skies of Britain or Holland or North Germany. But even 
if the fine weather which prevails for eight months in the year be monotonous, there is compensation in the extraordinary brilliancy of the atmospheric effects throughout the rainy season, and especially in its first weeks. During nine days which I spent in the Transvaal at that season, when several thunderstorms occurred almost every day, the combinations of sunshine, lightning, and cloud, and the symphonies-if the expression may be permittedof light and shade and colour which their changeful play produced in the sky and on the earth, were more various and more wonderful than a whole year would furnish forth for enjoyment in most parts of Europe.

The other peculiar charm which South African scenery possesses is that of primeval solitude and silence. It is a charm which is differently felt by different minds. There are many who find the presence of what Homer calls "the rich works of men " essential to the perfection of a landscape. Cultivated fields, gardens, and orchards, farmhouses dotted here and there, indications in one form or another of human life and labour, do not merely give a greater variety to every prospect, but also impart an element which evokes the sense of sympathy with our fellow-beings, and excites a whole group of emotions which the contemplation of nature, taken by itself, does not arouse. No one is insensible to these things, and some find little delight in any scene from which they are absent. Yet there are other minds to which there is something specially solemn and impressive in the un- 
touched and primitive simplicity of a country which stands now just as it came from the hands of the Creator. The self-sufficingness of nature, the insignificance of man, the mystery of a universe which does not exist, as our ancestors fondly thought, for the sake of man, but for other purposes hidden from us and for ever undiscoverable-these things are more fully realised and more deeply felt when one traverses a boundless wilderness which seems to have known no change since the remote ages when hill and plain and valley were moulded into the forms we see to-day. Feelings of this kind powerfully affect the mind of the traveller in South Africa. They affect him in the Karroo, where the slender line of rails, along which his train creeps all day and all night across wide stretches of brown desert and under the crests of stern dark hills, seems to heighten by contrast the sense of solitude-a vast and barren solitude interposed between the busy haunts of men which he has left behind on the shores of the ocean and those still busier haunts whither he is bent, where the pick and hammer sound upon the Witwatersrand, and the palpitating engine drags masses of ore from the depths of the crowded mine. They affect him still more in the breezy highlands of Matabililand, where the eye ranges over an apparently endless succession of undulations clothed with tall grass or waving wood, till they sink in the blue distance toward the plain through which the great Zambesi takes its seaward course. 
The wilderness is indeed not wholly unpeopled. Over the wide surface of Matabililand and Mashonaland-an area of some two hundred thousand square miles-there are scattered natives of various tribes, whose numbers have been roughly estimated at from 250,000 to 400,000 persons. But one rarely sees a native except along a few well-beaten tracks, and still more rarely comes upon a cluster of huts in the woods along the streamlets or half hidden among the fissured rocks of a granite kopje. The chief traces of man's presence in the landscape are the narrow and winding footpaths which run hither and thither through the country, and bewilder the traveller who, having strayed from his waggon, vainly hopes by following them to find his way back to the main track, or the wreaths of blue smoke which indicate the spot where a Kafir has set the grass on fire to startle and kill the tiny creatures that dwell in it.

Nothing is at first more surprising to one who crosses a country inhabited by savages than the few marks of their presence which strike the eye, or at least an unpractised eye. The little plot of ground the Kafirs have cultivated is in a few years scarcely distinguishable from the untouched surface of the surrounding land, while the mud-built hut quickly disappears under the summer rains and the scarcely less destructive efforts of the white ants. Here in South Africa the native races seem to have made no progress for centuries, if, indeed, they have not actually gone backward; and the feebleness of 
savage man intensifies one's sense of the overmastering strength of nature. The elephant and the buffalo are as much the masters of the soil as is the Kafir, and man has no more right to claim that the land was made for him than have the wild beasts of the forest who roar after their prey and seek their meat from God.

These features of South African nature, its silence, its loneliness, its drear solemnity, have not been without their influence upon the mind and temper of the European settler. The most peculiar and characteristic type that the country has produced is the Boer of the eastern plateau, the offspring of those Dutch Africanders who some sixty years ago wandered away from British rule into the wilderness. These men had, and their sons and grandsons have retained, a passion for solitude that even to-day makes them desire to live many miles from any neighbour, a sturdy self-reliance, a grim courage in the face of danger, a sternness from which the native races have often had to suffer. The majesty of nature has not stimulated in them any poetical faculty. But her austerity, joined to the experiences of their race, has contributed to make them grave and serious, closely bound to their ancient forms of piety, and prone to deem themselves the special objects of divine protection. 



\section{PART II}

A SKETCH OF SOUTH AFRICAN HISTORY 



\section{CHAPTER VIII}

THE NATIVES: HOTTENTOTS, BUSHMEN, AND KAFIRS

By far the most interesting features in the history of South Africa have been the relations to one another of the various races that inhabit it. There are seven of these races, three native and four European. The European races, two of them especially, the Dutch and the English, are, of course, far stronger, and far more important as political factors, than are the natives. Nevertheless, the natives have an importance too, and one so great that their position deserves to be fully set forth and carefully weighed. For, though they are inferior in every point but one, they are in that point strong. They are prolific. They already greatly outnumber the whites, and they increase - faster.

$=$ The cases of conflict or contact between civilized European man and savage or semi-civilized aboriginal peoples, which have been very numerous since the tide of discovery began to rise in the end of the fifteenth century, may be reduced to three classes. 
The first of these classes includes the cases where the native race, though perhaps numerous, is comparatively weak, and unable to assimilate European civilization, or to thrive under European rule (a rule which has often been harsh), or even to survive in the presence of a European population occupying its country. To this class belong such cases as the extinction of the natives of the Antilles by the Spaniards, the disappearance of the natives of Southern Australia and Tasmania before British settlement, the dying out, or retirement to a few reserved tracts, of the aborigines who once occupied all North America east of the Rocky Mountains. The Russian advance in Siberia, the advance of Spanish and Italian and German colonists in the territories of La Plata in South America, may be added to this class, for, though the phenomena are rather those of absorption than of extinction, the result is practically the same. The country becomes European and the native races vanish.

= An opposite class of cases arises where Europeans have conquered a country already filled by a more or less civilized population, which is so numerous and so prolific as to maintain itself with ease in their presence. Such a case is the British conquest of India. The Europeans in India are, and must remain, a mere handful among the many millions of industrious natives, who already constitute, in many districts, a population almost too numerous for the resources of the country to sup- 
port. Moreover, the climate is one in which a pure European race speedily dwindles away. The position of the Dutch in Java, and of the French in Indo-China, is similar; and the French in Madagascar will doubtless present another instance.

Between these two extremes lies a third group of cases-those in which the native race is, on the one hand, numerous and strong enough to maintain itself in the face of Europeans, while, on the other hand, there is plenty of room left for a considerable European population to press in, climatic conditions not forbidding it to spread and multiply. To this group belong such colonizations as those of the Spaniards in Mexico and Peru, of the Russians in parts of Central Asia, of the French in Algeria and Tunis, of the Spaniards in the Canary Isles, and of the English and Americans in Hawaii. In all these countries the new race and the old race can both live and thrive, neither of them killing off or crowding out the other, though in some, as in Hawaii, the natives tend to disappear, while in others, as in Algeria, the immigrants do not much increase. Sometimes, as in the Canary Isles and Mexico, the two elements blend, the native element being usually more numerous, though less advanced; and a mixed race is formed by intermarriage. Sometimes they remain, and seem likely to remain, as distinct as oil is from water.

South Africa belongs to this third class of cases. The Dutch and the English find the country a good one and become fond of it. There is plenty 
of land for them. They enjoy the climate. They thrive and multiply. But they do not oust the natives, except sometimes from the best lands, and the contact does not reduce the number of the latter. The native-that is to say, the native of the Kafir race-not merely holds his ground, but increases far more rapidly than he did before Europeans came, because the Europeans have checked intertribal wars and the slaughter of the tribesmen by the chiefs and their wizards, and also because the Europeans have opened up new kinds of employment. As, therefore, the native will certainly remain, and will, indeed, probably continue to be in a vast majority, it is vital to a comprehension of South African problems to know what he has been and may be expected to become.

The native races are three, and the differences between them are marked, being differences not only of physical appearance and of language, but also of character, habits, and grade of civilization. These three are the Bushmen, the Hottentots, and those Bantu tribes whom we call Kafirs.

The Bushmen were, to all appearance, the first on the ground, the real aborigines of South Africa. They are one of the lowest races to be found anywhere, as low as the Fuegians or the "black fellows" of Australia, though perhaps not quite so low as the Veddahs of Ceylon or the now extinct natives of Tasmania. They seem to have been originally scattered over all South Africa, from the Zambesi 
to the Cape, and so late as eighty years ago were almost the only inhabitants of Basutoland, where now none of them are left. They were nomads of the most primitive type, neither tilling the soil nor owning cattle, but living on such wild creatures as they could catch or smite with their poisoned arrows, and, when these failed, upon wild fruits and the roots of plants. For the tracking and trapping of game they had a marvellous faculty, such as neither the other races nor any European could equal. But they had no organization, not even a tribal one, for they wandered about in small groups; and no religion beyond some vague notion of ghosts, and of spirits inhabiting or connected with natural objects; while their language was a succession of clicks interrupted by grunts. Very low in stature, and possibly cognate to the pygmies whom $\mathrm{Mr}$. H. M. Stanley found in Central Africa, they were capable of enduring great fatigue and of travelling very swiftly. Untamably fierce unless caught in childhood, and incapable of accustoming themselves to civilized life, driven out of some districts by the European settlers, who were often forced to shoot them down in self-defence, and in other regions no longer able to find support owing to the disappearance of the game, they are now almost extinct, though a few remain in the Kalahari Desert and the adjoining parts of northern Bechuanaland and western Matabililand, toward Lake Ngami. I saw at the Kimberley mines two or three dwarf natives who were said to have Bushmen blood in them, but. 
it is no longer easy to find in the Colony a pure specimen. Before many years the only trace of their existence will be in the remarkable drawings of wild animals with which they delighted to cover the smooth surfaces of sheltered rocks. These drawings, which are found all the way from the Zambesi to the Cape, and from Manicaland westward, are executed in red, yellow, and black pigments, and are often full of spirit. Rude, of course. they are. but they often conver the aspect, and especially the characteristic attitude, of the animal with great fidelity.

$=$ The second native race was that which the Dutch called Hottentor, and whom the Portuguese explorers found occupying the maritime region in the south-west corner of the continent, to the east and to the north of the Cape of Good Hope. They are supposed to have come from the north and dispossessed the Bushmen of the grassy coast lands. driving them into the more arid interior. But of this there is no evidence; and some have even fancied that the Hottentot race itself may have been a mixed one produced by intermarriage between Bushmen and Kafirs. Be this as it may. the Hottentots were superior to the Bushmen both physicaily and intellectually. They were small men. but not prgmies. of a reddish or yellowish black hue, with no great muscular power in their slender frames. Their hair, very short and woolly, grew, like that of the Bushmen, in small balls or tufts over the skull, just as grass-tufts grow separate from one 
another in the drier parts of the veldt. They possessed sheep and also cattle, lean beasts with huge horns; and they roved hither and thither over the country as they could find pasture for their animals, doing a little hunting, but not attempting to till the soil, and unacquainted with the metals. Living in tribes under their chiefs, they fought a little with one another, and a great deal with the Bushmen, who tried to prey upon their cattle. They were a thoughtless, cheerful, good-natured, merry sort of people, whom it was not difficult to domesticate as servants, and their relations with the Dutch settlers, in spite of two wars, were, on the whole, friendly. Within a century after the foundation of Cape Colony, their numbers, never large, had vastly diminished, partly from the occupation by the colonists of their best grazing-grounds, but still more from the ravages of small-pox and other epidemics, which ships touching on their way from the East Indies brought into the country. In A.D. I7I3 whole tribes perished in this way. I speak of the Hottentots in the past tense, for they are now, as a distinct race, almost extinct in the Colony, although a good deal of their blood has passed into the mixed coloured population of Cape Town and its neighbourhood-a population the other elements of which are Malays from the Dutch East Indies, and the descendants of slaves brought from the West Coast of Africa in the seventeenth and eighteenth centuries. From unions between Hottentot women and the Dutch sprang 
CHAP.

the mixed race whom the Dutch call Bastards and the English Griquas, and who, though now dying out like the French-and-Indian half-breeds of western Canada, played at one time a considerable part in colonial politics. Along the south bank of the Orange River and to the north of it, in Great Namaqualand, small tribes, substantially identical with the Hottentots, still wander over the arid wilderness. But in the settled parts of the Colony the Hottentot, of whom we used to hear so much, and whom the Portuguese, remembering the death of the viceroy D'Almeida (who was killed in a skirmish in A.D. I 5 IO), at one time feared so much, has vanished more completely than has the Red Indian from the Atlantic States of North America. And the extinction or absorption of the few remaining nomads will probably follow at no distant date.

Very different have been the fortunes, very different are the prospects, of the third and far more numerous South African race, those whom we call Kafirs, and who call themselves Abantu or Bantu (" the people"). The word "Kafir" is Arabic. It has nothing to do with Mount Kaf (the Caucasus), but means an infidel (literally, "one who denies"), and is applied by Mussulmans not merely to these people, but to other heathen also, as, for instance, to the idolaters of Kafiristan, in the Hindu-Kush Mountains. The Portuguese doubtless took the name from the Arabs, whom they found established at several points on the East African coast northward from Sofala, and the Dutch took it from the 
Portuguese, together with such words as "kraal" (corral) and "assagai." The Bantu tribes, if one may include under that name all the blacks who speak languages of the same general type, occupy the whole of East Africa southward from the Upper Nile, where that river issues from the great Nyanza lakes, together with the Congo basin and most of South-west Africa. They include various groups, such as the Ama-Kosa tribes (to which belong the Tembus and Pondos), who dwell on the coast of Cape Colony eastward from the Great Fish River ; the Ama-Zulu group, consisting of the Zulus proper (in Natal and Zululand), the Swazis, the Matabili, farther to the north, and the Angoni, in Nyassaland, beyond the Zambesi River; the Amatonga group, between Zululand and Delagoa Bay; the Bechuana group, including the Bamangwato, the Basuto and the Barolongs, as well as the Barotse, far off on the middle course of the Zambesi; the Makalaka or Maholi, and cognate tribes, inhabiting Mashonaland and Manicaland. The linguistic and ethnical affinities of these groups and tribes are still very imperfectly known, but their speech and their habits are sufficiently similar to enable us to refer them to one type, just as we do the Finnic or the Slavonic peoples in Europe. And they are even more markedly unlike the Hottentots or the Bushmen than the Slavs are to the Finns, or both of these to those interesting aborigines of northern Europe, the Lapps.

The Bantu or Kafirs-I use the term as syno- 
nymous-who dwell south of the Zambesi are usually strong and well-made men, not below the average height of a European. In colour they vary a good deal ; some are as black as a Gulf of Guinea negro, some rather brown than black. All have the thick lips, the woolly hair, and the scanty beard of the negro, and nearly all the broad, low nose; yet in some the nose is fairly high, and the cast of features suggests an admixture of Semitic bloodan admixture which could be easily explained by the presence, from a pretty remote time, of Arab settlers, as well as traders, along the coast of the Indian Ocean. As the Bantu vary in aspect, so do they also in intelligence. No tribe is in this respect conspicuously superior to any other, though the Zulus show more courage in fight than most of the others, the Fingos more aptitude for trade, the Basutos more disposition to steady industry. But, while the general level of intellect is below that of the Red Indians or the Maoris or the Hawaiians (if rather above that of the Guinea negroes), individuals are now and then found of considerable talents and great force of character. Three such men as the Zulu Tshaka, the Basuto Moshesh, and the Bechuana Khama, not to speak of those who, like the eloquent missionary Tiyo Soga, have received a regular European education, are sufficient to show the capacity of the race for occasionally reaching a standard which white men must respect. And in one regard the Bantu race shows a kind of strength which the Red Indians and Polynesians lack. They 
are a very prolific people, and under the conditions of peace which European rule secures they multiply with a rapidity which some deem alarming.

How long the various Bantu tribes have been in South Africa is a question on which no light has yet been thrown, or can, indeed, be expected. Some of them have a vague tradition that they came from the north; but the recollections of savages seldom go back more than five or six generations, and retain little except the exploits or the genealogy of some conspicuous chief. When the Portuguese arrived in the end of the fifteenth century, they found Kafirs already inhabiting the country from Natal northward. But apparently they did not then extend as far to the west of Natal as they do now, and there is reason to think that considerable parts of the interior, such as the region which is now the Orange Free State and Basutoland, were not yet occupied, but left to the wandering Bushmen. The Kafirs were then, and continued down to our own time, in a state of incessant tribal warfare; and from time to time one martial tribe, under a forceful chief, would exterminate or chase a way some weaker clan and reduce wide areas to a wilderness. Of any large conquests, or of any steady progress in the arts either of war or of peace, there is no record, and, indeed, in the general darkness, no trace. The history of the native races, so far as ascertainable, begins with the advent of the whites, and even after their advent remains extremely shadowy until, early in this century, the onward march of settlement 
gave the Dutch and English settlers the means of becoming better acquainted with their black neighbours.

Across this darkness there strikes one ray of light. It is a very faint ray, but in the absence of all other light it is precious. It is that which is supplied by the prehistoric ruins and the abandoned goldworkings of Mashonaland. 


\section{CHAPTER IX}

OUT OF THE DARKNESS-ZIMBABWYE

THE ruined buildings of Mashonaland and Matabililand have excited in recent years an amount of interest and curiosity which is disproportionate to their number, size, and beauty, but by no means disproportionate to their value as being the only record, scant as it is, we possess of what has been deemed an early South African civilization. I will describe in the fewest words such of these buildings as I saw, leaving the reader of archæological tastes to find fuller details in the well-known book of that enterprising explorer, Mr. Theodore Bent. ${ }^{1}$ Some short account of them seems all the more needed, because the first descriptions published gave the impression that they were far more considerable than they really are.

Scattered over the plateau of southern Mashonaland and Matabililand, from its mountainous edge on the east to the neighbourhood of Tati on the west, there are to be found fragments of walls built of

1 Unhappily lost to science by premature death since the above lines were written. 
small blocks of granite resembling paving stones (usually about a foot long by six inches high), but often larger, not cut smooth, but chipped or trimmed to a fairly uniform size. These walls are without mortar or other cementing material, but the stones are so neatly set together, and the wall usually so thick, that the structure is compact and cohesive. The walls are mostly thinner at the top than at the base. The only ornamentation consists in placing some of the layers at an acute angle to the other layers above and below, so as to produce what is called the herring-bone pattern. Occasionally a different pattern is obtained by leaving spaces at intervals between the horizontal stones of certain layers, making a kind of diaper. In some cases this ornamentation, always very simple, occurs only on one part of the wall, and it has been said that it occurs usually if not invariably on the part which faces the east. I heard of ten or twelve such pieces of wall in different parts of the plateau, and saw photographs of most of these. Probably others exist, for many districts, especially in the hills, have been imperfectly explored, and trees easily conceal these low erections. One was described to me, where the walls are the facings of seven terraces, rising one above another to a sort of platform on the top. This I have not seen; but it is probably similar to one which I did see and examine at a place called Dhlodhlo, about fifty miles south-east of Bulawayo. This group of ruins, one of the most interesting in the country, stands high 
among rocky hills, from which a superb view is gained over the wide stretches of rolling table-land to the north and north-west, a charming situation which might have attracted the old builders did they possess any sense of beauty. On a low eminence there has been erected such a wall of such hewn, or rather trimmed, stones as I have just described. It is now about twenty feet in height, and may have originally been higher. On the eastern side this wall consists of three parts, each about six feet high, with two narrow terraces, each from five to six feet wide, between them, the second wall rising from the first terrace, and the third or highest wall from the second terrace. On this side some of the stone courses have the simple forms of ornamental pattern already mentioned. On the opposite, or western and north-western, side only one terrace and a low, unornamented wall of trimmed stones are now discernible. To the north, still within what seems to have been the main inclosing wall, are small inclosures built of trimmed stone, which may have been chambers originally roofed with wood or bushes. At the top of the highest wall there is at the northnorth-west end a small level platform of earth or rubble, which seems to have been filled in behind the terraced walls. This platform is approached by a narrow passage between walls of trimmed stone, at one point in which there appears to have been a sort of narrow gateway barely wide enough for two persons to pass. There is no trace of any stone building on the top of the platform, and the remains 
of clay huts which one finds there may well be quite modern. To the south of this principal structure there is a second small hill or boss of granite, protected on three sides by steep sheets of granite rock. Its top is enclosed by a low wall of trimmed stones, now in places quite broken away, with no trace of any stone building within. All round on the lower ground are large inclosures rudely built of rough stones, and probably intended for cattle-kraals. They may be quite modern, and they throw no light on the purpose of the ancient buildings. Nor is much light to be obtained from the objects which have been found in the ruins. When I was there they were being searched by the Mashonaland Ancient Ruins Exploration Company, a company authorized by the British South Africa Company to dig and scrape in the ancient buildings of the country for gold or whatever else of value may be there discoverable, an enterprise which, though it may accelerate the progress of archæological inquiry, obviously requires to be conducted with great care and by competent persons. So far as I could observe, all due care was being used by the gentleman in charge of the work at Dhlodhlo; but considering how easy it is to obliterate the distinctive features of a ruin and leave it in a condition unfavourable to future examination, it seems desirable that the company should, as a rule, await the arrival of trained archæologists rather than hurry on explorations by amateurs, however zealous and well intentioned. Of the objects found, which 
were courteously shown to me, some are modern, such as the bits of pottery, apparently Indian or Chinese, the bits of glass, the bullets and fragments of flint-lock muskets, a small cannon, and an iron hammer. These are doubtless of Portuguese origin, though it does not follow that any Portuguese expedition ever penetrated so far inland, for they may have been gifts or purchases from the Portuguese established on the coast four or five hundred miles away. So, too, the silver and copper ornaments found, and some of the gold ones (occasionally alloyed with copper), which show patterns apparently Portuguese, may be recent. There are also, however, some gold ornaments, such as beads, bangles (a skeleton was found with bangles on the legs and a bead necklace), and pieces of twisted gold wire, which may be far more ancient, and indeed as old as the structure itself. A small crucible with nuggets and small bits of gold goes to indicate that smelting was carried on, though the nearest ancient goldworkings are six miles distant. Probably here, as at Hissarlik and at Carthage, there exist remains from a long succession of centuries, the spot having been occupied from remote antiquity. ${ }^{1}$ At present it is not only uninhabited, but regarded by the natives with fear. They believe it to be haunted by

1 Mr. Neal, managing director of the Company, has been good enough to inform me that since my visit he satisfied himself that there had been occupations by different races and probably at widely distant dates. Many skeletons have been found, with a good deal of gold jewelry, and some bronze implements. 
CHAP.

the ghosts of the departed, and are unwilling, except in the daytime and for wages paid by the Exploration Company, to touch or even to enter the ruins. They can hardly be persuaded even to relate such traditions as exist regarding the place. All that has been gathered is that it was the dwelling of a line of mambos, or chiefs, the last of whom was burned here by Mosilikatze, the Matabili king, when he conquered the country sixty years ago. (The place does show marks of fire.) But the buildings were here long before the mambos reigned, and who built them, or why, no one knows. The natives come sometimes to make offerings to ancestral ghosts, especially when they ask for success in hunting; and if the hunt be successful, strips of meat are cut off and placed in cleft sticks for the benefit of the ghosts.

Three hypotheses have been advanced regarding the Dhlodhlo buildings. One regards them as a fortress. The objection to this is that the terraced and ornamented wall is so far from contributing to defence that it actually facilitates attack ; for, by the help of the terraces and of the interstices among the stones which the ornamental pattern supplies, an active man could easily scale it in front. Moreover, there is hard by, to the north, a higher and more abrupt hill which would have offered a far better site for a fort. The second view is that Dhlodhlo was a mining station, where slaves were kept at work ; but if so, why was it not placed near the old gold-workings instead of some miles off, and of what use were the terraced walls? The inquirer is 
therefore led to the third view-that the building was in some way connected with religious worship, and that the ornament which is seen along the eastern wall was placed there with some religious motive. There is, however, nothing whatever to indicate the nature of that worship, nor the race that practised it, for no objects of a possibly religious character (such as those I shall presently mention at Zimbabwye) have been found here.

I visited a second ruin among the mountains of Mashonaland, near the Lezapi River, at a place called Chipadzi's grave, a mile from the kraal of a chief named Chipunza. Here a rocky granite kopje, almost inaccessible on two sides, is protected on one of the other sides by a neatly built wall of well-trimmed stones, similar to that at Dhlodhlo, but without ornament. The piece that remains is some fifty yards long, five feet thick at the base, and eleven feet high at its highest point. It is obviously a wall of defence, for the only erections within are low, rough inclosures of loose stones, and three clay huts, one of which covers the grave of Chipadzi, a chief who died some twenty years ago, and who was doubtless interred here because the place was secluded and already in a fashion consecrated by the presence of the ancient wall. That the wall is ancient hardly admits of doubt, for it is quite unlike any of the walls-there are not many in the country - which the Kafirs now build, these being always of stones entirely untrimmed and very loosely fitted together, though sometimes plastered with mud to 
CHAP.

make them hold. ${ }^{1}$ There is nothing to see beyond the wall itself, and the only interest of the place is in its showing that the race who built Dhlodhlo and other similar walls in Matabililand were probably here also.

Much larger and more remarkable is the group of ruins (situated seventeen miles from Fort Victoria, in southern Mashonaland) which goes by the name of the Great Zimbabwye. This Bantu word is said to denote a stone building, but has often been used to describe the residence of a great chief, whatever the materials of which it is constructed. It is a common noun, and not the name of one particular place. Europeans, however, confine it to this one ruin, or rather to two ruined buildings near each other. One of these is on the top of a rocky and in parts precipitous hill, the other in a valley half a mile from the foot of the hill.

The first, which we may call the Fort, consists of a line of wall, in parts double, defending the more accessible parts of the eastern and south-eastern end of the hill or kopje, which is about 500 feet high, and breaks down on its southern side in a nearly vertical sheet of granite. The walls, which in some

1 This place is described by Mr. Selous in his interesting book, A Hunter's Wanderings in Africa, pp. 339-34t. He thinks the wall as well built as those at the Great Zimbabwye. To me it seemed not so good, and a little rougher even than the work at Dhlodhlo. Hard by is a modern Kafir fort, Chitikete, with a plastered and loop-holed rough stone wall, quite unlike this wall at Chipadzi's grave. This place is further described in Chapter XVI. 
places are thirty feet high, are all built of small trimmed blocks of granite such as I have already described, without mortar, but neatly fitted together. They are in excellent preservation, and are skilfully constructed, in a sort of labyrinth, so as to cover all the places where an enemy might approach. From the openings in the wall, where doors were probably placed, passages are carried inward, very narrow and winding, so that only one person at a time can pass, and completely commanded by the high wall on either side. Everything speaks of defence, and everything is very well adapted, considering the rudeness of the materials, for efficient defence. There is no sort of ornament in the walls, except that here and there at the entrances some stones are laid transversely to the others, and that certain long, thin pieces of a slaty stone, rounded so that one might call them stone poles-they are about five to seven feet long-project from the top of the wall. Neither is there any trace of an arch or vaulted roof. None of what look like chambers has a roof. They were doubtless covered with the branches of trees. Very few objects have been found throwing any light on the object of the building or its builders, and these have been now removed, except some small pieces of sandstone, a rock not found in the neighbourhood, which (it has been conjectured) may have been brought for the purposes of mining.

The other building is much more remarkable. It stands on a slight eminence in the level ground be- 
tween the hill on which the Fort stands and another somewhat lower granite hill, and is about a third of a mile from the Fort. It consists of a wall, rather elliptical than circular in form, from thirty to forty feet high, fourteen feet thick near the ground, and from six to nine thick at the top, where one can walk along a considerable part with little difficulty. This wall is built of the same small, well-trimmed blocks of granite, nicely fitted together, and for more than half the circumference is in excellent preservation, although shrubs and climbing vines have here and there rooted themselves in it. The rest of it is more or less broken, and in one place quite overthrown. There are two gates, at the west and the north. The wall is quite plain, except for about one third (or perhaps a little less) of the outer face, where there is such an ornament as I have already described, of two courses of stones set slantingly at an acute angle to the ordinary flat courses above and below. These two courses are the fifth and seventh from the top. In the space surrounded by the wall, which is about three quarters of an acre, are some small inclosures of trimmed stone, apparently chambers. There is also a singular wall running parallel to the inner face of the great inclosing wall for some twenty yards, leaving between it and that inner face a very narrow passage, which at one point must have been closed by a door (probably of stone), for at that point steps lead up on either side, and hollow spaces fit for receiving a door remain. At one end this passage opens into a small 
open space, where the most curious of all the erections are to be found, namely, two solid towers of trimmed stones. One of these is quite low, rising only some five feet from the ground. The other is more than forty feet high, overtopping the great inclosing wall (from which it is eight feet distant) by about five feet, and has a bluntly conical top. It reminds one a little of an Irish round tower, though not so high, save that the Irish towers are hollow and this solid, or of a Buddhist tope, save that the topes, which are solid, are very much thicker. There is nothing whatever to indicate the purpose of this tower, but the fact that the space in which it and the smaller tower stand is cut off from the rest of the inclosed area by a pretty high wall seems to show that it was meant to be specially protected or was deemed to be specially sacred.

Outside the main inclosing wall are several small inclosures of irregular shape, surrounded by similar walls of trimmed stones, but all low and broken and with nothing inside. One of these joins on to the main wall of the great inclosure.

This is all that there is to see at Zimbabwye. What I have described seems little, and that little is simple, even rude. The interest lies in guessing what the walls were built for, and by whom. Comparatively little has been discovered by digging. No inscriptions whatever have been found. Some figures of birds rudely carved in a sort of soapstone were fixed along the top of the walls of the Fort, and have been removed to the Cape Town museum. It 
is thought that they represent vultures, and the vulture was a bird of religious significance among some of the Semitic nations. Fragments of soapstone bowls were discovered, some with figures of animals carved on them, some with geometrical patterns, while on one were marks which might possibly belong to some primitive alphabet. There were also whorls somewhat resembling those which occur so profusely in the ruins of Troy, and stone objects which may be phalli, though some at least of them are deemed by the authorities of the British Museum (to whom I have shown them) to be probably pieces used for playing a game like that of foxand-geese. The iron and bronze weapons which were found may have been comparatively modern, but the small crucibles for smelting gold, with tools and a curious ingot-mold (said to resemble ancient moulds used at tin workings) were apparently ancient.

What purpose were these buildings meant to serve? That on the hill was evidently a stronghold, and a stronghold of a somewhat elaborate kind, erected against an enemy deemed formidable. The large building below can hardly have been a place of defence, because it stands on level ground with a high, rocky hill just above it, which would have afforded a much stronger situation. Neither was it a mining station, for the nearest place where any trace of gold has been found is seven miles away, and in a mining station, even if meant to hold slave workers, there would have been no use for a 
wall so lofty as this. Two hypotheses remain: that this was the residence of a chief, or that it was erected for the purposes of religious worship. It may have been both - a palace, so to speak, with a temple attached. The presence of the inner inclosure, guarded by its separate wall, and with its curious tower, is most plausibly explained by supposing a religious purpose, for as religion is the strangest of all human things, and that in which men most vary, so it is naturally called in to explain what is otherwise inexplicable.

What, then, was the religion of those who built this shrine, if shrine it was? The ornamentation of that part of the outer wall which faces the rising sun suggests sun-worship. The phalli (if they are phalli) point to one of the Oriental forms of the worship of the forces of nature. The birds' heads may have a religious significance, and possibly the significance which it is said that vultures had in the Syrian nature-worship. These data give some slight presumptions, yet the field for conjecture remains a very wide one, and there is nothing in the buildings to indicate the particular race who erected the Fort and the Temple (if it was a temple). However, the tower bears some resemblance to a tower which appears within a town wall on an ancient coin of the Phœnician city of Byblus, and this coincidence, slight enough, has, in the dearth of other light, been used to support the view that the builders belonged to some Semitic race.

Had we nothing but the ruined walls of 
Zimbabwye, Dhlodhlo, and the other spots where similar ruins have been observed, the problem would be insoluble. We could only say that the existing native races had at some apparently distant time been more civilised than they are now and capable of building walls they do not now build, or else we should suppose that some now extinct race had built these. But there are other facts known to us which suggest, though they do not establish, an hypothesis regarding the early history of the country.

In very remote times there existed, as is known from the Egyptian monuments, a trade from Southeast Africa into the Red Sea. The remarkable sculptures at Deir el Bahari, near Luxor, dating from the time of Queen Hatasu, sister of the great conqueror Thothmes III. (в.C. I600 ?), represent the return of an expedition from a country called Punt, which would appear, from the objects brought back, to have been somewhere on the East African coast. ${ }^{1}$ Much later the Book of Kings (I Kings ix. 26-28; X. I I, I 5, 22) tells us that Solomon and Hiram of Tyre entered into a sort of joint adventure trade from the Red Sea port of Ezion-geber to a country named Ophir, which produced gold. There are other indications that gold used to come from East Africa, but so far as we know it has never been obtained in quantity from any part of the coast between Mozambique and Cape Guardafui. Thus there are grounds for believing that a traffic between

${ }^{1}$ Maspero (Histoire ancienne des Peuples d'Orient, p. 169) conjectures Somaliland. 
the Red Sea and the coast south of the Zambesi may have existed from very remote times. Of its later existence there is of course no doubt. We know from Arabian sources that in the eighth century an Arab tribe defeated in war established itself on the African coast south of Cape Guardafui, and that from the ninth century onward there was a considerable trade between South-east Africa and the Red Sea ports-a trade which may well have existed long before. And when the Portuguese began to explore the coast in 1496 they found Arab chieftains established at various points along it as far south as Sofala, and found them getting gold from the interior. Three things, therefore, are certain - a trade between South-east Africa and the Red Sea, a certain number of Arabs settled along the edge of the ocean, and an export of gold. Now all over Mashonaland and Matabililand ancient gold-workings have been observed. Some are quite modern,- - one can see the wooden supports and the iron tools not yet destroyed by rust, - and it would seem from the accounts of the natives that the mining went on to some small extent down to sixty years ago, when the Matabili conquered the country. Others, however, are, from the appearance of the ground, obviously much more ancient. I have seen some that must have been centuries old, and have been told of others apparently far older, possibly as old as the buildings at Zimbabwye. I was, moreover, informed by $\mathrm{Mr}$. Cecil Rhodes (who is keenly interested in African 
CHAP.

archæology) that he had seen on the high plateau of Inyanga, in eastern Mashonaland, some remarkable circular pits lined with stone, and approached in each case by a narrow subterranean passage, which can best be explained by supposing them to have been receptacles for the confinement of slaves occupied in tilling the soil, as the surrounding country bears marks, in the remains of ancient irrigation channels, of an extensive system of tillage where none now exists. The way in which the stones are laid in these pit-walls is quite unlike any modern Kafir work, and points to the presence of a more advanced race. Putting all these facts together, it has been plausibly argued that at some very distant period men more civilised than the Kafirs came in search of gold into Mashonaland, opened these mines, and obtained from them the gold which found its way to the Red Sea ports, and that the buildings whose ruins we see were their work. How long ago this happened we cannot tell, but if the strangers came from Arabia they must have done so earlier than the time of Mohammed, for there is nothing of an Islamic character about the ruins or the remains found, and it is just as easy to suppose that they came in the days of Solomon, fifteen centuries before Mohammed. Nor can we guess how they disappeared: whether they were overpowered and exterminated by the Kafirs, or whether, as Mr. Selous conjectures, they were gradually absorbed by the latter, their civilization and religion perishing, although the practice 
of mining for gold remained. The occasional occurrence among the Kafirs of faces with a cast of features approaching the Semitic has been thought to confirm this notion, though nobody has as yet suggested that we are to look here for the lost Ten Tribes. Whoever these people were, they have long since vanished. The natives seem to have no traditions about the builders of Zimbabwye and the other ancient walls, though they regard the ruins with a certain awe, and fear to approach them at twilight.

It is this mystery which makes these buildings, the solitary archæological curiosities of South Africa, so impressive. The ruins are not grand, nor are they beautiful; they are simple even to rudeness. It is the loneliness of the landscape in which they stand, and still more the complete darkness which surrounds their origin, their object, and their history, that gives to them their unique interest. Whence came the builders? What tongue did they speak? What religion did they practise? Did they vanish imperceptibly away, or did they fly to the coast, or were they massacred in a rising of their slaves? We do not know ; probably we shall never know. We can only say, in the words of the Eastern poet:

"They came like water, and like wind they went." 


\section{CHAPTER X}

THE KAFIRS: THEIR HISTORY AND INSTITUTIONS

THE curtain rises upon the Kafir peoples when the Portuguese landed on the east coast of Africa in the beginning of the sixteenth century. Arab sheiks then held a few of the coast villages, ruling over a mixed race, nominally Mohammedan, and trading with the Bantu tribes of the interior. The vessels of these Arabs crossed the Indian Ocean with the monsoon to Calicut and the Malabar coast, and the Indian goods they carried back were exchanged for the gold and ivory which the natives brought down. The principal race that held the country between the Limpopo and the Zambesi was that which the Portuguese called Makalanga or Makaranga, and which we call Makalaka. They are the progenitors of the tribes who, now greatly reduced in numbers and divided into small villages and clans, occupy Mashonaland. Their head chief was called the Monomotapa, a name interpreted to mean "Lord of the Mountain" or "Lord of the Mines." This personage was turned by Portuguese grandiloquence into an emperor, and by some Euro- 
pean geographers into the name of an empire; so Monomotapa came to figure on old maps as the designation of a vast territory.

When, in the seventeenth and eighteenth centuries, the Dutch at the Cape began to learn something of the Kafirs who dwelt to the eastward, they found that there was no large dominion, but a great number of petty tribes, mostly engaged in war with one another. Some were half nomad, none was firmly rooted in the soil; and the fact that tribes who spoke similar dialects were often far away from one another, with a tribe of a different dialect living between, indicated that there had been many displacements of population of which no historical record existed. Early in the present century events occurred which showed how such displacements might have been brought about. In the last years of the eighteenth century Dingiswayo, the exiled son of the chief of the Abatetwa tribe, which lived in what is now Zululand, found his way to the Cape, and learned to admire the military organization of the British troops who were then holding the Colony. Returning home and regaining his throne, he began to organise and drill his warriors, who before that time had fought without order or discipline, like other savages. His favourite officer was Tshaka, a young chief, also exiled, who belonged to the then small tribe of Zulus. On the death of Dingiswayo, Tshaka was chosen its chief by the army, and the tribes that had obeyed Dingiswayo were thenceforward known under the 
name of Zulus. Tshaka, who united to his intellectual gifts a boundless ambition and a ruthless will, further improved the military system of his master, and armed his soldiers with a new weapon, a short, broad-bladed spear, fit for stabbing at close quarters, instead of the old light javelin which had been theretofore used. He formed them into regiments, and drilled them to such a perfection of courage that no enemy could withstand their rush, and the defeated force, except such as could escape by fleetness of foot, was slaughtered on the spot. Quarter had never been given in native wars, but the trained valour of the Zulus, and their habit of immediately engaging the enemy hand to hand, not only gave them an advantage like that which suddenly made the Spartan infantry superior to all their neighbours, but rendered their victories far more sanguinary than native battles had previously been. Tshaka rapidly subjected or blotted out the clans that lived near, except the Swazis, a kindred tribe whose difficult country gave them some protection. He devastated all the region round that of his own subjects, while the flight before his warriors of the weaker tribes, each of which fell upon its neighbours with the assagai, caused widespread slaughter and ruin all over Southeast Africa. Natal became almost a desert, and of the survivors who escaped into the mountains, many took to human flesh for want of other food. To the north of the Vaal River a section of the Zulu army, which had revolted under its general, 
Mosilikatze, carried slaughter and destruction through the surrounding country for hundreds of miles, till it was itself chased away beyond the Limpopo by the emigrant Boers, as will be related in the following chapter.

To trace the history of these various native wars would occupy far more space than I can spare. I will sum up their general results.

A new and powerful kingdom, far stronger than any other native monarchy we know to have existed before or since, was formed by the Zulus. It remained powerful under Dingaan (who murdered his half brother Tshaka in I828), Panda (brother of Tshaka and Dingaan), and Cetewayo (son of Panda), till I879, when it was overthrown by the British.

Various offshoots from the Zulu nation were scattered out in different directions. The Matabili occupied Matabililand in 1838 . The Angoni had before that year crossed the Zambesi and settled in Nyassaland, where they are still formidable to their native neighbours and troublesome to the whites.

Kafir tribes from the north-east were chased southward into the mountain country now called Basutoland, most of which had been previously inhabited only by Bushmen, and here the Basuto kingdom was built up out of fugitive clans, by the famous chief Moshesh, between I 820 and 1840 .

Some of the Bechuana tribes were driven from the east into their present seats in Bechuanaland, some few far north-west to the banks of the Zambesi, where Livingstone found them. 
Not only what is now Natal, but most of what is now the Orange Free State, with a part of the Transvaal, was almost denuded of inhabitants. This had the important consequence of inducing the emigrants from Cape Colony, whose fortunes I shall trace in the following chapter, to move toward these regions and establish themselves there.

The Gaza tribe, of Zulu race, but revolters from Tshaka, broke away from that tyrant, and carried fire and sword among the Tongas and other tribes living to the west and northwest of Delagoa Bay. In $I S_{j 3}$ they destroyed the Portuguese garrison there. In I 862 a chief called Mzila became their king. and established his dominion over all the tribes that dwell on the eastern slope of the Quathlamba Mountains, between the Limpopo and the Zambesi. $\mathrm{He}$ and his son Gungunhana, who in 1896 was seized and carried off by the Portuguese, were for a time at the head of the third great native power in South Africa, the other two being that of Cetewayo, which perished in 1879 , and that of Lo Bengula, overthrown in $\mathrm{I}_{9} 9_{3}$. All three chiefs were Zulus in blood. Originally small in number, this race has played by far the greatest part in the annals of the native peoples.

The career of Tshaka has deserved some description, because it changed the face of South Africa in a somewhat similar way, allowing for the difference of scale, to that in which the career of Tshaka's contemporary, Napoleon Bonaparte. changed the face of Europe. But in ${ } S_{3} 6$, eight years after 
Tshaka's death, the white man, who had hitherto come in contact with the Kafirs only on the Zambesi and at a few points on the south-eastern and southern coast, began that march into the interior which has now brought him to the shores of Lake Tanganyika. Thenceforward the wars of the natives among themselves cease to be important. It is their strife with the European conqueror that is of consequence, and the narrative of that strife belongs to the history of the European colonies and republics, which will be given in the two succeeding chapters. This, however, seems the right place for some remarks on the government and customs of the Kafir tribes, intended to explain the conditions under which these tribes have met and attempted to resist the white strangers who have now become their rulers.

The Kafirs were savages, yet not of a low type, for they tilled the soil, could work in metals, spoke a highly developed language, and had a sort of customary law. The south-east coast tribes, Zulus, Pondos, Tembus, Kosas, inhabiting a fairly wellwatered and fertile country, were, as a rule, the strongest men and the fiercest fighters; but the tribes of the interior were not inferior in intellect, and sometimes superior in the arts. Lower in every respect were the west-coast tribes. They dwelt in a poor and almost waterless land, and their blood was mixed with that of Hottentots and Bushmen. In every race the organization was by families, clans, and tribes, the tribe consisting of a number 
of clans or smaller groups, having at its head one supreme chief, belonging to a family whose lineage was respected. The power of the chief was, however, not everywhere the same. Among the Zulus, whose organization was entirely military, he was a despot whose word was law. Among the Bechuana tribes, and their kinsfolk the Basutos, he was obliged to defer to the sentiment of the people, which (in some tribes) found expression in a public meeting where every freeman had a right to speak and might differ from the chief. ${ }^{1}$ Even such able men as the Basuto Moshesh and the Bechuana Khama had often to bend to the wish of their subjects, and a further check existed in the tendency to move away from a harsh and unpopular chief and place one's self under the protection of some more tactful ruler. Everywhere, of course, the old customs had great power, and the influence of the old men who were most conversant with them was considerable. The chief of the whole tribe did not interfere much with affairs outside his own particular clan, and was a more important figure in war-time than during peace. Aided by a council of his leading men, each chief administered justice and settled disputes; and it was his function to allot land to those who asked for a field to till, the land itself belonging to the tribe as a whole. The chief's act gave a title to the piece allotted so long as it was cultivated, for public opinion resented any

1 See further as to this primary assembly the remarks on the Basuto Pitso in the chapter on Basutoland. 
arbitrary eviction ; but pasture-land was open to all the cattle of the clansmen. It was in cattle that the wealth of a chief or a rich man lay, and cattle, being the common measure of value, served as currency, as they serve still among the more remote tribes which have not learned to use British coin. Polygamy was practised by all who could afford it, the wife being purchased from her father with cattle, more or fewer according to her rank. This practice, called lobola, still prevails universally, and has caused much perplexity to the missionaries. Its evil effects are obvious, but it is closely intertwined with the whole system of native society. A chief had usually a head wife, belonging to some important house, and her sons were preferred in succession to those of the inferior wives. In some tribes the chief, like a Turkish sultan, had no regular wife, but only concubines. Among the coast tribes no one, except a chief, was suffered to marry any one of kin to him. There was great pride of birth among the head chiefs, and their genealogies have in not a few cases been carefully kept for seven or eight generations.

Slavery existed among some of the tribes of the interior, and the ordinary wife was everywhere little better than a slave, being required to do nearly all the tillage and most of the other work, except that about the cattle, which, being more honourable, was performed by men. The male Kafir is a lazy fellow who likes talking and sleeping better than continuous physical exertion, and the difficulty of inducing him to work is the chief difficulty which European mine- 
owners in South Africa complain of. Like most men in his state of civilization, he is fond of hunting, even in its lowest forms, and of fighting. Both of these pleasures are being withdrawn from him, the former by the extinction of the game, the latter by the British Government; but it will be long before he acquires the habits of steady and patient industry which have become part of the character of the inhabitants of India.

War was the natural state of the tribes toward one another, just as it was among the Red Indians and the primitive Celts, and indeed generally everywhere in the early days of Europe. Their weapons were the spear or assagai, and a sort of wooden club, occasionally a crescent-shaped battle-axe, and still less frequently the bow. Horses were unknown, for the ox, sheep, goat and dog were over all South Africa the only domesticated quadrupeds. One tribe, however, the Basutos, now breeds horses extensively, and has turned them to account in fighting. The rapid movement of their mounted warriors was one of the chief difficulties the colonial forces had to deal with in the last Basuto war. The courage in war which distinguished the tribes of $\mathrm{Zulu}$ and Kosa race was all the more creditable because it had not, like that of the Mohammedan dervishes of the Sudan, or of Mohammedans anywhere engaged in a jehad, a religious motive and the promise of future bliss behind it. The British army has encountered no more daring or formidable enemies. Nine wars were needed to subjugate the Kafirs 
of the southern coast, although till recently they had few firearms. But the natives had no idea of the tactics needed in facing a civilized foe. As in their battles with the Boers they were destroyed by the fire of horsemen riding up, delivering a volley, and riding off before an assagai could reach them, so in the great war with Cetewayo in I 879 they fought in the open and were mowed down by British volleys ; and in 1893 the Matabili perished in the same way under the fire of riflemen and Maxim guns sheltered behind a laager of wagons.

Religion was a powerful factor in Kafir life; but religion did not mean the worship of any deity, for there was no deity. Still less had it any moral significance. To the Kafirs, as to most savage races, the world was full of spirits-spirits of the rivers, the mountains, and the woods. Most important were the ghosts of the dead, who had power to injure or to help the living, and who were therefore propitiated by offerings at stated periods, as well as on occasions when their aid was specially desired. This kind of worship, the worship once most generally diffused throughout the world, and which held its ground among the Greeks and Italians in the most flourishing period of ancient civilization, as it does in China and Japan to-day, was and is virtually the religion of the Kafirs. It was chiefly rendered to the ghosts of the chiefs, who retained in the spirit world the exceptional importance they had held among the living; and it had much weight in maintaining loyalty to a chief, 
because revolt against him was an insult to a powerful set of ghosts. The ghost dwelt at the spot where the body was buried, and it was therefore at the grave that the offerings, mostly of cakes and Kafir beer, were made. Occasionally animals were killed, not so much by way of sacrifice as for the sake of providing the ghost with a specially precious kind of food, though the two ideas run close together in most primitive worships. ${ }^{1}$ Among the Matabili, for instance, there was once a year a great feast in honour of the king's ancestors who were supposed to come and join in the mirth. It was also to the grave that those who wished to call up the ghost by spells went to effect their nefarious purpose, and the real place of interment of a great chief was for this reason sometimes concealed. I found at Thaba Bosiyo, the famous stronghold of the Basuto chief Moshesh, that his body had been secretly removed from the place where he was buried to baffle the wizards, who might try to use his ghost against the living. The ghost is, of course, apt to be spiteful, that of an uncle (I was told) particularly so; and if he is neglected he is extremely likely to bring some evil on the family or tribe. Sometimes the spirit of an ancestor passes into an animal, and by preference into that of a snake, not that it lives in the snake, but that it assumes this form when it wishes to visit

1 Those who are curious on this subject may consult Mr. Frazer's Golden Bough, and the late Mr. Robertson Smith's Religion of the Semites, where many interesting and profoundly suggestive facts regarding it are collected. 
men. A particular kind of green snake is revered by the Matabili for this reason. And most, if not all, tribes had an animal which they deemed to be of kin to them, and which they called their "siboko," a term apparently corresponding to the totem of the North American Indians. Creatures of this species they never killed, and some tribes took their name from it. Thus the Ba-Taung are the people of the lion; the Ba-Mangwato have the duyker antelope for their totem; and in the Basuto pitso (public meeting) an orator will begin by addressing his audience as "sons of the crocodile." Of human sacrifices there seems to be no trace. Men were killed for all possible reasons, but never as offerings. And, indeed, to have so killed them would have been to treat the ghosts as cannibals, a view foreign to native habits, for though human flesh has been resorted to in times of severe famine, it has never been regularly eaten, and the use of it excites disgust.

Whether the Kafirs had any idea of a supreme being is a question which has been much discussed. In several tribes the word, differently spelled "Umlimo" or "Mlimo" or "Molimo," (said to mean "hidden" or "unseen "), is used to denote either a power apparently different from that of the nature sprites or ghosts of the dead, or else the prophet or soothsayer who delivers messages or oracles supposed to emanate from this power. The missionaries have in their native versions of the Bible used the term to translate the word "God." Sometimes, among the Tongas at least, the word 
tilo (sky) is used to describe a mysterious force; as, for instance, when a man dies without any apparent malady, he is said to be killed by the tilo. ${ }^{1}$ On the whole, after many inquiries from missionaries and others who know the natives well, I was led to the conclusion that the Kafirs have a vague notion of some power transcending that of common ghosts, and able to affect the operations of nature (as, for instance, to send rain), but far too dimly conceived to be properly describable as a divine being. ${ }^{2}$ Or to put the thing in other words, the ordinary and familiar nature-sprites and ghosts of the departed do not exhaust the possibilities of superhuman agency ; for there remains, as among the Athenians whose altar St. Paul found (Acts xvii. 23), an "Unknown God," or rather unknown power, probably associated with the heavens above, whose interference may produce results not attainable through inferior spiritual agencies. One of the difficulties in reaching any knowledge of the real belief of the people is that they are usually examined by leading questions, and are apt to reply affirmatively to whatever the querist puts to them. Their thoughts on these dark subjects are either extremely vague and misty

${ }^{1}$ As in Homer's day sudden deaths were attributed to the arrows of Apollo or Artemis.

2 M. Junod, a Swiss missionary at Delagoa Bay, who made a careful study of the Tonga tribes, told me that they sometimes use the word shikimbo, which properly denotes the ghost of an ancestor, to denote a higher unseen power. And I was informed that the Basutos will pray to the "lesser Molimos," the ghost of their ancestors, to ask the great Molimo to send rain. 
or extremely material; the world of abstract thought, in which European minds have learned to move with an ease and confidence produced by the possession of a whole arsenal of theological and metaphysical phrases, being to them an undiscovered country.

Since there were no deities and no idols, there were no priests; but the want of a priesthood was fully compensated by the presence of wizards, for among the Kafirs, as among other primitive peoples, there was and is an absolute belief in the power of spells, and of sorcery generally. These wizards, like the medicine men among the Red Indians, were an important class, second only to the chiefs. They were not a caste, though very often the son of a wizard would be brought up to the profession. The practitioners were on the lookout for promising boys, and would take and train one to witchcraft, imparting their secrets, which included a remarkable knowledge of the properties of various plants available for poison or healing. Sometimes the wizard acted as a physician; sometimes he would attempt to make rain; sometimes he would profess to deliver messages from the unseen world, and in these cases he might become a terrible power for mischief. Such a revelation made to the Kosa clans on the south coast in $1856-57$, directing them to kill their cattle and destroy their grain, because the ghosts of their ancestors were coming to drive out the whites, led to the death by famine of more than 30,000 people. Such a revelation proceeding from a soothsayer, occasionally called the Mlimo, 
who dwelt in a cavern among granite rocks in the Matoppo Hills at a place called Matojeni, south-east of Bulawayo ${ }^{1}$ (oracles have always tended to come from caves), had much to do with the rising of the Matabili in 1896 . But the most frequent and most formidable work done by the wizard was that of "smelling out" persons who were bewitching others so as to cause sickness or misfortune. In this branch of his profession the wizard often became the engine of the jealousy or rapacity of the chief, who would secretly prompt him to denounce a prominent or a wealthy man. Suspicion being once roused, the victim had little chance: he was despatched, and his property seized by the chief. Witchcraft, and the murders it gave rise to, have been the darkest side of native life. The sorcerer has usually been the enemy of the missionary, who threatens his gains; but his power is now generally declining, and the British government forbids the practice of smelling out witches, as well as many other shocking and disgusting rites which used to accompany the admission of boys and girls to the status of adults, or were practised at sundry festivals. Of the faith in minor and harmless spells one finds instances everywhere. In Matabililand, for instance, a boy was pointed out to me who had just been occupied in putting a charm into the foot-

1 This Mlimo-whether the name is properly applicable to the divinity, whatever it was, or to the prophet, seems doubtfulbelonged to the Makalakas, but was revered by the Matabili who conquered them. 
print of a lion, in order to prevent the unwelcome visitor from returning; and nearly every native wears some kind of amulet. ${ }^{1}$ These beliefs will take a long time to die, but the missionaries have now usually the good sense to see that they do little harm.

As their religious customs were rather less sanguinary than those of the Guinea coast negroes, so the Kafirs themselves were, when the whites first saw them, somewhat more advanced in civilization. Compared with the Red Indians of America, they stood at a point lower than that of the Iroquois or Cherokees, but superior to the Utes or to the Diggers of the Pacific coast. They could work in iron and copper, and had some notions of ornament. Their music is rude, but not wholly devoid of melody, and they use instruments of stone, wood, and iron, by striking which a kind of tune can be played. Some tribes, such as the Tongas, have good voices, and a marked taste for music. They have some simple games, and a folk-lore which consists chiefly in animal tales, resembling those collected by $\mathrm{Mr}$. Harris in his Uncle Remus, save that the hare plays among the Bantu peoples the part of Br'er

1 It need hardly be said that they have a full belief in the power of certain men to assume the forms of beasts. I was told that a leading British official was held to be in the habit, when travelling in the veldt, of changing himself, after his morning tub, into a rat and creeping into his waggon, whence he presently re-emerged in human shape. 
Rabbit. ${ }^{1}$ To poetry, even in its most rudimentary forms, they do not seem to have attained. Yet they are by no means wanting in intelligence, and have, with less gaiety, more sense of dignity and more persistence in their purposes than the Guinea negro.

When the Portuguese and Dutch first knew the Kafirs, they did not appear to be making any progress toward a higher culture. Human life was held very cheap; women were in a degraded state, and sexual morality at a low ebb. Courage, loyalty to chief and tribe, and hospitality were the three prominent virtues. War was the only pursuit in which chieftains sought distinction, and war was mere slaughter and devastation, unaccompanied by any views of policy or plans of administration. The people were-and indeed still are-passionately attached to their old customs, which even a king rarely ventured to disturb (though Tshaka is said to have abolished among his subjects the rite of circumcision, which is generally practised by the Kafirs); and it was probably as much the unwillingness to have their customs disturbed as the apprehension for their land that made many of the tribes oppose to the advance of the Europeans so obstinate a resistance. Though they feared the

${ }^{1}$ Several collections have been made of these tales. The first is that of Bishop Callaway, the latest that of my friend Mr. Jacottet, a Swiss missionary in Basutoland, who has published a number of Basuto stories in his Contes Populaires des Bassoutos, and of Barotse stories in another book. 
firearms of the whites, whom they called wizards, it was a long time before they realized their hopeless inferiority, and the impossibility of prevailing in war. Their minds were mostly too childish to recollect and draw the necessary inferences from previous defeats, and they never realized that the whites possessed beyond the sea an inexhaustible reservoir of men and weapons. Even the visit of Lo Bengula's envoys to England in I89I, when they were shown all the wonders of London, in order that through them the Matabili nation might be deterred from an attack on the whites, failed to produce any effect upon the minds of the young warriors, who were fully persuaded that they could destroy the few strangers in their country as easily as they had overthrown the Mashonas. The only chiefs who seem to have fully grasped the relative strength of the Europeans, and thus to have formed schemes of policy suitable to their inferior position, were Moshesh, who profited by the advice of the French missionaries, and Khama, who was himself a Christian and the pupil of missionaries. Nor did any chief ever rise to the conception of forming a league of blacks against whites.

The natives, as we shall see, have had harsh treatment from the Europeans. Many unjust things, many cruel things, many things which would excite horror if practised in European warfare, have been done against them. But whoever tries to strike the balance of good and evil due to the coming of the whites must remember 
what the condition of the country was before the whites came. As between the different tribes there was neither justice nor pity, but simply the rule of the strongest, unmitigated by any feeling of religion or morality. In war non-combatants as well as combatants were ruthlessly slaughtered, or reserved only for slavery; and war was the normal state of things. Within each tribe a measure of peace and order was maintained. But the weak had a hard time, and those who were rich, or had roused the enmity of some powerful man, were at any moment liable to perish on the charge of witchcraft. In some tribes, such as the Matabili, incessant slaughter went on by the orders of the king. Nothing less than the prolific quality of the race could have kept South Africa well peopled in the teeth of such a waste of life as war and murder caused.

Of the character of the individual native as it affects his present relations with the whites and the probable future of the race, I shall have to speak in a later chapter (Chapter XXI), as also of the condition and prospects of the Christian missions which exist among them, and which form the main civilizing influence now at work. 


\section{CHAPTER XI}

THE EUROPEANS IN SOUTH AFRICA TILL I 854

It is no less true of South Africa than it is of the old countries of Europe that to understand the temper of the people, the working of their government, the nature of the political problems which they have to solve, one must know something of their history. South Africa has had a great deal of history, especially in the present century, and there are few places in which recollections of the past are more powerful factors in the troubles of the present. In the short sketch I propose to give I shall advert only to the chief events, and particularly to those whose importance is still felt and which have done most to determine the relations of the European races to one another. The constitutional and parliamentary history of the two British colonies and the two Boer republics has been short and not specially interesting. The military history has been on a small scale. The economic and industrial history has been simple and remarkable only so far as the mines are concerned. But the history of the dealings of the white races with one another and 
with the blacks is both peculiar and instructive, and well deserves a fuller narrative and more elaborate treatment than I have space to give.

Four European races have occupied the country. Of those, however, who came with Vasco da Gama from Lisbon in 1497 we shall have little to say, and of those who followed Herr Lüderitz from Bremen in 1883 still less. The interest of the tale lies in the struggles of two branches of the same Low-German stock, the Dutch and the English.

The first to appear on the scene were the men of Portugal, then in the fresh springtime of its power and with what seemed a splendid career of discovery and conquest opening before it. ${ }^{1}$ Bartholomew Diaz, whose renown has been unjustly obscured by that of Vasco da Gama, discovered the Cape of Storms, as he called it, - the name of Good Hope was given by King John II.,-in I486, and explored the coast as far as the mouth of the Great Fish River. In $1497-98 \mathrm{Da}$ Gama, on his famous voyage to India, followed the southern and eastern coast to Melinda; and in 1502 , on his second voyage, after touching at Delagoa Bay, he visited Sofala, which was then the port to which most of the gold and ivory came from the interior. Here he found Arabs established in the town, as they were in other maritime trading places all the way north to Mombasa. At what date they first settled

1 The best recent account of the doings of the Portuguese is to be found in Dr. Theal's book, The Portuguese in South Africa, published in 1896 . 
there is unknown; probably they had traded along the coast from times long before Mohammed. They were superior to the native blacks, though mixed in blood, but of course far inferior to the Portuguese, who overthrew their power. In 1505 the Portuguese built a fort at Sofala, and from there and several other points along the coast prosecuted their trade with the inland regions, using the conquered Arabs as their agents. For a century they remained the sole masters not only of the South-east African seaboard, but of the Indian Ocean, no vessel of any other European country appearing to dispute their pre-eminence. They might, had they cared, have occupied and appropriated the whole southern half of the continent ; but in the sixteenth century it was not of colonization, nor even so much of conquest, that monarchs, governors, and navigators thought, but of gold. Portugal had no surplus population to spare for settling her new territories, and-not to speak of Brazil-she had a far richer trade to develop in western India than anything which Africa could offer. It may now excite surprise that she should have taken no step to claim the long stretch of country whose shores her sailors had explored, from the mouth of the Orange River on the west to that of the Limpopo on the east. But there was no gold to be had there, and a chance skirmish with the Hottentots in Table Bay, in which the viceroy D'Almeida, returning from India, was killed in $15 \mathrm{IO}$, gave them a false notion of the danger to be feared from that people, who were in 
reality one of the weakest and least formidable among African races.

Accordingly, the Portuguese, who might have possessed themselves of the temperate and healthy regions which we now call Cape Colony and Natal, confined their settlements to the malarious country north of the tropic of Capricorn. Here they made two or three attempts, chiefly by moving up the valley of the Zambesi, to conquer the native tribes, or to support against his neighbours some chieftain who was to become their vassal. Their numbers were, however, too small, and they were too feebly supported from home, to enable them to secure success. When they desisted from these attempts, their missionaries, chiefly Dominican friars, though some Jesuits were also engaged in the work, maintained an active propaganda among the tribes, and at one time counted their converts by thousands. Not only missionaries, but small trading parties, penetrated the mysterious interior; and one or two light cannons, as well as articles which must have come to Africa from India, such as fragments of Indian and Chinese pottery, have been found many hundred miles from the sea. ${ }^{1}$

1 I have heard from Lord Wolseley that in his expedition against Sikukuni, a Kafir chief in the north-east of the Transvaal, he was told by a German trader who acted as guide that the natives had shown to him (the trader) fragments of ancient European armour which were preserved in a cave among the mountains. The natives said that this armour had been worn by white men who had come up from the sea many, many years ago, and whom their own ancestors had killed. 
But on the whole the Portuguese exerted very little permanent influence on the country and its inhabitants. The missions died out, most of the forts crumbled away or were abandoned, and all idea of further conquest had been dropped before the end of last century. There were, indeed, two fatal obstacles to conquering or civilizing work. One was the extreme unhealthiness both of the flat country which lies between the sea and the edge of the great interior plateau, and of the whole Zambesi Valley, up which most of the attempts at an advance had been made. Fever not only decimated the expeditions and the garrisons of the forts, but enervated the main body of settlers who remained on the coast, soon reducing whatever enterprise or vigour they had brought from Europe. The other was the tendency of the Portuguese to mingle their blood with that of the natives. Very few women were brought out from home, so that a mixed race soon sprang up, calling themselves Portuguese, but much inferior to the natives of Portugal. The Portuguese, even more than the Spaniards, have shown both in Brazil and in Africa comparatively little of that racial contempt for the blacks, and that aversion to intimate social relations with them, which have been so characteristic of the Dutch and the English. There have, of course, been a good many mulattos born of Dutch fathers in Africa, as of Anglo-American fathers in the West Indies and in the former slave States of North America. But the Dutch or English mulatto was 
almost always treated as belonging to the black race, and entirely below the level of the meanest white, whereas among the Portuguese a strong infusion of black blood did not necessarily carry with it social disparity. ${ }^{1}$

In the beginning of the seventeenth century the Dutch, prosecuting their war against the Spanish monarchy, which had acquired the crown of Portugal in $158 \mathrm{I}$ and held it till 1640 , attacked the Portuguese forts on the East African coast, but after a few years abandoned an enterprise in which there was little to gain, and devoted their efforts to the more profitable field of the East Indies. With this exception, no European power troubled the Portuguese in Africa. They had, however, frequent conflicts with the natives, and in 1834 were driven from their fort at Inhambane, between Sofala and Delagoa Bay, and in 1836 from Sofala itself, which, however, they subsequently recovered. It was not till the progress of inland discovery, and especially the establishment of a Boer republic in the Transvaal had made the coast seem valuable, that two new and formidable rivals appeared on the scene.

Under the combined operation of these causes such power as Portugal possessed on this coast declined during the seventeenth and eighteenth centuries. Except on the deadly banks of the

1 Maceo, the well-known leader of the Cuban insurgents who was killed in 1896 , was a half-breed, in whose band there were plenty of pure whites. In no Southern State of North America would white men have followed a mulatto. 
Zambesi, she never had a permanent settlement more than fifty miles from the sea, and very few so far inland. The population that spoke Portuguese and professed Christianity did not exceed a few thousands, and of these the large majority were at least half Kafir in blood. It became plain that such life and force as the nation once possessed had, at any rate in Africa, died out, and that if ever the continent was to be developed it would not be by the race that had first explored it. Here, therefore, we may leave the eastern coast and the feeble settlers who shivered with ague in its swamps, and turn our eyes to the far south, where a new and more vigorous race began, a century and a half after the time of Vasco da Gama, to lay the foundations of a new dominion.

The first Teutonic people that entered the African continent were the Vandals in the fifth century. They came across the Straits of Gibraltar as conquerors, but they soon established a powerful fleet and acquired a maritime empire in the western Mediterranean. The second band of Teutons to enter were the Dutch. They were already a sea power active in the far East, whither they had been led by their war with Spain. But they did not come as conquerors, nor even as settlers intending to build up a colonial community. They came to establish a place of call for their vessels trading to India, where fresh water and vegetables might be obtained for their crews, who suffered terribly from scurvy on the voyage of 
six months or more from the Netherlands to the ports of Farther India. From the early years of the seventeenth century both Dutch and English vessels had been in the habit of putting in to Table Bay to refit and get fresh water. Indeed, in 1620 two English commanders had landed there and proclaimed the sovereignty of King James I., though their action was not ratified either by the king or by the English East India Company. In I648 a shipwrecked Dutch crew spent six months in Table Valley, behind the spot where Cape Town now stands, and having some seeds with them, planted vegetables and got a good crop. They represented on their return to Holland the advantages of the spot, and in $165_{2}$ three vessels despatched by the Dutch East India Company disembarked a body of settlers, under the command of Jan van Riebeek, who were directed to build a fort and hospital, and, above all, to raise vegetables and obtain from the Hottentots supplies of fresh meat for passing ships. It is from these small beginnings of a kitchengarden that Dutch and British dominion in South Africa has grown up.

The history of this Dutch settlement presents a singular contrast to that of the Portuguese. During the first quarter of a century the few settlers kept themselves within the narrow limits of the Cape peninsula. In I680 an outlying agricultural community was planted at Stellenbosch, twenty-five miles from Cape Town, but not till the end of the century was the first range of mountains crossed. 
Meantime the population began to grow. In 1658 the first slaves were introduced,-West African negroes,- - deplorable step, which has had the result of making the South African whites averse to open-air manual work and of practically condemning South Africa to be a country of black labour. Shortly afterwards the Company began to bring in Asiatic convicts, mostly Mohammedan Malays, from its territories in the East Indian Archipelago. These men intermarried with the female slaves, and to a less extent with Hottentot women, and from them a mixed coloured race has sprung up, which forms a large part of the population of Cape Town and the neighbouring districts. The influx of these inferior elements was balanced by the arrival in 1689 of about three hundred French Huguenots, a part of those who had taken refuge in Holland after the revocation of the Edict of Nantes by Louis XIV. They were persons of a high stamp, more intelligent and educated than most of the previous settlers had been, and they brought with them a strong attachment to their Protestant faith and a love of liberty. From them many of the best colonial families are sprung. At first they clung to their language, and sought to form a distinct religious community; but they were ultimately compelled to join the Dutch Reformed Church, and the use of French was forbidden in official documents or religious services. Before the middle of the eighteenth century that language had disappeared and the newcomers had 
practically amalgamated with their Dutch neighbours. The Company's government was impartially intolerant, and did not until i 780 permit the establishment of a Lutheran church, although many German Lutherans had settled in the country.

From the time when the settlers began to spread out from the coast into the dry lands of the interior a great change came upon them, and what we now call the distinctive South African type of character and habits began to appear. The first immigrants were not, like some of the English settlers in Virginia, men of good social position in their own country, attached to it by many ties, nor like the English settlers in the New England colonies, men of good education and serious temper, seeking the freedom to worship God in their own way. They came from the humbler classes, and partly because they had few home ties, partly because the voyage to Holland was so long that communication with it was difficult, they maintained little connection with the mother country and soon lost their feeling for it. The Huguenot immigrants were more cultivated, and socially superior to the rude adventurers who had formed the bulk of the Dutch settlers, but they had of course no home country to look to. France had cast thern out; Holland was alien in blood and speech. So it befell that of all the colonists that Europe had sent forth since the voyage of Columbus, the South African whites were those who soonest lost their bond with Europe, and were the first set of emigrants to feel themselves a new people, whose 
true home lay in the new land they had adopted. Thus early in South African annals were the foundations laid of what we now call the Africander sentiment-a sentiment which has become one of the main factors in the history of the country.

Nor was this all. When the comparatively small area of fertile land which could be cultivated without irrigation had been taken up, the keeping of cattle suggested itself as an easy means of livelihood. The pasture, however, was so thin that it was necessary to graze the cattle over wide stretches of ground, and the farther they went into the interior the scantier was the pasture and the larger therefore did the area of land become over which a farmer let his oxen or sheep run. This process of extending cattle-farms-if farms they can be called-over the interior was materially accelerated through the destruction of the nearer Hottentot tribes by the frightful outbreak of smallpox which began in A.D. I 7 I 3 , followed by another not less virulent in I 755 . The Europeans suffered severely from it, the negroes, slave and free, still more, but the Hottentots most of all. In fact, it cleared them away from all the southern and western parts of the Colony and left these regions open to Europeans. Only the Bushmen remained, whose more solitary life gave them comparative immunity from contagion. Thus from the beginning of the eighteenth century, and during the whole of it, there was a constant dispersion of settlers from the old nucleus into the circumjacent wilderness. They were required to pay a sum 
amounting to five pounds a year for the use of three thousand morgen (a little more than six thousand acres) of grazing ground, and were accustomed at certain seasons to drive their herds up into the deserts of the Karroo for a change of feed, just after the time when the summer rains stimulate the scrubby vegetation of that desert region. These settlers led a lonely and almost nomadic life. Much of their time was passed in their tent-wagons, in which, with their wives and children, they followed the cattle from spot to spot where the pasture was best. They became excellent marksmen and expert in the pursuit of wild beasts. Some made a living by elephant-hunting in the wilderness, and those who tended cattle learned to face the lion. They were much molested by the Bushmen, whose stealthy attacks and poisoned arrows made them dangerous enemies, and they carried on with the latter a constant war, in which no quarter was given. Thus there developed among them that courage, self-reliance, and passion for independence which are characteristic of the frontiersman everywhere, coupled with a love of solitude and isolation which the conditions of western America did not produce. For in western America the numbers and ferocity of the Red Indians, and those resources of the land which encouraged the formation of agricultural and timber-producing communities, made villages follow the march of discovery and conquest, while in pastoral Africa villages were few and extremely small. Isolation and the wild life these ranchmen led soon 
told upon their habits. The children grew up ignorant; the women, as was natural where slaves were employed, lost the neat and cleanly ways of their Dutch ancestors; the men were rude, bigoted, indifferent to the comforts and graces of life. But they retained their religious earnestness, carrying their Bibles and the practice of daily family worship with them in their wanderings; and they retained also a passion for freedom which the government vainly endeavoured to restrain. Though magistrates, called landdrosts, were placed in a few of the outlying stations, with assessors taken from the people, called heemraden, to assist them in administering justice, it was found impossible to maintain control over the wandering cattle-men, who, from their habit of "trekking" from place to place, were called Trek Boers. The only organization that brought them together was that which their ceaseless strife with the Bushmen enjoined. Being all accustomed to the use of arms, they formed war-parties, which from time to time attacked and rooted out the Bushmen from a disturbed area ; and the government recognized these military needs and methods by appointing field-commandants to each district, and subordinate officers, called field-cornets, to each subdistrict. These functionaries have become the basis of the system of local government among the South African Dutch, and the war-bands, called commandos, have played a great part in the subsequent military history of the country.

The eastward progress of expansion presently 
CHAP.

brought the settlers into contact with more formidable foes in the Bantu tribes, who dwelt beyond the Great Fish River. In I779 some Kafir clans of the Kosa race crossed that river and drove off the cattle of the farmers to the west of it, and a war, the first of many fiercely fought Kafir wars, followed, which ended in the victory of the colonists.

All this while the Colony had been ruled by the Dutch East India Company through a governor and council, appointed by the directors in Holland, and responsible to them only-a system roughly similar to that which the English established in India during the eighteenth century. The administration was better or worse according to the character and capacity of the governor for the time being, but it was on the whole unpopular with the colonists, not merely because they were excluded from all share in it (except to some small extent in the courts of justice), but also because the Company kept in its own hands a monopoly of the trade, and managed trade with a view to its own commercial interests rather than to those of the community. Thus discontent grew, and this discontent was one of the causes which led to the dispersion of the people into the wilderness, whose remoteness secured to them a practical freedom. In I779 disaffection had been so much stimulated by the maladministration of a weak governor, and by the news of the revolt of the American colonies against Great Britain, that delegates were sent to Holland to demand redress for their commercial and other grievances, as well 
as a share in the government of the Colony. The Company was by this time in financial straits, and less powerful with the States-general of the Netherlands than it had formerly been. Long negotiations followed, reforms were promised, and at last, in I792, two commissioners were sent out to investigate and frame measures of reform. The measures they promulgated were, however, deemed inadequate by the more ardent spirits, and by those especially who dwelt in the outlying districts, where the government had exerted, and could exert, little control. In 1795, first at Graaf-Reinet and then at Swellendam, the people rose in revolt, not, as they stated, against the mother country, but against the Company. They turned out the landdrosts, and set up miniature republics, each with a representative assembly.

It would not have been difficult for the government to have reduced these risings by cutting off supplies of food. But now South Africa was suddenly swept into the great whirlpool of European politics, and events were at hand which made these petty local movements insignificant, save in so far as they were evidences of the independent spirit of the people.

From I757, when the battle of Plassey was fought, the English power in India had been rapidly growing, and the Cape, which they had not cared to acquire in 1620 , had now become in their eyes a station of capital importance. When war broke out between Britain and Holland in $178 \mathrm{I}$, the English 
CHAP.

had attempted to seize the Colony, but retired when they found a strong French force prepared to aid the Dutch in its defence. Now they were again at war with Holland, which, overrun by the armies of revolutionary France, had become the Batavian Republic. In I795 an English expedition, bearing orders from the Stadholder of the Netherlands, then a refugee in England, requiring the Company's officers to admit them, landed at Simon's Bay, and after some slight resistance obliged Cape Town and its castle to capitulate. Within a few months the insurgents at Swellendam and Graaf-Reinet submitted, and British troops held the Colony till I8o2, when it was restored to the Batavian Republic on the conclusion of the peace of Amiens. Next year, however, war broke out afresh, and the English government, feeling the extreme importance, in the great struggle which they were waging with Napoleon, of possessing a naval stronghold as a half-way house to India, resolved again to occupy the Cape. In I806 a strong force was landed in Table Bay, and after one engagement the Dutch capitulated. In I8I4 the English occupation was turned into permanent sovereignty by a formal cession of the Colony on the part of the then restored Stadholder, who received for it and certain Dutch possessions in South America the sum of $£ 6,000$,000.

The European population of the Colony, which was thus finally transferred to the rule of a foreign though a cognate nation, consisted in 1806 of about 27,000 persons, mostly of Dutch, with a smaller 
number of German or French descent. They had some 30,000 black slaves, and of the aboriginal Hottentots about I 7,000 remained. Nearly all spoke Dutch, or rather the rude local dialect into which the Dutch of the original settlers (said to have been largely Frieslanders), had degenerated. The descendants of the Huguenots had long since lost their French.

No people finds it agreeable to be handed over to the government of a different race, and the British administration in the Colony in those days was, though restrained by the general principles of English law, necessarily autocratic, because representative institutions had never existed at the Cape. Still things promised well for the peace and ultimate fusion of the Dutch and English races. They were branches of the same LowGerman stock, separated by fourteen hundred years of separate history, but similar in the fundamental bases of their respective characters. Both were attached to liberty, and the British had indeed enjoyed at home a much fuller measure of it than had the Dutch in the settled parts of the Colony. Both professed the Protestant religion, and the Dutch were less tolerant toward Roman Catholics than the English. The two languages retained so much resemblance that it was easy for an Englishman to learn Dutch and for a Dutchman to learn English. An observer might have predicted that the two peoples would soon, by intercourse and by intermarriage, melt into one, as Dutch and English 
had done in New York. For a time it seemed as if this would certainly come to pass. The first two British governors were men of high character, whose administration gave little ground for complaint to the old inhabitants. The Company's restrictions on trade had been abolished, and many reforms were introduced by the new rulers. Schools were founded, the administration of justice was. reorganised under new courts, the breed of cattle and horses was improved, the slave-trade was forbidden, and missions to the natives were largely developed. Meanwhile local institutions were scarcely altered, and the official use of the Dutch language was maintained. The Roman-Dutch law, which had been in force under the Company's rule, was permitted to remain, and it is to-day the common law of all the British colonies and territories, as well as of the Boer republics, in South Africa. Intermarriage began, and the social relations of the few English who had come in after 1806 , with the many Dutch were friendly. In I 820 the British government sent out about five thousand emigrants from England and Scotland, who settled in the thinly occupied country round Algoa Bay on the eastern border of the Colony; and from that time on there was a steady, though never copious, influx of British settlers, through whose presence the use of the English language increased, together with a smaller influx of Germans, who soon lost their national individuality and came to speak either English or the local Dutch. 
Before long, however, this fair promise of peace and union was overclouded, and the causes which checked the fusion of the races in the Colony, and created two Dutch Republics beyond its limits, have had such momentous results that they need to be clearly stated.

'The first was to be found in the character of the Dutch population. They were farmers, a few dwelling in villages and cultivating the soil, but the majority stock-farmers, living scattered over a wide expanse of country, for the thinness of the pasture had made and kept the stock-farms very large. They saw little of one another, and nothing of those who dwelt in the few towns which the Colony possessed. They were ignorant, prejudiced, strongly attached to their old habits, impatient of any control. The opportunities for intercourse between them and the British were thus so few that the two races acquired very little knowledge of one another, and the process of social fusion, though easy at Cape Town and wherever else the population was tolerably dense, was extremely slow over the country at large. A deplorable incident which befell on the eastern border in 1815 did much to create bad blood. A slight rising, due to the attempted arrest of a farmer on a charge of maltreating his native servant, broke out there. It was soon suppressed, but of the prisoners taken six were condemned to death and five were hanged. This harsh act, which was at the time justified as a piece of "necessary firmness," produced wide-spread and bitter resentment, and 
the mention of Slagter's Nek continued for many years to awaken an outburst of anti-British feeling among the Boers.

A second cause was the unwisdom of the British authorities in altering (between 1825 and 1828 ) the old system of local government (with the effect of reducing the share in it which the citizens had enjoyed), and in substituting English for Dutch as the language to be used in official documents and legal proceedings. This was a serious hardship, for probably not more than one-sixth of the people understood English. A third source of trouble arose out of the wars with the Kafirs on the eastern border. Since the first hostilities of I 779 there had been four serious struggles with the tribes wholived beyond the Fish River, and in 1834 a host of savages suddenly burst into the Colony, sweeping off the cattle and killing the farmers. After some hard fighting the Kafirs were reduced to sue for peace, and compelled by the governor to withdraw beyond the Keiskama River. But the British government at home, considering that the natives had been ill-treated by the colonists, and in fact provoked to war, overruled the governor, and allowed them to return to their old seats, where they were, no doubt, a source of danger to the border farmers. Thinking the home authorities either weak or perverse, the farmers bitterly resented this action, and began to look on the British Colonial Office as their enemy.

But the main grievance arose out of those native 
and colour questions which have ever since continued to trouble South Africa. Slavery had existed in the Colony since 1658 , and had produced its usual consequences, the degradation of labour, and the notion that the black man has no rights against the white. In I 737 the first Moravian mission to the Hottentots was frowned upon, and a pastor who had baptized natives found himself obliged to return to Europe. The current of feeling in Europe, and especially in England, which condemned the "domestic institution" and sought to vindicate the human rights of the negro, had not been felt in this remote corner of the world, and from about i 8 ro onward the English missionaries gave intense offence to the colonists by espousing the cause of the natives and the slaves, and reporting every case of cruel or harsh treatment which came to their knowledge. It is said that they often exaggerated, or made charges on insufficient evidence, and this is likely enough. But it must also be remembered that they were the only protectors the blacks had; and where slavery exists, and a weak race is dominated by a strong one, there are sure to be many abuses of power. When, in I828, Hottentots and other free coloured people were placed by governmental ordinance on an equal footing with whites as regards private civil rights, the colonists were profoundly aisgusted, and their exasperation was increased by the enactment of laws restraining their authority over their slaves, as well as by the charges of ill-treating the natives which continued to be brought against them by the missionaries.

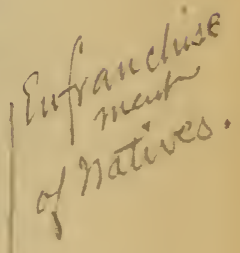


Finally, in 1834 , the British Parliament passed a statute emancipating the slaves throughout all the British colonies, and awarding a sum of twenty million pounds sterling as compensation to the slave-owners. The part of this sum allotted to Cape Colony (a little more than three million sterling) was considerably below the value of the slaves (about 39,000) held there, and as the compensation was made payable in London, most slave owners sold their claims at inadequate prices. Many farmers lost the bulk of their property, and labour became in many districts so scarce that agriculture could hardly be carried on. The irritation produced by the loss thus suffered, intensifying the already existing discontent, set up a ferment among the Dutch farmers. Their spirit had always been independent, and the circumstances of their isolated life had enabled them to indulge it. Even under the government of their Dutch kinsfolk they had been restless, and now they received, as they thought, one injustice after another at the hands of alien rulers. To be watched and denounced by the missionaries, to have black people put on a level with them, to lose the fruits of their victory over the Kafirs-all these things had been bad enough. Now, however, when their property itself was taken away and slavery abolished on grounds they could neither understand nor approve, they determined to endure no longer, and sought for some means of deliverance. Rebellion against so strong a power as that of Britain was evidently foredoomed to failure. 
But to the north and east a great wild country lay open before them, where they could lead that solitary and half-nomadic life which they loved, preserve their old customs, and deal with the natives as they pleased, unvexed by the meddlesome English. Accordingly, many resolved to quit the Colony altogether and go out into the wilderness. They were the more disposed to this course, because they knew that the wars and conquests of Tshaka, the ferocious Zulu king, had exterminated the Kafir population through parts of the interior, which therefore stood open to European settlement. Thus it was that the Great Trek, as the Dutch call it,--the great emigration, or secession, as we should say,of the Dutch Boers began in I8 36 , twenty-five years before another question of colour and slavery brought about a still greater secession on the other side of the Atlantic.

If the reader will here refer to the map, and measure from Cape Town a distance of about four hundred and fifty miles to the east (to the mouth of the Great Fish River), and about the same distance to the north-north-east (to where the towns of Middelburg and Colesberg now stand), he will obtain a pretty fair idea of the limits of European settlement in 1836 . The outer parts of this area toward the north and east were very thinly peopled, and beyond them there was a vast wilderness, into which only a few hunters had penetrated, though some farmers had, during the last decade or two, been accustomed to drive their flocks and herds 
into the fringe of it after the rains, in search of fresh pastures. The regions still farther to the north and east were almost entirely unexplored. They were full of wild beasts, and occupied here and there by native tribes, some, like the various branches of the $Z$ ulu race, eminently fierce and warlike. Large tracts, however, were believed to be empty and desolate, owing to the devastations wrought during his twenty years of reign by Tshaka, who had been murdered eight years before. Of the existence of mineral wealth no one dreamed. But it was believed that there was good grazing-land to be found on the uplands that lay north of the great Quathlamba Range (where now the map shows the Orange Free State and the Transvaal Republic). More to the south lay the territory we now call Natal. It was described by those very few persons who had explored it as fertile and well watered, a country fit both for tillage and for pasture; but wide plains and high mountains had to be crossed to reach it by land from the north-west, and close to it on the north-east was the main body of the Zulu nation, under King Dingaan, the brother and successor of Tshaka.

Into this wilderness did the farmers set forth, and though some less laudable motives may have been mingled with the love of independence and the resentment at injustice which mainly prompted their emigration, it is impossible not to admire their strenuous and valiant spirit. They were a religious people, knowing no book but the Bible, and the 
deemed themselves, like many another religious people at a like crisis of their fortunes, to be under the special protection of Heaven, as was Israel when it went out of Egypt into a wilderness not so vast nor so full of perils as was that which the Boers were entering. Escaping from a sway which they compared to that of the Egyptian king, they probably expected to be stopped or turned back. But Pharaoh, though he had turned a deaf ear to their complaints, was imbued with the British spirit of legality. He consulted his attorney-general, and did not pursue them. The colonial government saw with concern the departure of so many useful subjects. But it was advised that it had no legal right to stop them, so it stood by silently while party after party of emigrants-each householder with his wife and his little ones, his flocks and his herds and all his goods-took its slow way from the eastern or northern parts of the Colony, up the slopes of the coast range, and across the passes that lead into the high plateau behind. Within two years from 6,000 to 10,000 persons set forth. They travelled in large covered wagons drawn by ten or twelve yoke of oxen, and they were obliged to travel in parties of no great size, lest their cattle should exhaust the pasture along the track they followed. There was, however, a general concert of plan among them, and most of the smaller groups united at spots previously fixed upon for a rendezvous. All the men were armed, for the needs of defence against the Bushmen, and the passion for killing 
game, had made the farmers expert in the use of the rifle. As marksmen they were unusually steady and skilful, and in the struggles that followed nothing but their marksmanship saved them. Few to-day survive of those who took part in this Great Trek, but among those few is Paul Kruger, now President of the South African Republic, who followed his father's cattle as they were driven forward across the prairie, being then a boy of ten.

I have not space to tell, save in the briefest outline, the striking and romantic story of the wanderings of the emigrant Boers and their conflicts with the native tribes. The first party, like the first host of Crusaders that started for the East in the end of the eleventh century, perished miserably. It consisted of ninety-eight persons travelling with thirty wagons. They penetrated far to the north-east, into what is now the territory of the Transvaal Republic. Some were cut off by the natives; some, reduced to a mere handful by fever and by the loss of their cattle,-for they had ventured into the unhealthy lower country to the south-east of the mountains, where the tsetse-fly abounds,-made their way to the coast at Delagoa Bay. Another party, formed by the union of a number of smaller bodies at Thaba 'Ntshu, a rocky peak in the Orange Free State, visible on the eastern horizon from the present town of Bloemfontein, advanced thence to the north, and presently came in contact with a redoubtable branch of the Zulu race, famous in later history under the 
name of Matabili. This tribe was then ruled by the chief Umzilikazi, or Mosilikatze, a warrior of great energy and talent. He had been one of Tshaka's favourite generals, but, having incurred that king's displeasure, had fled, about A.D. I8I7, with his regiment to the northwest, and established his headquarters near a place called Mosega (between Pretoria and Mafeking), in what is now the Transvaal Republic. Thence he raided and massacred the Bechuanas and other tribes of this region, though himself unable to withstand the main Zulu nation, which, under Dingaan, was living farther to the south. The Matabili provoked war by falling upon and destroying a detachment of the emigrants. Intruders the latter doubtless were, but, as the Matabili themselves had slaughtered without mercy the weaker Kafir tribes, the Boers might think they need not feel any compunction in dealing out the like measure to their antagonists. And, in point of fact, the emigrants seem all through to have treated the natives much as Israel treated the natives of Canaan, and to have conceived themselves to have Old Testament authority for occupying the territories of the heathen, and reducing them by the sternest methods to serfdom or submission. Here they had an unprovoked massacre to avenge, and they showed equal promptitude and courage. Pouncing upon Mosilikatze, they defeated his vastly superior force with so great a slaughter that he fled northwestward far away beyond the Limpopo River, and fell like a thunder-bolt upon the tribes who dwelt 
between that stream and the Zambesi, killing many and making slaves of the rest. Here, with the king's kraal of Buluwayo for its capital, was established the kingdom of the Matabili, which remained as a terror to its neighbours till, in its turn, destroyed by Dr. Jameson and the British South Africa Company in I893. It was a curious chain of events that brought fire and slaughter so suddenly, in 1837 , upon the peoples of the Zambesi Valley. As the conflicts of nomad warriors along the great wall of China in the fourth century of our era set a-going a movement which, propagated from tribe to tribe, ended by precipitating the Goths upon the Mediterranean countries, and brought Alaric to the Salarian Gate of Rome, so the collapse of the French monarchy, inducing the Revolution and the consequent war with England, carried the English to the Cape, brought the Boers into collision with the Matabili, and at last hurled the savage host of Mosilikatze on the helpless Makalakas.

The defeat and expulsion of the Matabili left the vast territories between the Orange River and the Limpopo in the hands of the Boer immigrants. Within these territories, after much moving hither and thither, those small and rude communities began to grow up which have ripened, as we shall presently see, into the two Dutch republics of our own time. But, meanwhile, a larger and better organized body of Boers, led by a capable and much-respected man named Pieter Retief, marched first eastward and then southward across the Quathlamba watershed, 
and descended from the plateau into the richer and warmer country between those mountains and the Indian Ocean. This region had been in 1820 almost depopulated by the invasions of Tshaka, and now contained scarce any native inhabitants. A few Englishmen had since 1824 been settled on the inlet then called Port Natal, where now the prosperous town of Durban lies beneath the villas and orchards of Berea, and (having obtained a cession of the maritime strip from King Tshaka) were maintaining there a sort of provisional republic. In 1835 they had asked to be recognized as a colony under the name of Victoria, in honour of the young princess who two years afterwards mounted the throne, and to have a legislature granted them. The British government, however, was still hesitating whether it should occupy the port, so the emigrants did not trouble themselves about its rights or wishes. Thinking it well to propitiate the Zulu king, Dingaan, whose power overshadowed the country, the Boer leaders proceeded to his kraal to obtain from him a formal grant of land. The grant was made, but next day the treacherous tyrant, offering them some native beer as a sort of stirrup-cup before their departure, suddenly bade his men fall upon and "kill the wizards." The excellent Retief perished with his whole party, and a body of emigrants not far distant was similarly surprised and massacred by a Zulu army of overwhelming strength. These cruelties roused the rest of the emigrants to reprisals, and in 
CHAP.

a fierce battle, fought on December 16,1838 , the anniversary of which is still celebrated by the people of the Transvaal, a handful of Boers overthrew Dingaan's host. Like the soldiers of Cortes in Mexico, they owed this, as other victories, not merely to their steady valour, but to their horses. Riding up to the line of savage warriors, they delivered a volley, and rode back before an assagai could reach them, repeating this manœuvre over and over again till the hostile ranks broke and fled. Ultimately their forces, united with those of a brother of Dingaan, who had rebelled against him and had detached a large part of the Zulu warriors, drove Dingaan out of Zululand in 1840 . Panda, the rebei brother, was installed king in his stead, as a sort of vassal to the Boer government, which was now entitled the republic of Natalia, and the Boers founded a city, Pietermaritzburg, and began to portion out the land. They deemed the British authorities to have abandoned any claim to the country by the withdrawal of a detachment of troops which had been landed at Port Natal in 1838 . But their action, and in particular their ejection from the country of a mass of Kafirs whom they proposed to place in a district already occupied by another tribe, had meanwhile excited the displeasure of the government of Cape Colony. That government, though it had not followed them into the deserts of the interior, had never renounced, and indeed had now and then reasserted, its right to consider them British subjects. They, however, repudiated all 
idea of subjection, holding British sovereignty to be purely territorial, so that when they had passed out of the region which the British crown claimed they had become a free and independent people, standing alone in the world. Their attempt to establish a new white state on the coast was a matter of serious concern, because it might affect trade with the interior, and plant in a region which Britain deemed her own the germ of what might become a new maritime power. And as the colonial government considered itself the general protector of the natives, and interested in maintaining the Kafirs between the Boer state and Cape Colony, the attacks of the Boers on the Kafirs who lived to the west of them toward the Colony, could not be permitted to pass unchecked. The British government, though still unwilling to assume fresh responsibilities, for in those days it was generally believed that the colonial possessions of Britain were already too extensive, nevertheless ultimately concluded, for the reasons given above, to assert its authority over Port Natal and the country behind as far as the crest of the mountains. A small force was accordingly sent to Port Natal in I842. It was there besieged by the Boer levies, and would have been forced to surrender but for the daring ten days' ride through the whole breadth of Kaffraria of a young Englishman, Richard King, who brought the news to Graham's Town, six hundred miles distant. A force sent by sea relieved the starving garrison after a siege of twenty-six days. The Boer forces 
dispersed, but it was not till a year later that the territory of Natal was formally declared a British colony. Lord Stanley, then colonial secretary, was reluctant to take over the responsibilities of a new dominion with a disaffected white population and a mass of savage inhabitants, and only yielded to the urgent arguments of Sir George Napier, then governor of the Cape. In 1843, after long and angry debates (sometimes interrupted by the women, who passionately denounced the British government), the Volksraad, or popular assembly of the tiny republic, submitted to the British crown, having delivered a warm but ineffectual protest against the principle of equal civil rights for whites and blacks laid down by the British government. The colony of Natal was then constituted, first (1845) as a dependency of Cape Colony, afterward (1856) as a separate colony. A part of the Boers, estimated at five hundred families, remained in it, but the majority, including all the fiercer spirits, recrossed the mountains (some forthwith, some five years later), with their cattle, and joined the mass of their fellowemigrants who had remained on the plateaus of the interior. Meanwhile an immense influx of Kafirs, mostly from Zululand, although many belonged to other tribes whom the Zulus had conquered, repopulated the country, and in it the blacks have since been about ten times as numerous as the whites. Thus ended the Dutch republic of Natalia, after six years of troubled life. While it was fighting with the Zulus on the east, and other Kafirs on 
the west, it was torn by incessant intestine quarrels, and unable either to levy taxes, or to compel for any other purpose the obedience of its own citizens. But its victories over Dingaan's armies were feats of arms as remarkable as any South Africa has seen. The English are not generally slow to recognise the fine qualities of their adversaries, but they have done less than justice to the resolution and the daring which the Boers displayed in these early campaigns against the natives. ${ }^{1}$

With the British annexation of Natal ended the first of the attempts which the emigrant Boers have made to obtain access to the sea. It was a turningpoint in the history of South Africa, for it secured to Great Britain that command of the coast which has ever since been seen to be more and more vital to her predominance, and it established a new centre of English settlement in a region till then neglected, from whence large territories, including Zululand and, recently, Southern Tongaland, have been acquired. Although Britain purported to act, and, indeed, in a certain sense did act, in self-defence, one cannot repress a feeling that the Boer settlers, who had occupied a territory they found vacant and had broken the power of the savage Zulu king, were hardly used. They ought, at any rate, to have had earlier notice of British intentions. But against this may be set the fact that the internal dissensions

1 A clear and spirited account of these events may be found in Mr. R. Russell's book, Natal, the Land and its Story, published in 1894 . 
which rent the infant republic would have sooner or later brought it to the ground, compelling British intervention, and that the native races have fared better under British control than they seemed likely to do under that of the Boers, whose behaviour towards them, though little more harsh than that of the English colonists, has been much less considerate than that of the Imperial Government.

Hardly less troubled was the lot of the emigrants who had scattered themselves over the wide uplands that lie between the Orange River and the Limpopo. They, too, were engaged in incessant wars with the native tribes, who were, however, less formidable than the Zulus, and much cattle-lifting went on upon both sides. Only one native tribe and one native chief stand out from the confused tangle of petty raids and forays which makes up (after the expulsion of the Matabili) the earlier annals of the Boer communities. This chief was the famous Moshesh, to speak of whose career I may digress for a moment from the thread of this narrative. The Kafir races have produced within this century three really remarkable men-men who, like Toussaint l'Ouverture in Hayti, and Kamehameha I. in Hawaii, will go down in history as instances of the gifts that sometimes show themselves even among the most backward races. Tshaka, the Zulu, was a warrior of extraordinary energy and ambition, whose power of organization enabled him to raise the Zulu army within a few years to a perfection of drill and dis- 
cipline and a swiftness of movement which made them irresistible, except by Europeans. Khama, the chief who still reigns among the Bechuanas, has been a social reformer and administrator of judgment, tact, and firmness, who has kept his people in domestic peace and protected them from the dangerous influences which white civilization brings with it, while at the same time helping them onward toward such improvements as their character admits. Moshesh, chief of the Basutos, was born in the end of the eighteenth century. He belonged to a small clan which had suffered severely in the wars caused by the conquests of Tshaka, whose attacks upon the tribes nearest him had driven them upon other tribes, and brought slaughter and confusion upon the whole of south-eastern Africa. Though only a younger son, his enterprise and courage soon made him a leader. The progress of his power was aided by the skill he showed in selecting for his residence and stronghold a flat-topped hill called Thaba Bosiyo, fenced round by cliffs, with pasture for his cattle, and several springs of water. In this impregnable stronghold, from which he drew his title of "chief of the mountain," he resisted repeated sieges by his native enemies and by the emigrant Boers. The exploits of Moshesh against his native foes soon brought adherents round him, and he became the head of that powerful tribe, largely formed out of the fragments of other tribes scattered and shattered by war, which is now called the Basuto. Unlike most Kafir warriors, he was singularly free from 
cruelty, and ruled his own people with a mildness which made him liked as well as respected. In I 832 he had the foresight to invite missionaries to come and settle among his people, and the following year saw the establishment of the mission of the Evangelical Society of Paris, whose members, some of them French, some Swiss, some Scotch, have been the most potent factors in the subsequent history of the Basuto nation. When the inevitable collision between the Basutos and the white men arrived, Moshesh, partly through counsels of the missionaries, partly from his own prudence, did his best to avoid any fatal breach with the British Government. Nevertheless, he was several times engaged in war with the Orange River Boers, and once had to withstand the attack of a strong British force led by the governor of Cape Colony. But his tactful diplomacy made him a match for any European opponent, and carried him through every political danger. Moshesh died, full of years and honour, about twenty-five years ago, having built up, out of the dispersed remnants of broken tribes, a nation which has now, under the guiding hand of the missionaries, and latterly of the British Government also, made greater progress in civilization and Christianity than any other Kafir race. Of its present condition I shall speak in a later chapter.

We may now turn back to pursue the story of the fortunes of the emigrant Boers who had remained on the landward or northerly side of the Quathlamba 
Range, or had returned thither from Natal. In I 843 they numbered not more than I 5,000 persons all told, possibly less; for, though after I 838 fresh emigrants from the Colony had joined them, many had perished in the native wars. Subsequently, down to the end of 1847 , these numbers were increased by others, who returned from Natal, displeased at the land settlement made there; and while these Natalians settled, some to the southwest, round Winburg, others farther north, in the region between Pretoria and the Vaal River, the earlier Boer occupants of the latter region moved off still farther north, some to Lydenburg, some to the Zoutpansberg and the country sloping to the Limpopo River. Thus the emigrant Dutch were now scattered over an area seven hundred miles long and three hundred miles wide, an area bounded on the southeast by the Quathlamba mountain-chain, but on the north and west divided by no natural limit from the great plain which stretches west to the Atlantic and north to the Zambesi. They were practically independent, for the colonial government did not attempt to interfere with their internal affairs. But Britain still claimed that they were, in strict intendment of law, British subjects, ${ }^{1}$ and she gave no recognition to the

1 Sir P. Maitland's proclamation of August 21, I845, expressly reserved the rights of the crown to consider those who had gone beyond Natal as being still its subjects, notwithstanding the establishment of a settled government in that Colony. (See Bird's Annals of Natal, vol. ii., p. 468.) 
governments they set up. To have established any kind of administration over so wide a territory would have been in any case difficult for so small a body of people, probably about four thousand adult males; but the characteristics which had enabled them to carry out their exodus from Cape Colony and their campaigns of conquest against the natives with so much success made the task of organization still more difficult. They had in an eminent degree "the defects of their qualities." They were selfreliant and individualistic to excess ; they loved not only independence, but isolation; they were resolved to make their government absolutely popular, and little disposed to brook the control even of the authorities they had themselves created. They had, in fact, a genius for disobedience ; their ideal, if one can attribute any ideals to them, was that of Israel in the days when every man did that which was right in his own eyes. It was only for warlike expeditions, which they had come to enjoy not only for the sake of the excitement, but also because they were able to enrich themselves by the capture of cattle, that they could be brought together, and only to their leaders in war that they would yield obedience. Very few had taken to agriculture, for which, indeed, the dry soil was seldom fitted, and the halfnomadic life of stock-farmers, each pasturing his cattle over great tracts of country, confirmed their dissociative instincts. However, the necessities of defence against the natives, and a common spirit of hostility to the claims of sovereignty which the 
British Government had never renounced, kept them loosely together. Thus several small republican communities grew up. Each would have preferred to manage its affairs by a general meeting of the citizens, and sometimes tried to do so. But as the citizens dispersed themselves over the country, this became impossible, so authority, such slight authority as they could be induced to grant, was in each vested in a small elective assembly called the Volksraad or Council of the People.

These tiny republics were held together by a sort of faintly federative tie, which rested rather in a common understanding than upon any legal instrument, and whose observance was always subject to the passion of the moment. The communities which dwelt to the north-east, beyond the Vaal River, while distracted by internal feuds chiefly arising from personal or family enmities, were left undisturbed by the colonial government. They lived hundreds of miles from the nearest British outpost, and their wars with the Kafirs scarcely affected those tribes with whom the British authorities came in contact. Those authorities, as I have already observed, were in those days, under orders received from home, anxious rather to contract than to extend the sphere of imperial influence, and cared little for what happened far out in the wilderness, except whenever the action of the Boers induced troubles among the natives.

It was otherwise with the emigrants who lived to the south-west, between the Vaal River and the 
frontier of Cape Colony, which was then at the village of Colesberg, between what is now De Aar Junction and the upper course of the Orange River. Here there were endless bickerings between the Boers, the rapidly growing native tribe of the Basutos, and the half-breeds called Griquas, hunting clans sprung from Dutch fathers and Hottentot women, who, intermixed with white people, and to some extent civilized by the missionaries, were scattered over the country from where the town of Kimberley now stands southward to the junction of the Orange and Caledon rivers. These quarrels, with the perpetual risk of a serious native war arising from them, distressed a succession of governors at Cape Town and a succession of colonial secretaries in Downing Street. Britain did not wish (if I may use a commercial term not unsuited to her state of mind) "to increase her holding" in South Africa. She regarded the Cape as the least prosperous and promising of her colonies, with an arid soil, a population largely alien, and an apparently endless series of costly Kafir wars. She desired to avoid all further annexations of territory, because each annexation brought fresh responsibilities, and fresh responsibilities involved increased expenditure. At last a plan was proposed by Dr. Philip, a prominent missionary who had acquired influence with the government. The missionaries were the only responsible persons who knew much about the wild interior, and they were often called on to discharge 
functions similar to those which the bishops performed for the barbarian kings in western Europe in the fifth and sixth centuries of our era. The societies which they represented commanded some influence in Parliament; and this fact also disposed the Colonial Office to consult them. Dr. Philip suggested the creation along the north-eastern border of a line of native states which should sever the Colony from the unsettled districts, and should isolate the more turbulent emigrant Boers from those who had remained quietly in the Colony. This plan was adopted. Treaties were made in I 843 with Moshesh, the Basuto chief, and with Adam Kok, a Griqua captain living on the Orange River, as a treaty had been made nine years before with another Griqua leader named Waterboer, who lived farther north (near the present site of Kimberley); and these three states, all recognized by Britain, were intended to cover the Colony on the side where troubles were most feared. But the arrangement soon broke down, for the whites would not recognize a Griqua captain, while the old troubles between them and the natives continued. Accordingly, a forward step was taken in 1846 by placing a few British troops under a military resident at Bloemfontein, half-way between the Orange and Vaal rivers, to keep order there. And in 1848 the whole region from the Orange to the Vaal was formally annexed under the name of the Orange River Sovereignty. The country had been without any government, for the emigrants who dwelt in it 
had no organization of their own, and did not recognize the republics beyond the Vaal.

This formal assertion of British authority provoked an outbreak among those of the emigrants, all, or nearly all, of Boer stock, who clung to their independence. Roused and reinforced by their Boer brethren from beyond the Vaal, who were commanded by Andries Pretorius, the most energetic and capable of the emigrant leaders, and the same who had besieged the British troops at Port Natal, they attacked Bloemfontein, obliged the Resident's small force to capitulate, and advanced south to the Orange River. Sir Harry Smith, then Governor of the Cape, promptly moved forward a small force, defeated the Boers in a sharp skirmish at Boomplats (August 29, 1848), and re-established British authority over the Sovereignty, which was not, however, incorporated with Cape Colony. The Boers beyond the Vaal were left to themselves.

Peace, however, was not yet assured. Fresh quarrels broke out among the native tribes, ending in a war between the Basutos and the British Resident. Unsupported by a large section of the local farmers, who remained disaffected to the government, and preferred to make their own terms with the Basutos, and having only a trifling armed force at his command, the Resident fared ill; and his position became worse when Pretorius, still powerful beyond the Vaal, threatened to move in and side with the Basutos. Cape Colony was at that moment involved in a serious war with the Kafirs of the 
south coast, and could spare no troops for these northern troubles. So when Pretorius intimated that he and the northern Boers wished to make some permanent pacific arrangement with Britain, which, though it did not claim their territory, still claimed their allegiance, commissioners were sent to negotiate with him and those of the northern or Transvaal group of emigrants who recognized his leadership, for there were other factions who stood apart by themselves. Thus in $185^{2}$ a convention was concluded at Sand River with "the commandant and delegates of the Boers living beyond the Vaal," by which the British government "guaranteed to the emigrant farmers beyond the Vaal River the right to manage their own affairs, and to govern themselves according to their own laws without any interference on the part of the British government," with provisions "disclaiming all alliances with any of the coloured nations north of the Vaal River," permitting the emigrants to purchase ammunition in the British colonies, and declaring that "no slavery is or shall be permitted or practised by the farmers in the country north of the Vaal River."

From this Sand River convention the South African Republic, afterward slowly formed out of the small communities which then divided the country, dates its independence; and by the same instrument it practically severed itself from the Boer emigrants who were left in the Orange River Sovereignty south of the Vaal, conduct which the republican party among these emigrants deemed a 
CH.AP.

betrayal. That Sovereignty remained British, and probably would have so continued but for an unexpected incident. It was still vexed by the war with the Basutos, and when General Cathcart, who had now come out as governor of the Cape, attacked Moshesh with a considerable force of British regulars, he was drawn into a sort of ambush in their difficult country, suffered a serious reverse, and would have been compelled to invade Basutoland afresh with a larger army had not Moshesh prudently asked for peace. Peace was concluded. But the British government was weary of these petty and apparently unending native wars, and soon after the news of the battle with Moshesh reached London, the Duke of Newcastle, and Lord Aberdeen's government, in which he was colonial secretary, resolved to abandon the Sovereignty altogether.

To those who look back on 1853 with the eyes of I 897 this seems a strange determination, for the British crown had ruled the country for eight years and recently given it a regular new constitution. Moreover, whereas the farmers beyond the Vaal were nearly all of pure Boer stock, those in the Orange River Sovereignty were mixed with English settlers, and from their proximity to the Colony were much less averse to the British connection. In fact, a large part of them-though it is not now easy to discover the exact proportion-warmly resisted the proposal of the British government to retire, and independence had to be forced on them 
against their will. In Cape Colony, too, and among the missionaries, there was a strong repugnance to the policy of withdrawal. The authorities of the Colony and the Colonial Office at home were, however, inexorable. They saw no use in keeping territories which were costly because they had to be defended against native raids, and from which little benefit was then expected. Hardly any notice had been taken in Britain of the Sand River convention, which the Conservative ministry of that day had approved, and when, at the instance of delegates sent home by those who, in the Orange River territory, desired to remain subject to the British crown, a motion was made in the House of Commons asking the Queen to reconsider the renunciation of her sovereignty over that territory, the motion found no support and had to be withdrawn. Parliament, indeed, went so far as to vote fortyeight thousand pounds by way of compensation, in order to get rid of this large territory and a great number of attached subjects. So little did Englishmen then care for that South African dominion which they have subsequently become so eager to develop and extend.

By the convention signed at Bloemfontein on February 23, I 854, the British government "guaranteed the future independence of the country and its government," and its inhabitants were "declared, to all intents and purposes, a free and independent people." No slavery or trade in slaves was to be permitted north of the Orange River. The Orange 
River government was to be free to purchase ammunition in the British colonies, and liberal privileges in connection with import duties were to be granted to it.

These two conventions of $185^{2}$ and 1854 are epochs of supreme importance in South African history, for they mark the first establishment of non-British independent states, whose relations with the British colonies were thereafter to constitute the central thread in the annals of the country. As that of 1852 recognized the Transvaal state, so from that of I854, which is a more explicit and complete declaration of independence than had been accorded to the Transvaal people two years before, dates the beginning of the second Boer republic, the Orange Free State, which, subsequently increased by the conquest from the Basutos of a strip of fertile territory in the south, has ever since remained perfectly independent and at peace with the British colonies. Its only serious troubles have arisen from native wars, and these have long ago come to an end. In I 854 an assembly of delegates enacted for it the republican constitution under which it has ever since been quietly and peaceably governed. It had the good fortune to elect as its president, in 1865 , a lawyer from Cape Colony, of Dutch extraction, Mr. (afterwards Sir) John Brand, who guided its course with great tact and wisdom for twenty-four years, and whose favourite expression, "All shall come right," now inscribed on his tombstone at Bloemfontein, has become throughout South Africa 
a proverbial phrase of encouragement in moments of difficulty. ${ }^{1}$

Beyond the Vaal River things have gone very differently. The farmers of that region were more scattered, more rude and uneducated, and more prone to factious dissensions than those of the Free State proved to be after 1854 ; and while the latter were compressed within definite boundaries on three sides, the Transvaal Boers were scattered over a practically limitless area. During the next twentyfive years the Transvaal people had very little to do with the British government. But they were distracted by internal feuds, and involved in almost incessant strife with the natives. These two sources of trouble brought their government, in 1877 , to a condition of virtual collapse. But that collapse and the annexation which followed it belong to a later phase of South African history, and we must now turn from them to trace the progress of events in other parts of the country between 1852 and 1877 .

1 Some further account of the Orange Free State will be found in Chapter XIX. 


\section{CHAPTER XII}

THE EUROPEANS IN SOUTH AFRICA, I 854-95

BETwEen the years $185^{2}$ and 1856 the history of Anglo-Dutch South Africa breaks up into four distinct streams. The Transvaal or South African Republic pursues its own course from I 852 onward, the Orange Free State from I854, and Natal from 1856 , in which year that district was separated from the Cape and constituted as a distinct colony. Between 1876 and I 880 the South African Republic and Natal are again brought into close relations with the march of events in Cape Colony. But before we trace the three last mentioned streams in their several courses it is well to return to the Cape, by far the largest and most populous of the four communities, and sketch in outline the chief events that mark the development of that Colony down to the memorable epoch of $1877-8 \mathrm{I}$.

These events group themselves into three divisions -the material progress of Cape Colony, the changes in the form of its government, and those wars with the Kafir tribes which, while they retarded its growth in population, steadily increased its area. 
The departure of some eight or ten thousand Boers, the most discontented part of the population, in the years following 1835 , not only removed an element which, excellent in other respects, was politically at once unrestful and old-fashioned, but left plenty of vacant space to be occupied by new immigrants from Europe. New immigrants, however, came slowly, because at that time the tide of British emigration set mainly to America, while German emigration had hardly begun. The Kafir wars had, moreover, given South Africa a bad name, and the settlers of 1820 (see above, p. I 36 ) had suffered several years of hardship before prosperity came to them. However, between 1845 and 1850 four or five thousand British immigrants were brought in, with the aid of the government, and a little later a number of Germans who had served England in the German Legion during the Crimean War. Again, in I 858, more than two thousand German peasants were settled on the south coast in lands which had been previously held by Kafirs. These people made good colonists, and have now become merged in the British population, which began to predominate in the eastern province as the Dutch still does in the western. As the country filled there was a steady, though slow, progress in farming and in export trade. The merino sheep had been introduced in 1812 and 1820 , and its wool had now become a source of wealth; so, too, had ostrich farming, which began about 1865 and developed rapidly after the introduction of artificial incubation 
in I869. The finances, which had been in disorder, were set right, roads began to be made, churches and schools were established, and though the Kafir raids caused much loss of life and of cattle on the eastern border, the cost of these native wars, being chiefly borne by the home government, did not burden the colonial revenue. In I859 the first railway was constructed, and by 1883 more than one thousand miles of railway were open for traffic. There were, however, no industries except stockkeeping and tillage until I 869-70, when the discovery of diamonds (of which more anon) brought a sudden rush of immigrants from Europe, stimulated trade so powerfully that the revenue of the Colony doubled within five years, and began that surprising development of mineral resources which has been the most striking feature of recent years.

With the growth of population, which had risen under British rule from about 26,000 Europeans in I 805 to 182,000 in 1865 and 237,000 in 1875 , there came also changes in the form of government. At first the Governor was an autocrat, except so far as he was controlled by the fear that the colonists might appeal to the Colonial Office in London against him: and the administration was therefore wise or foolish, liberal or severe, according to the qualities of the individual Governor. Some serious mistakes were committed, and one Governor, Lord Charles Somerset, has left the reputation of arbitrary rule; but the officials sent out seem, on the whole, to have pursued a more judicious policy and shown 
more respect to local opinion than the representatives of the Dutch East India Company had (with one or two brilliant exceptions) done in the previous century. The blunders which preceded the Great Trek of ${ }_{1} 8_{3} 6$ were attributable rather to the home government than to its agents on the spot, and in the years that followed colonial feeling complained more often of Downing-street than it did of Government House at Cape Town. The irritation which from time to time broke out sprang chiefly from questions connected with the natives. Like all Europeans dwelling among inferior races, the mass of the colonists, English as well as Dutch, looked upon the native population as existing for their benefit, and resented the efforts which the home government made to secure for the blacks equal civil rights and adequate protection. Their wrath was specially kindled by the vehemence with which a few among the missionaries denounced any wrongs deemed to have been suffered by the natives within the Colony, and argued the case of the Kafir tribes who were from time to time in revolt. I do not attempt to apportion the blame in these disputes; but any one who has watched the relations of superior and inferior races in America or India or the Pacific islands will think it probable that many harsh and unjust things were done by the colonists, as every one who knows how zeal tends to mislead the judgment of well-intentioned men will think it no less probable that there was some exaggeration on the part of the philanthropic friends of the blacks, and that some 
CHAP.

groundless charges were brought against the colonists. The missionaries, especially those of the London :Society, had a certain influence with the Colonial Office, and were supposed to have much more than they had. Thus from I 820 to about I 860 there was a perpetual struggle between the colonists and the missionaries, in which struggle the Governor tended to side with the colonists, whose public opinion he felt round him, while the Colonial Office leaned to the philanthropists, who could bring political pressure to bear through the House of Commons. Unfortunate as these bickerings were, they had at least the result of tending to unite the Dutch and English elements in the population, for on native questions there was little difference of attitude between those elements.

In 1834 a Legislative Council was created, consisting, however, of officials and of members nominated by the Governor, and not, as the colonists had petitioned, chosen by election. Twenty years later, when the population had greatly increased and the demand for representative institutions could no longer be resisted, a regular twochambered legislature was set up, consisting of a Legislative Council and a House of Assembly, both elected on a wide franchise, with no distinction of race or colour, though of course the coloured voters were comparatively few, because the tribal Kafirs living under their chiefs were excluded, while of other blacks there was only a small proportion who held property even to the limited extent required 
for the suffrage. This legislature met for the first time in 1854 . Four years previously an event had occurred which showed how desirable it was that constitutional means should be provided for the expression of the people's wishes. The home government had sent out a vessel carrying a number of convicts to be landed and kept in the Colony, where no convicts had been seen since the days of the Dutch Company. A strong and unanimous feeling arose at once against this scheme, which was regarded as likely to prove even more harmful in South Africa than it had proved in Australia, because there was at the Cape a large native population, among whom the escaped or released convict, possessing the knowledge and capacity of a white man, but unrestrained by any responsibility or sense of a character to lose, would be able to work untold mischief. The inhabitants of Cape Town and its neighbourhood held meetings of protest, sent remonstrances to England, and mutually pledged themselves to supply no food to the convict ship. This pledge they carried out, and during the five months that the convict ship lay in Simon's Bay, it was from the naval squadron there that she had to receive provisions. The Colonial Office at last yielded, and the people, while rejoiced at the success they had achieved, and at the heartiness with which Dutch and English had co-operated for a common object, were more than ever disposed to desire some control over their own affairs.

Although after 1854 the sole power of legislation 
was vested in the colonial Parliament, subject to the right of the British crown to disallow an act,-a right which is of course very rarely used,-the executive power still remained with the governor and his council, who were appointed by the home government, and not responsible to the Cape legislature. It has, however, become a settled principle of British colonial policy to grant to each and every colony not only legislative power, but responsible executive government so soon as the white population of the colony has become relatively large enough and settled enough to enable that kind of constitution to be properly worked. In I 872 the whites of Cape Colony had come to exceed 200,000, and the need for a change had been emphasized shortly before by a conflict of opinion between the governor and the legislature as to the best means of setting right the finances of the Colony. Parliament having been dissolved, the new houses declared for responsible government, and the home government wisely assented to their wish. Accordingly, the "cabinet system" of Britain was established, the governor's executive council being turned into a ministry responsible to the legislature, and the governor himself becoming a sort of local constitutional sovereign on the model of the British crown, that is to say, a sovereign who reigns but does not govern, the executive acts done in his name being done by the advice and on the responsibility of the ministry, who hold office at the pleasure of the legislature. Thus from $I S 72$ onward the Colony 
has enjoyed complete self-government, and has prospered under it despite the antagonism which has frequently shown itself between the eastern and western provinces, an antagonism due partly to economic causes, partly to the predominance of the English element in the former and of the Dutch in the latter region. The working of the cabinet system has been even smoother than in most of the other British colonies; but while setting this to the credit of the good sense and moderation of the people, it must also be noted that the most exciting crises which have arisen in South Africa have lain outside the scope of the colonial ministry and legislature, being matters which have touched the two Dutch republics or the relations of British territories to foreign Powers. These matters, being international, belong to the British crown, and to its local representative, the Governor, in his capacity of High Commissioner for South Africa; and in that capacity he is not required to consult the Cape ministry and legislature, but acts under the directions of the Colonial Office in London.

The grant of cabinet government tended to stimulate political life among the Dutch farmers, hitherto the more backward part of the population, and in I 882 their wishes secured a reversal of the ordinance made sixty years before for the exclusive use of English in official documents and legal proceedings. Dutch was now placed on a level with English as an official language in Parliament and the law courts. But this assertion of Dutch sentiment was 
due to causes which will be better understood when we come to the events of 1880 and I88I.

Most of the peaceful growth which has been described would have been more rapid but for the frequent vexation of native wars. Twice under the rule of the Dutch Company and seven times under the British crown have there been sanguinary conflicts with the fierce Kafir tribes of the Kosa group, who dwell to the east of the Colony. On the north there had been only Hottentots, a weak nomad race, who soon vanished under the attacks of smallpox and the pressure of the whites. On the north-east the deserts of the Karroo lay between the colonists and the Kafirs who inhabited the plains of the Upper Orange and Vaal rivers. But on the east the country was comparatively well watered, and supported a large Kafir population full of courage and fighting spirit. Collisions between them and the whites were inevitable. The country they occupied was mostly rugged, and covered with a dense low wood, or rather scrub, traversed by narrow and winding tracks, which were of course familiar to them, and difficult for white troops. They had always the advantage in point of numbers, and though they were usually beaten and compelled to sue for peace, the obvious anxiety of the colonial government to conclude a peace emboldened them to fresh outbreaks. To civilized men, who know the enormous superiority of discipline and of firearms, it seems strange that these natives, who in the earlier wars had no firearms, should have so often 
renewed what we can see was a hopeless struggle. But it must be remembered that the natives, who saw only small white forces brought against them, and knew that the whole number of whites in the Colony was small, have never realized, and do not realize even to-day, the enormous reserve of white population in Europe. Their minds cannot take in large numbers, cannot look far forward, cannot grasp large issues, and are swayed by sudden gusts of feeling which overcome all calculation of results. Accordingly, the Kafirs returned over and over again to the contest, while the colonial government, not wishing to extend its frontiers, and hating the expense of this unprofitable strife, never grappled with the problem in a large way, but tried on each occasion to do just enough to restore order for the time being. It would probably have been better to have spent once for all a large sum in a thorough conquest of the Kosas, planting strong forts here and there through their country, and organizing a regular gendarmerie. But until the annexation of Natal in 1843 placed British power on the other side of these turbulent tribes, the process of conquest might well seem interminable, for it was plain that as soon as one clan had been brought to submission troubles would break out with the next that lay beyond it, and fresh wars have to be undertaken to reduce each of these in its turn. Some allowance must therefore be made for the tendency of the government to take short views and do no more than was needed for the moment, especially as 
CHAP.

nearly every new war brought upon the governor for the time being the displeasure of the Colonial Office, and brought upon the Colonial Office the censure of economists and philanthropists at home.

The theatre of these wars was the country along the south coast between Algoa Bay and the Kei River, and an important step forward was made when, after the wars of $1846-47$ and $185 \mathrm{I}-53$, the province of British Kaffraria, extending to the Kei River, was created, placed under imperial officials, and garrisoned by British regiments. Four years afterwards, in 1857 , the Kafirs of this province, at the bidding of their chiefs, prompted by a wizard who professed to have received messages from the world of spirits, destroyed their cattle and their stores of grain, in the belief that the dead ancestors of the tribe would reappear and join them in driving out the white men, while herds of cattle would issue from the ground and crops would suddenly spring up and cover the soil. Many of the clans were already on the verge of famine when the promised day arrived, and when it had passed starvation began, and within a few months, despite the efforts of the colonial authorities to supply food, some 30,000 Kafirs perished of hunger or disease. This frightful catastrophe, which carried many thousands westward into Cape Colony in search of work, and left large tracts vacant, led to the establishment in those tracts of white settlers, and ultimately, in 1865 , to the union of British Kaffraria with the Colony. It 
also so much weakened the Kosas that for the unprecedentedly long period of twenty years there was no Kafir war. In I 1877 and 1880 some risings occurred which were suppressed with no great difficulty; and in 1894 the boundaries of the Colony, which had been advancing by a series of small annexations, were finally rounded off on the eastern side by the addition of the territory of the Pondos, which made it conterminous in that direction with the colony of Natal.

To complete the chronicle of native wars, we ought now to turn to Natal, on whose borders there arose, in 1879 , a conflict with the greatest native power-that of the Zulus-which the British had yet encountered. Before that year, however, a momentous change in British colonial policy had occurred, and I must go a little way back to describe the events which gave rise to it.

The reader will recollect that in $185^{2}$ and 1854 Britain had abjured all purpose of extending the boundaries of her dominion towards the interior by recognizing the independence of the two Dutch republics, which date their legal rise from the two conventions concluded in those years. She had done so quite honestly, desiring to avoid the expense and responsibility which further advances must entail, and with the wish of leaving the two new republics to work out their own salvation in their own way. For some years nothing occurred to create fresh difficulties. But in $185^{8}$ a war broke out between the Orange Free State and the Basuto chief Moshesh, 
who claimed land which the Free State farmers had occupied. The Free State commandos attacked him, and had penetrated Basutoland as far as the stronghold of Thaba Bosiyo, when they were obliged to return to protect their own farms from the roving bands of horsemen which Moshesh had skilfully detached to operate in their rear. Being hard pressed, they appealed to the Governor of Cape Colony to mediate between them and Moshesh. Moshesh agreed, and a new frontier was settled by the Governor. However, in 1865 fresh troubles broke out, and there was again war between Moshesh and the Free State. The Governor of Cape Colony was again invoked, but his decision was not respected by the Basutos, whom Moshesh could not always control,-for they are much less submissive to their chiefs than are the Zulus,and hostilities having recommenced after a brief interval of peace, the Free State made a supreme effort, and in I868 was on the point of destroying the Basuto power, though it had never been able to capture Thaba Bosiyo, when Moshesh appealed to the High Commissioner to extend British protection to his people. Unwilling to see Basutoland annexed by the Free State, and fearing injury to the Colony from the dispersion of Basuto fugitives through it, the High Commissioner consented, and declared the Basutos British subjects. The Free State was suffered to retain a large tract of fertile land along the north bank of the Caledon River, which it had conquered; but it was mortified by seeing British 
authority established to the south of it, all the way from Natal to the borders of Cape Colony, and by the final extinction of the hopes which it had cherished of extending its territories to the sea and acquiring a harbour at the mouth of the St. John's River.

These events, which befell in I869, mark the recommencement of British advance toward the interior. Still more momentous was another occurrence which belongs to the same year. In 1869 and 1870 a sudden rush began from all parts of South Africa to a small district between the Modder and the Vaal rivers (where the town of Kimberley now stands), in which diamonds had been discovered. Within a few months thousands of diggers from Europe and America, as well as from the surrounding countries, were at work here, and the region, hitherto neglected, became a prize of inestimable value. A question at once arose as to its ownership. The Orange Free State claimed it, but it was also claimed by a Griqua (half-breed) captain, named ${ }^{2}$ Nicholas Waterboer, son of old Andries Waterboer, and by a native ${ }^{3}$ Batlapin chief, as well as by the ${ }^{\dagger}$ Transvaal Republic. The claims of the lastnamed state were disposed of by the decision of the Governor of Natal, who had been recognized as arbitrator by the Griquas, the Batlapin, and the President of the Republic. He awarded the tract in dispute to Waterboer, thereby cutting out the Free State, which had not been a party to the arbitration; and Waterboer placed himself under the 
British government, which presently erected the country into a Crown Colony under the name of Griqualand West. This was in $187 \mathrm{I}$. The Free State protested, and was after a time able to appeal to a judgment delivered by a British court, which found that Waterboer had never enjoyed any right to the territory. However the colony had by this time been set up and the British flag displayed. The British government, without either admitting or denying the Free State title, declared that a district in which it was difficult to keep order amid a turbulent and shifting population ought to be under the control of a strong power, and offered the Free State a sum of ninety thousand pounds in settlement of whatever claim it might possess. The acceptance by the Free State in 1876 of this sum closed the controversy, though a sense of injustice continued to rankle in the breasts of some of the citizens of the Republic. Amicable relations have subsisted ever since between it and Cape Colony, and the control of the British government over the Basutos has secured for it peace in the quarter which was formerly most disturbed.

These two cases show how various are the causes and how mixed the motives which press a great power forward even against the wishes of its statesmen. The Basutos were declared British subjects partly out of a sympathetic wish to rescue and protect them, partly because policy required the acquisition of a country naturally strong and holding an important strategical position. Griqua- 
land West, taken in the belief that Waterboer had a good title to it, was retained after this belief had been dispelled, partly perhaps because a population had crowded into it which consisted mainly of British subjects, and was not easily controllable by a small state, but mainly because colonial feeling refused to part with a region of such exceptional mineral wealth. And the retention of Griqualand West caused, before long, the acquisition of Bechuanaland, which in its turn naturally led to that northward extension of British influence which has carried the Union Jack to the shores of Lake Tanganyika. The wish to restrict responsibility, which had been so strong twenty years before, had now died out of the British public at home, and had grown feebler even in the minds of the statesmen whose business it was to find the money needed for these increasing charges on the imperial treasury; while the philanthropic interest in the native races, stimulated by the discoveries of Livingstone, now took the form not of proposing to leave them to themselves, but of desiring to protect them against the adventurers, whether of Boer or of English blood, whom it was found impossible to prevent from pressing forward into the wilderness.

It is remarkable that the change, as yet only an incipient change, in the public opinion of the English people, who now began to feel the desire not merely to retain but to expand their colonial dominion, should have become apparent just at the time when there 
CHAP.

occurred that discovery of diamonds which showed that this hitherto least progressive of the larger colonies possessed unsuspected stores of wealth. The discovery brought a new stream of enterprising and ambitious men into the country, and fixed the attention of the world upon it. It was a turning point in South African history.

That change in the views of the British Government on which I have been commenting found at this moment a fresh expression in another quarter. In 1869 the Portuguese Government concluded a commercial treaty with the South African Republic, under which it seemed probable that a considerable trade might spring up between the Portuguese coast of the Indian Ocean and the interior. This called attention to the port of Lourenço Marques, on the shore of Delagoa Bay, the best haven upon that coast. Great Britain claimed it under a cession which had been obtained from a native chief of the country by a British naval exploring expedition in I822. Portugal, however, resisted the claim. In I 872 it was referred to the arbitration of Marshal MacMahon, then President of the French Republic, and in 1875 he awarded the territory in dispute to Portugal. Both cases were weak, and it is not easy to say which was the weaker, for, although the Portuguese had undoubtedly been first on the ground, their occupation, often disturbed by the native tribes, had been extremely precarious. The decision was a serious blow to British hopes, and has become increasingly serious with the further development of 
the country. Yet it was mitigated by a provision contained in the agreement for arbitration, that the Power against whom the decision might go should have thereafter from the successful Power a right of preëmption as against any other state desiring to purchase the territory. ${ }^{1}$ This provision is momentous as giving Britain the right to prevent not only the South African Republic, but any European power, from acquiring a point of the utmost importance both commercial and strategical. Rumours have often been circulated that Britain would gladly acquire by purchase the harbour of Delagoa Bay, but the sensitive patriotism of the Portuguese people is at present so strongly opposed to any sale of territory that no Portuguese ministry is likely to propose it. ${ }^{2}$

At the very time when the attempt to acquire Delagoa Bay revealed the new purposes which had begun to animate Great Britain, another scheme was suggested to the Colonial Office by the success which had lately attended its efforts in Canada. In I 867 the passing of the British North America Act drew the theretofore isolated provinces of the Dominion into a confederation, relieving the home government of some grave responsibilities, and giving to the whole country the advantages of

1 It has been stated (see Mr. Molteno's Federal South Africa, p. 87) that Portugal was then prepared to sell her rights for a small sum-according to report, for $£$ I 2,000 .

${ }^{2}$ In 189 I the southern boundary of Portuguese territory was fixed by a treaty with Great Britain at a point on the coast named Kosi Bay, about seventy miles south of Lourenço Marques. 
CH.AP.

common administration and legislation in matters of common concern. Lord Carnarvon, then colonial secretary, threw himself into the idea of similarly uniting the different colonies and states of South Africa. It had been advocated by Sir George Grey, when Governor in 1858 , and had even received the support of the Orange Free State, whose Volksraad passed a resolution favouring it in that year. Many considerations of practical convenience suggested this scheme, chief among them the desirability of having both a uniform policy in native affairs (the absence of which had recently caused trouble) and a common commercial policy and tariff system. Accordingly, in I 875 Lord Carnarvon addressed a despatch to the Governor of Cape Colony, recommending such a scheme as fit to be adopted by that colony, which three years before had received responsible government, and Mr. J. A. Froude was sent out to press it upon the people. The choice did not prove a fortunate one, but even a more skilful emissary would probably have failed, for the moment was inopportune. The Cape people were not ready for so large and far-reaching a proposal. The Orange Free State was exasperated at the loss of Griqualand West. The Transvaal people, though, as we shall see presently, their republic was in sore straits, were averse to anything that could affect their independence. However, Sir Bartle Frere, the next Governor of the Cape, who went out in 1877 , entered heartily into Lord Carnarvon's plan, which continued to be pressed till I880, when it was 
rejected by the Cape Parliament, largely at the instance of envoys from the Transvaal Boers, who urged the Cape Boers not to accept it until the Transvaal (which, as shall be presently set forth, had been annexed in 1877 ) should have regained its independence. This failure of the proposals of the home government seriously damaged the prospects of future federation schemes, and is only one of several instances in South African history that show how much harm impatience may do, even when the object is itself laudable.

The next step in the forward march of British rule took place far to the south-west, on the borders of Natal. That territory had, in 1856 , become a separate colony, distinct from the Cape, and with a legislative council three-fourths of whose members were elective. It had still a relatively small white population, for many of the Boer immigrants had quitted it between 1843 and I848, and though a body of English settlers arrived soon after the latter year, there were in 1878 only some 25,000 white residents, while the natives numbered fully 300,000 . The Zulu kingdom, which adjoined it on the east, had passed (in 1872) from the sluggish Panda to his more energetic son Cetewayo (pronounced "Ketshwayo"), whose ambitious spirit had revived the military organization and traditions of his uncle Tshaka. Cetewayo had been installed as king by a British official, and had lived ever since at peace with the colony; but the powerful army which he possessed roused disquiet among the Natalians, and 
alarmed the then Governor of the Cape and High Commissioner for South Africa, Sir Bartle Frere. Differences had arisen between him and Cetewayo, and when the latter refused to submit to the demands which the High Commissioner addressed to him, including a requirement that he should disband his regiments and receive a British resident, war was declared against him. This act was justified at the time on the ground that the Zulu military power constituted a standing menace to Natal and to South Africa in general, and that the vast majority of the natives living in Natal itself might join the Zulu king were he to invade the colony. Whether this risk was sufficiently imminent to warrant such a step was then, and has been since, warmly debated in England. Most of those who have given impartial study to the subject, and have studied also the character and earlier career of the High Commissioner, are disposed to think that war might have been and ought to have been avoided, and that Sir Bartle Frere, in declaring it, committed a grave error; but it is right to add that there are persons in South Africa who still defend his action. The invasion of Zululand which followed began with a disaster-the surprise at Isandhlwana (January, I879) of a British force, which was almost annihilated by a vastly superior native army. Ultimately, however, Cetewayo was defeated and made prisoner. Zululand was divided among thirteen petty chiefs under a British resident, and subsequently, in 1887 , annexed to the 
British crown as a dependency, to be administered by the Governor of Natal. Except for some disturbances in 1888 , its people have since remained peaceful, prosperous, and to all appearance contented. It has now (I897) been decided to annex Zululand to Natal.

We may now return to follow the fortunes of the emigrant Boers of the far north-eastern interior, whose republic, recognized by the Imperial Government in I 852, was at length, after twenty-five years, to be brought into a closer connection than ever with the British colonies by events which are still fresh in men's memories, and which are exerting a potent influence on the politics of our own time. The scale of these events was small, but the circumstances are full of instruction, and many years may yet elapse before their consequences have been fully worked out.

The Dutch farmers who had settled beyond the Vaal River were more rude and uneducated than those of the Free State, had no admixture of English blood, and remained unaffected by intercourse with the more civilized people of Cape Colony. Their love of independence was accompanied by a tendency to discord. Their warlike spirit had produced a readiness to take up arms on slight occasions, and had degenerated into a fondness for predatory expeditions. They were, moreover, always desirous of enlarging the area of their stock farms by the annexation of fresh territory to the north and west, and thus were 
CHAP.

constantly brought into collision with the native occupants of the country. Scattered over a wide area of pasture-land, they were practically exempt from the control of law-courts or magistrates, while at the same time the smallness of their numbers, and the family ties which linked them into jealous and mutually distrustful groups, gave rise to personal rivalries among the leaders and bitter feuds among the adherents of each faction, resembling those which used to distract a city republic in ancient Greece or medieval Italy. The absence of any effective government had attracted many adventurers from various parts of South Africa, who wandered as traders or hunters through the wilder parts of the country and along its borders, men often violent and reckless, who ill-treated the natives. and constituted not only a public scandal, but, by the provocations which they gave to the Kafir chiefs, a danger to the peace of the adjoining British territories, as well as to that of the Transvaal itself.

From their first settlement beyond the Vaal in the years immediately following the Great Trek of 1836 , the farmers, though considering themselves to form one people, had been grouped in several small communities. In $185_{2}$ there were four such, those of Potchefstroom, Utrecht, Lydenburg, and Zoutpansberg, each having its Volksraad (people's council) and president or executive head, while a sort of loosely federative tie linked them together for the purposes, not of internal administration, but of defence against common foes. 
In 1857 the Potchefstroom people tried to conquer the Orange Free State, then in the third year of its life, but desisted on finding that the infant Republic was prepared to defend itself. A single Volksraad for all the communities beyond the Vaal had been chosen as far back as I849; but respect for its authority grew very slowly, and for a time it could not be said to represent more than a party. In 1852 , however, it ratified the Sand River Convention, and in 1855 it appointed a commission to draft a complete body of law. Finally, in 1858 , an instrument called the "Grondwet," or Fundamental Law, was drawn up by a body of delegates named (by a "Krygsraad," or War Council) for that purpose. This instrument was revised and adopted by the Volksraad, and presently received the adhesion of two of the semi-independent communities, those of Potchefstroom and Zoutpansberg, and in 1860 also of those at Lydenburg and Utrecht, which had by that time united. It has been since several times modified, and the question whether it is to be deemed a truly Rigid constitution, like that of the United States or that of the Swiss Confederation, has given rise to much controversy. ${ }^{1}$ A civil war broke out in 1862 , and the country can hardly be said to have reached one united government till

1 See especially the case of Brown vs. Leyds, recently (January, 1897) decided by the High Court of the South African Republic. An English translation of the Grondwet has been published by Mr. W. A. Macfadyen of Pretoria, in a little volume entitled The Political Lazes of the South African Republic. 
I 864, when the then president, Mr. M. W. Pretorius (son of the old antagonist of the English), was recognized by all the communities and factions as their executive head.

Even in 1864 the white population of the South African Republic was very small, probably not more than 30,000 all told, giving an average of less than one person to three square miles. There were, however, hundreds of thousands of natives, a few of whom were living as servants, under a system of enforced labour which was sometimes hardly distinguishable from slavery, while the vast majority were ruled by their own chiefs, some as tributaries of the Republic, some practically independent of it. With the latter wars were frequently raging-wars in which shocking cruelties were perpetrated on both sides, the Kafirs massacring the white families whom they surprised, the Boer commandos taking a savage vengeance upon the tribes when they captured a kraal or mountain stronghold. It was the sight of these wars which drove Dr. Livingstone to begin his famous explorations to the north. The farmers were too few to reduce the natives to submission, though always able to defeat them in the field, and while they relished an expedition, they had an invincible dislike to any protracted operations which cost money. Taxes they would not pay. They lived in a sort of rude plenty among their sheep and cattle, but they had hardly any coined money, conducting their transactions by barter, and they were too rude to value the benefits 
which government secures to a civilized people. Accordingly the treasury remained almost empty, the paper money which was issued fell till in 1870 it was worth only one-fourth of its face value, no public improvements were made, no proper administration existed, and every man did what was right in his own eyes. In $1872 \mathrm{Mr}$. M. W. Pretorius was obliged to resign the presidency, owing to the unpopularity he had incurred by accepting the arbitration mentioned above (p. I 79), which declared the piece of territory where diamonds had been found not to belong to the Republic, and which the Volksraad thereupon repudiated. His successor was $\mathrm{Mr}$. Burgers, a Cape Dutchman who had formerly been a clergyman of the Dutch Reformed Church and afterwards an advocate at the Cape, a man of energy, integrity, and eloquence, but deficient in practical judgment, and who soon became distrusted on account of his theological opinions. It used to be jestingly said that the Boers disliked him because he denied that the devil possessed that tail which is shown in the pictures that adorn the old Dutch Bibles; but his deviations from orthodoxy went much further than this, and were deemed by the people to be the cause of the misfortunes they experienced under his guidance. He formed large plans for the development of the country and the extension of Boer power over South Africa, plans which his citizens were unable to appreciate and the resources at his disposal were quite unfit to accomplish. Disorganization, aggravated by intestine faction, grew worse and worse. The state was practically bank- 
CHAP.

rupt ; trade had ceased, money could not be raised. In 1876, in a war which had broken out with Sikukuni, a Kafir chief who lived in the mountains of the north-east, the Boers were repulsed, and ultimately returned in confusion to their homes. On the south, Cetewayo, then in the zenith of his power, was unfriendly, and seemed likely to pour in his Zulu hordes. The weakness and disorders of the Republic had become a danger not only to the British subjects who had begun to settle in it, especially at the Lydenburg gold mines, but also to the neighbouring British territories, and especially to Natal; so a British commissioner was sent to examine into the condition of the country, with secret instructions empowering him to proclaim, if he should deem it necessary, and if he was satisfied that the majority of the inhabitants would approve, its annexation to the British crown. After three months' inquiry the commissioner, Sir Theophilus Shepstone, exercised this power upon April I2, I 877 , and his act was approved by the High Commissioner at the Cape and by the Colonial Secretary in England. President Burgers had endeavoured to rouse his people by pointing out that only through reforms could they preserve their independence. They agreed to the reforms, but would not help him to carry them out, and obstinately refused to pay taxes. He was helpless, for while the more rigidly Calvinistic section of the population supported Paul Kruger, his opponent in the approaching presidential election, others (especially the English who had settled in the spots where a 
little gold had been found) favoured annexation to Great Britain, and most of the Boers had been repelled by his unorthodox opinions. Accordingly, after entering a protest against the annexation, he returned to Cape Colony, and received a pension, his private means having been entirely spent in the service of his country. ${ }^{1}$ The Vice-President (Mr. Kruger) and the executive council of the Republic also protested, and sent delegates to London to remonstrate. By the mass of the Boer people-for the few English, of course, approved-little displeasure was shown and no resistance made. Had a popular vote been taken it would doubtless have been adverse to annexation, for a memorial circulated shortly afterwards, praying for a reversal of Sir $T$. Shepstone's act, received the signatures of a large majority of the Boer citizens. ${ }^{2}$ But while they regretted their independence, they had been so much depressed by their disasters, and were so much relieved to know that the strong arm of Britain would now repel any Kafir invasion, as to take the change more quietly than any one who remembered their earlier history would have expected.

On the English public, which knew little and cared less about South African affairs, the news that

1 Some extracts from the narrative, vindicating his conduct, which he had prepared and which was published after his death (in I882), may be found in Mr. John Nixon's Complete Story of the Transvaal, an interesting book, though written in no judicial spirit.

2 Although there is some reason to think that if Sir T. Shepstone had waited a few weeks or months, the Boers would have been driven by their difficulties to ask to be annexed. 
CHAP.

their empire had been extended by a territory nearly as large as the United Kingdom, though it came as a complete surprise, produced little impression. They were then excited over the outbreak of the war between Russia and the Turks, and absorbed in the keen party struggles which Lord Beaconsfield's apparent desire to help the Turks had caused in England, so that scant attention was given to a distant colonial question. A motion condemning the annexation which was brought forward in the House of Commons received no support. Nearly all of those few persons who cared about South Africa had been alienated from the Boers by their treatment of the natives. Scarcely any one foresaw the long series of troubles, not yet ended, to which the annexation was destined to give rise. Neither did it arouse any serious opposition in Cape Colony, though the Dutch element there regarded with misgivings the withdrawal of independence from their emigrant kinsfolk.

To those who now look back at the act, in the light of the events that followed, it seems a highhanded proceeding to extinguish a republic which had been formally recognised twenty-five years before, and to do this without giving the people an opportunity of declaring their wishes. Yet the act was not done in a spirit of rapacity. Neither the British government nor the British people had the least idea of the wealth that lay hidden beneath the barren and desolate ridges of the Witwatersrand. No one in England talked (though the notion had 
crossed a few ambitious minds) of pushing British dominion up to the Zambesi. The Transvaal Republic was bankrupt and helpless, distracted by internal quarrels, unable to collect any taxes, apparently unable to defend itself against its Kafir enemies, and likely to be the cause of native troubles which might probably spread till they affected all Europeans in South Africa. There was some reason to believe that the citizens, though they had not been consulted, would soon acquiesce in the change, especially when they found, as they soon did find, that the value of property rose with the prospect of security and of the carrying out of internal improvements by a strong and wealthy power. Such was certainly the belief of Sir T. Shepstone and of Lord Carnarvon, and it seemed to be confirmed by the apparent tranquillity which the Boers exhibited.

So, indeed, they might have acquiesced, notwithstanding their strenuous love of independence, had they been wisely dealt with. But the British government proceeded forthwith to commit three capital blunders.

The first of these, and the least excusable, was the failure to grant that local autonomy which Sir T. Shepstone had announced when he proclaimed annexation. The Volksraad which the people were promised was never convoked; the constitution under which they were to enjoy self-government was never promulgated. There was no intention to break these promises, but merely a delay, culpable, indeed, but due to ignorance of the popular Boer 
CHAP.

sentiment, and to the desire of the Colonial Office to carry out its pet scheme of South African confederation before conceding to the Transvaal such a representative assembly as would have had the power to reject, on behalf of the people, the scheme when tendered to them. Nor were matters mended when at last a legislature was granted, to consist of some officials, and of six members nominated by the governor, for this made the people fear that a genuine freely elected Volksraad would never be conceded at all.

The second blunder was the selection of the person who was to administer the country. Sir T. Shepstone, who knew it well and was liked by the Boers, was replaced by a military officer who had shown vigour in dealing with local disturbances in Griqualand West, but was totally unfit for delicate political work. As representative government had not yet been introduced, his administration was necessarily autocratic in form, and became autocratic in spirit also. He was described to me by some who knew him as stiff in mind and arrogant in temper, incapable of making allowances for the homely manners of the Boers and of adapting himself to the social equality which prevailed among them. A trifling cause aggravated their dislike. His complexion was swarthy, and they suspected that this might be due to some tinge of negro blood. $\mathrm{He}$ refused to listen to their complaints, levied taxes strictly, causing even the beloved ox-waggon to be seized when money was not forthcoming, and soon 
turned their smouldering discontent into active disaffection.

Finally the British government removed the two native dangers which the Boers had feared. An expedition under Sir Garnet Wolseley reduced Sikukuni's strongholds and established peace in the north-east. In 1879, Sir Bartle Frere's war with Cetewayo destroyed the Zulu power, the dread of which might have induced the Boers to resign themselves to British supremacy. It was probably necessary to deal with Sikukuni, though the British government seems to have forgotten its former doubts as to the right of the Boers to the territory of that chief; but in extinguishing the Zulu kingdom the High Commissioner overlooked the fact that he was also extinguishing the strongest motive which the republicans had for remaining British subjects. The British government were doubly unfortunate. It was the annexation of the Transvaal in 1877 that had alarmed Cetewayo and helped to precipitate the war of 1879 . It was now the overthrow of Cetewayo, their formidable enerny, tnat helped to precipitate a revolt of the Boers.

At this time, however, everybody in British South Africa, and nearly everybody in England, supposed the annexation to be irrevocable. Leading members of the parliamentary Opposition had condemned it. But when that Opposition, victorious in the general election of 1880 , took office in April of that year, the officials in South Africa, whose guidance they sought, made light of Boer discontent, and 
CHAP.

declared that it would be impossible now to undo what had been done in 1877 . Thus misled, the new cabinet refused to reverse the annexation, saying by the mouth of the Under-Secretary for the Colonies, "Fieri non debuit, factum valet." This decision of the British government, which came as a surprise upon the recalcitrant republicans in the Transvaal, precipitated an outbreak. In December, I880, a mass-meeting of the Boers was held at a place called Paardekraal (now Krugersdorp). It was resolved to rise in arms; and a triumvirate was elected, consisting of Messrs. M. W. Pretorius, Kruger and Joubert, which proclaimed the re-establishment of the South African Republic, and hoisted the national flag on Dingaan's day, December 16. ${ }^{1}$ The Boers, nearly every man of whom was accustomed to fighting, now rose en masse and attacked the small detachments of British troops scattered through the country, some of which were cut off, while the rest were obliged to retire to posts which they fortified. The Governor of Natal, General Sir George Colley, raised what troops he could in that colony, and marched northward; but before he could reach the Transvaal border a strong force of Boers, commanded by Commandant-General Joubert, crossed it and took up a position at Laing's Nek, a steep ridge marking the watershed between the upper waters of the Klip River, a tributary of the Vaal, and those of the Buffalo River, which joins the Tugela and flows into the Indian Ocean. Here

1 See above, p. 85. 
the British general, on January 28, I88I, attacked the Boers, but was repulsed with heavy loss, for the ridge behind which they were posted protected them from his artillery, while their accurate rifle fire cut down his column as it mounted the slope. A second engagement eleven days later on the Ingogo heights caused severe loss to the British troops. Finally, on the night of February 26, General Colley, with a small detachment, seized by night Majuba Hill, a mountain which rises about I,500 feet above Laing's Nek, and completely commands that pass. ${ }^{1}$ Unfortunately he omitted to direct the main force, which he had left behind at his camp, four miles south of the Nek, to advance against the Boers and occupy their attention; so the latter, finding no movement made against them in front, and receiving no artillery fire from Majuba Hill above them, checked the first impulse to retire, which the sight of British troops on the hilltop had produced, and sent out a volunteer party to scale the hill. Protected by the steep declivities from the fire of the soldiers above them, they made their way up, shooting down those whom they saw against the sky-line, and finally routed the British force, killing General Colley, with ninety-one others, and taking fifty-nine prisoners. By this time fresh troops were beginning to arrive in Natal, and before long the British general who had succeeded to the command had at his disposal a force which the Boers could not possibly have resisted. The home

${ }^{1}$ A description of Majuba Hill will be found in Chapter XVIII. 
CHAP.

government, however, had ordered an armistice to be concluded (March 5), and on March 23 terms were agreed to by which the "Transvaal State" (as it was called) was again recognized as a quasi-independent political community, to enjoy complete self-government under the suzerainty of the British crown. These terms were developed in a more formal convention, signed at Pretoria in August, I $88 \mathrm{I}$, which recognized the Transvaal as autonomous, subject, however, to the suzerainty of the Queen, to British control in matters of foreign policy, to the obligation to allow British troops to pass through the Republic in time of war, and to guarantees for the protection of the natives. The position in which the Transvaal thus found itself placed was a peculiar one, and something between that of a self-governing colony and an absolutely independent state. The nearest legal parallel is to be found in the position of some of the great feudatories of the British crown in India, but the actual circumstances were of course too unlike those of India to make the parallel instructive.

Few public acts of our time have been the subjects of more prolonged and acrimonious controversy than this reversal in $188 \mathrm{I}$ of the annexation of 1877 . The British government were at the time accused, both by the English element in the South African colonies, and by their political opponents at home, of an ignominious surrender. They had, so it was urged, given way to rebellion. They had allowed three defeats to remain unavenged. They had 
weakly yielded to force what they had repeatedly and solemnly refused to peaceful petitions. They had disregarded the pledges given both to Englishmen and to natives in the Transvaal. They had done all this for a race of men who had been uniformly harsh and unjust to the Kafirs, who had brought their own Republic to bankruptcy and chaos by misgovernment, who were and would remain foes of the British empire, who were incapable of appreciating magnanimity, and would construe forbearance as cowardice. They had destroyed the prestige of British power in Africa among whites and blacks, and thereby sowed for themselves or their successors a crop of future difficulties.

To these arguments it was replied that the annexation had been made, and the earlier refusals to reverse it pronounced, under a complete misapprehension as to the facts. The representatives of the Colonial Office in South Africa had reported, partly through insufficient knowledge, partly because their views were influenced by their feelings, that there was no such passion for independence among the Boers as events had shown to exist. ${ }^{1}$ Once the true facts were known, did it not become not merely unjust to deprive the Transvaal people of the freedom they prized so highly, but also impolitic to retain by force those who would have been disaffected

1 Sir B. Frere reported after meeting the leaders of the discontented Boers in April, 1879, that the agitation, though more serious than he supposed, was largely "sentimental," and that the quieter people were being coerced by the more violent into opposition. 
CHAP.

and troublesome subjects? A free nation which professes to be everywhere the friend of freedom is bound-so it was argued-to recognize the principles it maintains even when they work against itself ; and if these considerations went to show that the retrocession of the Transvaal was a proper course, was it either wise or humane to prolong the war and crush the Boer resistance at the cost of much slaughter, merely in order to avenge defeats and vindicate a military superiority which the immensely greater forces of Britain made self-evident? A great country is strong enough to be magnanimous, and shows her greatness better by justice and lenity than by a sanguinary revenge. These moral arguments, which affect different minds differently, were reinforced by a strong ground of policy. The Boers of the Orange Free State had sympathized warmly with their kinsfolk in the Transvaal, and were with difficulty kept from crossing the border to join them. The president of the Free State, a sagacious man, anxious to secure peace, had made himself prominent as a mediator, but it was not certain that his citizens might not, even against his advice, join in the fighting. Among the Africander Dutch of Cape Colony and Natal the feeling for the Transvaal Boers was hardly less strong, and the accentuation of Dutch sentiment, caused by the events of 1880 and $188 \mathrm{I}$, has ever since been a main factor in the politics of Cape Colony. The British government were advised from the Cape that the invasion of the Transvaal might probably light up a civil war 
through the two colonies. The power of Great Britain would of course have prevailed, even against the whole Dutch-speaking population of South Africa ; but it would have prevailed only after much bloodshed, and at the cost of an intense embitterment of feeling, which would have destroyed the prospects of the peace and welfare of the two colonies for many years to come. The loss of the Transvaal seemed a slight evil in comparison.

Whether such a race conflict would in fact have broken out all over South Africa is a question on which opinion is still divided, and about which men may dispute for ever. The British government, however, deemed the risk of it a real one, and by that view their action was mainly governed. After careful inquiries from those best qualified to judge, I am inclined to think that they were right. It must, however, be admitted that the event belied some of their hopes. They had expected that the Transvaal people would appreciate the generosity of the retrocession, as well as the humanity which was willing to forego vengeance for the tarnished lustre of British arms. The Boers, however, saw neither generosity nor humanity in their conduct, but only fear. Jubilant over their victories, and (like the Kafirs in the south coast wars) not realizing the overwhelming force which could have been brought against them, they fancied themselves entitled to add some measure of contempt to the dislike they already cherished to the English, and they have ever since shown themselves unpleasant neighbours. The English in 
CHAP.

South Africa, on their part, have continued to resent the concession of independence to the Transvaal, and especially the method in which it was conceded. Those who had recently settled in the Republic, relying on the declarations repeatedly made that it would for ever remain British, complained that no proper compensation was made to them, and that they had much to suffer from the Boers. Those who live in the two colonies hold that the disgrace (as they term it) of Majuba Hill ought to have been wiped out by a march to Pretoria, and that the Boers should have been made to recognize that Britain is, and will remain, the paramount power in fact as well as in name. They feel aggrieved to this day that the terms of peace were settled at Laing's Nek, within the territory of Natal, while it was still held by the Boers. Even in Cape Colony, where the feeling is perhaps less strong than it is in Natal, the average Englishman has neither forgotten nor forgiven the events of I88I.

I have dwelt fully upon these events because they are, next to the Great Trek of 1836 , the most important in the internal history of South Africa, and those which have most materially affected the present political situation. The few years that followed may be more briefly dismissed. The Transvaal State emerged from its war of independence penniless and unorganized, but with a redoubled sense of divine favour and a reinvigorated consciousness of national life. The old constitution was set to work; the Volksraad again met; Mr. 
Stephen John Paul Kruger, who had been the leading figure in the triumvirate, was chosen by the people to be president, and has subsequently been thrice re-elected to that office. Undismayed by the scantiness of his state resources, he formed bold and far-reaching plans of advance on the three sides which lay open to him. To the north a trek was projected, and some years later was nearly carried out, for the occupation of Mashonaland. To the south bands of Boer adventurers entered Zululand, the first of them as trekkers, the rest as auxiliaries to one of the native chiefs, who were at war with one another. These adventurers established a sort of republic in the northern districts, and would probably have seized the whole had not the British government at last interfered and confined them to a territory of nearly three thousand square miles, which was recognized in 1886 under the name of the New Republic, and which in I888 merged itself in the Transvaal. To the west, other bands of Boer raiders entered Bechuanaland, seized land or obtained grants of land by the usual devices, required the chiefs to acknowledge their supremacy, and proceeded to establish two petty republics, one called Stellaland, round the village of Vryburg, north of Kimberley, and the other, farther north, called Goshen. These violent proceedings, which were not only injurious to the natives, but were obviously part of a plan to add Bechuanaland to the Transvaal territories, and close against the English the path to those northern regions in which Britain 
was already interested, roused the British government. In the end of 1884 an expedition led by Sir Charles Warren entered Bechuanaland. The freebooters of the two republics retired before it, and the districts they had occupied were erected into a Crown Colony under the name of British Bechuanaland. In 1895 this territory was annexed to Cape Colony. In order to prevent the Boers from playing the same game in the country still farther north, where their aggressions had so far back as 1876 led Khama, chief of the Bamangwato, to ask for British protection, a British protectorate was proclaimed (March, I885) over the whole country as far as the borders of Matabililand; and a few years later, in I 888, a treaty was concluded with Lo Bengula, the Matabili king, whereby he undertook not to cede territory to, or make a treaty with, any foreign power without the consent of the British High Commissioner. The west was thus secured against the further advance of the Boers, while on the eastern shore the hoisting of the British flag at St. Lucia Bay in 1884 (a spot already ceded by Panda in I843), followed by the conclusion (in 1887 ) of a treaty with the Tonga chiefs, by which they undertook not to make any treaty with any other power, announced the resolution of the British crown to hold the coast line up to the Portuguese territories.

This policy of preventing the extension of Boer dominion over the natives was, however, accompanied by a willingness to oblige the Transvaal people in other ways. Though they had not 
observed the conditions of the convention of $\mathrm{I} 88 \mathrm{I}$, the Boers had continued to importune the British government for an ampler measure of independence. In 1884 they succeeded in inducing Lord Derby, then Colonial Secretary, to agree to a new convention. It is the basis of the present relations between the British crown and the South African Republic, a title now at last formally conceded. By this instrument (called the Convention of London), whose articles were substituted for the articles of the convention of $\mathrm{I} 88 \mathrm{I}$, the control of foreign policy stipulated for in the Pretoria Convention of I88I was cut down to a provision that the Republic should " conclude no treaty with any state or nation other than the Orange Free State, nor with any native tribe to the eastward or westward of the Republic," without the approval of the Queen. The declarations of the two previous conventions (of $185^{2}$ and I88I) against slavery were repeated, and there was a "most favoured nation" clause with provisions for the good treatment of strangers entering the Republic. Nothing was said as to the "suzerainty of Her Majesty" mentioned in the convention of $\mathrm{I} 88 \mathrm{I}$. The Boers have contended that this omission is equivalent to a renunciation, but to this it has been (among other things) replied that as that suzerainty was recognized not in the "articles" of the instrument of $\mathrm{I} 88 \mathrm{I}$, but in its introductory paragraph, it has not been renounced, and still subsists.

A few years later, the amity which this convention 
was meant to secure was endangered by the plan formed by a body of Boer farmers and adventurers to carry out an idea previously formed by $\mathrm{Mr}$. Kruger, and trek northward into the country beyond the Limpopo River, a country where the natives were feeble and disunited, raided on one side by the Matabili and on the other by Gungunhana. This trek would have brought the emigrants into collision with the English settlers who had shortly before entered Mashonaland. President Kruger, however, being pressed by the imperial government, undertook to check the movement, and so far succeeded that the waggons which crossed the Limpopo were but few and were easily turned back. Prevented from expanding to the north, the Boers were all the more eager to acquire Swaziland, a small but rich territory which lies to the east of their Republic, and is inhabited by a warlike $\mathrm{Kafir}$ race, numbering about 70,000, near of kin to the Zulus, but for many years hostile to them. Both the Boers and Cetewayo had formerly claimed supremacy over this region. The British government had never admitted the Boer claim, but when the head chief of the Swazis had, by a series of improvident concessions, granted away to adventurers, most of them Boers, nearly all the best land and minerals the country contained, it was found extremely difficult to continue the system of joint administration by the High Commissioner and the Transvaal government which had been provisionally established, and all the more difficult because by the concession to the New Republic 
(which had by this time become incorporated with the Transvaal) of the part of Zululand which adjoined Swaziland, direct communication between Natal and Swaziland had become difficult, especially in the malarious season. Accordingly, after long negotiations, an arrangement was concluded, in 1894, which placed the Swazi nation and territory under the control of the South African Republic, subject to full guarantees for the protection of the natives. A previous convention (of 1890 ) had given the South African Republic certain rights of making a railway to the coast at Kosi Bay through the low and malarious region which lies between Swaziland and the sea, and the earlier negotiations had proceeded on the assumption that these rights were to be adjusted and renewed in the same instrument which was destined to settle the Swaziland question. The Boer government, however, ultimately declined to include such an adjustment in the new convention, and as this new convention superseded and extinguished the former one of 1890 , those provisions for access to the sea necessarily lapsed. The British government promptly availed itself of the freedom its rivals had thus tendered to it, and with the consent of the three chiefs (of Tonga race) who rule in the region referred to, proclaimed a protectorate over the strip of land which lies between Swaziland and the sea, as far north as the frontiers of Portuguese territory. Thus the door has been finally closed on the schemes which the Boers have so often sought to carry out for the acquisition of a 
railway communication with the coast entirely under their own control. It was an object unfavourable to the interests of the paramount power, for it would not only have disturbed the commercial relations of the interior with the British coast ports, but would also have favoured the wish of the Boer government to establish political ties with other European powers. The accomplishment of that design was no doubt subjected by the London convention of I 884 to the veto of Britain. But in diplomacy facts as well as treaties have their force, and a Power which has a seaport, and can fly a flag on the ocean, is in a very different position from one cut off by intervening territories from those whose support it is supposed to seek. Thus the establishment of the protectorate over these petty Tonga chiefs may be justly deemed one of the most important events in recent South African history.

Down to I884 Great Britain and Portugal had been the only European powers established in South Africa. For some time before that year there had been German mission stations in parts of the region which lies between the Orange River and the West African possessions of Portugal, and in $188_{3}$ a Bremen merchant named Lüderitz established a trading-factory at the bay of Angra Pequeña, which lies on the Atlantic coast about one hundred and fifty miles north of the mouth of that river, and obtained from a neighbouring chief a cession of a piece of territory there, which the German government a few months later recognized as a German 
colony. Five years earlier, in 1878 , Walfish Bay, which lies farther north, and is the best haven (or rather roadstead) on the coast, had been annexed to Cape Colony; but though it was generally understood both in the Colony and in England, that the whole of the west coast up to the Portuguese boundary was in some vague way subject to British influence, nothing had been done to claim any distinct right, much less to perfect that right by occupation. The Colony had always declined or omitted to vote money for the purpose, and the home government had not cared to spend any. When the colonists knew that Germany was really establishing herself as their neighbour on the north, they were much annoyed; but it was now too late to resist, and in I 884, after a long correspondence, not creditable to the foresight or promptitude of the late Lord Derby, who was then Colonial Secretary, the protectorate of Germany was formally recognised, while in 1890 the boundaries of the German and British "spheres of influence" farther north were defined by a formal agreement-the same agreement which settled the respective "spheres of influence" of the two powers in eastern Africa, between the Zambesi and the Upper Nile. Although the people of Cape Colony continue to express their regret at having a great European power conterminous with them on the north, there has been really little or no practical contact between the Germans and the colonists, for while the northern part of the Colony, lying along the lower course of the Orange River, is so arid as to be very 
thinly peopled, the southern part of the German territory, called Great Namaqualand, is a wilderness inhabited only by wandering Hottentots (though parts of it are good pasture land), while, to the west, Namaqualand is separated from the habitable parts of British Bechuanaland by the great Kalahari Desert.

The new impulse for colonial expansion which had prompted the Germans to occupy Damaraland and the Cameroons on the western, and the Zanzibar coasts on the eastern, side of Africa was now telling on other European powers, and made them all join in the scramble for Africa, a continent which a few years before had been deemed worthless. Italy and France entered the field in the north-east, France in the north-west, and Britain, which had in earlier days moved with such slow and wavering steps in the far south, was roused by the competition to a swifter advance. Within nine years from the assumption of the protectorate over British Bechuanaland, which the action of the Boers had brought about in 1885 , the whole unappropriated country up to the Zambesi, came under British control.

In 1888 a treaty made with Lo Bengula extended the range of British influence and claim not only over Matabililand proper, but over Mashonaland and an undefined territory to the eastward whereof Lo Bengula claimed to be suzerain. Next came, in I889, the grant of a royal charter to a company, known as the British South Africa Company, which had been formed to develop this eastern side of Lo Bengula's dominion, and to work the 
gold mines believed to exist there, an undertaking chiefly due to the bold and forceful spirit of Mr. Cecil Rhodes, who perceived that if Britain did not speedily establish some right to the country, the Transvaal Boers would trek in and acquire it. In I 890 the pioneer British settlers moved up through Bechuanaland into Mashonaland, and the Company, which, like the East India Company of the eighteenth century, was to be a ruling and administering power as well as a trading association, established itself along the eastern part of the great plateau and began to build forts. Here it came into collision with the Portuguese, who, stimulated by the activity of other nations, had been reasserting their dormant claims to the interior and sending up expeditions to occupy the country. A skirmish which occurred near Massikessi, in Manicaland, ended in the repulse of the Portuguese and the capture of their commanders, who were, however, soon after released by Dr. Jameson, the newly appointed administrator of the Company ; and another conflict in May, I89I, in which the Portuguese again suffered severely, hastened the conclusion of a treaty (June, I89I) between Great Britain and Portugal, by which the boundary between the Portuguese territories and those included in the British "sphere of influence" was fixed. By this treaty a vast region in the interior which lies along the Upper Zambesi west of Portuguese territory and south of the Congo Free State was recognized by Portugal as within the British sphere. An 
agreement of the preceding year between Germany and Great Britain (July I, I 890) had defined the limits of German and British influence on the east side of the continent; and as Germany, Portugal, and the Congo State were the only civilized powers conterminous with Great Britain in this part of the world, these treaties, together with the instrument - to which Great Britain had been a party-that determined the limits of the Congo State, settled finally all these questions of the interior, and gave to Great Britain a legal title to her share of it.

That title, however, like the other titles by which the European powers held their new African possessions, was a paper title, and valid only as against other neighbouring European powers. It had nothing whatever to do with the Kafir tribes who dwelt in the country. What are called the rights of a civilized Power as against the natives rest in some cases upon treaties made with the chiefs, treaties of whose effect the chiefs are often ignorant ; and in others on the mere will of the European Power which proclaims to the world that it claims the country; and it is held that the Power which makes the claim must, at least in the latter class of cases, perfect its claim by actual occupation. In the case of these new British territories treaties were made with a certain number of chiefs. One already existed with Lo Bengula, king of the Matabili; but it merely bound him not to league himself with any other power, and did not make him a British vassal. It was clear, however, that 
with so restless and warlike a race as the Matabili this state of things could not last long. Lo Bengula had been annoyed at the march of the pioneers into Mashonaland, and tried to stop them, but was foiled by the swiftness of their movements. Once they were established there he seems to have desired to keep the peace; but his young warriors would not suffer him to do so. They had been accustomed to go raiding among the feeble and disunited Mashonas, whom they slaughtered and plundered to their hearts' content. When they found that the Company resented these attacks, collisions occurred, and the reluctance to fight which Lo Bengula probably felt counted for little. What he could do he did: he protected with scrupulous care not only the missionaries, but other Europeans at his kraal, and, after the war had broken out, he sent envoys to treat, two of whom, by a deplorable error, were killed by the advancing column of Bechuanaland imperial police, for as the Company's officers were not at the moment prepared, either in money or in men, for a conflict, the Imperial Government sent a force northward from Bechuanaland to co-operate with that which the Company had in Mashonaland. A raid by Matabili warriors on the Mashonas living near Fort Victoria, whom they called their slaves, precipitated hostilities (July to October, 1893). The Matabili, whose vain confidence in their own prowess led them to attack in the open when they ought to have resorted to bush fighting, were defeated in two battles by the 
CHAP.

Company's men. Lo Bengula fled towards the Zambesi and died there (January, 1894) of fever and despair, as Shere Ali Khan had died when chased out of Kabul by the British in 1878 ; while his indunas and the bulk of the Matabili people submitted with little further resistance. Matabililand was now occupied by the Company, which shortly afterwards took possession of the northern part of its sphere of operations by running a telegraph wire across the Zambesi and by placing officers on the shore of Lake Tanganyika. In March, I 896, the Matabili and some of the Mashona chiefs revolted, but after five months' fighting, in which many lives were lost, peace was restored, and the rapid progress of two railways into the heart of the country of these tribes gives a great, if not complete, security against a renewal of like troubles. ${ }^{1}$

By the establishment of the British South Africa Company to the north of the Transvaal that state had now become inclosed in British territory on every side except the east; nor could it advance to Delagoa Bay, because Portugal was bound by the Arbitration Treaty of 1872 to allow Great Britain a right of pre-emption over her territory there. Meantime new forces had begun to work within the Republic. Between 1867 and 1872 gold had been found in several places on the eastern side of the country, but in quantities so small that no one attached much importance to the discovery. After I882, however, it began to be pretty largely worked.

1 See further as to this rising some remarks in Chapter XV. 
In 1885 the conglomerate or banket beds of the Witwatersrand were discovered, ${ }^{1}$ and the influx of strangers, which had been considerable from 1882 onward, increased immensely, till in 1895 the number of recent immigrants, most of whom were adult males, had risen to a number (roughly estimated at I00,000) largely exceeding that of the whole Boer population. Although the first result of the working of the gold mines and the growth of the towns had been to swell the revenues of the previously impecunious Republic, President Kruger and the Boers generally were alarmed at seeing a tide of aliens from the colonies and Europe and the United States, most of them British subjects, and nearly all speaking English, rise up around and threaten to submerge them. They proceeded to defend themselves by restricting the electoral franchise, which had theretofore been easily acquirable by immigrants. Laws were passed which, by excluding the newcomers, kept the native Boer element in a safe majority; and even when in 1890 a concession was made by the creation of a second legislative chamber, based on a more extended franchise, its powers were carefully restricted, and the election not only of the First Raad (the principal chamber), but also of the president and executive council, remained confined to those who had full citizenship under the previous statutes. Discontent spread among the new-comers, who complained both of their exclusion from political rights and of various

${ }^{1}$ See Chapter XVIII. for an account of these beds. 
grievances which they and the mining industry suffered at the hands of the government. A reform association was formed in I892. In 1894 the visit of the British High Commissioner, who had come from the Cape to negotiate with the President on Swaziland and other pending questions, led to a vehement pro-British and anti-Boer demonstration at Pretoria, and thenceforward feeling ran high at Johannesburg, the new centre of the Rand mining district and of the immigrant population. Finally, in December, I895, a rising took place at Johannesburg, the circumstances attending which must be set forth in the briefest way, for the uncontroverted facts are fresh in every one's recollection, while an attempt to discuss the controverted ones would lead me from the field of history into that of contemporary politics. ${ }^{1}$ It is enough to say while a large section of the Uitlanders (as the new alien immigrants are called) in Johannesburg were preparing to press their claims for reforms upon the government, and to provide themselves with arms for that purpose, an outbreak was precipitated by the entry into Transvaal territory from Pitsani in Bechuanaland of a force of about five hundred men, mostly in the service of the British South Africa Company as police, and led by the Company's Ad-

1 The salient facts may be found in the evidence taken by the committee of inquiry appointed by the Cape Assembly in 1896 . The much more copious evidence taken by a Select Committee of the British House of Commons in 1897 adds comparatively little of importance to what the Cape committee had ascertained. 
ministrator, with whom (and with Mr. Rhodes, the managing director of the Company) a prior arrangement had been made by the reform leaders, that in case of trouble at Johannesburg he should, if summoned, come to the aid of the Uitlander movement. A question as to the flag under which the movement was to be made caused a postponement of the day previously fixed for making it. The leaders of the force at Pitsani, however, became impatient, thinking that the Boer government was beginning to suspect their intentions; and thus, though requested to remain quiet, the force started on the evening of December 29. Had they been able, as they expected to get through without fighting, they might probably have reached Johannesburg in three or four days' march, for the distance is only I 70 miles. But while the High Commissioner issued a proclamation disavowing their action and ordering them to retire, they found themselves opposed by the now rapidly gathering Boer levies, were repulsed at Krugersdorp, and ultimately forced to surrender on the forenoon of January I, I896, at a place called Doornkop. The Johannesburg Uitlanders, who, though unprepared for any such sudden movement, had risen in sympathy at the news of the inroad, laid down their arms a few days later. ${ }^{1}$

1 Of the many accounts of the incidents that led to this rising which have appeared, the clearest and one of the fairest I have met with is contained in the book of M. Mermeix, La Revolution de Johannesburg. A simple and graphic sketch has been given by an American lady (Mrs. J. H. Hammond), in her little book entitled $A$ Woman's Part in a Revolution. 
I have given the bare outline of these latest events in South African history for the sake of bringing the narrative down to the date when I began to write. But as I was at Pretoria and Johannesburg immediately before the rising of December 1895 took place, and had good opportunities of seeing what forces were at work, and in what direction the currents of opinion were setting, I propose to give in a subsequent chapter (Chapter XXV) a somewhat fuller description of the state of things in the Transvaal at the end of 1895 , and to reserve for a still later chapter some general reflections on the course of South African history. 
PART III

A JOURNEY THROUGH SOUTH

AFRICA 



\section{CHAPTER XIII}

TRAVELLING AND COMMUNICATIONS

THERE is nothing one more desires to know about a country, and especially a new country, than how one can travel through it. There was nothirg about which, when contemplating a journey to South Africa, I found it more difficult to get proper information in England; so I hope that a few facts and hints will be useful to those who mean to make the tour, while to others they may serve to give a notion of the conditions which help or obstruct internal communication.

First, as to coast travel. There is no line of railway running along the coast, partly because the towns are small, as well as few and far between, partly because the physical difficulties of constructing a railway across the ridges which run down to the sea are considerable, but chiefly, no doubt, because the coasting-steamers are able to do what is needed. The large vessels of the Castle Line and the Union Line run once a week between Cape Town and Durban (the port of Natal), calling at Port Elizabeth and East London, sometimes also at Mossel Bay. Thus one 
can find two opportunities every week of getting east or west in powerful ocean steamers, besides such chances as smaller vessels, designed for freight rather than for passengers, supply. From Durban there is one weekly boat as far as Delagoa Bay, a voyage of about twenty-four hours. From Delagoa Bay northward to Beira and Mozambique the traveller must rely either on the steamers of the German East Africa Line, which run from Hamburg through the Red Sea all the way to Durban, making the entire voyage in about seven weeks, or on Messrs. Rennie's line, which ply from Durban to Delagoa Bay, Beira and Chinde. The drawback to these coast voyages is that the sea is apt to be rough between Cape Town and Durban, less frequently so between Durban and Beira, and that there is no sheltered port between Cape Town and Delagoa Bay. At Port Elizabeth and at East London the large steamers lie out in the ocean, and passengers reach the land by a small tender, into which they are let down in a sort of basket, if there is a sea running, and are occasionally, if the sea be very high, obliged to wait for a day or more until the tender can take them off. Similar conditions have prevailed at Durban, where a bar has hitherto prevented the big liners, except under very favourable conditions of tide and weather, from entering the otherwise excellent port. Much, however, has recently been done to remove the Durban bar, and it is expected that the largest steamers will soon be able to cross it at high tide. At Delagoa Bay the harbour is spacious and sheltered, though the 
approach requires care and is not well buoyed and lighted. At Beira the haven is still better, and can be entered at all states of the tide. There is now a brisk goods trade, both along the coast between the ports I have mentioned, and from Europe to each of them.

Secondly, as to the railways. The railway system is a simple one. A great trunk-line runs north-eastward from Cape Town to a place called De Aar Junction, in the eastern part of the Colony. Here it bifurcates. One branch runs first east and then north-north-east through the Orange Free State and the Transvaal to Pretoria; the other runs north by east to Kimberley and Mafeking, and is now being continued through Bechuanaland to Bulawayo. The distance from Cape Town to Pretoria is ten hundred and forty miles, and the journey takes (by the fastest train) fifty-two hours. From Cape Town to Mafeking it is eight hundred and seventy-five miles, the journey taking about fifty hours. From this trunk-line two important branches run southward to the coast, one to Port Elizabeth, the other to East London; and by these branches the goods landed at those ports, and destined for Kimberley or Johannesburg, are sent up. The passenger traffic on the branches is small, as people who want to go from the Eastern towns to Cape Town usually take the less fatiguing as well as cheaper sea voyage.

Three other lines of railway remain. One, opened in the end of 1895, connects Durban with Pretoria and Johannesburg; another, opened in 1894, runs 
CHAP.

from Delagoa Bay to Pretoria; a third, opened part of it in 1894 and the rest in 1896 , connects Beira with a place called Chimoyo in the Portuguese dominions, and is being now built therefrom to Mtali and Fort Salisbury, in the territory of the British South Africa Company. ${ }^{1}$

Of these railways the trunk-line with its branches was constructed by and is (except the parts which traverse the Orange Free State and the Transvaal) owned by the government of Cape Colony. It has latterly paid very well. The line from Durban to the Transvaal border at Charlestown belongs to the Natal government, and is also a considerable source of revenue. The rest of this line, from Charlestown northward through the Transvaal, is the property of a Dutch company, which also owns the line from Delagoa Bay to Pretoria and from Pretoria to the frontier of the Free State. The Beira railway belongs to a company controlled by the British South Africa Company, and is virtually a part of that great undertaking.

All these railways, except the Beira line, have the same gauge, one of three feet six inches. The Beira line has a two-foot gauge, but will probably be enlarged as the traffic increases. Throughout South Africa the lines of railway are laid on steeper gradients than is usual in Europe: one in forty is not uncommon, and on the Natal line it is some-

1 There is also a line of railway from Port Elizabeth to GraafReinet, some short branch lines near Cape Torn, and a small line from Graham's Town to the coast at Port Alfred. 
times one in thirty, though this is being gradually reduced. Although the accommodation at the minor stations is extremely simple, and sometimes even primitive, the railways are well managed, and the cars are arranged with a view to sleep on the night journeys; so that one can manage even the long transit from Cape Town to Pretoria with no great fatigue. Considering how very thinly peopled the country is, so that there is practically no local passenger and very little local goods traffic, the railway service is much better than could have been expected, and does great credit to the enterprise of the people.

Railways have made an enormous difference, not to travel only, but to trade and to politics; for before the construction of the great trunk-line (which was not opened to Pretoria till 1892) the only means of conveyance was the ox-waggon. The ox-waggon needs a few words of description, for it is the most characteristic feature of South African travel. It is a long, low structure, drawn by seven, eight, nine, or even ten yoke of oxen, and is surmounted (when intended to carry travellers) by a convex wooden frame and canvas roof. The animals are harnessed by a strong and heavy chain attached to the yoke which holds each pair together. The oxen usually accomplish about twelve miles a day, but can be made to do sixteen, or with pressure a little more. They walk very slowly, and they are allowed to rest and feed more hours than those during which they travel. The rest-time is usually 
the forenoon and till about four P.M., with another rest for part of the night. It was in these waggons that the Boers carried with them their wives and children and household goods in the great exodus of I 836 . It was in such waggons that nearly all the explorations of South Africa have been made, such as those by the missionaries, and particularly by Robert Moffat and by Livingstone (in his earlier journeys), and such as those of the hunting pioneers, men like Anderson, Gordon-Cumming, and Selous. And to this day it is on the waggon that whoever traverses any unfrequented region must rely. Horses, and even mules, soon break down; and as the traveller must carry his food and other necessaries of camp life with him, he always needs the waggon as a basis of operations, even if he has a seasoned horse which he can use for two or three days when speed is required. Waggons have, moreover, another value for a large party: they can be readily formed into a laager, or camp, by being drawn into a circle, with the oxen placed inside and so kept safe from the attacks of wild beasts. And where there are hostile Kafirs to be feared, such a laager is an efficient fortress, from within which a few determined marksmen have often successfully resisted the onslaught of hordes of natives. To this day an immense trade is carried on by means of oxwaggons between the points where the railways end -Mafeking, Pretoria, and Chimoyo-and the new settlements in Matabililand and Mashonaland. When I passed from Mafeking to Bulawayo in 
October, I895, thousands of oxen were drawing hundreds of waggons along the track between those towns. When, a month later, I travelled from Fort Salisbury to Chimoyo, I passed countless waggons standing idle along the track, because, owing to the locusts and the drought, which had destroyed most of the grass, the oxen had either died or grown too lean and feeble to be able to drag the loads. Hence the cattle-plague which in 1896 carried off the larger part of the transport-oxen has been a terrible misfortune, not only to the natives who owned these animals, but also to the whole northern region, which depends upon cattle transport for its food, its comforts, its building materials, and its mine machinery.

It is the character of the country that has permitted the waggon to become so important a factor in South African exploration, politics, and commerce. The interior, though high, is not generally rugged. Much of it-indeed, all the eastern and northern parts-is a vast rolling plain, across which wheeled vehicles can pass with no greater difficulty than the beds of the streams, sometimes deeply cut through soft ground, present. The ranges of hills which occur here and there are generally traversed by passes, which, though stony, are not steep enough to be impracticable. Over most of the southern half of the plateau there is no wood, and where forests occur the trees seldom grow thick together, and the brushwood is so dry and small that it can soon be cut away to make a passage. 
Had South Africa been thickly wooded, like the eastern parts of North America or some parts of Australia, waggon-travelling would have been difficult or impossible; but most of it is, like the country between the Missouri River and the Great Salt Lake, a dry open country, where the waggon can be made a true ship of the desert. This explains the fact, so surprising to most European readers of African travel and adventure, that wherever man can walk or ride he can take his moving home with him.

For rapid transit, however, the traveller who has passed beyond the railway is now not wholly dependent on the ox. Coaches, drawn sometimes by mules, sometimes by horses, run from many points on the railways to outlying settlements; they are, however, always uncomfortable and not always safe. They travel night and day, usually accomplishing from six to eight miles an hour on good ground, but much less where the surface is sandy or rugged. Coach services are maintained from Mafeking (and also from Pretoria) to Bulawayo, and cover the distance (five hundred miles) in five and a half days and five nights. They are drawn by mules, which are changed every eight or ten miles. Considering the difficulties of the route and the heavy mortality among the animals, this service does the utmost credit to the enterprising Transvaal Dutchman (Mr. Zeederberg) who directs it. In the north and north-east of Cape Colony and in the Transvaal, as well as in Matabililand, horses are very little used either for riding or for driving, owing 
to the prevalence of a disease called horse-sickness, which attacks nearly every animal, and from which only about a quarter recover. This is one reason why so'little exploration has been done on horseback ; and it is a point to be noted by those who desire to travel in the country, and who naturally think of the mode by which people used to make journeys in Europe, and by which they make journeys still in large parts of South and of North America, as well as in western Asia.

I have spoken of the "tracks" used by waggons and coaches; the reader must not suppose that these tracks are roads. There are no made roads in South Africa, except in the neighbourhood of Cape Town, Durban, Maritzburg, Graham's Town, and one or two other towns. Neither are there (except as aforesaid) any bridges, save here and there rude ones of logs thrown across a stream bed. Elsewhere the track is merely a line across the veldt (prairie), marked and sometimes cut deep by the wheels of many waggons, where all that man has done has been to remove the trees or bushes. Here and there the edges of the steep stream banks have been cut down so as to allow a vehicle to descend more easily to the bottom, where during the rains the stream flows, and during the rest of the year the ground is sandy or muddy. After heavy rain a stream is sometimes impassable for days together, and the waggons have to wait on the bank till the torrent subsides. At all times these water channels are troublesome, for the oxen 
CHAP.

or mules are apt to jib or get out of hand in descending the steep slope, and it is no easy matter to get them urged up the steep slope on the other side. Accidents often occur, and altogether it may be said that the dongas-this is the name given to these hollow stream channels-form the most exciting feature of South African travel (in places where wild beasts and natives are no longer dangerous) and afford the greatest scope for the skill of the South African driver.

Skilful he must be, for he never drives less than six span of oxen, and seldom less than three pairs of horses or mules (the Bulawayo coach has five pairs). It takes two men to drive. One wields an immensely long whip, while the other holds the reins. Both incessantly apostrophise the animals. It is chiefly with the whip that the team is driven; but if the team is one of mules, one of the two drivers is for a large part of the time on his feet, running alongside the beasts, beating them with a short whip and shouting to them by their names, with such adjectives, expletives, and other objurgations as he can command. Many Dutchmen do drive wonderfully well.

I have said nothing of internal water travel by river or lake, because none exists. There are no lakes, and there is not a river with water enough to float the smallest steamboat, except some reaches of the Limpopo River in the wet season. The only steamer that plies anywhere on a river is that which ascends the Pungwe River from Beira 
to Fontesvilla; it goes only as far as the tide goes, and on most of its trips spends fully half its time sticking on the sand-banks with which the Pungwe abounds. So far as I know, no one has ever proposed to make a canal in any part of the country.

From what has been said it will be gathered that there is no country where railways are and will be more needed than South Africa. Unfortunately, they will for a great while have no local traffic, because most of the country they pass through has not one white inhabitant to the square mile. Their function is to connect the coast with the distant mining centres, in which population has begun to grow. To lay them is, however, comparatively cheap work. Except in the immediate neighbourhood of a town, nothing has to be paid for the land. The gradients all through the interior plateau are comparatively easy, and the engineers have in Africa cared less for making their ascents gentle than we do in older countries. Even in the hilly parts of the Transvaal and Matabililand the ranges are not high or steep, and one can turn a kopje instead of cutting or tunnelling through it. Few bridges are needed, because there are few rivers. Nevertheless, it will be a great feat for the British South Africa Company to complete their new line from Mafeking to Bulawayo, a distance of fully six hundred miles, in twenty months from the time they set to work at it (March, I896). Their other line, from 
Chimoyo to Fort Salisbury, a shorter one, but through a much more hilly and difficult country, is to be finished and open for traffic in about two years from the time when it was begun. Railways are the chief need of these newest countries, and the best means, next to a wise and conciliatory administration, of preventing fresh native outbreaks.

A word as to another point on which any one planning a tour to South Africa may be curious -the accommodation obtainable. Most travellers have given the inns a bad name. My own experience is scanty, for we were so often the recipient of private hospitality as to have occasion to sleep in an inn (apart from the "stores" of Bechuanaland and Mashonaland, of which more hereafter) in four places only, Mafeking, Ladybrand, Durban, and Bloemfontein. But it seemed to us that, considering the newness of the country and the difficulty in many places of furnishing a house well and of securing provisions, the entertainment was quite tolerable, sometimes much better than one had expected. In the two colonies, and the chief places of the two republics, clean beds and enough to eat can always be had; in the largest places there is nothing to complain of, though the prices are sometimes high. Luxuries are unprocurable, but no sensible man will go to a new country expecting luxuries. 


\section{CHAPTER XIV}

FROM CAPE TOWN TO BULAWAYO

In this and the four following chapters I propose to give some account of the country through which the traveller passes on his way from the coast to the points which are the natural goals of a South African journey, Kimberley and Johannesburg, Bulawayo and Fort Salisbury, hoping thereby to convey a more lively impression of the aspects of the land and its inhabitants than general descriptions can give, and incidentally to find opportunities for touching upon some of the questions on which the future of the country will turn.

First, a few words about the voyage. You can go to South Africa either by one of the great British lines across the Atlantic to the ports of Cape Colony and Natal, or by the German line through the Red Sea and along the East African coast to Beira or Delagoa Bay. The steamers of the German line take thirty days from Port Said to Beira, and two days more to Delagoa Bay. They are good boats, though much smaller than those of the two chief English lines to the Cape (the Castle and the Union), and the voyage from 
Port Said has the advantage of being, at most times of the year, a smooth one pretty nearly the whole way. They touch at Aden, Zanzibar, Dar-es-Salaam, and Quilimane, and give an opportunity of seeing these places. But all along the East African coast the heat is excessive-a damp, depressing heat. And the whole time required to reach Beira from England, even if one travels by rail from Calais to Marseilles, Brindisi, or Naples, and takes a British steamer thence to Port Said, joining the German boat at the latter port, is more than five weeks. Nearly everybody, therefore, chooses the Atlantic route from Southampton or London to the Cape. The Atlantic voyage, which lasts from sixteen to twenty days, is, on the whole, a pleasant and healthful one. The steamers, both those of the Castle Line and those of the Union Line-and the same may be said for the New Zealand Line and the Aberdeen Line which plies to Australia, both of these touching at the Cape-are comfortable and well appointed, and I cannot imagine any navigation more scrupulously careful than that which I saw on board the Hawarden Castle by which I went out and returned. During the winter and spring months there is often pretty rough weather from England as far as Madeira. But from that island onward, or at any rate from the Canaries onward, one has usually a fairly smooth sea with moderate breezes till within two or three days of Cape Town, when head winds are frequently encountered. Nor is the heat excessive. Except during the two days between Cape Verde and 
the equator, it is never more than what one can enjoy during the day and tolerate during the night. One sees land only at Madeira, where the steamer coals for a few hours; at the picturesque Canary Islands, between which she passes, gaining, if the weather be clear, a superb view of the magnificent Peak of Teneriffe; and at Cape Verde, where she runs (in the daytime) within a few miles of the African coast. Those who enjoy the colours of the sea and of the sea skies, and to whom the absence of letters, telegrams, and newspapers is welcome, will find few more agreeable ways of passing a fortnight. After Cape Finistierra very few vessels are seen. After Madeira every night reveals new stars rising from the ocean as our own begin to vanish.

Tutte le stelle già dell' altro polo

Vedea la notte, e il nostro tanto basso

Che non sorgeva fuor del marin suolo, ${ }^{1}$

as Ulysses says, in Dante's poem, of his voyage to the southern hemisphere. The pleasure of watching unfamiliar constellations rise from the east and sweep across the sky, is a keen one, which often kept us late from sleep.

For a few hours only before reaching Cape Town does one discern on the eastern horizon the stern grey mountains that rise along the barren coast. A nobler site for a city and a naval stronghold than that of the capital of South Africa can hardly be imagined. It rivals Gibraltar and

1 "Already night saw all the stars of the other pole, and ours brought so low that it rose not from the surface of the sea." 
CHAP.

Constantinople, Bombay and San Francisco. Immediately behind the town, which lies along the sea, the majestic mass of Table Mountain rises to a height of 3,600 feet, a steep and partly wooded slope capped by a long line of sheer sandstone precipices more than $\mathrm{I}, 000$ feet high, and flanked to right and left by bold, isolated peaks. The beautiful sweep of the bay in front, the towering crags behind, and the romantic pinnacles which rise on either side, make a landscape that no one who has seen it can forget. The town itself is disappointing. It has preserved very little of its old Dutch character. The miniature canals which once traversed it are gone. The streets, except two, are rather narrow, and bordered by low houses; nor is there much to admire in the buildings, except the handsome Parliament House, the new post-office, and the offices of the Standard Bank. The immediate suburbs, inhabited chiefly by Malays and other coloured people, are mean. But the neighbourhood is extremely attractive. To the northwest Table Mountain and its spurs descend steeply to the sea, and the road which runs along the beach past the village of Sea Point offers a long series of striking views of shore and crag. It is on the east, however, that the most beautiful spots lie. Five miles from Cape Town, and connected with it by railway, the village of Rondebosch nestles under the angle of Table Mountain, and a mile farther along the line is the little town of Wynberg. Round these places, or between them and Cape Town, nearly all the richer, and a great many even 
of the poorer, white people of Cape Town live. The roads are bordered by pretty villas, whose grounds, concealed by no walls, are filled with magnolias and other flowering trees and shrubs. Avenues of tall pines or of superb oaks, planted by the Dutch in the last century, run here and there along the by-roads. Immediately above, the grey precipices of Table Mountain tower into the air, while in the opposite direction a break in the woods shows in the far distance the sharp summits, snowtipped during the winter months, of the lofty range of the Hottentots Holland Mountains. It would be hard to find anywhere, even in Italy or the Pyrenees, more exquisite combinations of soft and cultivated landscape with grand mountain forms than this part of the Cape peninsula presents. Perhaps the most charming nook of all is where the quaint old Dutch farmhouse of Groot Constantia ${ }^{1}$ stands among its vineyards, about ten miles from Cape Town. Behind it is the range which connects the hills of Simon's Bay with Table Mountain; its declivities are at this point covered with the graceful silver-tree, whose glistening foliage shines brighter than that of the European olive. Beneath the farm-house are the vineyards which produce the famous sweet wine that bears the name of Constantia, sloping gently toward the waters of False Bay, whose farther side is guarded by a wall of frowning peaks, while the deep blue misty ocean opens in the distance. It is a landscape unlike

${ }^{1}$ Called after Constance, wife of Governor Adrian van der Stel. 
CHAP.

anything one can see in Europe, and though the light in sea and sky is brilliant, the brilliance is on this coast soft and mellow, unlike the clear, sharp radiance of the arid interior.

No one who cares for natural scenery quits Cape Town without ascending Table Mountain, whose summit affords not only a very beautiful and extensive prospect over the surrounding country, but a very striking ocean view. Looking down the narrow gullies that descend from the top, one sees the intensely blue sea closing them below, framed between their jutting crags, while on the other side the busy streets and wharves of Cape Town lie directly under the eye, and one can discover the vehicles in the streets and the trees in the Governor's garden. The heaths and other flowers and shrubs that grow profusely over the wide top, which is not flat, as he who looks at it from the sea fancies, but cut up by glens, with here and there lake reservoirs in the hollows, are very lovely, and give a novel and peculiar charm to this ascent. ${ }^{1}$ Nor is the excursion to Cape Point, the real Cape of Storms of Bartholomew Diaz, and the Cape of Good Hope of Vasco da Gama, less beautiful. An hour in the railway brings one to Simon's Bay, the station of the British naval squadron, a small but fairly well

1 Nimble climbers will do well to descend from the top down a grand cleft in the rocks, very narrow and extremely steep, which is called the Great Kloof. At its bottom, just behind Cape Town, one sees in a stream-bed the granite rock on which the horizontal strata of sandstone that form Table Mountain rest. 
sheltered inlet under high hills. From this one drives for four hours over a very rough track through a lonely and silent country, sometimes sandy, sometimes thick with brushwood, but everywhere decked with brilliant flowers, to the Cape, a magnificent headland rising almost vertically from the ocean to a height of 800 feet. Long, heavy surges are always foaming on the rocks below, and nowhere, even on this troubled coast, where the hot Mozambique current meets a stream of cold Antarctic water, do gales more often howl and shriek than round these rocky pinnacles. One can well understand the terror with which the Portuguese sailors five centuries ago used to see the grim headland loom up through the clouds driven by the strong southeasters, that kept them struggling for days or weeks to round the cape that marked their way to India. But Sir Francis Drake, who passed it coming home westward from his ever-famous voyage round the world, had a more auspicious experience : "We ran hard aboard the Cape, finding the report of the Portuguese to be most false, who affirm that it is the most dangerous cape of the world, never without intolerable storms and present danger to travellers who come near the same. This cape is a most stately thing, and the finest cape we saw in the whole circumference of the earth."

A third excursion, which well repays the traveller, is to the quaint little town of Stellenbosch, founded by Adrian van der Stel (Governor of the Colony) in I680, and called after himself and his wife, whose 
name was Bosch. It is built in genuine Dutch style, with straight streets of two-storied white houses, the windows nearly flush with the walls as in Holland, the wood-work and the green shutters those of Holland and long lines of dark-green oaks shading the foot-walks on each side the street. Soft. rich pastures all round-for there is plenty of water brought down from the hills-complete the resemblance to a Hobbema landscape; and it is only when one looks up and sees rocky mountains soaring behind into the sky that the illusion is broken. It is here, and in the town of Swellendam, farther east, and in some of the villages that lie northward of Stellenbosch in the western province, that the Dutch element has remained strongest and has best retained its ancient ways and customs.

We have, however, delayed long enough round the capital, and it is time to plunge into the interior by the railway. Sixty miles to the north of Cape Town, the trunk-line, which has threaded its way through the valleys of an outlying range of mountains, reaches the foot of the great inner table-land at a place called Hex River, and in an hour climbs by zigzags up an incline which is in some places as steep as one in thirty-five, mounting 1600 feet into a desert land. Rugged brown mountains, sometimes craggy, sometimes covered with masses of loose stone, rise above the lower ground, now a valley, now an open plain, through which the railway takes its eastward way. The bushes, which had been tall and covered with blossoms on the 
ascent, are now stunted, bearing small and usually withered flowers. Hardly an herb, and not a blade of grass, is to be seen on the ground, which is sometimes of clay, baked hard by the sun, sometimes of sand, without a drop of water anywhere. Yet water flows when, now and then in the summer, a storm breaks, or a few showers come; and then nature revives, and for a week or two flowers spring from the soil and a fresher green comes upon the bushes. In a landscape so arid one hears with surprise that the land is worth ten shillings an acre, for one or two of the smallest shrubs give feed for sheep, and there are wells scattered about sufficient for the flocks. The farms are large, usually of at least six thousand acres, so one seldom sees a farmhouse. The farmers are all of Boer stock. They lead a lonely life in a silent and melancholy nature, but their habitual gravity has not made them unsocial, for they are fond of riding or driving in their waggons to visit one another on all occasions of festivity or mourning. Every ten or fifteen miles there is a station, and here the British element in the population appears, chiefly occupied in storekeeping. At Matjesfontein an enterprising Scotchman has built an hotel and a number of small villas to serve as a health resort; has dug wells, and planted Australian gums for shade, making a little oasis in the desert. Farther east the village of Beaufort West, the only place along the line that aspires to be called a town, boasts a church with a spire, and has one or two streets, though most of its houses 
are stuck down irregularly over a surface covered with broken bottles and empty sardine and preserved meat tins. Here, too, there is a large, shallow pond of water, and here people with weak lungs come to breathe the keen, dry, invigorating air. Of its efficacy there is no doubt, but one would think that the want of society and of variety would be almost as depressing as the air is stimulating. The prospects have a certain beauty, for beyond the wide, bare, greyish-brown plain to the south sharp mountains stand up, which take at sunrise and sunset delightful tints of blue and purple, and the sense of a vast expanse on earth beneath and in heaven above has something strange and solemn. But the monotony of perpetual sunlight upon a landscape which has no foregrounds and never changes, save in colour, must be trying to those who have no occupation except that of getting well.

This Karroo scenery continues, with little variation, for hundreds of miles. To the north of the railway, which runs mostly from west to east, the aspect of the country is much the same, dry, stony, and forbidding, for full three hundred miles to the Orange River, and beyond that into Namaqualand. Except for the few houses at some of the stations, it seems a wilderness; yet here and there stand tiny villages, connected by lines of coach with the railway, whither the neighbouring farmers come to supply their household needs. But as the train moves farther and farther eastward the features of nature grow less austere. The mountains by 
degrees recede or sink; the country becomes more of a great open plain, though with isolated hills visible here and there over its expanse. It is also slightly greener, and after the rains some little grass springs up, besides the low, succulent shrub which the sheep eat. At De Aar Junction, five hundred miles from Cape Town, the line to Bloemfontein and the Transvaal branches off to the right. We follow the western branch over a vast rolling plain to the Orange River, here a perennial stream, and at six hundred and forty-six miles from Cape Town find ourselves once more in the haunts of men at Kimberley.

Kimberley, the city of diamonds, has had a curious history. In 1869-70 the precious crystals, first found in 1867 near the Orange River, were discovered here in considerable quantity. A sudden rush of adventurers from all parts of South Africa, as well as from Europe, gave it in three or four years a population of many thousands. The mining claims were then and for some years afterward in the hands of a large number of persons and companies who had opened them or purchased them. The competition of these independent miner-workers was bringing down the price of the stones, and the waste or leakage arising from the theft of stones by the native work-people, who sold them to European I. D. B. (illicit diamond-buyers), seriously reduced the profits of mining. It was soon seen that the consolidation of the various concerns would effect enormous savings and form the only means of 
keeping up the price of diamonds. The process of amalgamating the claims and interests and merging them in one huge corporation was completed in I 885, chiefly by the skill and boldness of Mr. Cecil J. Rhodes, who had gone to Natal for his health shortly before 1870 , and came up to Kimberley in the first months of the rush. Since the amalgamation, the great corporation called the De Beers Consolidated Mining Company (which now owns nearly all the mines), has reduced the output of diamonds to just such an annual amount as experience has proved that Europe and America-the United States is the chief market-are able to take at a price high enough to leave a large profit. By this means the price has been well maintained. This policy, however, has incidentally reduced the population of Kimberley. One powerful corporation, with its comparatively small staff of employees, has taken the place of the crowd of independent adventurers of the old days, and some of the mines have been closed because the rest are sufficient to produce as many diamonds as it is deemed prudent to put upon the market. Thus there are now only about 10,000 people in the town, and some of the poorer quarters are almost deserted, the stores and taverns, as well as the shanty dwellings, empty and falling to pieces. In the better quarters, however, the old roughness has been replaced by order and comfort. Many of the best villas are embowered in groves of tall Australian gumtrees, while the streets and roads are bordered 
either by gum-trees or by hedges of prickly-pear or agave. The streets are wide, and most of the houses are detached and of one story, built like Indian bungalows; so the town covers an area quite disproportionate to its population, and gives the impression of an extensive city. For the residence of the Europeans employed in the two great mines which the Company works, a suburb called Kenilworth has been built by Mr. Rhodes, where neat houses of four, five, or six rooms each stand in handsome avenues planted with Australian trees, the so-called "beef-wood" and the red gum. They are not beautiful trees, but they have the merit of growing very fast, and any shade is welcome.

The diamonds are found in beds of clay, of which there are two: a yellow and softish clay, lying on or near the surface, and a hard blue clay, lying deeper. These clays, which are usually covered by a thin layer of calcareous rock, are supposed to be the remains of mud-pits due to volcanic action, such as the so-called mud-volcanoes of Iceland, near Námaskard, on the banks of Lake Myvatn, or such as the similar boiling mud-pits of the Yellowstone Park country, called from their brilliant colours the "Paint-pots." It is, at any rate, from circular clay basins inclosed within a harder rock (basalt, black shale, and quartzite) that the stones are obtained. Some of the mines are worked even to a depth of I 200 feet by shafts and subterranean galleries. 
Some are open, and these, particularly that called the Wesselton Mine, are an interesting sight. This deep hollow, one-third of a mile in circumference and 1 oo feet deep, inclosed by a strong fence of barbed wire, is filled by a swarm of active Kafir workmen, cleaving the "hard blue" with pickaxes, piling it up on barrows, and carrying it off to the wide fields; where it is left exposed to the sun and, during three months, to the rain. Having been thus subjected to a natural decomposition, it is the more readily brought by the pickaxe into smaller fragments before being sent to the mills, where it is crushed, pulverized, and finally washed to get at the stones. Nowhere in the world does the hidden wealth of the soil and the element of chance in its discovery strike one so forcibly as here, where you are shown a piece of ground a few acres in extent, and are told, "Out of this pit diamonds of the value of $£$ I 2,000,000 have been taken." Twenty-six years ago the ground might have been bought for f.50.

The most striking sight at Kimberley, and one unique in the world, is furnished by the two socalled "compounds" in which the natives who work in the mines are housed and confined. They are huge inclosures, unroofed, but covered with a wire netting to prevent anything from being thrown out of them over the walls, and with a subterranean entrance to the adjoining mine. The mine is worked on the system of three eight-hour shifts, so 
that the workman is never more than eight hours together underground. Round the interior of the wall there are built sheds or huts, in which the natives live and sleep when not working. A hospital is also provided within the inclosure, as well as a school where the work-people can spend their leisure in learning to read and write. No spirits are sold - an example of removing temptation from the native which it is to be wished that the legislature of Cape Colony would follow. Every entrance is strictly guarded, and no visitors, white or native, are permitted, all supplies being obtained from the store within, kept by the Company. The De Beers mine compound contained at the time of my visit 2,600 natives, belonging to a great variety of tribes, so that here one could see specimens of the different native types, from Natal and Pondoland on the south, to the shores of Lake Tanganyika in the far north. They come from every quarter, attracted by the high wages, usually eighteen to thirty shillings a week, and remain for three months or more, and occasionally even for long periods, knowing, of course, that they have to submit to the precautions which are absolutely needed to prevent them from appropriating the diamonds they may happen to find in the course of their work. To encourage honesty, ten per cent. of the value of any stone which a workman may find is given to him if he brings it himself to the overseer, and the value of the stones on which this ten per cent. is paid is estimated at $£ 400,000$ in each year. Nevertheless, 
a certain number of thefts occur. I heard from a missionary an anecdote of a Basuto who, after his return from Kimberley, was describing how, on one occasion, his eye fell on a valuable diamond in the clay he was breaking into fragments. While he was endeavouring to pick it up he perceived the overseer approaching, and, having it by this time in his hand, was for a moment terribly frightened, the punishment for theft being very severe. The overseer, however, passed on. "And then," said the Basuto, "I knew that there was indeed a God, for he had preserved me."

When the native has earned the sum he wantsand his earnings accumulate quickly, since he can live upon very little-he takes his wages in English sovereigns, a coin now current through all Africa as far as Tanganyika, goes home to his own tribe, perhaps a month's or six weeks' journey distant, buys two oxen, buys with them a wife, and lives happily, or at least lazily, ever after. Here in the vast oblong compound one sees Zulus from Natal, Fingos, Pondos, Tembus, Basutos, Bechuanas, Gungunhana's subjects from the Portuguese territories, some few Matabili and Makalaka, and plenty of Zambesi boys from the tribes on both sides of that great river-a living ethnological collection such as can be examined nowhere else in South Africa. Even Bushmen, or at least natives with some Bushman blood in them, are not wanting. They live peaceably together, and amuse themselves in their several ways during their leisure hours. Be- 
sides games of chance, we saw a game resembling "fox and geese," played with pebbles on a board; and music was being discoursed on two rude native instruments, the so-called "Kafir piano," made of pieces of iron of unequal length fastened side by side in a frame, and a still ruder contrivance of hard bits of wood, also of unequal size, which when struck by a stick emit different notes, the first beginnings of a tune. A very few were reading or writing letters, the rest busy with their cooking or talking to one another. Some tribes are incessant talkers, and in this strange mixing-pot of black men one may hear a dozen languages spoken as one passes from group to group.

The climate of Kimberley is healthy, and even bracing, though not pleasant when a north-west wind from the Kalahari Desert fills the air with sand and dust. Its dryness recommends it as a resort for consumptive patients, while the existence of a cultivated, though small, society makes it a less doleful place of residence than are the sanatoria of the Karroo. The country round is, however, far from attractive. Save on the east, where there rises a line of hills just high enough to catch the lovely lights of evening and give colour and variety to the landscape, the prospect is monotonous in every direction. Like the ocean, this vast plain is so flat that you cannot see how vast it is. Except in the environs of the town, it is unbroken by tree or house, and in a part of those environs the masses of bluish-gray mine refuse that strew the ground 
CHAP.

give a dismal and even squalid air to the foreground of the view. One is reminded of the deserted coalpits that surround Wigan, or the burnt-out and waste parts of the Black Country in South Staffordshire, though at Kimberley there is, happily, no coal-smoke or sulphurous fumes in the air, no cinder on the surface, no coal-dust to thicken the mud and blacken the roads. Some squalor one must have with that disturbance of nature which mining involves, but here the enlightened activity of the Company and the settlers has done its best to mitigate these evils by the planting of trees and orchards, by the taste which many of the private houses show, and by the provision here and there of open spaces for games.

From Kimberley the newly opened railway runs one hundred and fifty miles farther north to Vryburg. till lately the capital of the Crown Colony of British Bechuanaland, annexed in 1895 to Cape Colony, and thence to Mafeking. After a few miles the line crosses the Vaal River, here a respectable stream for South Africa, since it has, even in the dry season, more water than the Cam at Cambridge, or the Cherwell at Oxford-perhaps as much as the Arno at Florence. It flows in a wide, rocky bed, about thirty feet below the level of the adjoining country. The country becomes more undulating as the line approaches the frontiers, first of the Orange Free State, and then of the Transvaal Republic, which bounds that state on the north. Bushes are seen, and presently trees, nearly all prickly mimosas, 
small and unattractive, but a pleasant relief from the bare flats of Kimberley, whence all the wood that formerly grew there has been taken for mine props and for fuel. There is more grass, too, and presently patches of cultivated land appear, where Kafirs grow maize, called in South Africa "mealies." Near the village of Taungs ${ }^{1}$ a large native reservation is passed, where part of the Batlapin tribe is settled, and here a good deal of ground is tilled, though in September, when no crop is visible, one scarcely notices the fields, since they are entirely unenclosed, mere strips on the veldt, a little browner than the rest, and with fewer shrublets on them. But the landscape remains equally featureless and monotonous, redeemed only, as evening falls, by the tints of purple and violet which glow upon the low ridges or swells of ground that rise in the distance. Vryburg is a cheerful little place of brick walls and corrugatediron roofs; Mafeking another such, still smaller, and, being newer, with a still larger proportion of shanties to houses. At Mafeking, eight hundred and seventyfive miles from Cape Town, the railway ended in I 895 (though now, in January, I897, it is being opened to the hamlet of Gaberones [pronounced "Haberoons"], ninety-six miles farther north). Here ends also the territory of Cape Colony, the rest of Bechuanaland to the north and west forming the so-called Bechuanaland Protectorate, which in

${ }^{1}$ Here, in December, 1896 , the natives rose in revolt, exasperated by the slaughter of their cattle, though that slaughter was the only method of checking the progress of the cattle-plague. 
October, I895, was handed over by the Colonial Office, subject to certain restrictions and provisions for the benefit of the natives, to the British South Africa Company, within the sphere of whose operations it had, by the charter of 1890 , been included. After the invasion of the Transvaal Republic by the expedition led by Dr. Jameson, which started from Pitsani, a few miles north of Mafeking, in December, I 895, this transfer was recalled, and Bechuanaland is now again under the direct control of the High Commissioner for South Africa as representing the British Crown. It is administered by magistrates, who have a force of police at their command, and by native chiefs, the most powerful and famous of whom is Khama.

Close to Mafeking itself there was living a chieftain whose long career is interwoven with many of the wars and raids that went on between the Boers and the natives from I 840 to I 885 -Montsioa (pronounced "Montsiwa"), the head of a tribe of Barolongs. We were taken to see him, and found him sitting on a low chair under a tree in the midst of his huge native village, dressed in a red flannel shirt, a pair of corduroy trousers, and a broad gray felt hat with a jackal's tail stuck in it for ornament. His short, woolly hair was white, and his chocolatecoloured skin, hard and tough like that of a rhinoceros, was covered with a fretwork of tiny wrinkles, such as one seldom sees on a European face. He was proud of his great age (eighty-five), and recalled the names of several British governors and generals 
during the last seventy years. But his chief interest was in inquiries (through his interpreter) regarding the Queen and events in England, and he amused his visitors by the diplomatic shrewdness with which, on being told that there had been a change of government in England, and a majority in favour of the new government, he observed, "They have made a mistake; they could not have had a better government than the old one." He was a wealthy man, owning an immense number of the oxen which used to carry on (for the cattle-plague has now carried off most of them) the transport service between Mafeking and Bulawayo; and, from all I could learn, he ruled his people well, following the counsels of the British government, which in I 885 delivered him out of the hands of the Boers. $\mathrm{He}$ died in the middle of 1896 .

At Mafeking we bade farewell to the railway, and prepared to plunge into the wilderness. We travelled in a light American waggon, having a Cape Dutchman as driver and a coloured "Cape boy" to help him, but no other attendants. The waggon had a small iron tank, which we filled with water that had been boiled to kill noxious germs, and with this we made our soup and tea. For provisions we carried biscuits, a little tinned soup and meat, and a few bottles of soda-water. These last proved to be the most useful part of our stores, for we found the stream- or well-water along the route undrinkable, and our mouths were often so parched that it was only by the help of sips of soda-water that we could 
manage to swallow the dry food. At the European stores which occur along the road, usually at intervals of thirty or forty miles, though sometimes there is none for sixty miles or more, we could often procure eggs and sometimes a lean chicken; so there was enough to support life, though we seldom got what is called in America "a square meal."

Northward from Mafeking the country grows pretty. At first there are trees scattered picturesquely over the undulating pastures and sometimes forming woods-dry and open woods, yet welcome after the bareness which one has left behind. Here we passed the tiny group of houses called Pitsani,

$x$ little dreaming that three months later it would become famous as the place where the Matabililand police were marshalled, and from which they started on their ill-starred march into the Transvaal, whose hills we saw a few miles away to the east. Presently the ground becomes rougher, and the track winds among and under a succession of abrupt kopjes (pronounced "koppies"), mostly of granitic or gneissose rock. One is surprised that a heavy coach, and still heavier waggons, can so easily traverse such a country, for the road is only a track, for which art has done nothing save in cutting a way through the trees. It is one of the curious features of South Africa that the rocky hills have an unusual faculty for standing detached enough from one another to allow wheeled vehicles to pass between them, and the country is so dry that 
morasses, the obstacle which a driver chiefly fears in most countries, are here, for three-fourths of the year, not feared at all. This region of bold, craggy hills, sparsely wooded, usually rising only some few hundred feet out of the plateau itself, which is about 4,000 feet above the sea, continues for about thirty miles. To it there succeeds a long stretch of flat land along the banks of the sluggish Notwani, the

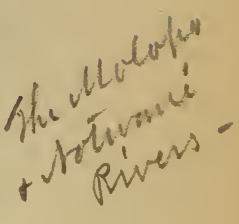
only perennial river of these parts; for the stream which on the map bears the name of Molopo, and runs away west into the desert to lose nearly all of its water in the sands, is in September dry, and one crosses its channel without noticing it. This Notwani, whose course is marked by a line of trees taller and greener than the rest, is at this season no better than a feeble brook, flowing slowly, with more mud than water. But it contains not only goodsized fish, the catching of which is the chief holiday diversion of these parts, but also crocodiles, which, generally dormant during the season of low water, are apt to obtrude themselves when they are least expected, and would make bathing dangerous, were there any temptation to bathe in such a thick green fluid. That men as well as cattle should drink it seems surprising, yet they do,-Europeans as well as natives,-and apparently with no bad effects. Below Palla, one hundred and ninety-five miles north of Mafeking, the Notwani joins the Limpopo, or Crocodile River, a much larger stream, which has come down from the Transvaal hills, and winds for nearly a thousand miles to the north and east 
before it falls into the Indian Ocean. It is here nearly as wide as the Thames at Henley, fordable in some places, and flowing very gently. The country all along this part of the road is perfectly flat, and just after the wet season very feverish, but it may be traversed with impunity from the end of May till December. It is a dull region-everywhere the same thin wood, through which one can see for about a quarter of a mile in every direction, consisting of two or three kinds of mimosa, all thorny, and all so spare and starved in their leafage that one gets little shade beneath them when at the midday halt shelter has to be sought from the formidable sun. On the parched ground there is an undergrowth of prickly shrubs, among which it is necessary to move with as much care as is needed in climbing a barbed-wire fence. When at night, camping out on the veldt, one gathers brushwood to light the cooking-fire, both the clothes and the hands of the novice come badly of. Huge ant-hills begin to appear, sometimes fifteen to twenty feet high and as many yards in circumference; but these large ones are all dead and may be of considerable age. In some places they are so high and steep, and stand so close together, that by joining them with an earthen rampart a strong fort might be made. When people begin to till the ground more largely than the natives now do, the soil heaped up in these great mounds will be found most serviceable. It consists of good mould, very friable, and when spread out over the surface ought to prove 
fertile. In pulverizing the soil, the ants render here much the same kind of service which the earthworms do in Europe. There are no flowers at this season (end of September), and very little grass ; yet men say that there is no better ranching country in all South Africa, and the oxen which one meets all the way, feeding round the spots where the transportwaggons have halted, evidently manage to pick up enough herbage to support them. The number of i ox-waggons is surprising in so lonely a country, till one remembers that most of the food and drink, as well as of the furniture, agricultural and mining tools, and wood for building,-indeed, most of the necessaries and all the luxuries of life needed in Matabililand,- -have to be sent up along this road, which is more used than the alternative route through the Transvaal from Pretoria via Pietersburg. No wonder all sorts of articles are costly in Bulawayo, when it has taken eight or ten weeks to bring them from the nearest railway terminus. The waggons do most of their journeying by night, allowing the oxen to rest during the heat of the day. One of the minor troubles of travel is the delay which ensues when one's vehicle meets a string of waggons, sometimes nearly a quarter of a mile long, for each has eight, nine, or even ten, span of oxen. They move very slowly, and at night, when the track happens to be a narrow one among trees, it is not easy to get past. Except for these waggons the road is lonely. One sees few natives, though the narrow foot-paths crossing the wheel-track show that the 
CHAP.

country is inhabited. Here and there one passes a large native village, such as Ramoutsie and Machudi, but small hamlets are rare, and solitary huts still rarer. The country is of course very thinly peopled in proportion to its resources, for, what with the good pasture nearly everywhere and the fertile land in many places, it could support eight or ten times the number of Barolongs, Bamangwato, and other Bechuanas who now live scattered over its vast area. It is not the beasts of prey that are to blame for this, for, with the disappearance of game, lions have become extremely scarce, and leopards and lynxes are no longer common. Few quadrupeds are seen, and not many kinds of birds. Vultures, hawks, and a species something like a magpie, with four pretty white patches upon the wings and a long tail, are the commonest, together with bluish-gray guinea-fowl, pigeons, and sometimes a small partridge. In some parts there are plenty of bustards, prized as dainties, but we saw very few. Away from the track some buck of the commoner kinds may still be found, and farther to the west there is still plenty of big game in the Kalahari Desert. But the region which we traversed is almost as unattractive to the sportsman as it is to the lover of beauty. It is, indeed, one of the dullest parts of South Africa.

The next stage in the journey is marked by Palapshwye, Khama's capital. This is the largest native town south of the Zambesi, for it has a population estimated at over 20,000 . It came 
into being only a few years ago, when Khama, having returned from the exile to which his father had consigned him on account of his steadfast adherence to Christianity, and having succeeded to the chieftainship of the Bamangwato, moved the tribe from its previous dwelling-place at Shoshong, some seventy miles to the south-west, and fixed it here. Such migrations and foundations of new towns are not uncommon in South Africa, as they were not uncommon in India in the days of the Pathan and Mogul sovereigns, when each new occupant of the throne generally chose a new residence to fortify or adorn. Why this particular site was chosen I do not know. It stands high, and is free from malaria, and there are springs of water in the craggy hill behind; but the country all round is poor, rocky in some places, sandy in others, and less attractive than some other parts of Bechuanaland. We entered the town late at night, delayed by the deep sand on the track, and wandered about in the dark for a long while before, after knocking at one hut after another, we could persuade any native to come out and show us the way to the little cluster of European dwellings. The Kafirs are terribly afraid of the night, and fear the ghosts, which are to them the powers of darkness, more than they care for offers of money.

Khama was absent in England, pressing upon the Colonial Office his objections to the demand made by the British South Africa Company that his kingdom should be brought within the scope of 
CHAP.

their administration and a railway constructed through it from Mafeking to Bulawayo. Besides the natural wish of a monarch to retain his authority undiminished, he was moved by the desire to keep his subjects from the use of intoxicating spirits, a practice which the establishment of white men among them would make it difficult, if not impossible, to prevent. The main object of Khama's life and rule has been to keep his people from intoxicants. His feelings were expressed in a letter to a British commissioner, in which he said: "I fear Lo Bengula less than I fear brandy. I fought against Lo Bengula and drove him back. He never gives me a sleepless night. But to fight against drink is to fight against demons and not men. I fear the white man's drink more than the assagais of the Matabili, which kill men's bodies. Drink puts devils into men and destroys their souls and bodies." Though a Christian himself, and giving the missionaries in his dominions every facility for their work, he has never attempted to make converts by force. A prohibition of the use of alcohol, however, has seemed to him to lie "within the sphere of governmental action," and he has, indeed, imperilled his throne by efforts to prevent the Bamangwato from making and drinking the stronger kind of Kafir beer, to which, like all natives, they were much addicted. ${ }^{1}$ This beer is made from the so-called "Kafir-corn" (a grain

1 There is also a weaker kind made, intoxicating only if consumed in very large quantity. 
resembling millet, commonly cultivated by the natives), and, though less strong than Europeanmade spirits, is more intoxicating than German or even English ale. Khama's prohibition of it had, shortly before my visit, led to a revolt and threatened secession of a part of the tribe under his younger brother, Radiclani, and the royal reformer (himself a strict total abstainer), had been compelled to give way, lamenting, in a pathetic speech, that his subjects would not suffer him to do what was best for them. Just about the same time, in England, the proposal of a measure to check the use of intoxicating liquors led to the overthrow of a great party and clouded the prospects of any temperance legislation. Alike in Britain and in Bechuanaland it is no light matter to interfere with a people's favourite indulgences. European spirits are, however, so much more deleterious than Kafir beer that Khama still fought hard against their introduction. The British South Africa Company forbids the sale of intoxicants to natives in its territory, but Khama naturally felt that when at railway-stations and stores spirits were being freely consumed by whites the difficulty of keeping them from natives would be largely increased. The Colonial Office gave leave for the construction of the railway, and brought Khama into closer relations with the Company, while securing to him a large reserve and establishing certain provisions for his benefit and that of his people. However, a few months later (in the beginning of I896) the extension of the Company's 
CHAP.

powers as to Bechuanaland was recalled, and Khama is now under the direct protection of the Imperial Government.

His kingdom covers on the map a vast but ill-defined area, stretching on the west into the Kalahari Desert, and on the north-west into the thinly peopled country round Lake Ngami, where various small tribes live in practical independence. Sovereignty among African natives is tribal rather than territorial. Khama is the chief of the Bamangwato rather than ruler of a country, and where the Bamangwato dwell there Khama reigns. A large proportion of them dwell in or near Palapshwye. Born about 1830, he is by far the most remarkable Kafir now living in South Africa, for he has shown a tact, prudence, and tenacity of purpose which would have done credit to a European statesman. He was converted to Christianity while still a boy, and had much persecution to endure at the hands of his heathen father, who at last banished him for refusing to take a second wife. What is not less remarkable, he has carried his Christianity into practice, evincing both a sense of honour as well as a humanity which has made him the special protector of the old and the weak, and even of the Bushmen who serve the Bamangwato. Regarded as fighters, his people are far inferior to the Matabili, and he was often in danger of being overpowered by the fierce and rapacious Lo Bengula. As early as I 862 he crossed assagais with and defeated a Matabili impi (war-band), earning the 
praise of the grim Mosilikatze, who said, "Khama is a man. There is no other man among the Bamangwato." Though frequently thereafter threatened and sometimes attacked, he succeeded, by his skilful policy, in avoiding any serious war until the fall of Lo Bengula in 1893 . Seeing the tide of white conquest rising all round him, he has had a difficult problem to face, and it is not surprising that he has been less eager to welcome the Company and its railway than those who considered him the white man's friend had expected. The coming of the whites means not only the coming of liquor, but the gradual occupation of the large open tracts where the natives have hunted and pastured their cattle, and a change in their mode of life, which, inevitable as it may be, a patriotic chief must naturally wish to delay.

Palapshwye, the largest native town south of the Zambesi, is an immense mass of huts, planted without the smallest attempt at order over the sandy hill slope, some two square miles in extent. The huts are small, with low walls of clay and roofs of grass, so that from a distance the place looks like a wilderness of beehives. Each of the chief men has his own hut and those of his wives inclosed in a rough fence of thorns, or perhaps of prickly-pear, and between the groups of huts lie open spaces of sand or dusty tracks. In the middle of the town, close to the huts of Khama himself, who, however, being a Christian, has but one wife, stands the great kraal or kothla. It is an inclosure some three 
hundred yards in circumference, surrounded by a stockade ten feet high, made of dry trunks and boughs of trees stuck in the ground so close together that one could not even shoot a gun, or hurl an assagai through them. The stockade might resist the first attack of native enemies if the rest of the town had been captured, but it would soon yield to fire. In the middle of it stands the now dry trunk of an old tree, spared when the other trees were cut down to make the kraal, because it was supposed to have magical powers, and heal those who touched it. A heap of giraffe skins lay piled against it, but its healing capacity now finds less credit, at least among those who wish to stand well with the chief. Within this inclosure Khama holds his general assemblies when he has some address to deliver to the people or some ordinance to proclaim. $\mathrm{He}$ administers criminal justice among his subjects, and decides their civil disputes, usually with the aid of one or two elderly counsellors. He has tried to improve their agricultural methods, and being fond of horses has formed a good stud. Unhappily, in 1896, the great murrain descended upon the Bamangwato, and Khama and his tribe have lost nearly all the cattle (said to have numbered eight hundred thousand) in which their wealth consisted.

The British magistrate - there are about seventy Europeans living in the town-described these Bechuanas as a quiet folk, not hard to manage. They have less force of character and much less taste for fighting than Zulus or Matabili. The main 
impression which they leave on a stranger is that of laziness. Of the many whom we saw hanging about in the sun, hardly one seemed to be doing any kind of work. Nor do they. They grow a few mealies (maize), but it is chiefly the women who hoe and plant the ground. They know how to handle wire and twist it round the handles of the sjamboks (whips of hippopotamus hide). But having few wants and no ambition, they have practically no industries, and spend their lives in sleeping, loafing, and talking. When one watches such a race, it seems all the more strange that a man of such remarkable force of character as Khama should suddenly appear among them. ${ }^{1}$

For about sixty miles north-eastward from Palapshwye the country continues dull, dry, and mostly level. After that rocky hills appear, and in the beds of the larger streams a little water is seen. At Tati, ninety miles from Palapshwye (nearly four hundred from Mafeking), gold reefs have been worked at intervals for five and twenty years, under a concession originally granted (in I869), by Lo Bengula, and a little European settlement has grown up. Here one passes from Bechuanaland into the territories which belonged to the Matabili, and now to the British South Africa Company. The country rises and grows more picturesque. The grass is greener on the pastures. New trees appear, some

1 For most of what is here stated regarding Khama I an indebted to an interesting little book by the late Bishop KnightBruce, entitled Khama, an African Chief. 
of them bearing beautiful flowers, and the air is full of tales of lions. For, in Africa, where there is more grass there is more game, and where there is more game there are more beasts of prey. Lions, we were told, had last week dragged a Kafir from beneath a waggon where he was sleeping. Lions had been seen yester eve trotting before the coach. Lions would probably be seen again to-morrow. But to us the beast was always a lion of yesterday or a lion of to-morrow, never a lion of to-day. The most direct evidence we had of his presence was when, some days later, we were shown a horse on which that morning a lion had sprung, inflicting terrible wounds. The rider was not touched, and galloped the poor animal back to camp. At Mangwe, a pretty little station with exceptionally bad sleeping quarters, the romantic part of the country may be said to begin. All round there are rocky kopjes, and the track which leads northward follows a line of hollows between them, called the Mangwe Pass, a point which was of much strategical importance in the Matabili war of 1893 , and has been again of so much importance in the recent native rising (1896) that one of the first acts of the British authorities was to construct a rough fort in it and place a garrison there. Oddly enough, the insurgents did not try to occupy it, and thereby cut off the English in Matabililand from their railway base at Mafeking, the reason being, as I was informed, that the Molimo, or prophet, whose incitements contributed to the insurrection, had told them that it was 
by the road through this pass that the white strangers would quit the country for ever.

A more peaceful spot could not be imagined than the pass was when we passed through it at 5 A.M., "under the opening eyelids of the dawn." Smooth green lawns, each surrounded by a fringe of wood, and filled with the songs of awakening birds, lay beneath the beetling crags of granite,-granite whose natural gray was hidden by brilliant red and yellow lichens,- - and here and there a clear streamlet trickled across the path. Climbing to the top of one of these rocky masses, I enjoyed a superb view to north, west, and east, over a wilderness of rugged hills, with huge masses of gray rock rising out of a feathery forest, while to the north the undulating line, faintly blue in the far distance, marked the point where the plateau of central Matabililand begins to decline toward the valley of the Zambesi. It was a beautiful prospect both in the wild variety of the foreground and in the delicate hues of ridge after ridge melting away towards the horizon, and it was all waste and silent, as it has been since the world began.

The track winds through the hills for some six or eight miles before it emerges on the more open country. These kopjes, which form a sort of range running east-south-east and west-north-west, are the Matoppo Hills, in which the main body of the Matabili and other insurgent natives held their ground during the months of April, May and June, I896. Although the wood is not dense, by no 
means so hard to penetrate as the bush or low scrub which baffled the British troops in the early Kaffir wars, waged on the eastern border of Cape Colony, still the ground is so very rough, and the tumbled masses of rock which lie round the foot of the granite kopjes afford so many spots for hiding, that the agile native, who knows the ground, had a far better chance against the firearms of the white men than he could have had in the open country where the battles of 1893 took place. Seeing such a country one can well understand that it was quite as much by famine as by fighting that the rising of 1896 was brought to an end.

From the northern end of the Mangwe Pass it is over forty miles to Bulawayo, the goal of our journey, and the starting-point for our return journey to the coast of the Indian Ocean. But Bulawayo is too important a place to be dealt with at the end of a chapter already sufficiently long. 


\section{CHAPTER XV}

FROM BULAWAYO TO FORT SALISBURY - MATABILILAND AND MASHONALAND

Bulawayo means, in the Zulu tongue, the place of slaughter, and under the sway of Lo Bengula it deserved its name. Just sixty years ago Mosilikatze, chief of the Matabili, driven out of what is now the Transvaal Republic by the Dutch Boers who had emigrated from Cape Colony, fled four hundred miles to the north-west and fell like a sudden tempest upon the Makalakas and other feeble tribes who pastured their cattle in this remote region. His tribe was not large, but every man was a tried warrior. The Makalakas were slaughtered or chased away or reduced to slavery, and when Mosilikatze died in 1870, his son Lo Bengula succeeded to the most powerful kingdom in South Africa after that of Cetewayo, chief of the Zulus. Of the native town which grew up round the king's kraal there is now not a trace-all was destroyed in 1893. The kraal itself, which Lo Bengula fired when he fled away, has gone, and only one old tree marks the spot where the king used to sit administer- 
ing justice to his subjects. A large part of this justice consisted in decreeing death to those among his indunas or other prominent men who had excited his suspicions or whose cattle he desired to appropriate. Sometimes he had them denounced"smelt out," they called it-by the witch-doctors as guilty of practising magic against him. Sometimes he dispensed with a pretext, and sent a messenger to the hut of the doomed man to tell him the king wanted him. The victim, often ignorant of his fate, walked in front, while the executioner, following close behind, suddenly dealt him with the knobkerry, or heavy-ended stick, one tremendous blow, which crushed his skull and left him dead upon the ground. Women, on the other hand, were strangled. ${ }^{1}$ No one disputed the despot's will, for the Matabili, like other Zulus, show to their king the absolute submission of soldiers to their general, while the less martial tribes, such as the Bechuanas and Basutos, obey the chief only when he has the sentiment of the tribe behind him. One thing, however,

1 A singular story was told me regarding the death of Lo Bengula's sister. She had enjoyed great influence with him, but when he took to wife the two daughters of Gungunhana, the great chief (of Zulu stock) who lived to the eastward beyond the Sabi River, she resented so bitterly the precedence accorded to them as to give the king constant annoyance. At last, after several warnings, he told her that if she persisted in making herself disagreeable he would have her put to death. Having consulted the prophet of the Matoppo Hills, who told her she would be killed, she cheerfully accepted this way out of the difficulty, and was accordingly sent away and strangled. 
the king could not do. He owned a large part of all the cattle of the tribe, and he assumed the power to grant concessions to dig for minerals. But the land belonged to the whole tribe by right of conquest, and he had no power to alienate it.

Moved by the associations of the ancient capital, Mr. Rhodes directed the residence of the Administrator, Government House, as it is called, to be built on the site of Lo Bengula's kraal. But the spot was not a convenient one for the creation of a European town, for it was a good way from any stream, and there was believed to be a valuable gold-reef immediately under it. Accordingly, a new site was chosen, on somewhat lower ground, about two miles to the south-west. Here new Bulawayo stands, having risen with a rapidity rivalling that of a mining-camp in western America. The site has no natural beauty, for the landscape is dull, with nothing to relieve its monotonous lines except the hill-of Tsaba Induna, about fifteen miles distant to the east. The ground on which the town stands, sloping gently to the south, is bare, dusty, and wind-swept, like the country all round. However, the gum-trees, planted in the beginning of I894, when the streets were laid out, had already shot up to twelve or fifteen feet in height and began to give some little shade. Brick houses were rising here and there among the wooden shanties and the sheds of corrugated iron. An opera house was talked of, and already the cricket-ground and race-course, without which Englishmen cannot be happy, had been laid 
out. Town lots, or "stands," as they are called in South Africa, had gone up to prices which nothing but a career of swift and brilliant prosperity could justify. However, that prosperity seemed to the inhabitants of Bulawayo to be assured. Settlers kept flocking in. Storekeepers and hotel-keepers were doing a roaring trade. Samples of ore were every day being brought in from newly explored gold-reefs, and all men's talk was of pennyweights, or even ounces, to the ton. Everybody was cheerful, because everybody was hopeful. It was not surprising. There is something intoxicating in the atmosphere of a perfectly new country, with its undeveloped and undefined possibilities; and the easy acquisition of this spacious and healthful land, the sudden rise of this English town where two years before there had been nothing but the huts of squalid savages, had filled every one with a delightful sense of the power of civilized man to subjugate the earth and draw from it boundless wealth. Perhaps something may also be set down to the climate. Bulawayo is not beautiful. Far more attractive sites might have been found among the hills to the south. But it has a deliciously fresh, keen brilliant air, with a strong breeze tempering the sun-heat, and no risk of fever. Indeed, nearly all this side of Matabililand is healthful, partly because it has been more thickly peopled of late years than the eastern side of the country, which was largely depopulated by the Matabili raids.

Next to the prospects of the gold-reefs (a topic to 
which I shall presently return), the question in which a visitor in 1895 felt most interest was the condition of the natives. It seemed too much to expect that a proud and warlike race of savages should suddenly, within less than two years from the overthrow of their king, have abandoned all notion of resistance to the whites and settled down as peaceable subjects. The whites were a mere handful scattered over an immense area of country, and the white police force did not exceed four or five hundred men. Nevertheless, the authorities of the British South Africa Company were of opinion that peace had been finally secured, and that no danger remained from the natives. They observed that, while the true Matabili who remained in the country-for some had fled down to or across the Zambesi after the defeats of 1893-were comparatively few in number, the other natives, mostly Makalakas, ${ }^{1}$ were timid and unwarlike. They held that when a native tribe has been once completely overcome in fight, it accepts the inevitable with submission. And they dwelt on the fact that Lo Bengula's tyranny had been a constant source of terror to his own subjects. After his flight some

${ }_{1}$ The original inhabitants of the country, belonging to the tribes which we, following the Portuguese, call Makalanga or Makalaka, are called by the Matabili (themselves Zulus) Masweni. The name Maholi, often also applied to them, is said to mean "outsiders," i.e., non-Zulus. Though many had been drafted as boys into the Matabili regiments, and others were used as slaves, many more dwelt in the country west and north-west of Bulawayo. Mashonaland, to the east, is peopled by cognate tribes. 
of his leading indunas came to Dr. Jameson and said, "Now we can sleep." This confidence was shared by all the Europeans in the country. English settlers dwelt alone without a shade of apprehension in farms, six, eight, or ten miles from another European. In the journey I am describing from Mafeking to Fort Salisbury, over eight hundred miles of lonely country, my wife and I were accompanied only by my driver, a worthy Cape Dutchman named Renske, and by a native "Cape boy." None of us was armed, and no one of the friends we consulted as to our trip even suggested that I should carry so much as a revolver, or that the slightest risk was involved in taking a lady through the country. How absolutely secure the Administrator at Bulawayo felt was shown by his sending the Matabililand mounted police to Pitsani, in southern Bechuanaland, in November, leaving the country denuded of any force to keep order.

It is easy to be wise after the event. The confidence of the Europeans in the submissiveness of the natives is now seen to have been ill founded. Causes of discontent were rife among them, which, at first obscure, have now (I897) become pretty clear. Two of these causes were already known at the time of my visit, though their seriousness was underestimated. In Mashonaland the natives disliked the tax of ten shillings for each hut, which there, as in the Transvaal Republic, ${ }^{1}$ they have

1 A hut is usually allotted to each wife, and thus this impost falls heavily on the polygamist chief, being, in fact, a tax upon 
been required to pay; and they complained that it was apt to fall heavily on the industrious Kafir, because the idle one escaped, having nothing that could be taken in payment of it. This tax was sometimes levied in kind, sometimes in labour, but by preference in money when the hut-owner had any money, for the Company desired to induce the natives to earn wages. If he had not, an ox was usually taken in pledge. In Matabililand many natives, I was told, felt aggrieved that the Company had claimed the ownership of and the right to take to itself all the cattle, as having been (in the Company's view) the property of Lo Bengula, although many of these had, in fact, been left in the hands of the indunas, and a large part were, in December, I 895, distributed among the natives as their own property. Subsequent inquiries have shown that this grievance was deeply and widely felt. As regards the land, there was evidently the material out of which a grievance might grow, but the grievance did not seem to have yet actually arisen. The land was being sold off in farms, and natives squatting on a piece of land so sold might be required by the purchaser to clear out. However, pains were taken, I was told, to avoid including native villages in any farm sold. Often it would not be for the purchaser's interest to eject the natives, because he might get labourers among them,

luxuries. I was told that in the Transvaal some of the richer natives were trying to escape it by putting two wives in the same hut. 
and labour is what is most wanted. Two native reservations had been laid out, but the policy of the Company was to keep the natives scattered about among the whites rather than mass them in the reservations. Under Lo Bengula there had been no such thing as private ownership of land. The land was "nationalized," and no individual Kafir was deemed to have any permanent and exclusive right even to the piece of it which he might be at the time cultivating. While he actually did cultivate he was not disturbed, for the simple reason that there was far more land than the people could or would cultivate. The natives, although they till the soil, are still half-nomads. They often shift their villages, and even when the village remains they seldom cultivate the same patch for long together. Though Europeans had been freely buying the land, they bought largely to hold for a rise and sell again, and comparatively few of the farms bought had been actually stocked with cattle, while, of course, the parts under tillage were a mere trifle. Hence there did not seem to have been as yet any pressure upon the natives, who, though they vastly outnumber the Europeans, are very few in proportion to the size of the country. I doubt if in the whole territory of the Company south of the Zambesi River there are $1,000,000$. To these possible sources of trouble there was added one now perceived to have been still graver. Native labour was needed not only for public works, but by private persons for mining operations. As the number of 
Kafirs who came willingly was insufficient, the indunas were required to furnish stout young men to work, and according to Mr. Selous, ${ }^{1}$ who was then living in the country, force was often used to bring them in. Good wages were given; but the regulations were irksome, and the native police, who were often employed to bring in the labourers, seem to have abused their powers. To the genuine Matabili, who lived only for war and plunder, and had been accustomed to despise the other tribes, work, and especially mine work, was not only distasteful, but degrading. They had never been really subdued. In 1893 they hid away most of the firearms they possessed, hoping to use them again. Now, when their discontent had increased, two events hastened an outbreak. One was the removal of the white police to Pitsani. Only

1 See his book, published in the end of 1896 , entitled Sunshine and Storm in Rhodesia. I do not gather from it how far, in his opinion, what went on was known to the higher officials.

Since the above lines were written an important report by Sir Richard Martin has been presented to Parliament, in which he states that although there was no regulation allowing forced labour, force was, in fact, used to bring the natives from their kraals to work, and that the irritation thus caused did much to provoke the outbreak. The Company in a reply which they have published do not admit this. I have no data, other than the Report, for pronouncing an opinion on the responsibility of the officials, but there seems to be no doubt that, both in this and in other respects, many of the native police behaved badly, and that the experiment of employing them, which seemed to have much to recommend it, did in fact fail. 
CHAP.

forty-four were left in Matabililand to keep order. The other was the appearance of a frightful murrain among the cattle, which made it necessary for the Company to order the slaughter even of healthy animals in order to stop the progress of the contagion. The plague had come slowly down through German and Portuguese East Africa, propagated, it is said, by the wild animals, especially buffaloes. Some kinds of wild game are as liable to it as domesticated oxen are, and on the Upper Zambesi in September, I896, so large a part of the game had died that the lions, mad with hunger, were prowling round the native kraals and making it dangerous to pass from village to village. This new and unlooked-for calamity created a ferment in the minds of the natives. The slaughter of their cattle seemed to them an act of injustice. Just when they were terrified at this calamity (which, it was reported, had been sent up among them by Lo Bengula or his ghost, from the banks of the Zambesi) and incensed at this apparent injustice, coming on the top of their previous visitation, the news of the defeat and surrender of the Company's police force in the Transvaal spread among them. They saw the white government defenceless, and its head, Dr. Jameson, whose kindliness had impressed those who knew him personally, no longer among them. Then, under the incitements of a prophet, came the revolt.

This, however, is a digression. In October, I 895, we travelled, unarmed and unconcerned, by night as well as by day, through villages where five 
months later the Kafirs rose and murdered every European within reach. So entirely unsuspected was the already simmering disaffection.

The native question which occupied Bulawayo in September, 1895, was that native-labour question which, in one form or another, is always present to South African minds. All hard labour, all rough and unskilled labour, is, and, owing to the heat of the climate as well as the scarcity of white men, must be, done by blacks; and in a new country like Matabililand the blacks, though they can sometimes be induced to till the land, are most averse to working under ground. They are only beginning to use money, and they do not want the things which money buys. The wants of a native living with his tribe and cultivating mealies or Kafir corn are confined to a kaross (skin cloak) or some pieces of cotton cloth. The prospect of leaving his tribe to go and work in a mine, in order that he may earn wages wherewith he can buy things he has no use for, does not at once appeal to him. The white men, anxious to get to work on the gold-reefs, are annoyed at what they call the stupidity and laziness of the native, and usually clamour for legislation to compel the natives to come and work, adding, of course, that regular labour would be the best thing in the world for the natives. Some go so far as to wish to compel them to work at a fixed rate of wages, sufficient to leave a good profit for the employer. Others go even further, and as experience has shown that the native does not fear imprison- 
ment as a penalty for leaving his work, desire the infliction of another punishment which he does fear - that is, the lash. Such monstrous demands seem fitter for the mouths of Spaniards in the sixteenth century than for Englishmen in the nineteenth. The difficulty of getting labour is incident to a new country, and must be borne with. In German East Africa it has been so much felt that the Administrator of that region has proposed to import Indian labour, as the sugar-planters of Natal and as those of Trinidad and Demerara in the West Indies have already done. But it is to some extent a transitory difficulty. The mines at Kimberley succeed in drawing plenty of native labour; so do the mines on the Witwatersrand; so in time the mine-owners in Matabililand may hope to do also. They must, however, be prepared, until a regular afflux of labourers has been set up, to offer, as the Kimberley people do, wages far in excess of anything the Kafirs could possibly gain among their own people, in order to overcome the distaste of the native-a very natural distaste, due to centuries of indolence in a hot climate-to any hard and continuous toil. This is no great compensation to make to those whose land they have taken and whose primitive way of life they have broken up and for ever destroyed. But once the habit of coming to work for wages has been established in these northern regions,and it need not take many years to establish it,the mining companies will have no great difficulty in getting as much labour as they want, and will not 
be obliged, as they now are, to try to arrange with a chief for the despatch of some of his "boys."

Bulawayo is the point from which one starts to visit the Victoria Falls on the Zambesi, the only very grand natural object which South Africa has to show. The expedition, however, is a much longer one than a glance at the map would suggest. Owing to the prevalence of the tsetse-fly in the valley of the great river, one cannot take oxen without the prospect of losing them, and must therefore travel on foot or with donkeys. The want of a waggon makes camping out much more troublesome and involves a large force of native porters. Thus elaborate preparations are needed, and though the distance, as the crow flies, from Bulawayo to the Falls is only some two hundred miles, at least six weeks are needed for the trip, a space of time we could not spare.

I have described in the last chapter the route from Cape Town to the capital of Matabililand which persons coming from England would naturally take. It is not, however, by any means the shortest route to the sea, and it is therefore not the route along which the bulk of the European trade is likely in future to pass. From Cape Town to Bulawayo it is thirteen hundred and eighty miles; but from Bulawayo to the port of Beira, on the Indian Ocean, it is only six hundred and fifty miles via Fort Salisbury and Mtali, and will be only about five hundred if a more direct railway line should ever be laid out. I propose to take the 
reader back to the sea at Beira by this Fort Salisbury and Mtali route, and in following it he will learn something about Mashonaland and the mountains which divide British from Portuguese territory.

Bulawayo is distant from Fort Salisbury two hundred and eighty miles. The journey takes by coach four days and four nights, travelling night and day, with only short halts for meals. An oxwaggon accomplishes it in about three weeks. The track runs nearly all the way along high ground, open, breezy, and healthful because dry, but seldom picturesque. It is a land of rolling downs, the tops of which are covered with thin grass, while better pastures, and sometimes woods also, are found in the valleys of the streams and on the lower slopes of the hills: The first part of the way, from Bulawayo to the little town of Gwelo, is rather dull. One crosses the Bimbezi River, where the Matabili were finally overthrown in the war of 1893 , and the Shangani ${ }^{1}$ River, where they suffered their first defeat. The Company's force was advancing along the high open ground to attack Bulawayo, and the native army met them on the road. Both battlefields are bare and open, and one wonders at the folly of the natives who advanced over such ground, exposed to the rifle-fire and the still more deadly Maxim guns of the invaders. Armed in large part

1 The Shangani is here a very small stream. It was far away to the north, on the lower course of the same stream, that Major Wilson and his party perished later in the war. 
only with assagais, they were mown down before they could even reach the front of the British line, and their splendid courage made their destruction all the more complete. Had they stuck to the rocky and woody regions they might have made the war a far longer and more troublesome business than it proved to be. No stone marks either battle-field.

From a spot between the two rivers we turned off to the south to visit the prehistoric remains at Dhlodhlo. It was an extremely lonely track, on which we did not meet a human being for some thirty miles. No house, not even a Kafir hut, was to be found, so we bivouacked in the veldt, to the lee of a clump of thorn-bushes. The earlier part of the nights is delightful at this season (October), but it is apt to get cold between 2 and 4 A.M., and as there is usually a south-east wind blowing, the shelter of a bush or an ant-hill is not unwelcome. Whoever enjoys travelling at all cannot but enjoy such a night alone under the stars. One gathers sticks to make the fire, and gets to know which wood burns best. One considers how the scanty supply of water which the waggon carries may be most thriftily used for making the soup, boiling the eggs, and brewing the tea. One listens (we listened in vain) for the roar of a distant lion or the still less melodious voice of the hyena. The brilliance of the stars is such that only the fatigue of the long day-for one must always start by or before sunrise to spare the animals during the sultry noon-and the difficulty of sitting down in a great, bare, flat 
CHAP.

land, where there is not a large stone and seldom even a tree, can drive one into the vehicle to sleep. The meals, consisting of tinned meat and biscuits, with eggs and sometimes a small, lean, and desiccated chicken, are very scanty and very monotonous, but the air is so dry and fresh and bracing that one seems to find meat and drink in it.

Next day we came, at the foot of the Matoppo Hills, to a solitary farm, where we found a bright young Englishman, who, with only one white companion, had established himself in this wilderness and was raising good crops on fields to which he brought water from a neighbouring streamlet. Even the devastation wrought by a blight of locusts had not dispirited him nor diminished his faith in the country. It is not the least of the pleasures of such a journey that one finds so many cheery, hearty, sanguine young fellows scattered about this country, some of them keeping or helping to keep stores, some of them, like our friend here, showing what the soil may be made to do with skill and perseverance, and how homes may be reared upon it. One is always hospitably received; one often finds in the hard-working pioneer or the youth behind the store counter a cultivated and thoughtful mind; one has, perhaps, a glimpse of an attractive personality developing itself under simple yet severe conditions, fitted to bring out the real force of a man. After half an hour's talk you part as if you were parting with an old friend, yet knowing that the same roof is not likely ever to 
cover both of you again. There are, of course, rough and ill-omened explorers and settlers in South Africa, as in other new countries ; but having wandered a good deal, in different countries, on the outer edge of civilization, I was struck by the large proportion of well-mannered and welleducated men whom one came across in this tropical wilderness.

From the young Englishman's farm we turned in among the hills, following the course of the brook, and gently rising till we reached a height from which a superb view to the north unrolled itself. The country was charming, quite unlike the dull brown downs of yesterday. On each side were steep hills, sometimes rocky, sometimes covered thick with wood; between them in the valley a succession of smooth, grassy glades, each circled round by trees. It was rural scenery-scenery in which one could wish to build a cottage and dwell therein, or in which a pastoral drama might be laid. There was nothing to suggest Europe, for the rocks and, still more, the trees were thoroughly African in character, and the air even drier and keener than that of Sicily. But the landscape was one which any lover of Theocritus might have come to love, and some day, when there are large towns in Matabililand, and plenty of Englishmen living in them, the charm of these hills will be appreciated. The valley rises at last to a grassy table-land, where, on a boss of granite rock, stand the ancient walls of Dhlodhlo, which we had come to see. I have already described 
CHAP.

the ruins (see Chapter IX), which are scanty enough, and interesting, not from any beauty they possess, but because we have so few data for guessing at their purpose or the race that built them. The country is now very solitary, and the natives fear to approach the ruins, especially at night, believing them to be haunted. Having spent some hours in examining them, we were just starting when a swarm of locusts passed, the first we had seen. It is a strange sight, beautiful if you can forget the destruction it brings with it. The whole air, to twelve or even eighteen feet above the ground, is filled with the insects, reddish brown in body, with bright, gauzy wings. When the sun's rays catch them it is like the sea sparkling with light. When you see them against a cloud they are like the dense flakes of a driving snow-storm. You feel as if you had never before realized immensity in number. Vast crowds of men gathered at a festival, countless tree-tops rising along the slope of a forest ridge, the chimneys of London houses from the top of St. Paul's, - all are as nothing to the myriads of insects that blot out the sun above and cover the ground beneath and fill the air whichever way one looks. The breeze carries them swiftly past, but they come on in fresh clouds, a host of which there is no end, each of them a harmless creature which you can catch and crush in your hand, but appalling in their power of collective devastation. Yet here in southern Matabililand there had been only a few swarms. We were to see later on, in the eastern 
mountain region, far more terrible evidences of their presence.

From Dhlodhlo we drove to the store on the Shangani River, a distance of twenty miles or more, right across the open veldt, finding our way, with the aid of a native boy, over stony hills and thick shrubs, and even here and there across marshy stream beds, in a way which astonishes the European accustomed to think that roads, or at least beaten tracks, are essential to four-wheeled vehicles. I have driven in an open cart across the central watershed of the Rocky Mountains; but the country there, rough as it is, is like a paved road compared with some parts of the veldt over which the South African guides his team. Once or twice we missed the way in the deepening twilight, and began to prepare ourselves for another night under the stars, with a nearly exhausted food-supply. But at last, just as darkness fell, we reached a native village, and obtained (with difficulty) a native guide for the last few miles of the drive. These miles were lighted by a succession of grass-fires. Such fires are much commoner here than in the prairies of western America, and, happily, much less dangerous, for the grass is usually short and the fire moves slowly. They are sometimes accidental, but more frequently lighted by the natives for the sake of getting a fresh growth of young grass on the part burned and thereby attracting the game. Sometimes the cause is even slighter. The Kafirs are fond of eating the mice and other small inhabitants of the 
veldt, and they fire the grass to frighten these little creatures, and catch them before they can reach their holes, with the further convenience of having them ready roasted. Thus at this season nearly half the land on these downs is charred, and every night one sees the glow of a fire somewhere in the distance. The practice strikes a stranger as a wasteful one, exhausting to the soil, and calculated to stunt the trees, because, though the grass is too short to make the fire strong enough to kill a well-grown tree, it is quite able to injure the younger ones and prevent them from ever reaching their due proportions.

The term "store," which I have just used, requires some explanation. There are, of course, no inns in the country, except in the three or four tiny towns. Outside these, sleeping quarters are to be had only in small native huts, built round a sort of primitive "general shop" which some trader has established to supply the wants of those who live within fifty miles or who pass along the road. The hut is of clay, with a roof of thatch, which makes it cooler than the store with its roof of galvanised iron. White ants are usually at work upon the clay walls, sending down little showers of dust upon the sleeper. Each hut contains two rough wooden frames, across which there is stretched, to make a bed, a piece of coarse linen or ticking. Very prudent people turn back the dirty rug or bit of old blanket which covers the bed, and cast a glance upon the clay floor, to see that no black momba or other renomous snake is already in possession. Such night quarters may 
seem unattractive, but we had many a good night's rest in them. When they are unattainable one camps out.

From the Shangani River to Gwelo the track leads again over a succession of huge, swelling ridges, separated from one another by the valleys of spruits, or streams, now nearly dry, but in the wet season running full and strong. The descent to the spruit, which is often a short, steep pitch and is then called a donga, needs careful driving, and the ascent up the opposite bank is for a heavy waggon a matter of great difficulty. We passed waggons hardly advancing a step, though eight or nine span of oxen were tugging at them, and sometimes saw two or three span detached from another team and attached to the one which had failed, unaided, to mount the slope. No wonder that, when the difficulty of bringing up machinery is so great, impatient mineowners long for the railway.

The first sign that we were close upon Gwelo came from the sight of a number of white men in shirt-sleeves running across a meadow--an unusual sight in South Africa, which presently explained itself as the English inhabitants engaged in a cricket match. Nearly the whole town was either playing or looking on. It was a hot afternoon, but our energetic countrymen were not to be scared by the sun from the pursuit of the national game. They are as much Englishmen in Africa as in England, and, happily for them and for their country, there is no part of the national character 
that is more useful when transplanted than the fondness for active exercise. Gwelo, a cheerful little place, though it stands in a rather bleak country, with a wooded ridge a little way off to the south, interested me as a specimen of the newest kind of settlement. It is not in strictness a mining camp, for there are no reefs in the immediate neighbourhood, but a mining centre, which proposes to live as the local metropolis of a gold-bearing district, a place of supply and seat of local administration. In October, 1895, it had about fifteen houses inhabited by Europeans, and perhaps thirty houses altogether; -but the materials for building other houses were already on the ground, and the usual symptoms of a "boom" were discernible. Comparing it with the many similar "new cities" I had seen in western America, I was much struck with the absence of the most conspicuous features of those cities-the "saloons" and "bars." In California or Montana these establishments, in which the twin deities of gambling and drinking are worshipped with equal devotion, form half the houses of a recent settlement in a mining region. In South Africa, except at and near Johannesburg, one scarcely sees them. Drinking rarely obtrudes itself. What gambling there may be I know not, but at any rate there are no gambling-saloons. Nothing can be more decorous than the aspect of these new African towns, and the conduct of the inhabitants seldom belies the aspect. There is, of course, a free use of alcohol. But there is no 
shooting, such as goes on in American mining towns: crimes of violence of any kind are extremely rare; and the tracks are safe. No one dreams of taking the precautions against "roadagents" (i.e. highwaymen) which are still far from superfluous in the Western States and were far from superfluous in Australia. Trains are not stopped and robbed ; coaches are not "held up." Nothing surprised me more, next to the apparent submissiveness of the native Kafirs, than the order which appeared to prevail among the whites. A little reflection shows that in this northerly part of the country, where travelling is either very slow or very costly and difficult, malefactors would have few chances of escape. But I do not think this is the chief cause of the orderly and law-abiding habits of the people. There have never been any traditions of violence, still less of crime, in South Africa, except as against the natives. The Dutch Boers were steady, solid people, little given to thieving or to killing one another. The English have carried with them their respect for law and authority. In some respects their ethical standard is not that of the mother country. But towards one another and towards those set in authority over them their attitude is generally correct.

The night we spent at Gwelo gave a curious instance of the variability of this climate. The evening had been warm, but about midnight the S.E. wind rose, bringing a thin drizzle of rain, and next morning the cold was that of Boston or Edin- 
CHAP.

burgh in a bitter north-easter. Having fortunately brought warm cloaks and overcoats, we put on all we had and fastened the canvas curtains round the vehicle. Nevertheless, we shivered all day long, the low thick clouds raining at intervals, and the malign blast chilling one's bones. Gwelo, of course, declared that such weather was quite exceptional; but those can have travelled little indeed who have not remarked how often they encounter " exceptional weather," and Gwelo, having existed for eighteen months only, had at best a small experience to fall back upon. The moral for travellers is: "Do not forget to take your furs and your ulsters to tropical South Africa."

Some forty miles beyond Gwelo there is a mountain called Iron Mine Hill, where the Mashonas have for generations been wont to find and work iron. All or nearly all the Kafir tribes do this, but the Mashonas are more skilful at it than were their conquerors the Matabili. Here a track turns off to the south-east to Fort Victoria, the first military post established by the Company in its territories, and for a time the most important. It has fallen into the background lately, partly because the goldreefs have not realized the hopes once formed of them, partly because it suffers from fever after the rains. I went to it because from it one visits the famous ruins at $Z$ imbabwye, the most curious relic of prehistoric antiquity yet discovered in tropical Africa. The journey, one hundred miles from Iron Mine Hill to Victoria, is not an easy one, for there 
are no stores on the way where either provisions or night-quarters can be had, and the track is a bad one, being very little used. The country is well wooded and often pretty, with fantastic, rocky hills rising here and there, but presenting few striking features. Two views, however, dwell in my recollection as characteristic of South Africa. We had slept in a rude hut on the banks of the Shashi River, immediately beneath a rocky kopje, and rose next morning before dawn to continue the journey. Huge rocks piled wildly upon one another towered above the little meadow-rocks covered with lichens of brilliant hues, red, green, and yellow, and glowing under the rays of the level sun. Glossy-leaved bushes nestled in the crevices and covered the mouths of the dens to which the leopards had retired from their nocturnal prowls. One tree stood out against the clear blue on the top of the highest rock. Cliff-swallows darted and twittered about the hollows, while high overhead, in the still morning air, two pairs of large hawks sailed in wide circles round and round the summit of the hill. A few miles farther the track crossed a height from which one could gaze for thirty miles in every direction over a gently rolling country covered with wood, but with broad stretches of pasture interposed, whose grass, bleached to a light yellow, made one think it a mass of cornfields whitening to harvest. Out of these woods and fields rose at intervals what seemed the towers and spires of cities set upon hills. We could have fancied ourselves in central Italy, 
CHAP.

surveying from some eminence like Monte Amiata the ancient towns of Tuscany and Umbria rising on their rocky heights out of chestnut woods and fields of ripening corn. But the city towers were only piles of gray rock, and over the wide horizon there was not a sign of human life-only the silence and loneliness of an untouched wilderness.

From Fort Victoria, where the war of I 893 began by a raid of the young Matabili warriors upon the Mashona tribes, who were living under the protection of the Company, it is seventeen miles to Zimbabwye. The track leads through a pretty country, with alternate stretches of wood and grass, bold hills on either side, and blue peaked mountains in the distance. Crossing a low, bare ridge of granite, one sees nearly a mile away, among thick trees, a piece of gray wall, and when one comes nearer, what seems the top of a tower just peering over the edge of the wall. This is Zimbabwye-a wall of loose but well-trimmed and neatly fitted pieces of granite surrounding an elliptical inclosure; within this inclosure other half-ruined walls over-grown by shrubs and trees, and a strange solid tower or pillar thirty feet high, built, without mortar, of similar pieces of trimmed granite. ${ }^{1}$ This is all that there is to see. One paces to and fro within the inclosure and measures the width and length of the passages between the walls. One climbs the great inclosing wall at a point where part of it has been broken down, and walks along the broad top, picking

1 These ruins have been described in Chapter IX. 
one's way over the stems of climbing shrubs, which thrust themselves across the wall from beneath or grow rooted in itscrevices. One looks and looks again, and wonders. But there is nothing to show whether this gray wall is three centuries or thirty centuries old. There is no architectural style, no decoration even, except a rudely simple pattern on the outside of the wall which faces the east; so there is nothing by which one can connect this temple, if it is a temple, with the buildings of any known race or country. In this mystery lies the charm of the spot-in this and in the remoteness and silence of a country which seems to have been always as it is to-day. One mark of modern man, and one only, is to be seen. In the middle of the valley, some three hundred yards from the great building, Mr. Cecil Rhodes has erected a monument to Major Wilson and the thirty-seven troopers who fell with him on the Lower Shangani River in December, I893, fighting gallantly to the last against an overwhelming force of Matabili. The monument stands on an eminence surrounded by the broken wall of some ancient stronghold. It has been wisely placed far enough from the great ruin, not to form an incongruous element in the view of the latter, and it was an imaginative thought to commemorate, at a spot in this new land which bears witness to a race of prehistoric conquerors, the most striking incident in the history of the latest conquest.

We climbed the rocky height, where the skilfully constructed walls of the ancient fort show that those 
CHAP.

who built Zimbabwye lived in fear of enemies. We sat beside the spring, a clear though not copious spring, which rises a little to the south of the great building from a fissure in the rock. Fountains so clear are rare in this country, and the existence of this one probably determined the site of the great building itself. It flows into a small pool, and is then lost, being too small to form a rivulet. No trace of man's hand is seen round it or on the margin of the pool, but those who worshipped in the temple of Zimbabwye doubtless worshipped this fountain also, for that is one of the oldest and most widely diffused forms of worship in the world. Restless nature will some day overthrow the walls of the temple, which she is piercing with the roots of shrubs and entwining with the shoots of climbing wild vines, and then only the fountain will be left.

From Fort Victoria to Fort Salisbury it is nearly two hundred miles, the country generally level, though studded, like parts of southern India, with isolated rocky hills, whose crags of granite or gneiss break under the sun and rain into strange and fantastic shapes. A people sufficiently advanced to erect fortifications might have made for themselves impregnable strongholds out of the tops of these kopjes. The timid Makalakas have in many places planted their huts in the midst of the huge detached masses into which the kopjes are cleft; but they have not known how to make their villages defensible, and have been content with piling up a fewloose stones to close some narrow passage between the rocks, or 
surrounding their huts with a rough fence of thornbushes. We found one deserted village where upon each loose block there had been placed a rude srection of clay, covered at the top, and apparently intended for the storing of grain. Thus raised from the ground it was safer from wild beasts and from rain. All the dwelling huts but two had been burned. We entered these, and found the walls covered with the rudest possible representations of men and animals, drawn with charcoal, more coarsely than an average child of ten would draw, and far inferior in spirit to the figures which the Lapps of Norway will draw on a reindeer horn spoon, or the Red Indians of Dakota upon a calico cloak. Whether the village had perished by an accidental fire, or whether its inhabitants, relieved from that terror of the Matabili which drove them to hide amongst the rocks, had abandoned it for some spot in the plain below, there was no one to. tell us. One curious trace of insecurity remained in a dry and light tree-trunk, which had been left standing against the side of a flat-topped rock some thirty feet high, with the lowest dozen feet too steep to be climbed. It had evidently served as a sort of ladder. By it the upper part of the rock might be gained, and when it had been pulled up, approach was cut off and the fugitives on the flat top might be safe, while the Matabili were plundering their stores of grain and killing their friends beneath.

All this eastern side of the country was frequently raided by the Matabili, whose home lay farther 
west towards Bulawayo. The Makalakas could offer no resistance, not only because they were poor fighters, but also because they were without cohesion. The clans were small and obeyed no common overlord. Most of the villages lived quite unconnected with one another, yielding obedience, often a doubtful obedience, to their own chief, but caring nothing for any other village. Among savages the ascendency of a comparatively numerous tribe which is drilled to fight, and which renders inplicit obedience to its chief, is swift and complete. The Matabili when they entered this country had probably only ten or twelve thousand fighting men ; but they conquered it without the slightest difficulty, for the inhabitants, though far more numerous, were divided into small communities, and did not attempt to offer any collective resistance. Then for more than half a century slaughter and pillage reigned over a tract of some ninety thousand square miles. Much of this tract, especially the eastern part, which we call Mashonaland, was well peopled by tribes who lived quietly, had plenty of cattle, tilled the soil, and continued to dig a little gold, as their forefathers had done for centuries. They were now mercilessly raided by the Matabili all the way from Lake Ngami on the west to the edge of the great plateau on the east, till large districts were depopulated and left desolate, the grown men having been all killed or chased away, the children either killed, or made slaves of, or taken as recruits into the Matabili army. Constant war and the 
sanguinary government of Lo Bengula reduced the number of the true Matabili, so that such recruiting became a necessity. Their successes filled the Matabili with an overweening confidence in their power. Through all South Africa they despised every native tribe, except that martial one which was ruled by Gungunhana on the eastern frontier of Mashonaland, and despised even the white men, thinking them but a handful. The indunas, who had visited London in I89I, endeavoured to warn them of the resources of the whites, and Lo Bengula himself was opposed to war. But the young braves, who, like Cetewayo's Zulus, desired to " wash their spears," overbore the reluctance of the monarch, only to perish in the war of 1893 .

Towards Fort Salisbury the country rises and grows prettier as it shows signs of a more copious rainfall. New flowers appear, and the grass is greener. About twelve miles before the town is reached one crosses a considerable stream with a long, deep, clear pool among rocks, and is told of the misadventure of an English doctor who, after a hasty plunge into the pool, was drying himself on a flat stone just above the water when a crocodile suddenly raised its hideous snout, seized his leg in its jaws, and dragged him down. Fortunately his companions were close at hand and succeeded after a struggle in forcing the beast to drop its prey.

The town itself is built at the foot of a low, wooded hill, on the top of which stood the original fort, hastily constructed of loose stones in 1890, 
CHAP.

and occupied in serious earnest for defence during the Matabili war. It spreads over a wide space of ground, with houses scattered here and there, and has become, since the draining of the marshy land on the banks of a streamlet which runs through it, free from malaria and quite healthy. Though the sun heat was great in the end of October (for one is only eighteen degrees from the equator), the air was so fresh and dry that I could walk for miles in the full blaze of noon, and the nights were too cool to sit out on the stoep (the wooden veranda which one finds at the front of every South African house) without an overcoat. Just round the town the country is open and grassy, but the horizon in every direction is closed by woods. The views are far prettier than those from Bulawayo, and the position of the town makes it a better centre for the administration as well as the commerce of the Company's territories. It is only two hundred and twenty miles from the Zambesi at Tete, and only three hundred and seventy from the port of Beira. The Company did well to encourage the growth of Bulawayo immedidiately after the conquest of 1893 , because it was necessary to explore and to establish order in the newest parts of its territory. But in the long run, and especially when the regions north of the Zambesi begin to be practically occupied, Bulawayo, standing in a corner of the country, will have to yield to the more imperial site of Fort Salisbury. The district which lies round the latter town is better watered than western Matabililand, and the 
soil richer both for pasture and for tillage. The rainfall for the year ending April, I890, reached fifty-three inches, and the average is about forty.

Fort Salisbury is three years older than Bulawayo, and therefore much more advanced. It has even several churches. There is a colony of East Indians, who grow vegetables and get very high prices for them; and a considerable trade is done in supplying the needs of the mining districts to the north and west. Many gold-reefs lie out in those directions, and great hopes are entertained of their future, though at the time of my visit people were much busier in floating new companies to develop the mines than in taking steps for their actual development. Some very pretty country residences, in the style of Indian bungalows, have been built on the skirts of the woods a mile or two from the town; and street-lamps now light people to their homes along paths where four years ago lions were still encountered. The last lion recoiling in dismay from the first street lamp would be a good subject for a picture to illustrate the progress of Mashonaland. 


\section{CHAPTER XVI}

FROM FORT SALISBURY TO THE SEA-MANICALAND

AND THE PORTUGUESE TERRITORIES

In Africa, moisture is everything. It makes the difference between fertility and barrenness ; it makes the difference between a cheerful and a melancholy landscape. As one travels north-eastward from Palapshwye to Bulawayo, and from Bulawayo to Fort Salisbury, one passes by degrees from an arid and almost rainless land to a land of showers and flowing waters. In Bechuanaland there are, except for three months in the year, no streams at all. In Matabililand one begins to find perennial brooks. In Mashonaland there are at last rivers, sometimes with rocky banks and clear, deep pools, which (like that just mentioned) tempt one to bathe and risk the terrible snap of a crocodile's jaws. Thus eastern Mashonaland is far more attractive than the countries which I have described in the last two chapters. It has beautiful and even striking scenery. The soil, where the granitic rocks do not come too near the surface, is usually fertile, and cultivation is easier than in the regions to the 
south-west, because the rains are more copious. There are many places round Fort Salisbury and on the way thence to Mtali and Massikessi where a man might willingly settle down to spend his days, so genial and so full of beauty is the nature around him. And as the land is high, it is also healthy. Except in a few of the valley bottoms, fever need not be feared, even after the rains.

From Fort Salisbury to the Indian Ocean at Beira it is a journey of three hundred and seventy miles, of which the first one hundred and fifty-five are in British, the rest in Portuguese, territory. When the railway, which now (May, I897) runs inland for one hundred and fifty-eight miles from Beira, has been completed to Fort Salisbury, this distance, which at present requires at least eight days travel, will become a trifle. But those who will then hurry through this picturesque region behind the locomotive will lose much of the charm which the journey, by far the most attractive part of a South African tour, now has for the lover of nature.

For the first forty miles south-eastward from Fort Salisbury the track runs through a wooded country, diversified by broad stretches of pasture. Here and there we found a European farm, marked in the distance by the waving tops of the gumtrees, with the low wooden house festooned by the brilliant mauve blossoms of the climbing bougainvillea, and the garden inclosed by hedges of grenadilla, whose fruit is much eaten in South Africa. Vegetables raised on these farms fetch enormous 
CHAP.

prices in the town, so that a man who understands the business may count on making more by this than he will do by "prospecting" for gold mines or even by floating companies. We found the grass generally fresh and green, for some showers had fallen, and the trees, though still small, were in new leaf with exquisite tints of red. Now and then, through gaps between the nearer hills, there are glimpses of dim blue mountains. As one gets farther to the southeast the hills are higher, and on either side there rise fantastic kopjes of granite. Their tops are cleft and riven by deep fissures, and huge detached blocks are strewn about at their base, or perched like gigantic tables upon the tops of pillars of rock, poised so finely that one fancies a blast of wind might overthrow them. These "perched blocks," however, have not, like the blocs perchés of western Europe, been left by ancient glaciers or icebergs, for it seems still doubtful whether there has been a glacial period in South Africa, and neither here nor in the mountains of Basutoland could I discover traces of ancient moraines. They are due to the natural decomposition of the rock on the spot. The alternate heat of the day and cold of the night-a cold which is often great, owing to the radiation into a cloudless sky-split the masses by alternate expansion and contraction, make great flakes peel off them like the coats of an onion, and give them these singularly picturesque shapes. All this part of the country is as eminently fit for a landscape-painter as Bechuanaland and the more level 
parts of Matabililand are unfit, seeing that here one has foregrounds as well as backgrounds, and the colours are as rich as the forms are varied. For I must add that in this region, instead of the monotonous thorny acacias of the western regions, there is much variety in the trees; no tropical luxuriance,-the air is still too dry for that,-but many graceful outlines and a great diversity of foliage. Besides, the wood has a way of disposing itself with wonderful grace. There is none of the monotony either of pine forests, like those of northern and eastern Europe, or of such forests of deciduous trees as one sees in Michigan and the Alleghanies, but rather what in England we call "park-like scenery," though why nature should be supposed to do best when she imitates art, I will not attempt to inquire. There are belts of wood inclosing secluded lawns, and groups of trees dotted over a stretch of rolling meadow, pretty little bits of detail which enhance the charm of the ample sweeps of view that rise and roll to the far-off blue horizon.

Beyond Marandella's-the word sounds Italian, but is really the Anglicized form of the name of a native chief-the country becomes still more open, and solitary peaks of gneiss begin to stand up, their sides of bare, smooth gray rock sometimes too steep to be climbed. Below and between them are broad stretches of pasture, with here and there, on the banks of the streams, pieces of land which seem eminently fit for tillage. On one such piece-it is 
called Lawrencedale-we found that two young Englishmen had brought some forty acres into cultivation, and admired the crops of vegetables they were raising partly by irrigation, partly in reliance on the rains. Almost anything will grow, but garden-stuff pays best, because there is in and round Fort Salisbury a market clamorous for it. The great risk is that of a descent of locusts, for these pests may in a few hours strip the ground clean of all that covers it. However, our young farmers had good hopes of scaring off the swarms, and if they could do so their profits would be large and certain. A few hours more through driving showers, which made the weird landscape of scattered peaks even more solemn, brought us to the halting-place on Lezapi River, a pretty spot high above the stream, where the store which supplies the neighbourhood with the necessaries of life has blossomed into a sort of hotel, with a good many sleeping-huts round it. One finds these stores at intervals of about twenty or thirty miles; and they, with an occasional farm like that of Lawrencedale, represent the extremely small European population, which averages less than one to a dozen square miles, even reckoning in the missionaries that are scattered here and there.

From Lezapi I made an excursion to a curious native building lying some six miles to the east, which Mr. Selous had advised me to see. The heat of the weather made it necessary to start very early, so I was awakened while it was still dark. But when I stood ready to be off just before sunrise, the Kafir 
boy, a servant of the store, who was to have guided me, was not to be found. No search could discover him. He had apparently disliked the errand, perhaps had some superstitious fear of the spot he was to lead me to, and had vanished, quite unmoved by the prospect of his employer's displeasure and of the sum he was to receive. The incident was characteristic of these natives. They are curiously wayward. They are influenced by motives they cannot be induced to disclose, and the motives which most affect a European sometimes fail altogether to tell upon them. With great difficulty I succeeded in finding another native boy who promised to show me the way, and followed him off through the wood and over the pastures, unable to speak a word to him, and of course understanding not a word of the voluble bursts of talk with which he every now and then favoured me. It was a lovely morning, the sky of a soft and creamy blue, dewdrops sparkling on the tall stalks of grass, the rays of the low sun striking between the tree-tops in the thick wood that clothed the opposite hill, while here and there faint blue smoke-wreaths rose from some Kafir hut hidden among the brushwood. We passed a large village, and just beyond it overtook three Kafirs all talking briskly, as is their wont, one of them carrying a gun and apparently going after game. A good many natives have firearms, but acts of violence seem to be extremely rare. Then passing under some rocky heights, we saw, after an hour and a half's fast walking, the group of huts where the 
Company's native commissioner, whom I was going to find, had fixed his station. Some Kafirs were at work on their mealie-plots, and one of them, dropping his mattock, rushed across and insisted on shaking hands with me, saying "Moragos," which is said to be a mixture of Dutch and Kafir meaning "Good morning, sir." The commissioner was living alone among the natives, and declared himself quite at ease as to their behaviour. One chief dwelling near had been restive, but submitted when he was treated with firmness; and the natives generallyso he told me-seem rather to welcome the intervention of a white man to compose their disputes. They are, he added, prone to break their promises, except in one case. If an object, even if of small value, has been delivered to them as a token of the engagement made, they feel bound by the engagement so long as they keep this object, and when it is formally demanded back they will restore it unharmed. The fact is curious, and throws light on some of the features of primitive legal custom in Europe.

The commissioner took me to the two pieces of old building-one can hardly call them ruins-which I had come to see. One (called Chipadzi's) has been already mentioned (see p. 89 , ante). It is a bit of ancient wall of blocks of trimmed granite, neatly set without mortar, and evidently meant to defend the most accessible side of a rocky kopje, which in some distant age had been a stronghold. It has all the appearance of having been constructed by the same race that built the walls of Dhlodhlo 
(see p. 84) and Zimbabwye (see p. 90) (though the work is not so neat), and is called by the natives a Zimbabwye. Behind it, in the centre of the kopje, is a rude low wall of rough stones inclosing three huts, only one of which remains roofed. Under this one is the grave of a famous chief called Makoni,the name is rather an official than a personal one, and his personal name was Chipadzi,- the uncle of the present Makoni, who is the leading chief of this district. ${ }^{1}$ On the grave there stands a large earthenware pot, which used to be regularly filled with native beer when, once a year, about the anniversary of this old Makoni's death, his sons and other descendants came to venerate and propitiate his ghost. Five years ago, when the white men came into the country, the ceremony was disused, and the poor ghost is now left without honour and nutriment. The pot is broken, and another pot, which stood in an adjoining hut and was used by the worshippers, has disappeared. The place, however, retains its awesome character, and a native boy who was with us would not enter it. The sight brought vividly to mind the similar spirit-worship which went on among the Romans and which goes on to-day in China; but I could not ascertain for how many generations back an ancestral ghost receives these attentions - a point which has remained obscure in the case of Roman ghosts also.

1 This chief was the restive chief mentioned on the last preceding page. He joined in the rising of 1896 , and was, I believe, taken prisoner and shot. 
The other curiosity is much more modern. It is a deserted native village called Tchitiketi ("the walled town "), which has been rudely fortified with three concentric lines of defence, in a way not common among the Kafirs. The huts, which have now totally disappeared, stood on one side of a rocky eminence, and were surrounded by a sort of ditch ten feet deep, within which was a row of trees planted closely together, with the intervals probably originally filled by a stockade. Some of these trees do not grow wild in this part of the country, and have apparently been planted from shoots brought from the Portuguese territories. Within this outmost line there was a second row of trees and a rough stone wall, forming an inner defence. Still farther in one finds a kind of citadel, formed partly by the rocks of the kopje, partly by a wall of rough stones, ten feet high and seven to eight feet thick, plastered with mud, which holds the stones together like mortar. This wall is pierced by small apertures, which apparently served as loopholes for arrows, and there is a sort of narrow gate through it, only four and a half feet high, covered by a slab of stone. Within the citadel, several chiefs are buried in crevices of the rock, which have been walled up and there are still visible the remains of the huts wherein, upon a wicker stand, were placed the pots that held the beer provided for their ghosts. Having ceased to be a royal residence or a fortress, the spot remains, like the Escurial, a place of royal sepulture. The natives remember the names of the 
dead chiefs, but little else, and cannot tell one when the fortress was built nor why it was forsaken. Everything is so rude that one must suppose the use of loopholes to have been learned from the Portuguese, who apparently came from time to time into these regions; and the rudeness confirms the theory that the buildings at the Great Zimbabwye were not the work of any of the present Bantu tribes, but of some less barbarous race.

It is not easy to find one's way alone over the country in these parts, where no Kafir speaks English or even Dutch, and where the network of native foot-paths crossing one another soon confuses recollection. However, having a distant mountainpeak to steer my course by, I succeeded in making my way back alone, and was pleased to find that, though the sun was now high in heaven and I had neither a sun-helmet nor a white umbrella, its rays did me no harm. A stranger, however, can take liberties with the sun which residents hold it safer not to take. Europeans in these countries walk as little as they can, especially in the heat of the day. They would ride, were horses attainable, but the horse-sickness makes it extremely difficult to find or to retain a good animal. All travelling for any distance is of course done in a waggon or (where one can be had) in a Cape cart.

From the Lezapi River onward the scenery grows more striking as one passes immediately beneath some of the tall towers of rock which we had previously admired from a distance. They remind one, 
in their generally gray hue and the extreme boldness of their lines, of some of the gneissose pinnacles of Norway, such as those above Naerodal, on the Sogne Fiord. One of them, to which the English have given the name of the Sugar Loaf, soars in a face of smooth sheer rock nearly Iooo feet above the track, the lichens that cover it showing a wealth of rich colours, greens and yellows varied here and there by long streaks of black rain-drip. Behind this summit to the north-east, eight to twelve miles away, rose a long range of sharp, jagged peaks, perfectly bare, and showing by their finecut lines the hardness of their rock. They were not lofty, at most 2000 feet above the level of the plateau, which is here from 4000 to 5000 feet above sea-level. But the nobility of their forms, and their clear parched sternness as they stood in the intense sunshine, made them fill and satisfy the eye beyond what one would have expected from their height. That severe and even forbidding quality which is perceptible in the aspect of the South African mountains, as it is in those of some other hot countries, seems to be due, in some degree at least, to the sense of their aridity and bareness. One feels no longing to climb them, as one would long to climb a picturesque mountain in Europe, because one knows that upon their scorching sides there is no verdure and that no spring breaks from beneath their crags. Beautiful as they are, they are repellant; they invite no familiarity; they speak of the hardness, the grimness, the silent 
aloofness of nature. It is only when they form the distant background of a view, and especially when the waning light of evening clothes their stern forms with tender hues, that they become elements of pure delight in the landscape.

Some fifteen miles east of this range we came upon a natural object we had given up hoping to see in South Africa, a country where the element necessary to it is so markedly deficient. This was the waterfall on the Oudzi River, one of the tributaries of the great Sabi River, which falls into the Indian Ocean. The Oudzi is not very large in the dry season, nor so full as the Garry at Killiecrankie or the stream which flows through the Yosemite Valley. But even this represents a considerable volume of water for tropical East Africa; and the rapid-it is really rather a rapid than a cascademust be a grand sight after heavy rain, as it is a picturesque sight even in October. The stream rushes over a ridge of very hard granite rock, intersected by veins of finer-grained granite and of greenstone. It has cut for itself several deep channels in the rock, and has scooped out many hollows, not, as usually, circular, but elliptical in their shape, polished smooth, like the little pockets or basins which loose stones polish smooth as they are driven round and round by the current in the rocky bed of a Scotch torrent. The brightness of the clear green water and the softness of the surrounding woods, clothing each side of the long valley down which the eye pursues the stream till 
the vista is closed by distant mountains, make these falls one of the most novel and charming bits of scenery even in this romantic land. Another pleasant surprise was in store for us before we reached Mtali. We had seen from some way off a mass of brilliant crimson on a steep hillside. Coming close under, we saw it to be a wood whose trees were covered with fresh leaves. The locusts had eaten off all the first leaves three weeks before, and this was the second crop. Such a wealth of intense yet delicate reds of all hues, pink, crimson, and scarlet, sometimes passing into a flushed green, sometimes into an umber brown, I have never seen, not even in the autumn woods of North America, where, as on the mountain that overhangs Montreal, the forest is aflame with the glow of the maples. The spring, if one may give that name to the season of the first summer rains, is for South Africa the time of colours, as is the autumn in our temperate climes.

Mtali-it is often written "Umtali" to express that vague half-vowel which comes at the beginning of so many words in the Bantu languages-is a pretty little settlement in a valley whose sheltered position would make it oppressive but for the strong easterly breeze which blows nearly every day during the hot weather. There is plenty of good water in the hills all round, and the higher slopes are green with fresh grass. The town, like other towns in these regions, is constructed of corrugated iron,- - for wood is scarce and dear,-with a few brick-walled 
houses and a fringe of native huts, while the outskirts are deformed by a thick deposit of empty tins of preserved meat and petroleum. All the roofs are of iron, and a prudent builder puts iron also into the foundation of the walls beneath the brick, in order to circumvent the white ants. These insects are one of the four plagues of South Central Africa. (The other three are locusts, horse-sickness, and fever; some add a fifth-the speculators in mining shares.) They destroy every scrap of organic matter they can reach, and will even eat their way through brick to reach wood or any other vegetable matter. Nothing but metal stops them. They work in the dark, constructing a kind of tunnel or gallery if they have to pass along an open space, as, for instance, to reach books upon a shelf. (I was taken to see the public library at Mtali, and found they had destroyed nearly half of it.) They are less than half an inch long, of a dull grayish white, the queen, or female, about three times as large as the others. Her quarters are in a sort of nest deep in the ground, and if this nest can be found and destroyed the plague will be stayed, for a time at least. There are several other kinds of ants. The small red ant gets among one's provisions and devours the cold chicken. We spent weary hours in trying to get them out of our food-boxes, being unable to fall in with the local view that they ought to be eaten with the meat they swarm over, as a sort of relish to it. There is also the large reddish-black ant, which bites fiercely, but is regarded with favour because it 
CHAP.

kills the white ants when it can get at them. But the white ant is by far the most pernicious kind, and a real curse to the country.

At the end of 1896, when the construction of the Beira railway from Chimoyo to Fort Salisbury began to be energetically prosecuted, it was found that to take the line past Mtali would involve a detour of some miles and a heavy gradient in crossing a ridge at the Christmas Pass. Mr. Rhodes promptly determined, instead of bringing the railway to the town, to bring the town to the railway. Liberal compensation was accordingly paid to all those who had built houses at old Mtali, and new Mtali is now ( 1897 ) rising on a carefully selected site seven miles away.

In 1895 there were about one hundred Europeans in the town of Mtali, all, except the Company's officials and the storekeepers, engaged in prospecting for or beginning to work gold-mines; for this is the centre of one of the first-explored gold districts, and sanguine hopes have been entertained of its reefs. We drove out to see some of the most promising in the Penha Longa Valley, six miles to the eastward. Here three sets of galleries have been cut, and the extraction of the metal was said to be ready to begin if the machinery could be brought up from the coast. As to the value and prospects of the reefs, over which I was most courteously shown by the gentlemen directing the operations, I could of course form no opinion. They are quartz-reefs, occurring in talcose and chloritic schistose rocks, and some of 
them maintain their direction for many miles. There is no better place than this valley ${ }^{1}$ for examining the ancient gold-workings, for here they are of great size. Huge masses of alluvial soil in the bottom of the valley had evidently been worked over, and indeed a few labourers are still employed upon these. But there had also been extensive open cuttings all along the principal reefs, the traces of which are visible in the deep trenches following the line of the reefs up and down the slopes of the hills, and in the masses of rubbish thrown out beside them. Some of these cuttings are evidently recent, for the sides are in places steep and even abrupt, which they would not be if during many years the rains had been washing the earth down into the trenches. Moreover, iron implements have been found at the bottom, of modern shapes and very little oxidised. Probably, therefore, while some of these workings may be of great antiquity, others are quite recent-perhaps less than a century old. Such workings occur in many places over Mashonaland and Matabililand. They are always open ; that is to say, the reef was worked down from the surface, not along a tunnel-a fact which has made people think that they were carried on by natives only; and they almost always stop when water is reached, as though the miners had known nothing of pumps. Tradition has nothing to say as to the workings; but we know that during

1 It was here only, on the banks of a stream, that I observed the extremely handsome arboraceous St.-John's-wort (Hypericum Schimperi), mentioned in Chapter IV. 
the sixteenth and seventeenth centuries a good deal of gold was brought down to the Portuguese coast stations; and when the Mashonaland pioneers came in I 890 , there were a few Portuguese trying to get the metal out of the alluvial deposits along the stream banks. The reefs, which are now being followed by level shafts or galleries driven into the sides of the hills, are (in most cases at least) the same as those which the old miners attacked from above.

North of Penha Longa lies an attractive bit of country, near a place called Inyanga, which, unfortunately, we had not time to visit. It is a sort of table-land about thirty miles long by fifteen wide, from 6000 to 7000 feet above sea-level, with the highest summits reaching 8000 feet; and in respect of its height enjoys not only a keen and bracing air, but a copious rainfall, which makes it a specially good grazing-country. It will probably one day become not only the choicest ranchingground of East Central Africa, but also a health resort from the surrounding regions. At present it is quite empty, the land having been, as I was told, bought up by several syndicates, who are holding it in hope of a rise in prices. Here are the remarkable stone-cased pits, referred to in Chapter IX.; and here there are also numerous ancient artificial water-courses for irrigating the soil, which were probably constructed by some race of immigrants accustomed to artificial irrigation in their own country, for it would hardly have occurred to 
natives to construct such works here, where the rainfall is sufficient for the needs of tillage. Still farther to the north is a less elevated region, remarkable for the traces it bears of having been at one time densely populated. Tillage was so extensive that the very hillsides were built up into terraces to be planted with crops. To-day there are hardly any inhabitants, for a good many years ago Mzila, the father of Gungunhana, chief of a fierce and powerful tribe which lives on the lower course of the Sabi River, raided all this country, and in successive invasions killed off or chased away the whole population. Such wholesale slaughter and devastation is no uncommon thing in the annals of South Africa. Tshaka, the uncle of Cetewayo, annihilated the inhabitants over immense tracts round Zululand. And in comparison with such bloodthirsty methods the Assyrian plan of deporting conquered populations from their homes to some distant land may have seemed, and indeed may have been, a substantial step in human progress. However, just when Tshaka was massacring his Kafir neighbours, the Turks were massacring the Christians of Chios, and at the time of our visit, in October, I895, AbdulHamid II. was beginning his massacres in Asia Minor; so perhaps the less said about progress the better.

The track from Mtali to the sea crosses a high ridge at a point called the Christmas Pass, and descends into Portuguese territory through some 
very noble and varied mountain scenery. ${ }^{1}$ It reminded us sometimes of the Italian slopes of the eastern Alps, sometimes of the best parts of the Perthshire Highlands, though of course it was rather in the forms of hill and valley than in the trees that clothed their slopes that this resemblance lay. The first Portuguese settlement is at a place called Macequece, or Massikessi, where the pioneers of the British South Africa Company conducted in I89 I a little war on their own account with the Portuguese, whose superior forces they routed. The Portuguese claimed all this inland region on the Hinterland principle, in respect of their ownership of the coast, while the British pioneers relied on the fact that their adversaries had never established a really effective occupation. The dispute was carried by the Portuguese Mozambique Company into the English courts of law, ${ }^{2}$ and was ultimately adjusted diplomatically by an agreement between the British and Portuguese governments, signed June II, I89I. The delimitation of the frontiers was not fully completed in this region till 1896, but Massikessi was by the treaty of 189 I left to Portugal. After Massikessi the mountains recede, and wide plains begin to open to the east and south. As the country sinks, the temperature rises and the air grows heavier and less keen. The ground is covered with wood, and in the woods

1 It is in the midst of this scenery that new Mtali is being now built (1897).

2 Law Reports for 1893 , A. C., p. 602. 
along the streams a few palms and bamboos and other tropical forms of vegetation begin to appear. ${ }^{1}$ But we found the woods in many places stripped bare. Terrible swarms of locusts had passed, leaving a track of dismal bareness. It had been a dry year, too, and even what grass the locusts had spared was thin and withered. Thus for want of food the cattle had perished. All along the road from Mtali we saw oxen lying dead, often by some pool in a brook, to which they had staggered to drink, and where they lay down to die. We encountered few waggons, and those few were almost all standing with the team unyoked, some of their beasts dead or sickly, some, too weak to draw the load farther, obliged to stand idly where they had halted till the animals should regain strength, or fresh oxen be procured. This is what a visitation of locusts means, and this is how the progress of the country is retarded by the stoppage of the only means of transport. No wonder that over all the districts we had traversed, from Fort Salisbury southward, the cry had been for the completion of the railway. It is, indeed, the first need of these territories; and those who have seen what the want of it has meant are rejoiced to think that by the end of 1897 it will

1 It is in these woods that the honey bird is found, whereof the tale is told that it hunts about for the nests of wild bees in the hollows of trees, and when it has found one, flies close to a man so as to attract his notice, then flutters in front of him to the nest, and waits for him to take the honey out of the hollow (which it cannot itself reach) expecting and receiving a share of the spoil. 
probably have reached $\mathrm{Mtali}$, and in a year or two more have been carried on to Fort Salisbury. As far as Massikessi there will be no great difficulty, for, though the country is hilly, the gradients need seldom be severe. Thence northward across the mountains for some distance skilful engineering will be required. But in South Africa, as in western America, railways are built in a rough-and-ready way, which recks little of obstacles that would prove very costly in Europe.

We reached the present terminus of the railway at Chimoyo after two days' long and fatiguing travel from Mtali, including an upset of our vehicle in descending a steep donga to the bed of a streamlet -an upset which might easily have proved serious, but gave us nothing worse than a few bruises. The custom being to start a train in the afternoon and run it through the night, - as yet all trains are practically special, - we had plenty of time to look round the place, and fortunately found a comfortable store and a most genial Scottish landlord from Banffshire. There was, however, nothing to see, not even Portuguese local colour; for though Chimoyo is well within the Portuguese frontier, the village is purely English, living by the transport service which makes the end of the railway its starting-point for the territories of the Company. Having nothing else to do, I climbed through the sultry noon to the top of the nearest kopje, a steep granite hill which, as I was afterwards told, is a favourite "house of call" for lions. No forest monarch, however, pre- 
sented himself to welcome me, and I was left to enjoy the view alone. It was striking. Guarding the western horizon rose the long chain of mountains from which we had emerged, stretching in a huge arc from south-east to north, with some bold outlying peaks flung forward from the main mass, all by their sharp, stern outlines, in which similar forms were constantly repeated, showing that they were built of the same hard crystalline rocks. Beneath, the country spread out in a vast, wooded plain, green or brown, according as the wood was denser in one part and sparser in another. It was still low wood, with no sense of tropical luxuriance about it, and the ground still dry, with not a glimpse of water anywhere. Here and there out of this sea of forest rose isolated heights whose abrupt craggy tops glistened in the sunlight. To the east the plain fell slowly away to an immensely distant horizon, where lay the deadly flats that border the Indian Ocean. Except where the iron roofs of the huts at Chimoyo shone, there was not a sign of human dwelling or human labour through this great wild country, lying still and monotonous under a cloudless sky. It has been a wilderness from the beginning of the world until now, traversed, no doubt, many centuries ago by the gold-seekers whose favourite track went up from the coast past Great Zimbabwye into what is now Matabililand, traversed again occasionally in later times by Portuguese traders, but in no wise altered during these thousands of years from its original aspect. 
CHAP.

Now at last its turn has come. A new race of goldseekers have built a railway, and along the railway, wherever there are not swamps to breed fever, the land will be taken for farms, and the woods will be cut down, and the wild beasts will slink away, and trading-posts will grow into villages, and the journey from Beira to Bulawayo will become as easy and familiar as is to-day the journey from Chicago to San Francisco, through a country which a century ago was as little known as this African wilderness.

The railway from Chimoyo to the sea has one of the narrowest gauges in the world (two feet), and its tiny locomotives and cars have almost a toy air. It has, however, rendered two immense services to this region: it has abridged the toilsome and costly ox transport of goods from Beira to the edge of the high country-a transport whose difficulty lay not merely in the badness of the track through ground almost impassable during and after the rains, but also in the prevalence of the tsetse-fly, whose bite is fatal to cattle; and it carries travellers in a few hours across one of the most unhealthy regions in the world, most of which is infested by fevers in and after the wet season, and the lower parts of which are so malarious that few who spend three nights in them, even in the dry season, escape an attack. The banks of the rivers and other damper spots will continue to breed this curse of maritime Africa. Although things will doubtless improve when the country grows more settled, and the marshes have 
been drained, and the long grass has been eaten down by cattle; for when the tsetse-fly ceases to be dangerous cattle may come in. It appears that the fly kills cattle not by anything poisonous in its bite, but because it communicates to them a minute parasite which lives in the blood of some kinds of game, and which is more pernicious to cattle than it is to the game. Accordingly, when the game vanishes, the fly either vanishes also or becomes comparatively harmless. Already places once infested by it have by the disappearance of the game become available for ranching. Recent researches seem to have shown that malarial fevers in man are also due to an animal parasite: and this discovery is thought to damp the hope, which I remember to have heard Mr. Darwin express, that the fever-stricken regions of the tropics might become safe by ascertaining what the fever microbe is and securing men against it by inoculation. The railway was made entirely by native labour gathered from the surrounding regions, and the contractors told me they had less difficulty with the Kafirs than they expected. It paid, however, a heavy toll in European life. Not one of the engineers and foremen escaped fever, and many died. The risk for those employed on the line is of course now much slighter, because the worst spots are known and there are now houses to sleep in. There is talk of widening the line, whose small trucks would be unequal to a heavy traffic. Considering the difficulties overcome, especially in the swampy lands towards the coast, large parts of 
which are flooded in January and February, it reflects great credit on those who constructed it.

Shortly after leaving Chimoyo the train ran through a swarm of locusts miles long. It was a beautiful sight. The creatures flash like red snowflakes in the sun; the air glitters with their gauzy wings. But it is also terrible. An earthquake or a volcanic eruption is hardly more destructive and hardly more irresistible. The swarms may be combated when the insect walks along the ground, for then trenches may be dug into which the advancing host falls. But when it flies nothing can stop it. It is noteworthy that for eighteen years prior to the arrival of the British pioneers in 1890 there had been no great swarms. Since that year there have been several; so the Kafir thinks that it is the white man's coming that has provoked the powers of evil to send the plague.

We ran down the one hundred and eighteen miles from Chimoyo to Fontesvilla during the afternoon and night, halting for three or four hours for dinner at a clearing where an inn and store have been built. The pace was from ten to fifteen miles an hour. After the first twenty miles, during which one still has glimpses of the strange isolated peaks that spring up here and there from the plain, the scenery becomes rather monotonous, for the line runs most of the way through thick forest, the trees higher than those of the interior, yet not of any remarkable beauty. For the last twenty-five miles the railway traverses a dead and dreary flat. The 
gentle rise of the ground to the west conceals even the outlying spurs of the great range behind, and to the north and south there is an unbroken level. The soil is said to be generally poor, a very thin layer of vegetable mould lying over sand, and the trees are few and seldom tall. It is a country full of all sorts of game, from buffaloes, elands, and koodoos downward to the small antelopes; and as game abounds, so also do lions abound. The early morning is the time when most of these creatures go out to feed, and we strained our eyes as soon as there was light enough to make them out from the car windows. But beyond some wild pig and hartebeest, and a few of the smaller antelopes, nothing could be discerned upon the pastures or among the tree clumps. Perhaps the creatures have begun to learn that the railroad brings their enemies, and keep far away from it. A year after our visit the murrain, to which I have already referred, appeared in this region, and has now wrought fearful devastation among the wild animals, especially the buffaloes.

The railway now runs all the way from Chimoyo to the port of Beira, but in October, I895, came to an end at a place called Fontesvilla, on the Pungwe River, near the highest point to which the tide rises. We had therefore to take to the water in order to reach Beira, where a German steamer was timed to call two days later ; and our friends in Mashonaland had prepared us to expect some disagreeable experiences on the river, warning us not to assume that 
twelve or fourteen hours would be enough, even in a steamer, to accomplish the fifty miles of navigation that lie between Fontesvilla and the sea. They had been specially insistent that we should remain in Fontesvilla itself no longer than was absolutely necessary; for Fontesvilla has the reputation of being the most unhealthy spot in all this unhealthy country. We were told that the preceding year had been a salubrious one, for only forty-two per cent. of the European residents had died. There may have been in these figures some element of exaggeration, but the truth they were intended to convey is beyond dispute; and the bright young assistant superintendent of the railroad was mentioned, with evident wonder, as the only person who had been more than three months in the place without a bad attack of fever. Fontesvilla has not the externals of a charnel-house. It consists of seven or eight scattered frame houses, with roofs of corrugated iron, set in a dull, featureless flat on the banks of a muddy river. The air is sultry and depressing, but has not that foul swamp smell with which Poti, on the Black Sea, reeks, the most malarious spot I had ever before visited. Nor was there much stagnant water visible; indeed, the ground seemed dry, though there are marshes hidden among the woods on the other side of the river. As neither of the steamers that ply on the Pungwe could come up at neap tides, and with the stream low,-for the rains had not yet set in,- - the young superintendent (to whose friendly help we were much beholden) had 
bespoken a rowboat to come up for us from the lower part of the river. After waiting from eight till half-past ten o'clock for this boat, we began to fear it had failed us, and, hastily engaging a small two-oared one that lay by the bank, set off in it down the stream. Fortunately after two and a half miles the other boat, a heavy old tub, was seen slowly making her way upward, having on board the captain of the little steam-launch, the launch herself being obliged to remain much lower down the river. We transferred ourselves and our effects to this boat, and floated gaily down, thinking our troubles over.

The Pungwe is here about one hundred yards wide, but very shallow, and with its water so turbid that we could not see the bottom where it was more than two feet below the surface. It was noon; the breeze had dropped, and the sun was so strong that we gladly took refuge in the little cabin or rather covered box-a sort of hen coop-at the stern. The stream and the tide were with us, and we had four native rowers, but our craft was so heavy that we accomplished less than two miles an hour. As the channel grew wider and the current spread itself hither and thither over sand banks, the bed became more shallow, and from time to time we grounded. When this happened, the native rowers jumped into the water and pushed or pulled the boat along. The farther down we went, and the more the river widened, so much the more often did we take the bottom, and the harder did we find it to get afloat 
again. Twelve miles below Fontesvilla, a river called the Bigimiti comes in on the right, and at its mouth we took on board a bold young English sportsman with the skin of a huge lion. Below the confluence, where a maze of sand banks encumbers the channel, we encountered a strong easterly breeze. The big clumsy boat made scarcely any way against it, and stuck upon the sand so often that the Kafirs, who certainly worked with a will, were more than half the time in the water up to their knees, tugging and shoving to get her off. Meanwhile the tide, what there was of it, was ebbing fast, and the captain admitted that if we did not get across these shoals within half an hour we should certainly lie fast upon them till next morning at least, and how much longer no one could tell. It was not a plesant prospect, for we had no food except some biscuits and a tin of cocoa, and a night on the Pungwe, with pestiferous swamps all round, meant almost certainly an attack of fever. Nothing, however, could be done beyond what the captain and the Kafirs were doing, so that suspense was weighted by no sense of personal responsibility. We moved alternately from stern to bow, and back from bow to stern, to lighten the boat at one end or the other, and looked to windward to see from the sharp curl of the waves whether the gusts which stopped our progress were freshening further. Fortunately they abated. Just as the captain seemed to be giving up hope-the only fault we had with him was that his face revealed too plainly his 
anxieties-we felt ourselves glide off into a deeper channel ; the Kafirs jumped in and smote the darkbrown current with their oars, and the prospect of a restful night at Beira rose once more before us. But our difficulties were not quite over, for we grounded several times afterwards, and progress was so slow that it seemed very doubtful whether we should find and reach before dark the little steamlaunch that had come up to meet us.

Ever since my childish imagination had been captivated by the picture of Afric's sunny fountains rolling down their golden sand, the idea of traversing a tropical forest on the bosom of a great African river had retained its fascination. Here at last was the reality, and what a dreary reality! The shallow, muddy stream, broken into many channels, which inclosed low, sandy islets, had spread to a width of two miles. The alluvial banks, rising twenty feet in alternate layers of sand and clay, cut off any view of the country behind. All that could be seen was a fringe of thick, low trees, the edge of the forest that ran back from the river. Conspicuous among them was the ill-omened "fever tree " with its gaunt, bare, ungainly arms and yellow bark-the tree whose presence indicates a pestilential air. Here was no luxuriant variety of form, no wealth of colour, no festooned creepers nor brilliant flowers, but a dull and sad monotony, as we doubled point after point and saw reach after reach of the featureless stream spread out before us. Among the trees not a bird was to be seen or heard; few even fluttered 
on the bosom of the river. We watched for crocodiles sunning themselves on the sand-spits, and once or twice thought we saw them some two hundred yards away, but they had always disappeared as we drew nearer. The beast is quick to take alarm at the slightest noise, and not only the paddles of a steamer, but even the plash of oars, will drive him into the water. For his coyness we were partly consoled by the gambols of the river-horses. All round the boat these creatures were popping up their huge snouts and shoulders, splashing about, and then plunging again into the swirling water. Fortunately none rose quite close to us, for the hippopotamus, even if he means no mischief, may easily upset a boat when he comes up under it, or may be induced by curiosity to submerge it with one bite of his strong jaws, in which case the passengers are likely to have fuller opportunities than they desire of becoming acquainted with the crocodiles.

Among such sights the sultry afternoon wore itself slowly into night, and just as dark fellit falls like a stage-curtain in these latitudes-we joyfully descried the steam-launch waiting for us behind a sandy point. Once embarked on her, we made better speed through the night. It was cloudy, with a struggling moon, which just showed us a labyrinth of flat, densely wooded isles, their margins fringed with mangrove-trees. Exhausted by a journey of more than thirty hours without sleep, we were now so drowsy as to be in constant danger of falling off the tiny launch, which had neither seats 
nor bulwarks, and even the captain's strong tea failed to rouse us. Everything seemed like a dreamthis lonely African river, with the faint moonlight glimmering here and there upon its dark bosom, while the tree tops upon untrodden islets flitted past in a slow, funereal procession, befitting a land of silence and death.

At last, when it was now well past midnight, a few lights were seen in the distance, and presently we were at Beira. As we touched the shore we were told that the German steamer had already arrived, two days before her time, and was to start in the morning at ten o'clock. So we made straight for her, and next day at noon sailed for Delagoa Bay.

Beira stands on a sand-spit between the ocean and the estuary of the Pungwe River. Though the swamps come close up to it, the town itself is tolerably healthy at all seasons, because the strong easterly breeze blows from the sea three days out of four. Six years ago there was hardly even a house, and its quick growth is entirely due to its having been discovered to possess the best harbour on the coast, and to be therefore the fittest point of departure from the sea for the territories of the British South Africa Company.

In old days the chief Portuguese settlement on this part of the coast was at Sofala, a few miles farther to the south, which had been visited by Vasco da Gama in A.D. I5O2, and where the Portuguese built a fort in 1505 . It was then an Arab town, and famous as the place whence most of 
the gold brought down from the interior was exported. Now it has shrunk to insignificance, and Beira will probably become the most important haven on the coast between Delagoa Bay, to the south, and Dar-es-Salaam, the headquarters of German administration, to the north. It may, however, be rivalled by Pemba Bay north of the Zambesi, from which it is proposed to run a railway to the south end of Lake Nyassa. The anchorage in the estuary behind the sand-spit is spacious and sheltered, and the outrush of the tide from the large estuary keeps down, by its constant scour, accumulations of sand upon the bar. The rise of tide at this part of the coast, from which Madagascar is only four hundred miles distant, is twenty-two feet, and the channel of approach, though narrow and winding (for the coast is shallow and there are shoals for six or eight miles out), is tolerably well buoyed and not really difficult. The railway terminus is being erected at a point within the harbour where the sand-spit joins the mainland, and here a quay is also being built for the discharge of goods direct to the trucks.

The journey which I have described, with all its difficulties, first on the river between Beira and Fontesvilla, and then again on the track between Chimoyo and Mtali, will soon be a thing of the past. Early in 1896 the railway was opened from Fontesvilla to Beira, so that the tedious and vexatiously uncertain voyage up or down the Pungwe River is now superseded by a more swift if 
less exciting form of travel. At the other end of the railroad the permanent way is being rapidly laid from Chimoyo to Mtali, so that trains will probably be running all the way from the sea to Mtali by the end of I897, and to Fort Salisbury before the end of the century. It will then be possible to go from Beira to Mtali in fourteen or sixteen hours, to Fort Salisbury in twenty or twenty-four. Should the resources of Mashonaland turn out within the next few years to be what its more sanguine inhabitants assert, its progress will be enormously accelerated by this line, which will give a far shorter access to South Central Africa than can be had by the rival lines that start from Cape Town, from Durban, and from Delagoa Bay. 


\section{CHAPTER XVII}

OBSERVATIONS ON THE RESOURCES AND FUTURE

OF MATABILILAND AND MASHONALAND

In the last chapter I have brought the reader back to the sea from those inland regions we have spent three chapters in traversing. Now, while the German steamer is threading her way to the open ocean through the shoals that surround the entrance to the harbour of Beira, the traveller as he gazes on the receding shore tries to sum up his impressions regarding the economic prospects as well of Mashonaland as of the other territories of the British South Africa Company. I will shortly state these impressions.

The regions over which the British flag flies between the Transvaal Republic to the south and the territories of Germany and of the Congo State to the north, fall into three parts. The first is the country north of the Zambesi. The eastern section of this northerly region is Nyassaland, of which I need say nothing, because it has just been admirably described by the distinguished officer (Sir H. H. Johnston) who administered it for some years. 
The western section, which is under the control of the Company, is still too little known for an estimate of its value to be formed. Though some parts of it are more than 4000 feet above sea-level, most of it lies below that line, which is, roughly speaking, the line at which malarial fevers cease to be formidable. Most of it, therefore, is not likely to be fit for European colonisation, and the heat is of course such as to put European labour out of the question. Considerable tracts are, however, believed to be fertile, and other tracts good for pasture, while there is some evidence of the existence of gold and other minerals. The least valuable region is believed to be that north of the Middle Zambesi, where there are some dry and almost barren districts. Taking it all in all, it is a country well worth having; but its resources will have to be turned to account entirely through black labour; and as it is not likely to attract any Europeans, except gold-prospectors, until the unoccupied lands south of the Zambesi have been fully taken up, its development belongs to a comparatively distant future.

The second region-that which lies south of the Upper Zambesi, northwest of Matabililand-is equally little known, and, so far as known, is not attractive. Most of it is comparatively low ; much of it is arid; some parts, especially those round Lake Ngami, are marshy and therefore malarious. It is thinly peopled, has not been ascertained to possess any mineral wealth, and lies far from any possible market. Parts of it may turn out to afford 
CHAP.

good pasture, but for the present little is said or thought about it, and no efforts have been made to develop it.

The third region comprises Matabililand and Mashonaland, that is, the country between the Transvaal Republic and the valley of the Middle Zambesi, all of which is now administered by the Company. What there is to say about its prospects may be summed up under three heads-health, wealth, and peace. It is on these three things that its future welfare depends.

Health.-A large part of the country, estimated at nearly 100,000 square miles, belongs to the upper South African Plateau, and has an elevation of at least 3000 feet above the sea; and of this area about 26,000 square miles have an elevation of 4000 feet or upward. This height, coupled with fresh easterly breezes and dry weather during eight months in the year, gives the country a salubrious and even bracing climate. The sun's heat is tempered, even in summer, by cool nights, and in winter by cold winds, so that European constitutions do not, as in India, become enervated and European muscles flaccid. It is not necessary to send children home to England when they reach five or six years of age; for they grow up as healthy as they would at home. Englishmen might, in many districts, work with their hands in the open air, were they so disposed; it is pride and custom, rather than the climate, that forbid them to do so. So far, therefore, the country is one in which an indigenous 
white population might renew itself from generation to generation.

Wealth.-It was the hope of finding gold that drew the first British pioneers to these regions; it is that hope which keeps settlers there, and has induced the ruling Company to spend very large sums in constructing railways, as well as in surveying, policing, and otherwise providing for the administration of the country. The great question, therefore, is, How will the gold-reefs turn out? There had been formed before the end of I 895 more than two hundred Development Companies, most of them gold-mining undertakings, and others were being started up till the eve of the native outbreak in March 1896. Very many reefs had been prospected and an immense number of claims registered. The places in which actual work had been done in the way of sinking shafts and opening adits were, of course, much fewer, yet pretty numerous. Most of these were in Manicaland, near Mtali, or to the north and west of Fort Salisbury, or to the southeast of Gwelo, in the Selukwe district. No one of these workings was on a large scale, and at two or three only had stamping machinery been set up, owing, so I was told, to the practically prohibitive cost of transport from the sea. Accordingly, there are very few, if any, workings where enough ore has been extracted and treated to warrant any confident predictions as to the productivity of the claim. Numerous as the claims are, the value of all, or nearly all, is still practically uncertain. 
It must be remembered that in these mining districts the gold occurs in quartz-reefs. Comparatively little is found in alluvial deposits, which in California and Australia and the Ural Mountains have been often more important than the quartzreefs. None at all is found diffused equally through a stratum of rock, as in the Transvaal. Now, quartz-reef mining is proverbially uncertain. The reefs vary not only in thickness, but also in depth, and it is not yet certain that any go very far beneath the surface. So, too, even when the reef itself is persistent in width and in depth, its auriferous quality varies greatly. What is called the "shoot" of gold may be rich for some yards, and then become faint or wholly disappear, perhaps to reappear some yards farther. Thus there must be a good deal of quartz crushed at different points before it can be determined what number of pennyweights or ounces to the ton a given reef, or a given part of a reef, is likely to yield.

In this uncertainty and deficiency of practical tests, people have fallen back upon the ancient workings as evidence of the abundance of the precious metal. I have already mentioned how numerous these workings are over the country, and how fully they appear to confirm the stories as to the gold which was brought down in the sixteenth and seventeenth centuries to Sofala and the other Portuguese ports. It is argued that if gold was so extensively worked in time past by rude races possessing only primitive methods and few tools, the 
reefs must have been rich, and that it is extremely improbable that all, or nearly all, the gold should have been already extracted. The old workings were open, excavated down from the surface, and they usually stopped when water was reached. Is there not every reason to think that in many places the reefs go deeper, and that our improved scientific appliances will enable us to extract far more of the metal than the old miners could get by their simple breaking and washing of the quartz? No doubt the old workings were carried on by labour incomparably cheaper than could now be obtained; but against this may be set the greater efficiency of the machinery which will be at the disposal of the miner when transportation facilities have been provided.

Arguments of this kind are resorted to only because the data which experiment has hitherto supplied are insufficient. There is much difference of opinion in the country itself regarding the value of the reefs. Some mining engineers whom I questioned took a less sanguine view of the reefs they had examined than did the general public in Fort Salisbury or Bulawayo, and (it need hardly be said) a much less sanguine view than the prospectuses of the companies conveyed to investors at home. On the other hand, results had been actually obtained in some other places which promised extremely well if the rest of the reef proved equal to the portion sampled. Men of what is called in America "a conservative temper" seemed to me to think that there is "payable gold," probably plenty of 
CHAP.

gold, in the country, and that out of the many companies formed to work the claims a fair, but by no means a large, proportion will turn out sound undertakings. I doubt if it will be possible to say anything more positive until stamping batteries have been erected and a considerable quantity of quartz has been treated. This process can hardly begin till the railways to Bulawayo and Mtali have been opened, and those interested may therefore have to wait till 1899 or 1900 before they can feel sure as to the value of their properties.

Other minerals besides gold have been found. There is iron in many places, copper in others. Coal has been proved to exist, of good if not firstrate quality, on the edge of the Zambesi Valley north-west and north of Gwelo and Fort Salisbury, and if the gold-reefs turn out well it will certainly be worked.

Regarding the pastoral and agricultural capabilities of the country there need be little doubt. All of it, except those lower grounds to the north and southeast which are infested by the tsetse-fly, is fit for cattle; some parts, such as the Matoppo Hills in Matabililand, and still more the Inyanga Plateau in Mashonaland (mentioned in the last preceding chapter), offer excellent pasture. The "high veldt" of central Matabililand is no less available for sheep. Most of the cattle that were on the land have perished in the recent murrain. But this plague will pass by and may not return for many years, perhaps for centuries, and the animals that will be 
brought in to restock the country will probably be of better breeds. The quality of the soil for the purposes of tillage has been tested by Europeans in a few places only. Much of it is dry; much of it, especially where the subjacent rock is granitic, is thin or sandy. Still, after allowing for these poorer tracts, there remains an immense area of land which is fit to raise cereals and some subtropical crops such as cotton. The immediate question is not, therefore, as to the productive capacities of the country, but as to the existence of a market for the products themselves. Nearly all staple food-stuffs have of late years become so cheap in the markets of Europe and North America, owing to the bringing under cultivation of so much new land and the marvellous reduction in the cost of ocean carriage, that in most of such articles Mashonaland, even with a railway to the sea, could not at present compete successfully in those markets with India and South America and the western United States. It is therefore to consumers nearer at hand that the country must look. If gold-mining prospers, population will rapidly increase, and a market will be created at the agriculturists' own door. If, on the other hand, the reefs disappoint the hopes formed of them, and the influx of settlers is too small to create any large demand, tillage will spread but little, and the country will be left to be slowly occupied by ranchmen. Thus the growth of population and the prosperity of every industry will depend upon the extent to which gold-mining can be profit- 
CHAP.

ably developed. Of course I speak only of the near future. However rich some of the reefs may turn out, they will be exhausted within a few decades, and the country will have to depend on its other resources. However unremunerative the reefs may prove, those other resources will in the long run assure to it a settled white population and a reasonable measure of prosperity. But these are days in which we all have learned to take short views of life for nations and countries as well as for our individual selves, and unquestionably the more or less of gold in its quartz will for this country make all the difference between its speedy and its slow development.

Peace. - Thirdly, there remains the question whether the natives can be kept quiet. The first occupation of Mashonaland was so tranquil, the first conquest of the Matabili so swift and easy, that everybody'can now see that some further trouble ought to have been expected before British control could be deemed secure. Now there has been a second struggle and a pacification if not a victory. Has the suppression of the revolt given permanent security? Are the natives at last aware that the superiority of intelligence and organization on the part of the whites more than counterbalances their own immense preponderance in numbers, a preponderance of fully one hundred to one? No one will speak confidently on this point who remembers how implicit and how vain was the confidence felt in 1895 that the natives were contented and submissive. Nevertheless, there is reason to think that if the 
natives are ruled in a prudent and friendly spirit, making due allowance for their often unreasonable alarms and suspicions, no fresh rising need be feared. The chief aim of the ruling officials should be to draw and not to drive them to labour, and to keep in check those white adventurers who hang about the frontiers of civilization and sometimes ill-use or defraud the Kafir in a way which makes him hostile to the next whites, however well intentioned, who come into his neighbourhood. It may be some years yet before the natives will seek work at the mines to the extent desired, for they dislike underground labour. But policy, as well as humanity and justice, forbids any resort to compulsion. Though it is quite true that the native hates to see the white men come in, disturb his old way of life, and take the best land, still I doubt if anything less than some positive grievance, such as forced labour or the taking of cattle, will be likely to rouse him to another attack on the strangers. Should such an attack occur, it would be less formidable than that of 1896 . The tribal system, already weakened, tends among the Matabili to dissolve still further, as was seen by the absence of notable leaders and the general want of plan and co-operation in the late conflict. Among the Mashonas each village is independent, so that a combined effort is still less to be feared. ${ }^{1} \quad$ Moreover,

1 This "very isolation and independence of the small native communities in Mashonaland has however retarded the pacification of the country during 1896-97. There are hardly any influential chiefs with whom to treat. 
CHAP.

the completion of the two railways to Bulawayo on the western and Fort Salisbury on the eastern side of the country will enable reinforcements to be rapidly sent up from the coast, and remove the only danger that really threatened the whites in $1896-$ their isolation from help and from supplies of ammunition and of food.

What, then, are the general conclusions to which this rapid survey leads? I will summarize them.

I. Though parts of the country will remain malarious, great areas will be sufficiently healthy to enable a large white population to grow up and maintain itself on the soil in vigour of mind and body. In this sense it will be a "white man's country."

2. The black population is, however, likely to remain by far the more numerous element, partly because it is better fitted for the malarious and the hottest regions, and partly because here, as elsewhere in South Africa, it is by the blacks that nearly all manual labour will continue to be done. In this sense, that of numerical preponderance, the country, and of course especially the parts of it which lie near to and north of the Zambesi, will be a "black man's country."

3. The material progress of the country, and the more or less rapid increase of its white population, will depend, in the first instance, on the greater or less success with which gold-mining is prosecuted. If the reefs turn out well, growth will be rapid; if not, it will be slow. But in the long run the soil 
and the climate will be the main factors in material and social prosperity. These give abundant grounds for hope. The rainfall is larger than in the interior of Cape Colony, and much of the soil will therefore be more productive. Therewith other industries will spring up; and some of them will remain even when mining has declined.

4. The political future will depend upon the growth of population, as that depends upon the development of material resources. Should there be a large and steady influx of white settlers, there must before long come a demand for self-governing institutions. To concede these institutions will be in the well-established line of British colonial policy, and the question will then arise whether the country, or the more settled parts of it, should form a separate colony or be incorporated with Cape Colony (as British Bechuanaland recently was). That one found in 1895 very little disposition among the white settlers to grumble at the administration seemed chiefly due to the great personal popularity of the genial Administrator, Dr. L. S. Jameson. A committee of the House of Commons was recently appointed to inquire into the use the Company had made of its powers, but it has not yet (July, I 897) reported upon that subject.

5. Whether the present form of government by the British South Africa Company, with the cooperation of a council partly nominated by the High Commissioner for South Africa, and under the general oversight of that officer, should for the 
CHAP.

present continue, or whether, as some have urged, these vast territories should come under the direct control of the Imperial Government as a Crown Colony, is a question that need not be discussed here. It must, however, be ere long considered by the British Cabinet and Legislature; and it will give them some trouble, for it is involved with personal questions on one side, and with financial questions on the other.

6. Leaving out of sight the still unsettled problem of the mineral wealth of these territories, they are in other respects one of the most promising parts of South Africa. I have remarked that as regards pasture and agriculture they are superior to the inland parts of Cape Colony. They are in these points also superior to the Transvaal, and still more plainly superior to the neighbouring possessions of Germany and Portugal. Portuguese East Africa is fever-stricken. German East Africa is in many places barren and almost everywhere malarious. German South-west Africa is largely desert, much of it an arid and irreclaimable desert.

To the English race in South Africa the acquisition of these regions, or at least of the parts south of the Zambesi, has been an immense political and economic advantage. It has established their predominance and provided a security against any serious attempt to dislodge them. And a philosophic observer without predilections for any one state or people would, it is conceived, hold that the English race is more likely to serve what are termed 
the interests of civilization in this part of Africa than is any other race. The Portuguese have neither energy nor capital. The Germans, with energy and with capital, have not the requisite practice in independent colonization, nor perhaps the taste for it. The South African Dutch Boers, who have within the last fifteen years been more than once on the point of occupying the country, are, with all their good qualities, a backward people, who, had they prevailed, would have done little more than squat here and there over the country with their cattle, and carry on an incessant desultory war with the natives. Whether it is really desirable that the waste lands of the world should be quickly brought under settled order and have their resources developed with all possible speed, is a question on which much might be said. But assuming, as most men (perhaps too hastily) do assume, that this sudden development is desirable, the English are the people most likely to carry it out effectively, and the strong and strenuous man who, with little encouragement from the government of his country, founded the British South Africa Company and acquired these territories for his countrymen, took one of the most fateful steps that statesman or conqueror has ever taken in the African continent. 


\section{CHAPTER XVIII}

\section{THROUGH NATAL TO THE TRANSVAAL}

THERE are two ways of reaching the Witwatersrand gold-fields, now the central point of attraction in South Africa, from the south-east coast. One route starts from Delagoa Bay, a place of so much importance as to deserve a short description. It is a piece of water protected from the ocean by Inyack Island, and stretching some twenty miles or more north and south. At the north end, where two rivers discharge their waters into it, is an almost landlocked inlet, on the east side of which stands the town of Lourenço Marques, so called from the Portuguese captain who first explored it in I544, though it had been visited in $\mathrm{I}_{502}$ by Vasco da Gama. The approach to this harbour is long and circuitous, for a vessel has to wind hither and thither to avoid shoals; and as the channel is ill buoyed, careful captains sometimes wait for the tide to be at least half full before they cross the shallowest part, where there may be only twenty feet of water at low tide. Within the harbour there is plenty of good deep anchorage opposite the town, and a still more 
sheltered spot is found a little farther up the inlet in a sort of lagoon. The town, which is growing fast, but still in a rough and unsightly condition, runs for half a mile along the bay front, and behind rises up the slope of a hill facing to the west. The site looks healthy enough, though it would have been better to plant the houses nearer to the high point which shields the anchorage. But behind the town to the east and north there are large swamps, reeking with malaria; and the residents have, therefore, though of course much less in the dry season, to be on their guard against fever, which, indeed, few who remain for a twelvemonth escape. The Portuguese government is unfortunately hard pressed for money and has not been able to complete the projected quays, nor even to provide a custom-house and warehouses fit to receive and store the goods intended for the Transvaal, which are now discharged here in large quantities. In November, I895, everything was in confusion, and the merchants loud in their complaints. Business is mostly in English and German, scarcely at all in Portuguese, hands. With better management and the expenditure of a little money, both the approach to the harbour and the town itself might be immensely improved; and although the country round is not attractive, being mostly either sandy or marshy, the trade with the Transvaal gold-fields seems so certain to develop and maintain itself that expenditure would be well bestowed. It has often been suggested that Great Britain should buy the place (over which she has a 
right of pre-emption), but the sensitive pride of Portugal would probably refuse any offer.

The other port which now competes for the Transvaal trade with Delagoa Bay is Durban, the largest town in the British colony of Natal. It stands on a sandy flat from which a spit of land runs out into the sea between the open ocean and the harbour. The harbour is commodious, but the bar on the channel connecting it with the ocean formerly made it unavailable except for vessels of light draft. Much has been done by the colony to deepen the channel, ${ }^{1}$ and at the time of my visit a new dredger was on its way, from the exertions of which great things were hoped. Heretofore the largest steamers have had to lie out in the ocean a mile or two away, and as there is usually a swell, in which the little steam-tenders pitch about pretty freely, the process of disembarkation is trying to many passengers. There is, however, good reason to hope that the bar difficulties may ultimately be overcome, as they have already been greatly reduced: and the harbour, once you are within it, is perfectly sheltered.

Durban is a neat and, in some parts, even handsome town, with wide and well-kept streets, to which the use of slender jinrikshas (drawn by active Zulus or Indians) instead of cabs, as well as the number of white-clad coolies in the streets, gives a curious Eastern touch, in keeping with the semi-tropical

1 Special credit was attributed to Mr. Escombe, then attorneygeneral, for his advocacy of this enterprise. 
vegetation. The climate is sultry during three months, but very agreeable for the rest of the year. Many of the whites, however,- -there are 14,000 of them, and about the same number of Kafirs and immigrants from India,- - live on the hill of Berea to the north of the town, where the sea breeze gives relief even in the hottest weather. This suburb of Berea is one of the prettiest spots in South Africa. The name, of which the origin seems to have been forgotten by the citizens of to-day, comes from a missionary settlement planted here in very early days, and called after the Berea mentioned in Acts xvii. IO, II. It has been skilfully laid out in winding roads, bordered by tasteful villas which are surrounded by a wealth of trees and flowering shrubs, and command admirable views of the harbour, of the bold bluff which rises west of the harbour, and of the ocean. The municipality bought the land, and by selling or leasing it in lots at increased prices has secured a revenue which has kept local taxation at a very low figure, and has enabled many town improvements to be made and many enterprises to be worked for the benefit of the citizens. Durban has been a pioneer of what is called, in its extremer forms, municipal socialism; and it enjoys the reputation of being the best managed and most progressive town in all South Africa. It possesses among other things a fine town-hall with a lofty tower, built by the exertions of the present mayor, a deservedly respected Scotch merchant.

East of Durban a low and fertile strip of country 
stretches along the coast, most of which is occupied by sugar plantations, tilled by coolies brought from India, because the native Kafir does not take kindly to steady labour. North of the town the country rises, and here the patient industry of other Indians has formed a great mass of gardens, where subtropical and even some tropical fruits are grown in great quantities, and have now begun to be exported to Europe. Across this high ground, and through and over the still higher hills which rise farther inland, the railway takes its course, often in steep inclines, to the town of Pietermaritzburg, eighty miles distant, where the Governor dwells, and a small British garrison is placed. Durban was from the first an English town, and the white people who inhabit it are practically all English. Maritzburg was founded by the emigrant Boers who left Cape Colony in the Great Trek of 1836 , and descended hither across the Quathlamba Mountains in 1838 . Its population is, however, nowadays much more British than Boer, but the streets retain an oldfashioned half-Dutch air; and the handsome Parliament House and Government Offices look somewhat strange in a quiet and straggling country town. Its height above the sea (2500 feet) and its dry climate make it healthy, though, as it lies in a hollow among high hills, it is rather hotter in summer than suits English tastes. The surrounding country is pretty, albeit rather bare; nor is the Australian wattle, of which there are now large plantations in the neighbourhood, a very attractive tree. 
This seems the fittest place for a few words on the public life of Natal, the British colony which has been the latest to receive responsible selfgovernment. This gift was bestowed upon it in I 893, not without some previous hesitation, for the whole white population was then about 46,000 , and the adult males were little over I 5,000. However, the system then established seems to be working smoothly. There is a cabinet of five ministers, with two Houses of Legislature, an Assembly of thirtyseven and a Council of eleven members, the former elected for four years at most (subject to the chance of a dissolution), the latter appointed by the Governor for ten years. No regular parties have so far been formed, nor can it yet be foreseen on what lines they will form themselves, for the questions that have chiefly occupied the legislature are questions on which few differences of principle have as yet emerged. All the whites are agreed in desiring to exclude Kafirs and newcomers from India from the electoral franchise. All are agreed in approving the present low tariff, which is for revenue only; and Natal has one of the lowest among the tariffs in force in British colonies. (The ordinary ad valorem rate is five per cent.) Even between the citizens of English and those of Dutch origin, the latter less than one fourth of the whole and living chiefly in the country, there has been but little antagonism, for the Dutch, being less numerous than in Cape Colony, are much less organized. Among the English, British sentiment is strong, for the war of 
CHAP.

I88I with the Transvaal people not merely reawakened the memories of the Boer siege of Durban in 1842 , but provoked an anti-Boer feeling, which is kept in check only by the necessity of conciliating the Transvaal government in order to secure as large as possible a share of the import trade into that country. As the Natal line of railway is a competitor for this trade with the Cape lines, as well as with the line from Delagoa Bay, there is a keen feeling of rivalry toward Cape Colony, which is thought to have been unfriendly in annexing the native territories of Griqualand East and Pondoland, which lie to the west of Natal, and which the latter colony had hoped some day or other to absorb. When her hopes of territorial extension were closed on that side, Natal began to cast longing eyes on Zululand, a hilly region of rich pastures which is at present directly administered by the Imperial Government, and which contains not only some gold-reefs of still unascertained value, but also good beds of coal. And now (I 897) the home government has consented to allow Natal to absorb both Zululand and the Tonga country all the way north to the Portuguese frontier.

The political life of Natal flows in a tranquil current, because the population is not merely small, but also scattered over a relatively wide area, with only two centres of population that rise above the rank of villages. The people, moreover, lead an easy and quiet life. They are fairly well off, occupying large cattle-farms, and with no great induce- 
ment to bring a great deal of land under tillage, because the demand for agricultural produce is still comparatively small. Not much over one-fortieth part of the surface is cultivated, of which about two hundred thousand acres are cultivated by Europeans, of course by the hands of coloured labourers. Sugar is raised along the coast, and tea has lately begun to be grown. The Natalians have, perhaps, become the less energetic in developing the natural resources of their country because thrice in their recent history the equable course of development has been disturbed. In 1870 many of the most active spirits were drawn away to the newlydiscovered diamond-fields of Kimberley. In 1879 the presence of the large British force collected for the great Zulu war created a sudden demand for all sorts of food-stuffs and forage, which disappeared when the troops were removed; and since I886 the rapid growth of the Witwatersrand gold-fields, besides carrying off the more adventurous spirits, has set so many people speculating in the shares of mining companies that steady industry has seemed a slow and tame affair. At present not many immigrants come to Natal to settle down as farmers; and the colony grows but slowly in wealth and population. Nevertheless, its prosperity in the long run seems assured. It is more favoured by soil and by sky than most parts of Cape Colony. It has an immense resource in its extensive coal-fields. Its ocean trade and railway traffic are increasing. In proximity to these coal-fields it has deposits of 
CHAP.

iron which will one day support large industrial communities. And its inhabitants are of good, solid stuff, both English, Dutch, and German, for there are many German immigrants. No British colony can show a population of better quality, and few perhaps one equally good.

Besides the railway question, which is bound up with the problem of the port of Durban and its bar, the question which has most interest for the people of Natal is that of the coloured population, Kafir and Indian. The Kafirs, mostly of Zulu race, number 460,000, about ten times the whites, who are estimated at 50,000. Nearly all live under tribal law in their own communities, owning some cattle, and tilling patches of land which amount in all to about 320,000 acres. The law of the colony wisely debars them from the use of European spirits. A few of the children are taught in mission schools,the only educational machinery provided for them,and a very few have been converted to Christianity, but the vast majority are little influenced by the whites in any way. They are generally peaceable, and perpetrate few crimes of violence upon whites; but however peaceable they may have shown themselves, their numerical preponderance is disquieting. A Kafir may, by the Governor's gift, obtain the electoral suffrage when he has lived under European law for at least seven years; but it has been bestowed on extremely few, so that in fact the native does not come into politics at all. The Indian immigrants, now reckoned at 50,000, are of two classes. 
Some are coolies, who have been imported from India under indentures binding them to work for a term of years, chiefly on the sugar plantations of the coast. Many of these return at the expiration of the term, but more have remained, and have become artisans in the towns or cultivators of garden patches. The other class, less numerous, but better educated and more intelligent, consists (besides some free immigrants of the humbler class) of so-called "Arabs"Mohammedans, chiefly from Bombay and the ports near it, or from Zanzibar-who conduct retail trade, especially with the natives, and sometimes become rich. Clever dealers, and willing to sell for small profits, they have practically cut out the European from business with the natives, and thereby incurred his dislike. The number of the Indians who, under the previous franchise law, were acquiring electoral rights had latterly grown so fast that, partly owing to the dislike I have just mentioned, partly to an honest apprehension that the Indian element, as a whole, might become unduly powerful in the electorate, an act was recently (1894) passed by the colonial legislature to exclude them from the suffrage. The home government was not quite satisfied with the terms in which this act was originally framed, but has now (I 897) approved an amended act which provides that no persons shall be hereafter admitted to be electors "who (not being of European origin) are natives or descendants in the male line of natives of countries which have not hitherto possessed elective representative institutions founded on the parlia- 
mentary franchise, unless they first obtain from the Governor in Council an order exempting them from the provisions of this act." Under this statute the right of suffrage will be withheld from natives of India and other non-European countries, such as China, which have no representative government, though power is reserved for the government to admit specially favoured persons. In 1897 another act was passed (and approved by the home government) which permits the colonial executive to exclude all immigrants who cannot write in European characters a letter applying to be exempted from the provisions of the law. It is intended by this measure to stop the entry of unindentured Indian immigrants of the humbler class.

I have referred particularly to this matter because it illustrates one of the difficulties which arise wherever a higher and a lower, or a stronger and a weaker, race live together under a democratic government. To make race or colour or religion a ground of political disability runs counter to what used to be deemed a fundamental principle of democracy, and to what has been made (by recent amendments) a doctrine of the American Constitution. To admit to full political rights, in deference to abstract theory, persons who, whether from deficient education or want of experience as citizens of a free country, are obviously unfit to exercise political power is, or may be, dangerous to any commonwealth. Some way out of the contradiction has to be found, and the democratic Southern 
States of the North American Union and the oligarchical republic of Hawaii, as well as the South African colonies, are all trying to find such a way. Natal, where the whites are in a small minority, now refuses the suffrage to both Indians and Kafirs ; while Cape Colony, with a much larger proportion of whites, excludes the bulk of her coloured people by the judicious application of an educational and property qualification. The two Boer republics deny the supposed democratic principle, and are therefore consistent in denying all political rights to people of colour. The Australian colonies have taken an even more drastic method. Most of them forbid the Chinese to enter the country, and admit the dark-skinned Polynesian only as a coolie labourer, to be sent back when his term is complete. France, however, is more indulgent, and in some of her tropical colonies extends the right of voting, both for local assemblies and for members of the National Assembly in France, to all citizens, without distinction of race or colour.

Maritzburg is a cheerful little place, with an agreeable society, centred in Government House, and composed of diverse elements, for the ministers of state and other officials, the clergy, the judges, and the officers of the garrison, furnish a number, considerable for so small a town, of capable and cultivated men. There are plenty of excursions, the best of which is to the beautiful falls of the Umgeni at Howick, where a stream, large after the rains, leaps over a sheet of basalt into a noble cirque sur- 
rounded by precipices. Passing not far from these falls, the railway takes its course northward to the Transvaal border. The line climbs higher and higher, and the country, as one recedes from the sea, grows always drier and more bare. The larger streams flow in channels cut so deep that their water is seldom available for irrigation; but where a rivulet has been led out over level or gently sloping ground, the abundance of the crop bears witness to the richness of the soil and the power of the sun. The country is everywhere hilly, and the scenery, which is sometimes striking, especially along the banks of the Tugela and the Buffalo rivers, would be always picturesque were it not for the bareness of the foregrounds, which seldom present anything except scattered patches of thorny wood to vary the severity of the landscape. Toward the base of the great Quathlamba or Drakensberg Range, far to the west of the main line of railway, there is some very grand scenery, for the mountains which on the edge of Basutoland rise to a height of 10,000 feet break down toward Natal in tremendous precipices. A considerable coal-field lies near the village appropriately named Newcastle, and there are valuable deposits near the village of Dundee also, whither a branch line which serves the collieries turns off to the east. Travelling steadily to the north, the country seems more and more a wilderness, in which the tiny hamlets come at longer and longer intervals. The ranching-farms are very large,usually six thousand acres,- - so there are few settlers ; 
and the Kafirs are also few, for this high region is cold in winter, and the dry soil does not favour cultivation. At last, as one rounds a corner after a steep ascent, a bold mountain comes into sight, and to the east of it, connecting it with a lower hill, a ridge or neck, pierced by a tunnel. The ridge is Laing's Nek, and the mountain is Majuba Hill, spots famous in South African history as the scenes of the battles of $188 \mathrm{I}$ in the Transvaal War of Independence. Few conflicts in which so small a number of combatants were engaged have so much affected the course of history as these battles; and the interest they still excite justifies a short description of the place.

Laing's Nek, a ridge 5,500 feet above the sea and rising rather steeply about 300 feet above its southern base, is part of the Quathlamba watershed, which separates the streams that run south into the Indian Ocean from those which the Vaal on the north carries into the Orange River and so to the Atlantic. It is in fact on the south-eastern edge of that great interior table-land of which I have so often spoken. Across it there ran in $\mathrm{I} 88 \mathrm{I}$, and still runs, the principal road from Natal into the Transvaal Republic,- there was no railway here in $188 \mathrm{I}$, -and by it therefore the British forces that were proceeding from Natal to reconquer the Transvaal after the outbreak of December, I880, had to advance to relieve the garrisons beleaguered in the latter country. Accordingly, the Boer levies, numbering about a thousand men, resolved to occupy it, 
CHAP.

and on January 27 they encamped with their waggons just behind the top of the ridge. The frontier lies five miles farther to the north, so that at the Nek itself they were in the territory of Natal. The British force of about one thousand men, with a few guns, arrived the same day at a point four miles to the south, and pitched their tents on a hillside still called Prospect Camp, under the command of General Sir George Colley, a brave officer, well versed in the history and theory of war, but with little experience of operations in the field. Undervaluing the rude militia opposed to him, he next day attacked their position on the Nek in front; but the British troops, exposed, as they climbed the slope, to a well-directed fire from the Boers, who were in perfect shelter along the top of the ridge, suffered so severely that they had to halt and retire before they could reach the top or even see their antagonists. A monument to Colonel Deane, who led his column up the slope and fell there pierced by a bullet, marks the spot. Three weeks later (after an unfortunate skirmish on the 8th), judging the Nek to be impregnable in front, for his force was small, but noting that it was commanded by the heights of Majuba Hill, which rise I,500 feet above it on the west, the British general determined to seize that point. Majuba is composed of alternate strata of sandstone and shale lying nearly horizontal and capped-as is often the case in these mountains-by a bed of hard igneous rock (a porphyritic greenstone). The top is less than a mile in 
circumference, depressed some sixty or seventy feet in the centre, so as to form a sort of saucer-like basin. Here has been built a tiny cemetery, in which some of the British soldiers who were killed lie buried, and hard by on the spot where he fell, is a stone in memory of General Colley. The hill proper is nearly nine hundred feet above its base, and the base about six hundred feet above Laing's Nek, with which it is connected by a gently sloping ridge less than a mile long. It takes an hour's steady walking to reach the summit from the Nek; the latter part of the ascent being steep, with an angle of from twenty to thirty degrees, and here and there escarped into low faces of cliff in which the harder sandstone strata are exposed.

The British general started on the night of Saturday, February 26, from Prospect Camp, left two detachments on the way, and reached the top of the hill, after some hard climbing up the steep west side, at 3 A.M., with something over four hundred men. When day broke, at 5 A.M., the Boers below on the Nek were astonished to see British redcoats on the sky-line of the hill high above them, and at first, thinking their position turned, began to inspan their oxen and prepare for a retreat. Presently, when no artillery played upon them from the hill, and no sign of a hostile movement came from Prospect Camp in front of them to the south, they took heart, and a small party started out, moved along the ridge toward Majuba Hill, and at last, finding themselves still unopposed, began to mount 
CHAP.

the hill itself. A second party supported this forlorn hope, and kept up a fire upon the hill while the first party climbed the steepest parts. Each set of skirmishers, as they came within range, opened fire at the British above them, who, exposed on the upper slope and along the edge of the top, offered an easy mark, while the Boers, moving along far below, and in places sheltered by the precipitous bits of the slope, where the hard beds of sandstone run in miniature cliffs along the hillside, did not suffer in the least from the irregular shooting which a few of the British tried to direct on them. Thus steadily advancing, and firing as they advanced, the Boers reached at last the edge of the hilltop, where the British had neglected to erect any proper breastworks or shelter, and began to pour in their bullets with still more deadly effect upon the hesitating and already demoralized troops in the saucer-like hollow beneath them. A charge with the bayonet might even then have saved the day. But though the order was given to fix bayonets, the order to charge did not follow. General Colley fell shot through the head, while his forces broke and fled down the steep declivities to the south and west, where many were killed by the Boer fire. The British loss was ninety-two killed, one hundred and thirty-four wounded, and fifty-nine taken prisoners; while the Boers, who have given their number at four hundred and fifty, lost only one man killed and five wounded. No wonder they ascribed their victory to a direct interposition of Providence on their behalf. 
The British visitor, to whom this explanation does not commend itself, is stupefied when he sees the spot and hears the tale. Military authorities, however, declare that it is an error to suppose that the occupants of a height have, under circumstances like those of this fight, the advantage which a height naturally seems to give them. It is, they say, much easier for skirmishers to shoot from below at enemies above, than for those above to pick off skirmishers below; and this fact of course makes still more difference when the attacking force are accustomed to hill-shooting, and the defenders above are not. But allowing for both these causes, the attack could not have succeeded had Laing's Nek been assailed from the front by the forces at Prospect Camp, and probably would never have been made had the British on the hill taken the offensive early in the day.

We reached the top of the mountain in a dense cloud, which presently broke in a furious thunderstorm, the flash and the crash coming together at the same moment, while the rain quickly turned the bottom of the saucer-like hollow almost into a lake. When the storm cleared away, what a melancholy sight was this little grassy basin strewn with loose stones, and bearing in its midst the graves of the British dead enclosed within a low wall! A remote and silent place, raised high in air above the vast, bare, brown country which stretched away east, south, and west without a trace of human habitation. A spot less likely to have become the scene of 
CHAP.

human passion, terror and despair can hardly be imagined. Yet it has taken its place among the most remarkable battlefields in recent history, and its name has lived, and lives to-day, in men's minds as a force of lamentable potency.

Crossing Laing's Nek, - the top of which few future travellers will tread, because the railway passes in a tunnel beneath it,-one crosses the main watershed of South Africa, and comes out on the north upon the great rolling plateau which stretches to the Zambesi in one direction and to the Atlantic in another. Four or five miles further, a little beyond the village of Charleston, one leaves Natal and enters the South African Republic. The railway had just been completed at the time of our visit, and though it was not opened for traffic till some weeks later, we were allowed to run over it to the point where it joins the great line from Cape Town to Pretoria. The journey was attended with some risk, for in several places the permanent way had sunk, and in others it had been so insecurely laid that our locomotive and car had to pass very slowly and cautiously. The country is so sparsely peopled that if one did not know it was all taken up in large grazing-farms one might suppose it still a wilderness. Here and there a few houses are seen, and one place, Heidelberg, rises to the dignity of a small town, being built at the extreme south-eastern end of the great Witwatersrand goldbasin, where a piece of good reef is worked, and a 
mining population has begun to gather. The country is all high, averaging 5000 feet above sea level, and is traversed by ridges which rise some 500 to $\mathrm{I}, 000$ feet more. It is also perfectly bare, except for thorny mimosas scattered here and there, with willows fringing the banks of the few streams.

Great is the contrast when, on reaching Elandsfontein, on the main line of railway, one finds one's self suddenly in the midst of the stir and bustle of industrial life. Here are the tall chimneys of engine-houses; here huge heaps of refuse at the shafts of the mines mark the direction across the country of the great gold-reef. Here, for the first time since he quitted the suburbs of Cape Town, the traveller finds himself again surrounded by a dense population, filled with the eagerness, and feeling the strain and stress, of an industrial life like that of the manufacturing communities of Europe or of North America. Fifteen years ago there was hardly a sign of human occupation. The Boer ranchman sent out his native boys to follow the cattle as they wandered hither and thither, seeking scanty pasturage among the stones, and would have been glad to sell for a hundred pounds the land on which Johannesburg now stands, and beneath which some of the richest mines are worked.

The Witwatersrand (Whitewatersridge) is a rocky ridge rising from one to two or three hundred feet above the level of the adjoining country and running nearly east and west about thirty miles. Along its southern slope the richest reefs or beds containing

B $\mathrm{B} 2$ 
CHAP.

gold (except that near the village of Heidelberg) have been found; but the whole gold-basin, in various parts of which payable reefs have been proved to exist and are being worked, is nearly one hundred and thirty miles long by thirty miles wide. It is called a basin because the various outcropping reefs represent approximately the rim of a basin, and dip to a common centre. But there are many faults which have so changed the positions of the reefs in different places as largely to obliterate the resemblance indicated by the term. It would be impossible to give either a geological account of the district or a practical description of the methods of working without maps and plans and a number of details unsuitable to this book; so I will mention merely a few salient facts, referring the curious reader to the elaborate treatise of Messrs. Hatch and Chalmers, published in 1895 .

The Rand gold-mining district at present consists of a line of mines both east and west of Johannesburg, along the outcrop of the principal reefs. It is about forty-six miles long, but "gold does not occur continuously in payable quantities over that extent, the 'pay-ore' being found in irregular patches, and (less frequently) in well-defined 'pay-shoots' similar to those which characterize quartz-veins." ${ }^{1}$ There are also a few scattered mines in other parts of the basin. On this line there are two principal reefs -the Main Reef, with its so-called "leader," a thin

1 Mr. J. Hays Hammond (the eminent mining engineer) in North American Revieze for February, 1897. 
bed just outside and parallel to it, and the South Reef, with several others which are at present of much less importance. The term "reef" means a bed or stratum of rock, and these Rand reefs are beds of a sort of conglomerate, consisting of sandy and clayey matter containing quartz pebbles. The pebbles are mostly small, from the size of a thrush's egg up to that of a goose's egg, and contain no gold. The arenaceous or argillaceous stuff in which they lie embedded is extremely hard, and strongly impregnated with iron, usually in the form of iron pyrites, which binds it together. It is in this stuff, or sandy and ferreous cement, that the gold occurs. The Boers call the conglomerate "banket" (accented on the last syllable), which is their name for a kind of sweetmeat, because the pebbles lying in the cement are like almonds in the sugary substance of the sweetmeat. The gold is pretty equably diffused in the form of crystals or (less often) of flakescrystals of such extremely small size as to be very rarely visible to the naked eye. Here and there, however, the banket is traversed by thin veins of quartz rock, and nuggets, mostly quite small, are occasionally found in this quartz.

The "Main Reef series" consists of several parallel beds of varying size and thickness, which have not been correlated throughout their entire length; at some points two may be workable; at others three. The Main Reef bed varies from one to twenty feet in thickness; its "leader," which is richer in gold, from three inches to three feet; and 
the South Reef, also generally rich, from three inches to six feet. The Main Reef proper, however, is of too low an ore grade to be profitably worked under present economic conditions, though at two or three mines a percentage of it is milled in conjunction with the richer ore from the other beds.

Where these beds come to the surface, they are inclined, or "dip," as geologists say, at an angle of from $60^{\circ}$ to $30^{\circ}$, and the shafts are now usually sunk to follow the line of dip. But as they are followed down into the earth, the angle diminishes to $30^{\circ}$ or $25^{\circ}$, and it appears certain that at a still greater depth they will be found to lie nearly horizontal. This fact is extremely important, because it promises to make a much larger part of the beds available than would be the case if they continued to plunge downward at a high angle, since in that case they would soon attain a depth at which mining would be impossible, because the heat would be too great, and probably unprofitable also, because the cost of raising the ore would be extremely heavy. At present the greatest depth to which workings have been carried is about 2,400 feet, but skilled engineers think it possible to work as deep as 5,000 feet, though labour becomes more difficult above the temperature of $100^{\circ}$ Fahrenheit, which is reached at 3,000 feet beneath the surface. No difficulty from temperature has been felt at 2,400 feet, and the water is found to give little trouble; indeed a very experienced engineer (to whose 
courtesy I am indebted for these facts) tells me that he thinks most of the water comes from the surface, and can be taken up in the upper levels of the mine which is being worked at the depth mentioned. I have given these details in order to show how enormous a mass of ore remains to be extracted when the deep workings, which are still in their infancy, have been fairly entered upon. But a still more remarkable fact is that the auriferous banket beds appear, so far as they have been followed by deep borings, to retain, as they descend into the earth, not only their average thickness, but also their average mineral quality. Here is the striking feature of the Rand gold-beds, which makes them, so far as we know, unique in the world.

Everywhere else gold-mining is a comparatively hazardous and uncertain enterprise. Where the metal is found in alluvial deposits, the deposits usually vary much in the percentage of gold to the ton of soil which they yield, and they are usually exhausted in a few years. Where it occurs in veins of quartz-rock (the usual matrix), these veins are generally irregular in their thickness, often coming abruptly to an end as one follows them downward, and still more irregular and uncertain in the percentage of gold to rock. For a few yards your quartz-reef may be extremely rich, and thereafter the so-called "shoot" may stop, and the vein contain so little gold as not to pay the cost of working. But in the Witwatersrand basin the precious metal is so uniformly and equally distributed through the 
CHAP.

auriferous beds that when you have found a payable bed you may calculate with more confidence than you can anywhere else that the high proportion or gold to rock will be maintained throughout the bed, not only in its lateral extension, which can be easily verified, but also as it dips downward into the bowels of the earth. It is, therefore, not so much the richness of this gold-field-for the percentage of metal to rock is seldom very high, and the cost of working the hard rock and disengaging the metal from the minerals with which it is associated are heavy items -as it is the comparative certainty of return, and the vast quantity of ore from which that return may be expected, that have made the Rand famous, have drawn to it a great mass of European capital and a large population, and have made the district the object of political desires, ambition, and contests which transcend South Africa and threaten to become a part of the game which the great powers of Europe are playing on the chessboard of the world.

It is believed that the banket or conglomerate beds are of marine origin, but it does not follow that the gold was deposited pari passu with the deposition of the beds, for it may have been-and skilled opinion inclines to this view-carried into the conglomerate seams subsequently to their deposit. In this respect they resemble auriferous veins of quartz, though in these banket reefs the gold-bearing solutions would seem to have come up through the interstitial spaces of the conglomerate instead of in the more or less open fissures of the 
gold-bearing quartz-veins. The chemical conditions under which gold is thus deposited are still conjectural. Gold has long been known to exist in sea-water, in the form of an iodide or a chloride; and one skilful metallurgist at Johannesburg told me that he believed there was as much gold in a cubic mile of sea-water as the whole then annual output of the Rand-that is to say, nearly $£ 8,000,000$.

Had these deposits been discovered a century ago, few, if any of them, would have been worth working, because miners did not then possess the necessary means for extracting the gold from its intractable matrix. It is the progress of chemical science which, by inventing new processes, such as the roasting with chlorine, the treatment in vats with cyanide, and the application of electrical currents, has made the working profitable. Further improvements in the processes of reduction will doubtless increase the mining area, by making it worth while to develop mines where the percentage of metal to rock is now too small to yield a dividend. Improvements, moreover, tend to accelerate the rate of production, and thereby to shorten the life of the mines; for the more profitable working becomes, the greater is the temptation to work as fast as possible and get out the maximum of ore.

The duration of the mines, as a whole, is therefore a difficult problem, for it involves the question whether many pieces of reef, which are now little worked or not worked at all, will in future be found worth working, owing to cheapened appliances and 
to a larger yield of gold per ton of rock, in which case the number of mines may be largely increased, and reefs now neglected be opened up when the present ones have been exhausted. The view of the most competent specialists seems to be that, though many of what are now the best properties will probably be worked out in twenty or thirty years, the district, as a whole, will not be exhausted for at least fifty, and possibly even for seventy or eighty, years to come. And the value of the gold to be extracted within those fifty years has been roughly estimated at not less than $£ 700,000,000$, of which $£ 200,000,000$ will be clear profit, the balance going to pay the cost of extraction. In 1896 the value of the Witwatersrand gold output was $£ 7,400,000{ }^{1}$ Assuming a production of nearly twice that amount, viz., £I $4,000,000$ a year, this would exhaust the field in fifty years; but it is, of course, quite impossible to predict what the future rate of production will be, for that must depend not only on the progress of mechanical and chemical science, but (as we shall presently see) to some extent also upon administrative and even political conditions. In the five years preceding 1896 the production had increased so fast (at the rate of about a million sterling per annum) that, even under the conditions which existed in 1895 , every one expected a further increase, and the product of 1897 will probably be not far short of $£$ io,000,000. With

1 The total output of the California gold deposits up to the

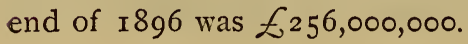


more favourable economic and administrative conditions it might within four years reach $£$ I 4,000,000; and the South African Republic would then stand first among the gold-producing countries. She is now second to the United States only. The total annual output of gold for the whole world was in I 896 about $£ 43,600$, 000 .

Among the economic conditions I have referred to, none is more important than the supply and the wages of labour. On the Rand, as in all South African mines of every kind, unskilled manual labour is performed by Kafirs, whites-together with a few half-breeds and Indian coolies-being employed for all operations, whether within the mine or above the ground, which require intelligence and special knowledge.

The total number of natives employed in 1896 has been given at about 58,000 , and of whites about 6,000. Mr. Hammond (North American Review for February, 1897) puts the Kafirs at 70,000 , receiving nearly $£ 2,500,000$ in annual wages, and the whites at 9,000, receiving over $£^{\mathrm{I}, 800,000 \text {. Whites }}$ would be still more largely employed if they would work harder, but they disdain the more severe kinds of labour, thinking those fit only for Kafirs. The native workmen are of various tribes, Basutos, Zulus, Shanganis, and Zambesi boys being reckoned the best. Most of them come from a distance, some from great distances, and return home when they have saved the sum they need to establish themselves in life. Wages are high, rising for Kafirs to 
$£ 3$ for a lunar month, while white men of course receive much more. The dream of the mine manager is to cut down the cost of native labour by getting a larger and more regular supply, as well as by obtaining cheaper maize to feed the workmen, for at present, owing to the customs duties on foodstuffs, the cost of maize-nearly all of which is imported-is much higher than it need be. So white labour might be much cheapened, while still remaining far better paid than in Europe, by a reduction of the customs tariff, which now makes living inordinately dear. Heavy duties are levied on machinery and chemicals; and dynamite is costly, the manufacture of it having been constituted a monopoly granted to a single person. Of all these things, loud complaints are heard, but perhaps the loudest are directed against the rates of freight levied by the railways, and especially by the Netherlands Company, which owns the lines inside the Transvaal State itself.

Even apart from the question of railway freights, Johannesburg believed in 1895 that better legislation and administration might reduce the cost of production by twenty or thirty per cent., a difference which would of course be rapidly felt in the dividends of the mines that now pay, and which would enable many now unprofitable mines to yield a dividend and many mines to be worked which are now not worth working. ${ }^{1}$

1 The cost of getting the ore has been found in the case of twenty-two upper level companies in the best part of the Rand to 
There is nothing in the natural aspect of the mining belt to distinguish it from the rest of the Transvaal plateau. It is a high, dry, bare, scorched, and windy country, and Johannesburg, its centre, stands in one of the highest, driest, and windiest spots, on the south slope of the Witwatersrand ridge, whose top rises some I5O feet above the business quarters. Founded in 1886 , the town has now a population exceeding 100,000, more than half of them whites. In 1896 the census (probably very imperfect) showed within a radius of three miles 50,000 whites, 42,000 Kafirs, and 6000 Asiatics. Though it is rapidly passing from the stage of shanties and corrugated iron into that of handsome streets lined with tall brick houses, it is still rough and irregular, ill paved, ill lighted, with unbuilt spaces scattered about and good houses set down among hovels.

Another element of unloveliness is supplied by the mines themselves, for the chief reefs run quite close to the southern part of the town, and the huge heaps of "waste rock" or refuse and so-called " tailings," the machinery which raises, crushes, and treats the ore, and the tall chimneys of the enginehouses, are prominent objects in the suburbs. There is not much smoke; but to set against this there is a vast deal of dust, plenty from the streets, and still average twenty-nine shillings and sixpence per ton. A little French book (L'Industrie Minière au Transvaal, published in 1897), which presents a careful examination of these questions, calculates at about thirty per cent. of the expenditure the savings in production which better legislation and administration might render possible. 
CHAP.

more from the tailings and other heaps of highly comminuted ore-refuse. The streets and roads alternate between mud for the two wet months, and dust in the rest of the year; and in the dry months not only the streets but the air is full of dust, for there is usually a wind blowing. But for this dust, and for the want of proper drainage and a proper water-supply, the place would be healthy, for the air is dry and bracing. But there had been up to the end of 1895 a good deal of typhoid fever. and a great deal of pneumonia, often rapidly fatal. In the latter part of 1896 the mortality was as high as 58 per thousand. ${ }^{1}$

It is a striking contrast to pass from the business part of the town to the pretty suburb which lies to the north-east under the steep ridge of the Witwatersrand, where the wealthier residents have erected charming villas and surrounded them with groves and gardens. Less pretty, but far more striking, is the situation of a few of the outlying country houses which have been built to the north, on the rocky top or along the northern slope of the same ridge. These have a noble prospect over thirty or forty miles of rolling country to the distant Magaliesberg. East and west the horizon is closed by long ranges of blue hills, while beneath, some large plantations of trees, and fields cultivated by irrigation, give to the landscape a greenness rare in this arid land. Standing on this lonely height

1 There are towns in England where the rate is only i 3 per thousand. 
and looking far away towards the Limpopo and Bechuanaland, it is hard to believe that such a centre of restless and strenuous life as Johannesburg is so near at hand. The prospect is one of the finest in this part of Africa; and it is to be hoped that a tract on these breezy heights will, before building has spread further, be acquired by the town as a public park.

Though in its general aspect Johannesburg comes nearer to one of the new mining cities of western America than to any place in Europe, yet in many points it is more English than American, as it is far more English than Dutch. Indeed, there is nothing to remind the traveller that he is in a Dutch country except the Dutch names of the streets on some of the street corners. The population-very mixed, for there are Germans, Italians, and French, as well as some natives of India-is practically Englishspeaking, for next in number to the colonial English and the recent immigrants from Great Britain come the Australians and the Americans, who are for all social purposes practically English. It is a busy, eager, restless, pleasure-loving town, making money fast and spending it lavishly, filled from end to end with the fever of mining speculation. This pursuit concentrates itself in one spot where two of the principal streets meet, and where a part of one of them is inclosed within low chains, so as to make a sort of inclosure, in which those who traffic in gold shares meet to buy and sell. "Between the chains" is the local expression for the mining exchange, or 
share-market, and a sensitive and unstable market it is. It had been "booming" for most of the year, and many stocks stood far too high. But while we were there what is called a "slump" occurred, and it was pretty to study the phenomenon on the countenances between the chains.

The passion of the people for sport, and especially for racing, is . characteristically English. The gambling-saloon is less conspicuous than in Transatlantic mining-camps, and there are far fewer breaches of public order. Decorum is not always maintained. When I was there, a bout of fisticuffs occurred between the ex-head of the town police and his recently appointed successor, and the prowess of the former delighted a large ring of English spectators who gathered round the combatants. But one hears of no shootings or lynchings; and considering the great number of bad characters who congregate at places of this kind, it was surprising that the excess of crime over other South African towns (in which there is very little crime among the whites) should not have been larger. Partly, perhaps, because the country is far from Europe, the element of mere roughs and rowdies, of scalawags, hoodlums, and larrikins, is comparatively small, and the proportion of educated men unusually large. The best society of the place -of course not very numerous-is cultivated and agreeable. It consists of men of English or AngloJewish race-including Cape Colonists and Americans, with a few Germans, mostly of Jewish origin. 
I should conjecture the English and colonial element to compose seven-tenths of the white population, the American and German about one-tenth each, while Frenchmen and other European nations make up the residue. There are hardly any Boers or Hollanders, except government officials; and one feels one's self all the time in an English, that is to say, an Anglo-Semitic town. Though there are 45,000 Kafirs, not many are to be seen about the streets. The Boer farmers of the neighbourhood drive their waggons in every morning, laden with vegetables. But there are so few of the native citizens of the South African Republic resident in this its largest town that the traveller cannot help fancying himself in the Colony; and it was only natural that the English-speaking people, although newcomers, should feel the place to be virtually their own.

Great is the change when one passes from the busy Johannesburg to the sleepy Pretoria, the political capital of the country, laid out forty-three years ago, and made the seat of government in 1863. The little town-it has about 12,000 inhabitants, two-thirds of whom are whites-lies in a warm and well-watered valley about thirty miles N.N.E. of Johannesburg. The gum-trees and willows that have grown up swiftly in the gardens and along the avenues embower it: and the views over the valley from the low hills-most of them now (since the middle of 1896 ) crowned by batteries of cannon-that rise above the suburbs are pleasing. But it has neither the superb panoramic prospect 
nor the sense of abounding wealth and strenuous life that make Johannesburg striking. The streets are wide, and after rain so muddy as to be almost impassable ; the houses irregular, yet seldom picturesque. Nothing could be less beautiful than the big Dutch church which occupies the best situation, in the middle of the market square. There is, however, one stately and even sumptuous building, that which contains the Government Offices and chambers of the legislature. It is said to have cost $£ 200,000$. The room in which the Volksraad (i.e., the First or chief Volksraad) meets is spacious and handsome. It interests the visitor to note that on the right hand of the chair of the presiding officer there is another chair, on the same level, for the President of the Republic, while to the right there are seats for the five members of the Executive Council, and to the left five others for the heads of the administrative departments, though none of these eleven is a member of the Raad.

We had expected to find Pretoria as Dutch as Johannesburg is English. But although there is a considerable Boer and Hollander population, and one hears Dutch largely spoken, the general aspect of the town is British-colonial; and the Britishcolonial element is conspicuous and influential. Having little trade and no industry, Pretoria exists chiefly as the seat of the administration and of the courts of law. Now the majority of the bar are British-colonials from Cape Colony or England. The large interests involved in the gold-fields, and 
the questions that arise between the companies formed to work them, give abundant scope for litigation, and one whole street, commonly known as the Aasvogelsnest (Vulture's Nest), is filled with their offices. They and the judges, the most distinguished of whom are also either colonial Dutchmen or of British origin, are the most cultivated and (except as regards political power) the leading section of society. It is a real pleasure to the European traveller to meet so many able and wellread men as the bench and bar of Pretoria contain ; and he finds it odd that many of them should be excluded from the franchise and most of them regarded with suspicion by the ruling powers. Johannesburg (with its mining environs) has nearly all the industry and wealth, and half the whole white population of the Transvaal-a country, be it remembered, as large as Great Britain. Pretoria and the lonely country to the north, east, and west ${ }^{1}$ have the rest of the population and all the power. It is true that Pretoria has also a good deal of the intelligence. But this intelligence is frequently dissociated from political rights.

President Kruger lives in a house which the Republic has presented to him, five minutes' walk from the public offices. It is a long, low cottage, like an Indian bungalow, with nothing to distinguish it from other dwellings. The President has, how-

1 There are some mines of gold and coal in other parts, mostly on the east side of the country, with a small industrial population consisting chiefly of recent immigrants. 
ever, a salary of $£ 7$,000 a year, besides an allowance, commonly called "coffee money," to enable him to defray the expenses of hospitality. Just opposite stands the little chapel of the so-called Dopper sect in which he occasionally preaches. Like the Scotch of former days, the Boers have generally taken more interest in ecclesiastical than in secular politics. A sharp contest has raged among them between the party which desires to be in full communion with the Dutch Reformed Church of Cape Colony and the party which prefers isolation, distrusting (it would seem unjustly) the strict orthodoxy of that church. The Doppers are still more stringent in their adherence to ancient ways. When I asked for an account of their tenets, I was told that they wore long waistcoats and refused to sing hymns. They are, in fact, old-fashioned Puritans in dogmatic beliefs and social usages, and, as in the case of the more extreme Puritans of the seventeenth century, this theological stringency is accompanied by a firmness of character which has given them a power disproportionate to their numbers.

Quiet as Pretoria is, the echoes of the noisy Rand are heard in it, and the Rand questions occupy men's minds. But outside Pretoria the country is lonely and silent, like all other parts of the Transvaal, except the mining districts. Here and there, at long intervals, you come upon a cluster of houses -one can hardly call them villages. If it were not for the mines, there would not be one white man to a square mile over the whole Republic. 


\section{CHAPTER XIX}

THE ORANGE FREE STATE

In the last preceding chapter I have carried the reader into the Transvaal through Natal, because this is the most interesting route. But most travellers in fact enter via Cape Colony and the Orange Free State, that State lying between the north-eastern frontier of the Colony and the southeastern frontier of the Transvaal. Of the Free State there is not much to say; but that little needs to be said, because this Republic is a very important factor in South African politics, and before coming to its politics, the reader ought to know something of its population. I have already (Chapter V.) summarised its physical features and have referred (Chapter XI.) to the main incidents in its history. Physically, there is little to distinguish it from the regions that bound it to the east, north, and west. Like them, it is level or undulating, dry, and bare-in the main a land of pasture. One considerable diamond mine is worked in the west, and along the banks of the Caledon River there lies one rich agricultural district. But 
the land under cultivation is less than one per cent. of the whole area. There are no manufactures, and of course very little trade; so the scanty population increases slowly. It is a country of great grassy plains, brilliantly green and fresh after rain has fallen, parched and dusty at other times, but able to support great numbers of cattle and sheep. Rare farm-houses and still rarer villages are scattered over this wide expanse, which, in the northeast, toward Natal, rises into a mountainous region. The natives (most of them of Bechuana stock) are nearly twice as numerous as the whites. Some live on a large Barolong reservation, where they till the soil and keep their cattle in their own way. The rest are scattered over the country, mostly employed as herdsmen to the farmers. Save on the reservation, they cannot own land or travel without a pass, and of course they are not admitted to the electoral franchise. They seem, however, to be fairly well treated, and are perfectly submissive. Their wages average thirty shillings a month. Native labour has become so scarce that no farmer is now permitted to employ more than twenty-five. Of the whites, fully two-thirds are of Dutch origin, and Dutch is pretty generally spoken. English, however, is understood by most people, and is the language most commonly used in the larger villages. The two races have lived of late years in perfect harmony, for there has never been any war between the Free State and Great Britain. As the tendency of the English citizens to look to Cape 
Colony has been checked by the sentiment of independence which soon grew up in this little Republic, and by their attachment to its institutions, so the knowledge of the Dutch citizens that the English element entertains this sentiment and attachment has prevented the growth of suspicion among the Dutch, and has knitted the two races into a unity which is generally cordial. ${ }^{1}$ Nevertheless, so much Dutch feeling remains, that at the recent election of a President the scale was decisively turned in favour of one out of the two candidates, both able and experienced men, by the fact that the one belonged to a Dutch, the other to a Scottish family. It may be added that the proximity of the Colony, and the presence of the large English element, have told favourably upon the Dutch population in the way of stimulating their intelligence and modifying their conservatism, while not injuring those solid qualities which make them excellent citizens. The desire for instruction is far stronger among them than it is in the Transvaal. Indeed, there is no part of South Africa where education is more valued and more widely diffused.

The only place that can be called a town is Bloemfontein, the seat of government, which stands on the great trunk-line of railway from Cape Town to Pretoria, seven hundred and fifty miles from the former and two hundred and ninety from the latter

1 Mr. Brand was chosen President when practising law in Cape Colony; and afterwards accepted, with the full assent of his citizens, a British order of knighthood. 
CHAP.

town. It is what the Germans call a "freundliches Städtchen," a bright and cheerful little place with 3,300 white and 2,500 black inhabitants, nestling under a rocky kopje, and looking out over illimitable plains to the east and south. The air is dry and bracing, and said to be especially beneficial to persons threatened with pulmonary disease. As it is one of the smallest, so it is one of the neatest and, in a modest way, best appointed capitals in the world. It has a little fort, originally built by the British Government, with two Maxim guns in the arsenal, a Protestant Episcopal and a Roman Catholic cathedral as well as Dutch Reformed churches, all kinds of public institutions, a spacious market square, with a good club and an excellent hotel, wide and well-kept streets, gardens planted with trees that are now so tall as to make the whole place seem to swim in green, a national museum, and a very handsome building for the legislature, whose principal apartment is as tasteful, well lighted, and well arranged as any I have seen in any British Colony or American State. The place is extremely quiet, and people live very simply, though not cheaply, for prices are high, and domestic service so dear and scarce as to be almost unprocurable. Every one is above poverty, but still further removed from wealth. It looks, and one is told that it is, the most idyllic community in Africa, worthy to be the capital of this contented and happy State. No great industries have come into the Free State to raise economic strife. No capitalists tempt the virtue of 
legislators, or are forced to buy off the attacks of blackmailers. No religious animosities divide Christians, for there is perfect religious freedom. No difficulties as to British suzerainty exist, for the Republic is absolutely independent. No native troubles have arisen. No prize is offered to ambition. No political parties have sprung up. Taxation is low, and there is no public debt. ${ }^{1}$ The arms of the State are a lion and a lamb standing on opposite sides of an orange-tree with the motto, "Freedom, Immigration, Patience, Courage," and though the lion has, since $187 \mathrm{I}$, ceased to range over the plains, his pacific attitude beside the lamb on this device happily typifies the harmony which exists between the British and Dutch elements, and the spirit of concord which the late excellent President Brand so well infused into the public life of his Republic. In the Orange Free State I discovered, in 1895 , the kind of commonwealth which the fond fancy of the philosophers of last century painted. It is an ideal commonwealth, not in respect of any special excellence in its institutions, but because the economic and social conditions which have made democracy so far from an unmixed success in the American States and in the larger colonies of Britain, not to speak of the peoples of Europe, whether ancient or modern, have not come into

1 Strictly speaking, there is a debt of about twenty thousand pounds; but the State is paying it off by drawings, and would pay it off altogether at once did not the market price stand too high. 
existence here, while the external dangers which for a time threatened the State have, years ago, vanished away like clouds into the blue.

Although, however, the political constitution of the Free State is not the chief cause of the peace and order which the State enjoys, it may claim to be well suited to the community which lives happily under it. It is a simple constitution, and embodied in a very short, terse, and straightforward instrument of sixty-two articles, most of them only a few lines in length.

The governing authorities are the President, the Executive Council, and the Volksraad or elective popular assembly. Citizenship belongs to all white persons born in the State, or who have resided in it for three years and have made a written promise of allegiance, or have resided one year and possess real property of the value of one hundred and fifty pounds sterling, a liberality which is in marked contrast to the restrictions imposed upon newcomers by the laws of the Transvaal. Thus, practically, all the male white inhabitants are citizens, with full rights of suffrage-subject to some small property qualifications for newcomers which it is hardly worth while to enumerate.

The President is elected by the citizens for five years and is re-eligible. He can sit and speak but cannot vote in the Volksraad, is responsible to it, and has the general control of the administration.

The Executive Council consists of five members -besides the President-viz., the State Secretary 
and the Magistrate of Bloemfontein, both of whom are appointed by the President and confirmed by the Volksraad, and three other members chosen by the Volksraad. It is associated with the President for divers purposes, but has not proved to be an important or influential body.

The Volksraad is elected by all the citizens for four years, half of the members retiring every two years. It has only one chamber, in which there sit at present fifty-eight members. It is the supreme legislative authority, meeting annually, and in extra sessions when summoned, and its consent is required to the making of treaties and to a declaration of war. The President has no veto on its acts, and the heads of the executive departments do not sit in it.

The obligation of military service is universal on all citizens between the ages of sixteen and sixty.

The constitution can be altered by the Volksraad, but only by a three-fourths majority in two consecutive annual sessions. It is therefore a Rigid constitution, like that of the United States and that of Switzerland.

This simple scheme of government seems calculated to throw nearly all power in the hands of the legislature, leaving the President comparatively weak. Nevertheless, in point of fact the Presidents have been very important figures, partly because there have been no parties in the legislature, and therefore no party leaders. From 1863 till his death in 1888 , the whole policy of the State was 
CHAP.

guided by President Brand, a lawyer from the Cape, whom the people elected for five successive terms. His power of sitting in and addressing the Volksraad proved to be of the utmost value, for his judgment and patriotism inspired perfect confidence. His successor, who at the time of my visit (November, I 895) had just been obliged by ill-health to retire from office, enjoyed equal respect, and, when he chose to exert it, almost equal influence with the legislature, and things went smoothly under him. I gather that the new President, Judge Steyn, elected in 1896 , is similarly respected for his character and abilities, and is likely to enjoy similar weight. So the Speaker of the legislature has been an influential person, because his office devolves upon him functions which the absence of a Cabinet makes important. The fact is that in every government, give it what form you please, call it by what name you will, individual men are the chief factors, and if the course of things is such that the legislature does not become divided into parties and is not called on to produce conspicuous leaders, general leadership will fall to the executive head if he is fit to assume it, and legislative leadership to the chairman of the assembly. Were questions to arise splitting up the people and the legislature into factions, the situation would change at once. Oratorical gifts and legislative strategy would become valuable, and the President or the Speaker of the assembly might be obscured by the chiefs of the parties. 
The people of the Free State are well satisfied with their constitution, and show little disposition to alter it. Some of the wisest heads, however, told me that they thought two improvements were needed: a provision that amendments to the constitution, after having passed the Volksraad, should be voted on by the people (as in the Swiss Referendum), and a provision securing to the judges their salaries, and their independence of the Volksraad. It is interesting to notice that both here and in the Transvaal the gravest constitutional questions that have arisen turn on the relations between the legislative and the judicial departments. Some years ago the Free State Volksraad claimed the right to commit a person to prison for contempt, and to direct the State attorney to prosecute him. The Chief Justice, a distinguished lawyer, and his colleagues felt bound to resist what they thought an unconstitutional stretch of power by the Raad. At first they seemed likely to be defeated, but by using their opportunities of charging juries to insist on their views they brought public opinion round to their side, and the Raad ultimately retired from the position it had taken up, leaving the question of right undetermined. It has never been definitely settled whether the courts of law are (as in the United States) the authorized interpreters of the constitution, though upon principle it would seem that they are. These South African constitutions were drafted by simple men in an untechnical way, so that many legal points obvious to the minds of English 
or American lawyers were left untouched, and have now to be settled either on principle or according to the will of what may happen to be the predominant power for the time being. It is, perhaps, better that they should remain in abeyance until public opinion has grown more instructed and has had fuller opportunities of considering them.

Small as is the white population of the Orange Free State, its geographical position and the high average quality of its citizens secure for it a position of great significance in South African politics; and the attitude it might take would be an important factor in any dispute between the British Government and the Transvaal Republic. The troubles of December, 1895, drew it nearer to the Transvaal, for the Free State Boers have strong political sympathy with their northern kinsfolk. They are, however, far from approving the policy of mere resistance to reform which President Kruger has taken up; and would, I think, hesitate to support the Transvaal in any course at variance with its present treaty engagements. To this topic I may have occasion presently to return. Meanwhile I pass on to describe the native State which lies nearest to it, which has been most closely connected with its fortunes, and which in one respect furnishes a parallel to it, having been of late years the most quiet and contented among native communities. 


\section{CHAPTER XX}

\section{BASUTOLAND}

BASUTOLAND is a comparatively small territory (I, 300 square miles) somewhat larger than Wales or Massachusetts. It is nearly all mountainous, and contains the highest summits in South Africa, some of them reaching II,O0O feet. Few European travellers visit it, for it lies quite away from the main routes; it has no commercial importance, and its white population is extremely small, the land being reserved for the natives alone. We were attracted to it by what we had heard of the scenery; but found, when we came to traverse it, that the social conditions were no less interesting than the landscapes.

The easiest approach is from Bloemfontein. Starting from that pleasant little town one bright November morning on the top of the Ladybrand coach, we drove over wide and nearly level stretches of pasture-land, which now, after the first rains, were vividly green, and beginning to be dotted with flowers. The road was only a track, rough and full of ruts, and the coach, drawn by eight horses, was an 
old one, whose springs had lost whatever elasticity they might once have possessed, so that it was only by holding tight on to the little rail at the back of the seat that we could keep our places. The incessant pitching and jolting would have been intolerable on an ordinary drive ; but here the beauty of the vast landscape, the keen freshness of the air, and the brilliance of the light made one forget every physical discomfort. About noon, after crossing the muddy flood of the Modder River, whose channel, almost dry a month before, had now been filled by the rains, we entered a more hilly region, and came soon after noon to the village of Thaba 'Ntshu, called from the bold rocky peak of that name, which is a landmark for all the country round, and is famous in history as the rallying-point of the various parties of emigrant Boers who quitted Cape Colony in the Great Trek of $1836-37$. Near it is a large native reservation, where thousands of Barolong Kafirs live, tilling the better bits of soil, and grazing their cattle all over the rolling pastures. Some ten or fifteen miles farther the track reaches the top of a long ascent, and a magnificent prospect is revealed to the south-east of the noble range of the Maluti Mountains, standing out in the dazzling clearness of this dry African air, yet mellowed by distance to tints of delicate beauty. We were reminded of the view of the Pyrenees from Pau, where, however, the mountains are both nearer and higher than here, and of the view of the Rocky Mountains from Calgary, on the Canadian Pacific Railway. From 
this point onward the road mounts successive ridges, between which lie rich hollows of agricultural land, and from the tops of which nearer and nearer views of the Maluti range are gained. There was hardly a tree visible, save those which Europeans have planted round the farm-houses that one finds every seven or eight miles; and I dare say the country would be dreary in the dry season or in dull grey weather. But as we saw it, the wealth of sunlight, the blue of the sky above, the boundless stretches of verdure beneath, made the drive a dream of delight. When the sun sank the constellations came out in this pure, dry African air with a brilliance unknown to Europe ; and we tired our eyes in gazing on the Centaur and the Argo and those two Magellanic clouds by which one finds the position of the southern pole. Soon after dark we came to the top of the last high hill, and saw what seemed an abyss opening beneath. The descent was steep, but a beaten track led down it, reputed the most dangerous piece of road in the Free State; and the driver regaled us with narratives of the accidents that had taken place on the frequent occasions when the coach had been upset, adding, however, that nobody ever had been or would be killed while he held the reins. He proved as good as his word, and brought us safely to Ladybrand at 9 P.M., after more than twelve hours of a drive so fatiguing that only the marvellously bracing air enabled us to feel none the worse for it.

Ladybrand is a pretty little hamlet lying at the 
foot of the great flat-topped hill, called the Plaat Berg, which the perilous road crosses, and looking out from groves of Australian gum-trees, across fertile corn-fields and meadows, to the Caledon River and the ranges of Basutoland. A ride of eight miles brings one to the ferry (which in the dry season becomes a shallow ford) across this stream, and on the farther shore one is again under the British flag at Maseru, the residence of the Imperial Commissioner who supervises the administration of the country, under the direction of the High Commissioner for South Africa. Here are some sixty Europeans-officials, police, and storekeepers-and more than two thousand natives. Neither here nor anywhere else in Basutoland is there an inn; those few persons who visit the country find quarters in the stores which several whites have been permitted to establish, unless they have, as we had, the good fortune to be the guests of the Commissioner.

Basutoland is the Switzerland of South Africa. and, very appropriately, is the part of South Africa where the old inhabitants, defended by their hills, have retained the largest measure of freedom. Although most of it is covered with lofty mountains, it has, like Switzerland, one comparatively level and fertile tract-that which lies along the left bank of the Caledon River. Morija, the oldest French mission station, lies in a pretty hollow between five and six thousand feet above the sea,-nearly all Basutoland is above 5,000 feet,--some sixteen miles 
south-east from Maseru. Groves of trees and luxuriant gardens give softness and verdure to the landscape, and among them the mission houses and schools, and printing-house whence Basuto books are issued, lie scattered about, up and down the slopes of the hill. Though there are plenty of streams in Basutoland, there is hardly any swampy ground, and consequently little or no fever, so the missionaries invalided from the Zambesi frequently come here to recruit. Morija is now, and has been for many years past, in the hands of Scottish Presbyterian clergymen, of course under the direction of the Paris Society, and they gave us a hearty welcome. They have large and flourishing schools, from which a considerable number of young Kafirs go out every year among their countrymen and become an effective civilizing influence. There is among the Bantu tribes so little religion, in the European sense of the word, that the natives seem never to have felt the impulse to persecute, and hardly ever to obstruct the preaching of Christianity. When opposition comes, it comes from the witchdoctor or medicine-man, who feels his craft in danger, seldom from the chief. Here most of the leading men have been and still are on good terms with the missionaries. The Paramount Chief of the whole country lives three miles from Morija, at Matsieng, where he has established, as the wont of the Kafirs is, a new kraal on the top of a breezy hill, forsaking the residence of his father in the valley beneath. Here we visited him. 
Lerothodi, the Paramount Chief, is the son of Letsie and grandson of Moshesh, and now ranks with Khama as the most important native potentate south of the Zambesi. He is a strong, thick-set man, who looks about fifty years of age, and is not wanting either in intelligence or in firmness. $\mathrm{He}$ was dressed in a grey shooting-coat and trousers of grey cloth, with a neat new black, low-crowned hat, and received the Deputy Acting Commissioner and ourselves in a stone house which he has recently built as a sort of council-chamber and reception-room for white visitors. Hard by, another house, also of stone, was being erected to lodge such visitors, and over its doorway a native sculptor had carved the figure of a crocodile, the totem of the Basutos. When a chief sits to administer justice among the tribesmen, as he does on most mornings, he always sits in the open air, a little way from his sleepinghuts. We found a crowd of natives gathered at the levee, whom Lerothodi quitted to lead us into the reception-room. He was accompanied by six or seven magnates and counsellors,- - one of the most trusted counsellors (a Christian) was not a person of rank, but owed his influence to his character and talents,-and among these one spoke English and interpreted to us the compliments which Lerothodi delivered, together with his assurances of friendship and respect for the Protecting Power, while we responded with phrases of similar friendliness. The counsellors, listening with profound and impressive gravity, echoed the sentences of the chief 
with a chorus of "ehs," a sound which it is hard to reproduce by letters, for it is a long, slow, deep expiration of the breath in a sort of singing tune. The Kafirs constantly use it to express assent and appreciation, and manage to throw a great deal of apparent feeling into it. Presently some of them spoke, one in pretty good English, dilating on the wish of the Basuto ${ }^{1}$ tribe to be guided in the path of prosperity by the British Government. Then Lerothodi led us out and showed us, with some pride, the new guest-house he was building, and the huts inhabited by his wives, all scrupulously neat. Each hut stands in an inclosure surrounded by a tall fence of reeds, and the floors of red clay were perfectly hard, smooth, and spotlessly clean. The news of the reception accorded shortly before (in London) to Khama had kindled in him a desire to visit England, but his hints thrown out to that effect were met by the Commissioner's remark that Khama's total abstinence and general hostility to the use of intoxicants had been a main cause for the welcome given him, and that if other chiefs desired like treatment in England they had better emulate Khama. This shot went home.

From the chief's kraal we had a delightful ride of some twenty miles to a spot near the foot of the high mountains, where we camped for the night. The track leads along the base of the Maluti range,

1 The word "Ba Sot'ho" is in strictness used for the people, "Se Sot'ho" for the language, "Le Sot'ho" for the country; but in English it is more convenient to apply "Basuto" to all three. 
CHAP.

sometimes over a rolling table-land, sometimes over hills and down through valleys, all either cultivated or covered with fresh close grass. The Malutis consist of beds of sandstone and shale, overlaid by an outflow of igneous rock from two to five thousand feet thick. They rise very steeply, sometimes breaking into long lines of dark brown precipice, and the crest seldom sinks lower than 7,000 feet. Behind them to the south-east are the waterfalls, one of which, 630 feet high, is described as the grandest cascade in Africa south of the Zambesi. It was only two days' journey away, but unfortunately we had not time to visit it.

The country we were traversing beneath the mountains was full of beauty, so graceful were the slopes and rolls of the hills, so bright the green of the pastures; while the sky, this being the rainy season, had a soft tone like that of England, and was flecked with white clouds sailing across the blue. It was also a prosperous-looking country, for the rich soil supported many villages, and many natives, men as well as women, were to be seen at work in the fields as we rode by. Except where streams have cut deeply into the soft earth, one gets about easily on horseback, for there are no woods save a little scrub clinging to the sides of the steeper glens. We were told that the goats eat off the young trees, and that the natives have used the older ones for fuel. In the afternoon we passed St. Michael's, the seat of a flourishing Roman Catholic mission, and took our way up the steep and stony track of 
a kloof (ravine) which led to a plateau some 6,000 feet or more above sea-level. The soil of this plateau is a deep red loam, formed by the decomposition of the trap-rock, and is of exceptional fertility, like the decomposed traps of Oregon and of the Deccan. Here we pitched our tent, and found our liberal supply of blankets none too liberal, for the air was keen, and the difference between day and night temperature is great in these latitudes. Next morning, starting soon after dawn, we rode across the deep-cut beds of streams and over breezy pastures for some six or seven miles, to the base of the main Maluti range, and after a second breakfast prepared for the ascent of the great summit, which we had been admiring for two days as it towered over the long line of peaks or peered alone from the mists which often enveloped the rest of the range. It is called Machacha, and is a conspicuous object from Ladybrand and the Free State uplands nearly as far as Thaba 'Ntshu. Our route lay up a grassy hollow so steep that we had thought our friend, the Commissioner, must be jesting when he pointed up it and told us that was the way we had to ride. For a pedestrian it was a piece of hand and foot climbing, and seemed quite impracticable for horses. But up the horses went. They are a wonderful breed, these little Basuto nags. This region is the part of South Africa where the horse seems most thoroughly at home and happy, and is almost the only part where the natives breed 
and ride him. Sixty years ago there was not a horse in the country-the animal, it need hardly be said, is not a native of South Africa. But by 1852 , the Basutos had plenty of ponies, and used them in the short campaign of that year with extraordinary effect. They are small, seldom excceding twelve hands in height, a little larger than the ponies of Iceland, very hardy, and wonderfully clever on hills, able not only to mount a slope whose angle is $30^{\circ}$ to $35^{\circ}$, but to keep their footing when ridden horizontally along it. A rider new to the country finds it hard not to slip off over the tail when the animal is ascending, or over the head when he is descending.

The hollow brought us to a col fully 7,500 feet above the sea, from which we descended some way into a valley behind, and then rode for three or four miles along the steep sides, gradually mounting, and having below us on the right a deep glen, covered everywhere with rich grass, and from the depths of which the murmur of a rushing stream, a sound rare in South Africa, rose up softly through the still, clear air. At length we reached the mountain crest, and after following it for a space, and then, to avoid the crags along the crest, guiding our horses across the extremely steep declivities by which it sinks to the east, came to a pass between precipices, with a sharp rock towering up in the middle of it and a glen falling abruptly to the west. Beyond this point $-8,500$ feet or so above sea-level-the slopes were too steep even 
for the Basuto horses, and we therefore left them in charge of one of our Kafir attendants. A more rich and varied alpine flora than clothed the pastures all round I have seldom seen. The flowers had those brilliant hues that belong to the plants of our high European mountains, and they grew in marvellous profusion. They were mostly of the same genera as one finds in the Alps or the Pyrenees, but all or nearly all of different species ; and among those I found several, particularly two beautiful Gerania, which the authorities at Kew have since told me are new to science. It was interesting to come here upon two kinds of heath-the first we had seen since quitting the Cape peninsula, for, rich as that peninsula is in heaths, there are very few to be found in other parts of South Africa, and those only, I think, upon high mountains.

After a short rest we started for the final climb, first up a steep acclivity, covered with low shrubs and stones, and then across a wide hollow, where several springs of deliciously cold water break out. Less than an hour's easy work brought us to the highest point of a ridge which fell northward in a precipice, and our Kafirs declared that this was the summit of Machacha. But right in front of us, not half a mile away, on the other side of a deep semicircular gulf,-what is called in Scotland a corrie,a huge black cliff reared its head 400 feet above us, and above everything else in sight. This was evidently the true top, and must be ascended. The Kafirs, perhaps thinking they had done enough for 
CHAP.

one day, protested that it was inaccessible. "Nonsense," we answered; "that is where we are going " ; and when we started off at full speed they followed. Keeping along the crest for about half a mile to the eastward-it is an arête which breaks down to the corrie in tremendous precipices, but slopes more gently to the south-we came to the base of the black cliff, and presently discovered a way by which, climbing hither and thither through the crags, we reached the summit, and saw an immense landscape unroll itself before us. It was one of those views which have the charm, so often absent from mountain panoramas, of combining a wide stretch of plain in one direction with a tossing sea of mountain-peaks in another. To the northeast and east and south-east, one saw nothing but mountains, some of them, especially in the far north-east, toward Natal, apparently as lofty as that on which we stood, and many of them built on bold and noble lines. To the south-east, where are the great waterfalls which are one of the glories of Basutoland, the general height was less, but a few peaks seemed to reach 10,000 feet. At our feet, to the west and south-west, lay the smiling corn-fields and pastures we had traversed the day before, and beyond them the rich and populous valley of the Caledon River, and beyond it, again, the rolling uplands of the Orange Free State, with the peak of Thaba 'Ntshu just visible, and still farther a blue ridge, faint in the extreme distance, that seemed to lie on the other side of Bloemfontein, nearly one 
hundred miles away. The sky was bright above us, but thunderstorms hung over the plains of the Free State behind Ladybrand, and now and then one caught a forked tongue of light flashing from among them. It was a magnificent landscape, whose bareness-for there is scarcely a tree upon these slopes-was more than compensated by the brilliance of the light and the clearness of the air, which made the contrast between the sunlit valley of the Caledon and the solemn shadows under the thunder-clouds more striking, and the tone of the distant ranges more deep and rich in colour, than in any similar prospect one could recall from the mountain watch-towers of Europe. Nor was the element of historical interest wanting. Fifteen miles away, but seeming to lie almost at our feet, was the flat-topped hill of Thaba Bosiyo, the oftbesieged stronghold of Moshesh, and beyond it the broad table-land of Berea, where the Basutos fought, and almost overcame, the forces of Sir George Cathcart in that war of 1852 which was so fateful both to Basutoland and to the Free State.

Less than a mile from the peak on which we sat, we could descry, in the precipice which surrounds the great corrie, the black mouth of a cave. It was the den of the cannibal chief Machacha, whose name has clung to the mountain, and who established himself there seventy years ago, when the ravages of Tshaka, the Zulu king, had driven the Kafir tribes of Natal to seek safety in flight, and reduced some among them, for want of other food, 
CHAP.

to take to human flesh. Before that time this mountain-land had been inhabited only by wandering Bushmen, who have left marks of their presence in pictures on the rocks. Here and there among the crags jabbering baboons darted about, and great hawks sailed in circles above us. Otherwise we had seen no living wild creature since we left the pastures of the valley.

The summit of Machacha is composed of a dark igneous rock, apparently a sort of amygdaloidal trap, with white and greenish calcareous crystals scattered through it. The height is given on the maps as I I,, 00 feet ; but so far as one could judge by frequent observations from below and by calculations made during the ascent, I should think it not more than 10,500 . It seems to be the culminating point of the Maluti range, but may be exceeded in height by Mont aux Sources, eighty miles off to the northeast, where Basutoland touches Natal on the one side and the Free State on the other.

Descending by a somewhat more direct route, which we struck out for ourselves, we rejoined our horses at the pass where we had left them three hours before, and from there plunged down the kloof, or ravine, between the precipices which lead to the foot of the mountain. It was here too steep to ride; indeed, it was about as steep a slope as one can descend on foot with comfort, the angle being in some places fully $40^{\circ}$. A grand piece of scenery, for the dark rock walls rose menacing on either hand; and also a beautiful one, for the flowers, 
especially two brilliant shrubby geraniums, were profuse and gorgeous in hue. At the bottom, after a very rough scramble, we mounted our horses and hastened along to escape the thunderstorm which was now nearly upon us, and which presently drove us for shelter into a native hut, where a Basuto woman, with her infant hanging in a cloth on her back, was grinding corn between two stones. She went on with her work, and presently addressed my wife, asking (as was explained to us) for a piece of soap wherewith to smear her face, presumably as a more fragrant substitute for the clay or ochre with which the Basuto ladies cover their bodies. The hut was clean and sweet, and, indeed, all through Basutoland we were struck by the neat finish of the dwellings and of the reed fences which inclose them. When the storm had passed away over the mountains, "growling and muttering into other lands," and the vast horizon was again flooded with evening sunshine, we rode swiftly away, first over the rolling plateau we had traversed in the forenoon, then turning to the north along the top of the sandstone cliffs that inclose the valley of the Kaloe River, where Bushman pictures adorn the caves. At last as night fell, we dropped into the valley of the Kaloe itself, and so slowly through the darkness, for the horses were tired, and the track (which crosses the river four times) was rough and stony, came at last to the mission station of Thaba Bosiyo. Here we were welcomed by the Swiss pastor in charge of the mission, Mr. E. Jacottet, whose 
CHAP.

collection of Basuto and Barotse popular tales have made him well known to the students of folk-lore. No man knows the Basutos better than he and his colleague, Mr. Dyke of Morija ; and what they told us was of the highest interest. Next day was Sunday, and gave us the opportunity of seeing a large congregation of Basuto converts and of hearing their singing, the excellence of which reminded us of the singing of negro congregations in the Southern States of America. We had also two interesting visits. One was from an elderly Basuto magnate of the neighbourhood, who was extremely anxious to know if Queen Victoria really existed, or was a mere figment of the British Government. He had met many white men, he told us, but none of them had ever set eyes on the Queen, and he could not imagine how it was possible that a great chieftainess should not be seen by her people. $\mathrm{W}^{\top} \mathrm{e}$ satisfied his curiosity by giving full details of the times, places, and manner in which the British sovereign receives her subjects, and he went away, declaring himself convinced and more loyal than ever. The second visitor was a lady who had come to attend church. She is the senior wife of a chief named Thekho, a son of Moshesh. She impressed us as a person of great force of character and great conversational gifts, was dressed in a fashionable hat and an enormous black velvet mantle, and plied us with numerous questions regarding the Queen, her family, and her government. She lives on the hill among her dependents, exerts great influence, 
and has done good service in resisting the reactionary tendencies of her brother-in-law Masupha, a dogged and turbulent old pagan.

The mission station lies at the foot of the hill of Thaba Bosiyo, in a singular region where crags of white or grey sandstone, detached from the main mass of the tabular hills, stand up in solitary shafts and pinnacles, and give a weird, uncanny look to the landscape. The soil is fertile and well cultivated, but being alluvial, it is intersected in all directions by the channels of streams, which have dug so deep into it that much good land is every year lost by the mischief the streams work when in flood. The sides of these channels are usually vertical, and often eight, ten, or even twelve feet high, so that they offer a serious obstacle to travellers either by waggon or on horseback. The hill itself is so peculiar in structure, and has played such a part in history, as to deserve some words of description. It is nearly two miles long and less than a mile across, elliptical in form, rising about five hundred feet above its base, and breaking down on every side in a line of cliffs, which, on the northwest and north side (toward the mission station), are from twenty to forty feet high. On the other side, which I could not so carefully examine, they are apparently higher. These cliffs are so continuous all round as to leave-so one is told-only three spots in the circumference where they can be climbed; and although I noticed one or two other places where a nimble cragsman might make his 
way up, it is at those three points only that an attack by a number of men could possibly be made. The easiest point is where a dyke of igneous rock, thirty feet wide, strikes up the face of the hill from the north-north-west, cutting through the sandstone precipice. The decomposition of this dyke has opened a practicable path, from fifteen to twentyfive feet in width, to the top. The top is a large grassy flat, with springs of water and plenty of good pasture.

It was this natural fortress that the Basuto chief Mosheshwe, or, as he is usually called, Moshesh, chose for his dwelling and the stronghold of his tribe, in A.D. I824. The conquests of the ferocious Tshaka had driven thousands of Kafirs from their homes in Natal and on both sides of the Vaal River. Clans had been scattered, and the old dynasties rooted out or bereft of their influence and power. In the midst of this confusion, a young man, the younger son of a chief of no high lineage, and belonging to a small tribe, gathered round him a number of minor clans and fugitives from various quarters, and by his policy-astute, firm, and tenacious-built them up into what soon became a powerful nation. Moving hither and thither along the foot of the great Maluti range, his skilful eye fixed on Thaba Bosiyo as a place fit to be the headquarters of the nation. There was good land all around, the approaches could be easily watched, and the hill itself, made almost impregnable by nature, supplied pasture for the cattle as well as perennial water. 
By tactfully conciliating the formidable tribes and boldly raiding the weaker ones, Moshesh rapidly acquired wealth (that is to say, cattle), strength, and reputation, so that in 1836 , when the emigrant Boers moved up into what is now the Free State, he was already the second power north of the mountains, inferior only to the terrible Mosilikatze. The latter on one occasion (in $183_{1}$ ) had sent a strong force of Matabili against him. Moshesh retired into his hill, which he defended by rolling down stones on the assailants; and when the invaders were presently obliged to retreat for want of food, he sent supplies to them on their way back, declaring his desire to be at peace with all men. The Matabili never attacked him again. In 1833 he intimated to the missionaries of the Paris Evangelical Society his willingness to receive them, planted them at Morija, and gave them afterward their present station at the foot of Thaba Bosiyo, his own village being, of course, on the top. Their counsels were of infinite value to him in the troublous times that followed, and he repaid them by constant protection and encouragement. But though he listened, like so many Kafir chiefs, to sermons, enjoyed the society of his French friends, and was himself fond of quoting Scripture, he never became a Christian and was even thought to have, like Solomon, fallen in his old age somewhat more under heathen influences. Many were the wars he had to sustain with the native tribes who lived round him, as well as with the white settlers in the Orange River territory to the north, and many 
the escapes from danger which his crafty and versatile policy secured. Two of these wars deserve special mention, for both are connected with the place I am describing. In December, I852, Sir George Cathcart, then Governor of Cape Colony, crossed the Caledon River a little above Maseru and led a force of two thousand British infantry and five hundred cavalry, besides artillery, against the Basutos. One of the three divisions in which the army moved was led into an ambush, severely handled by the nimble Basuto horsemen, and obliged to retreat. The division which Sir George himself led found itself confronted, when it reached the foot of Thaba Bosiyo, by a body of Basutos so numerous and active that it had great difficulty in holding its ground, and might have been destroyed but for the timely arrival of the third division just before sunset. The British general intrenched himself for the night in a strong position ; and next morning, realizing at length the difficulties of his enterprise, set out to retire to the Caledon River. Before he reached it, however, a message from Moshesh overtook him. That wary chief, who knew the real strength of the British better than did his people, had been driven into the war by their over-confidence and their reluctance to pay the cattle fine which the Governor had demanded. Now that there was a chance of getting out of it he resolved to seize that chance, and after consultation with one of the French missionaries, begged Sir George Cathcart for peace, acknowledging himself to be the 
weaker party, and declaring that he would do his best to keep his tribesmen in order. The Governor, glad to be thus relieved of what might have proved a long and troublesome war, accepted these overtures. The British army was marched back to Cape Colony, and Moshesh thereafter enjoyed the fame of being the only native potentate who had come out of a struggle with Great Britian virtually if not formally the victor.

But a still severer ordeal was in store for the virgin fortress and its lord. After much indecisive strife, the whites and the Basutos were, in I865, again engaged in a serious war. The people of what had then become (see Chapter XI) the Orange Free State had found the Basutos troublesome neighbours, and a dispute had arisen regarding the frontier line. The Free State militia, well practised in native warfare, invaded Basutoland, reduced many of the native strongholds, and besieged Thaba Bosiyo. A storming party advanced to carry the hill by assault, mounting the steep open acclivity to the passage which is opened (as already mentioned) by the greenstone dyke as it cuts its way through the line of sandstone cliff. They had driven the Basutos before them, and had reached a point where the path leads up a narrow cleft formed by the decomposition of the dyke, between walls of rock some twenty feet high. Thirty yards more would have brought them to the open top of the hill, and Moshesh would have been at their mercy. But at this moment a bullet from one of 
the few muskets which the defenders possessed, fired by a good marksman from the rock above the cleft, pierced Wepener, the leader of the assailants. The storming party halted, hesitated, fell back to the bottom of the hill, and the place was once more saved. Not long after, Moshesh, finding himself likely to be overmastered, besought the Imperial Government, which had always regarded him with favour since the conclusion of Sir George Cathcart's war, to receive him and his people, "and let them live under the large folds of the flag of England." The High Commissioner intervened, declaring the Basutos to be thenceforward British subjects, and in I 869 a peace was concluded with the Free State, by which the latter obtained a fertile strip of territory along the north-west branch of the Caledon, which had previously been held by Moshesh, while the Basutos came (in I87 I) under the administrative control of Cape Colony. Moshesh died soon afterward, full of years and honour, and leaving a name which has become famous in South Africa. He was one of the remarkable instances, like Toussaint l'Ouverture and the Hawaiian king Kamehameha the First, of a man, sprung from a savage race, who effected great things by a display of wholly exceptional gifts. His sayings have become proverbs in native mouths. One of them is worth noting, as a piece of grim humour, a quality rare among the Kafirs. Some of his chief men had been urging him, after he had become powerful, to take vengeance upon certain cannibals who were believed to 
have killed and eaten his grandparents. Moshesh replied : "I must consider well before I disturb the sepulchres of my ancestors."

Basutoland remained quiet till I879, when the Cape Government, urged, it would appear, by the restless spirit of Sir Bartle Frere (then Governor), conceived the unhappy project of disarming the Basutos. It was no doubt a pity that so many of them possessed firearms; but it would have been better to let them keep their weapons than to provoke a war; and the Cape Prime Minister, who met the nation in its great popular assembly, the Pitso, had ample notice through the speeches delivered there by important chiefs of the resistance with which any attempt to enforce disarmament would be met. However, rash counsels prevailed. The attempt was made in I880; war followed, and the Basutos gave the colonial troops so much trouble that in I 883 the Colony proposed to abandon the territory altogether. Ultimately, in $\mathrm{I} 884$, the Imperial Government took it over, and has ever since administered it by a Resident Commissioner.

The Basuto nation, which had been brought very low at the time when Moshesh threw himself upon the British Government for protection, has latterly grown rapidly, and now numbers over 220,000 souls. This increase is partly due to an influx of Kafirs from other tribes, each chief encouraging the influx, since the new retainers who surround him increase his importance. But it has now reached a point when it ought to be stopped, because all the 
agricultural land is taken up for tillage, and the pastures begin scarcely to suffice for the cattle. The area is 10,263 square miles, about two-thirds that of Switzerland, but by far the larger part of it is wild mountain. No Europeans are allowed to hold land, and a license is needed even for the keeping of a store. Neither are any mines worked. European prospectors are not permitted to come in and search for minerals, for the policy of the authorities has been to keep the country for the natives; and nothing alarms the chiefs so much as the occasional appearance of these speculative gentry, who, if allowed a foothold, would soon dispossess them. Thus it remains doubtful whether either gold or silver or diamonds exist in "payable" quantities.

The natives, however, go in large numbers - in I $895^{-6}$ as many as 28 , 000 went out-to work in the mines at Kimberley and on the Witwatersrand, and bring back savings, which have done much to increase the prosperity of the tribe. At present they seem fairly contented and peaceable. The land belongs to the nation, and all may freely turn their cattle on the untilled parts. Fields, however, are allotted to each householder by the chief, to be tilled, and the tenant, protected by public opinion, retains them so long as he tills them. He cannot sell them, but they will pass to his children. Ordinary administration, which consists mainly in the allotment and management of land, is left to the chief; as also ordinary jurisdiction, both civil and 
criminal. The present tendency is for the disposing power of the chief over the land to increase ; and it is possible that British law may ultimately turn him, as it turned the head of an Irish sept, into an owner. The chief holds his court at his kraal, in the open air, settles disputes and awards punishments. There are several British magistrates to deal with grave offences, and a force of 220 native police, under British officers. Lerothodi, as the successor of Moshesh, is Paramount Chief of the nation; and all the greater chieftainships under him are held by his uncles and cousins, - sons and grandsons of the founder of the dynasty,-while there are also a few chiefs of the second rank belonging to other families. Some of the uncles, especially Masupha, who lives at the foot of Thaba Bosiyo, and is an obstinately conservative heathen, give trouble both to Lerothodi and to the British Commissioner, their quarrels turning mainly on questions of land and frontier. But on the whole, things go on as well as can be expected in such a world as the present; disturbances tend to diminish; and the horses or cattle that are occasionally stolen from the Free State farmers are always recovered for their owners, unless they have been got away out of Basutoland into the colonial territories to the south and west. As far back as 1855, Moshesh forbade the "smelling out" of witches, and now the British authorities have suppressed the more noxious or offensive kinds of ceremonies practised by the Kafirs. Otherwise they interfere as little as may be with native ways, 
CHAP.

trusting to time, peace, and the missionaries to secure the gradual civilisation of the people. Once a year the Commissioner meets the whole people, in their national assembly called the Pitso, - the name is derived from their verb "to call,"-which in several points recalls the agora, or assembly of freemen described in the Homeric poems. The Paramount Chief presides, and debate is mainly conducted by the chiefs; but all freemen, gentle and simple, have a right to speak in it. There is no voting, only a declaration, by shouts, of the general feeling. Though the Paramount Chief has been usually the person who convokes it, a magnate lower in rank might always, like Achilles in the Iliad, have it summoned when a fitting occasion arose. And it was generally preceded by a consultation among the leading men, though I could not discover that there was any regular council of chiefs. ${ }^{1}$ In all these points the resemblance to the primary assemblies of the early peoples of Europe is close enough to add another to the arguments, already strong, which discredit the theory that there is any such thing as an "Aryan type" of institutions, and which suggest the view that in studying the polities of primitive nations we must not take affinities of language as the basis of a classification.

To-day the Pitso has lost much of its old import-

1 Gungunhana however had a sort of council of chiefs and confidential advisers which he called together at intervals, and which bore some resemblance to the Homeric Boule and to the earliest form of our own Curia Regis. 
ance, and tends to become a formal meeting, in which the British Commissioner causes new regulations to be read aloud, inviting discussion on points which any one present may desire to raise, and addresses the people, awarding praise or blame, and adding such exhortations as he thinks seasonable. The missionaries and the chief British officials are usually present. In perusing the shorthand report of the great Pitso held in 1879 , at which the question of disarmament was brought forward by the Cape Prime Minister, I was struck by the freedom and intelligence with which the speakers delivered their views. One observed: "This is our parliament, though it is a very disorderly parliament, because we are all mixed up, young and old; and we cannot accept any measure without discussion." Another commented severely upon an unhappy phrase that had been used at Cape Town by a member of the Cape Government: "Mr. $\mathrm{U}$. said the Basutos were the natural enemies of the white man, because we were black. Is that language which should be used by a high officer of the Government? Let sentiments like these pass away-we are being educated to believe that all people are equal, and feel that sentiments like these are utterly wrong." A third claimed that the people must keep their guns, because "at our circumcision we were given a shield and an assagai, and told never to part with them; and that if ever we came back from an expedition and our shield and assagai were not found before our house, we 
should die the death." And a fourth, wishing to excuse any vehement expression he might use, observed: "We have a proverb which says that a man who makes a mistake in a public assembly cannot be killed." In this proverb there is the germ of the English "privilege of Parliament." It is easy to gather from the whole proceedings of these Pitsos how much more popular government has been among the Basutos than it was among the Zulus or Matabili. Tshaka or Lo Bengula would in a moment have had the neck twisted of any one who ventured to differ publicly from his opinion. In this respect the Basutos resemble their kinsfolk the Bamangwato, among whom Khama rules as a chief amenable to public opinion, which, in that instance, is unfortunately far behind the enlightened purposes of the sovereign.

Nowhere has the gospel made such progress among the Kafirs as in Basutoland. The missionaries,-French, Protestant, Roman Catholic, and English Episcopalian,-working not only independently but on very different lines, have brought nearly fifty thousand natives under Christian influences, as members or adherents. Not all of these are baptized converts-the Franco-Swiss missionaries, by whom far the largest part of the work has been done, tell me that baptisms do not increase fast; and they are wise in not measuring the worth of their work by the number of baptisms. Education is spreading. At the last public examinations at the Cape, the French Protestant mission- 
aries sent up twenty Basuto boys, of whom ten passed in honours, and ten in high classes, the standard being the same for whites and blacks. There are now one hundred and fifty schools in the country, all but two of which are conducted by the missionaries.

Strange waves of sentiment pass over the people, at one time carrying them back to paganism, at another inclining them to Christianity-the first sign of the latter tendency being discernible in an increase of attendance at the mission schools. The women are more backward than the men, because they have been kept in subjection, and their intelligence has remained only half developed. But their condition is improving; men now work with them in the fields, and they demand clothes instead of so much oil, wherewith to smear their bodies. As education becomes more diffused, old heathen customs lose their hold, and will probably in thirty years have disappeared. The belief in ghosts and magic is, of course, still strong. On the top of Thaba Bosiyo we were shown the graves of Moshesh and several of his brothers and sons, marked by rude stones, with the name of each chief on his stone. But we were told that in reality the bodies of Moshesh and of several of the others are not here at all, having been dug up and reinterred more than a mile away near the foot of the hill. Were the body under the stone, the ghost, which usually dwells near the body, would be liable to be called up by necromancers, and might be compelled. 
to work mischief to the tribe-mischief which would be serious in proportion to the power the spirit possessed while alive. Considering, however, that nearly all the ancient world held similar beliefs, and that a large part of the modern world, even in Europe, still clings to them, the persistence of these interesting superstitions need excite no surprise, nor are they productive of much practical ill, now that the witch-doctor is no longer permitted to denounce men to death.

The material progress of the people has been aided by the enactment of stringent laws against the sale of white men's intoxicating liquors, though some of the chiefs show but a poor example of obedience to these laws, the enforcement of which is rendered difficult by the illicit sale which goes on along the frontiers where Basutoland touches the Free State and the eastern part of Cape Colony. The old native arts and industries decline as European goods become cheaper, and industrial training has now become one of the needs of the people. It is an encouraging sign that, under the auspices of Lerothodi, a sum of $£ 3,184$ sterling was collected from the tribe in $1895^{-96}$, for the foundation of an institution to give such training. The receipts from import duties have so much increased that the contribution of $£^{\mathrm{I} 8}$, 000 paid by Cape Colony is now annually reduced by nearly $£^{1} 2,000$, and the hut tax, of ten shillings per hut, now easily and promptly collected, amounts to $£^{23,000}$ a year, leaving a surplus, out of which 
$£ \mathrm{r}, 300$ is paid to the Cape. Basutoland is within the South African Customs Union.

These facts are encouraging. They show that, so far, the experiment of leaving a native race to advance in their own way, under their own chiefs, but carefully supervised by imperial officers, has proved successful. A warlike, unstable, and turbulent, although intelligent people, while increasing fast in wealth and material comfort, has also become more peaceful and orderly, and by the abandonment of its more repulsive customs is passing from savagery to a state of semi-civilisation. Still the situation has its anxieties. The very prosperity of the country has drawn into it a larger population than the arable and pastoral land may prove able to support. The Free State people are not friendly to it, and many politicians in Cape Colony would like to recover it for the Colony, while many white adventurers would like to prospect for mines, or to oust the natives from the best lands. The natives themselves are armed, and being liable, like all natives, to sudden fits of unreason, may conceivably be led into disorders which would involve a war and the regular conquest of the country. The firmness as well as the conciliatory tactfulness which the first Commissioner, Sir Marshal Clarke, and his successor, the present Acting Commissioner, have shown, has hitherto averted these dangers, and has inspired the people with a belief in the good will of the Government. 
If the progress of recent years can be maintained for thirty years more, the risk of trouble will have almost disappeared, for by that time a new generation, unused to war, will have grown up. Whoever feels for the native and cares for his future must wish a fair chance for the experiment that is now being tried in Basutoland, of letting him develop in his own way, shielded from the rude pressure of the whites. 
PART IV

SOME SOUTH AFRICAN QUESTIONS 



\section{CHAPTER XXI}

BLACKS AND WHITES

Everywhere in South Africa, except in the Witwatersrand and Cape Town, the black people greatly outnumber the whites. In the Orange Free State they are nearly twice as numerous, in Cape Colony and the Transvaal more than thrice as numerous, in Natal ten times as numerous, while in the other territories, British, German, and Portuguese, the disproportion is very much greater, possibly some four or five millions of natives against nine or ten thousand Europeans. The total number of whites south of the Zambesi hardly reaches 750,000 , while that of the blacks is roughly computed at from six to eight millions. At present, therefore, so far as numbers go, the country is a black man's country.

It may be thought that this preponderance of the natives is only natural in a region by far the larger part of which has been very recently occupied by Europeans, and that in time immigration and the natural growth of the white element will reduce the disproportion. This explanation, however, does not 
meet the facts. The black race is at present increasing at least as rapidly as the white. Unlike those true aborigines of the country, the Hottentots and Bushmen, who withered up and vanished away before the whites, the Kafirs, themselves apparently intruders from the North, have held their ground, not only in the wilder country where they have been unaffected by the European, but in the regions where he has conquered and ruled over them. They are more prolific than the whites, and their increase is not restrained by those prudential checks which tell upon civilised man, because, wants being few, subsistence in a warm climate with abundance of land is easy. Formerly two powerful forces kept down population:-war, in which no quarter was given and all the property of the vanquished was captured or destroyed, and the murders that went on at the pleasure of the chief, and usually through the agency of the witch-doctor. Now both these forces have been removed by the action of European government, which has stopped war and restrains the caprice of the chiefs. Relieved from these checks, the Kafirs of the south coast and of Basutoland, the regions in which observation has been easiest, are multiplying faster than the whites, and there is no reason why the same thing should not happen in other parts of the country. The number of the Fingoes, for instance (though they are no doubt an exceptionally thrifty and thriving tribe), is to-day ten times as great as it was fifty or sixty years ago. Here is a fact of serious import for the future. 
Two races, far removed from one another in civilisation and mental condition, dwell side by side. Neither race is likely to extrude or absorb the other. What then will be their relations, and how will the difficulties be met to which their juxtaposition must give rise?

The colonies of Britain over the world fall into two groups: those which have received the gift of self-government, and those which are governed from home through executive officials placed over each of them. Those of the latter class, called Crown Colonies, are all (with the insignificant exceptions of the Falkland Islands and Malta) within the tropics, and are all peopled chiefly by coloured races,negroes, Indians, Malays, Polynesians, or Chinese, - with a small minority of whites. The selfgoverning colonies, on the other hand, are all situated in the temperate zone, and are all, with one exception, peopled chiefly by Europeans. It is because they have a European population that they have been deemed fit to govern themselves, just as it is because the tropical colonies have a predominantly coloured population that the supremacy of the Colonial Office and its local representatives is acquiesced in as fit and proper. Every one perceives that representative assemblies based on a democratic franchise, which are capable of governing Canada or Australia, would not succeed in the West Indies or Ceylon or Fiji.

The one exception to this broad division, the one case of self-governing communities in which the 
majority of the inhabitants are not of European stock, is to be found in South Africa. The general difficulty of adjusting the relations of a higher and a lower race, serious under every kind of government, here presents itself in the special form of the construction of a political system which, while democratic as regards one of the races, cannot safely be made democratic as regards the other. This difficulty, though new in the British empire, is not new in the Southern States of America, which have been struggling with it for years ; and it is instructive to compare the experience of South Africa with that through which the Southern States have passed since the War of Secession.

Throughout South Africa-and for this purpose no distinction need be drawn between the two British colonies and the two Boer republics-the people of colour may be divided into two classes: the wild or tribal natives, who are, of course, by far the more numerous, and the tame or domesticated natives, among whom one may include, though they are not aborigines, but recent incomers, the Indians of Natal and the Transvaal, as well as the comparatively few Malays of the Cape.

It will be convenient to deal with the two classes separately, and to begin with the semi-civilised or non-tribal natives, who have been for the longest period under white influences, and whose present relations with the whites indicate what the relations of the races are likely to be, for some time to come, in all parts of the country. 
The non-tribal people of colour live in the Cape Colony, except the south-eastern parts (called Pondoland and Tembuland), in Natal, in the Orange Free State, and in the southern parts of the Transvaal. They consist of three stocks : (I) the so-called Cape boys, a mixed race formed by the intermarriage of Hottentots and Malays with the negro slaves brought in early days from the west coast, plus some small infusion of Dutch blood; (2) the Kafirs no longer living in native communities under their chiefs; and (3) the Indian immigrants who (together with a few Chinese) have recently come into Natal and the Transvaal, and number about 60,000 , not counting in the indentured coolies who are to be sent back to India. There are no data for conjecturing the number of Cape boys and domesticated Kafirs, but it can hardly exceed 400,000.

These coloured people form the substratum of society in all the four States above mentioned. Some till the land for themselves, while others act as herdsmen or labourers for white farmers, or work at trades for white employers. They do the harder and rougher kinds of labour, especially of outdoor labour. Let me remind the reader of what has been incidentally observed before, and must now be insisted on as being the capital feature of South African life-the fact that all unskilled work is done by black people. In many parts of the country the climate is not too hot for men belonging to the north European races to work in the fields, for the sun's rays are generally tempered by a breeze, the nights 
are cool, and the dry air is invigorating. Had South Africa, like California or New South Wales, been colonised solely by white men, it would probably, like those countries, have to-day a white labouring population. But, unluckily, South Africa was colonised in the seventeenth century, when the importation of negro slaves was deemed the easiest means of securing cheap and abundant labour. From ${ }_{1} 65^{8}$ onward till, in 1834 , slavery was abolished by the British Parliament, it was to slaves that the hardest and humblest kinds of work were allotted. The white people lost the habit of performing manual toil, and acquired the habit of despising it. No one would do for himself what he could get a black man to do for him. New settlers from Europe fell into the ways of the country, which suited their disinclination for physical exertion under a sun hotter than their own. Thus, when at last slavery was abolished, the custom of leaving menial or toilsome work to people of colour continued as strong as ever. It is as strong as ever to-day. The only considerable exception, that which was furnished by the German colonists who were planted in the eastern province after the Crimean War of 1854 , has ceased to be an exception ; for the children of those colonists have now, for the most part, sold or leased their allotments to Kafirs, who till the soil less efficiently than the sturdy old Germans did. The artisans who to-day come from Europe adopt the habits of the country in a few weeks or months. The English carpenter hires a native "boy" to 
carry his bag of tools for him; the English bricklayer has a native hodman to hand the bricks to him, which he proceeds to set ; the Cornish or Australian miner directs the excavation of the seam and fixes the fuse which explodes the dynamite, but the work with the pickaxe is done by the Kafir. The herdsmen who drive the cattle or tend the sheep are Kafirs, acting under the orders of a white. Thus the coloured man is indispensable to the white man, and is brought into constant relations with him. $\mathrm{He}$ is a necessary part of the economic machinery of the country, whether for mining or for manufacture, for tillage or for ranching.

But though the black people form the lowest stratum of society, they are not all in a position of personal dependence. A good many Kafirs, especially in the eastern province, own the small farms which they till, and many others are tenants, rendering to their landlord, like the métayers of France, a half of the produce by way of rent. Some few natives, especially near Cape Town, are even rich, and among the Indians of Natal a good many have thriven as shopkeepers. There is no reason to think that their present exclusion from trades requiring skill will continue. In I894 there were Kafirs earning from five shillings to seven ishillings and sixpence a day as riveters on an iron bridge then in course of construction. I was informed by a high railway official that many of them were quite fit to be drivers or stokers of locomotives, though white sentiment (which tolerates them as navvies or 
platelayers) made it inexpedient to place them in such positions. Many work as servants in stores, and are little more prone to petty thefts than are Europeans. They have dropped their old usages and adopted European habits, have substituted European clothes for the kaross of the wild or "red" Kafir, have lost their tribal attachments, usually speak Dutch, or even perhaps English, and to a considerable extent, especially in the western province and in the towns, have become Christians. The Indians are, of course, Mohammedans or heathens, the Malays (of whom there are only about I 3,000), Mohammedans. They travel a good deal by rail, and are, especially the Kafirs, eager for instruction, which is provided for them only in the mission schools. Some will come from great distances to get taught, and those who can write are very fond of corresponding with one another. Taken as a whole, they are a quiet and orderly people, not given to crimes of violence, and less given (so far as I could gather) to pilfering than are the negroes of the Southern States of America. The stealing of stock from farms has greatly diminished. Assaults upon women, such as are frequent in those States, and have recently caused a hideous epidemic of lynching, are extremely rare ; indeed, I heard of none, save one or two in Natal, where the natives are comparatively wild and the whites scattered thinly among them. So few Kafirs have yet received a good education, or tried to enter occupations requiring superior intelligence, that it is hardly 
possible to speak confidently of their capacity for the professions or the higher kinds of commerce; but judicious observers think they will in time show capacity, and tell you that their inferiority to white men lies less in mere intellectual ability than in power of will and steadiness of purpose. They are unstable, improvident, easily discouraged, easily led astray. When the morality of their old life, in which they were ruled by the will of their chief, the opinion of their fellows, and the traditional customs of the tribe, has been withdrawn from them, it may be long before any new set of principles can gain a like hold upon them.

That there should be little community of ideas, and by consequence little sympathy, between such a race and the whites is no more than any one would expect who elsewhere in the world has studied the phenomena which mark the contact of dissimilar peoples. But the traveller in South Africa is astonished at the strong feeling of dislike and contempt-one might almost say of hostility-which the bulk of the whites show to their black neighbours. He asks what can be the cause of it. It is not due, as in the Southern States of America, to political resentment, for there has been no sudden gift to former slaves of power over former masters. Neither is it sufficiently explained by the long conflicts with the south-coast Kafirs; for the respect felt for their bravery has tended to efface the recollection of their cruelties. Neither is it caused (except as respects the petty Indian traders) by the 
CHAP.

dislike of the poorer whites to the competition with them in industry of a class living in a much ruder way and willing to accept much lower wages. It seems to spring partly from the old feeling of contempt for the slaves, a feeling which has descended to a generation that has never seen slavery as an actual system ; partly from physical aversion ; partly from an incompatibility of character and temper, which makes the faults of the coloured man more offensive to the white than the (perhaps morally as grave) faults of members of his own white stock. Even between civilised peoples, such as Germans and Russians, or Spaniards and Frenchmen, there is a disposition to be unduly annoyed by traits and habits which are not so much culpable in themselves as distasteful to men constructed on different lines. This sense of annoyance is naturally more intense toward a race so widely removed from the modern European as the Kafirs are. Whoever has travelled among people of a race greatly weaker than his own must have sometimes been conscious of an impatience or irritation which arises when the native either fails to understand or neglects to obey the command given. The sense of his superior intelligence and energy of will produces in the European a sort of tyrannous spirit, which will not condescend to argue with the native, but overbears him by sheer force, and is prone to resort to physical coercion. Even just men, who have the deepest theoretical respect for human rights, are apt to be carried away by the consciousness of superior strength, and to become 
despotic, if not harsh. To escape this fault, a man must be either a saint or a sluggard. And the tendency to race enmity lies very deep in human nature. Perhaps it is a survival from the times when each race could maintain itself only by slaughtering its rivals.

The attitude of contempt I have mentioned may be noted in all classes, though it is strongest in those rough and thoughtless whites who plume themselves all the more upon their colour because they have little else to plume themselves upon, while among the more refined it is restrained by self-respect and by the sense that allowances must be made for a backward race. It is stronger among the Dutch than among the English, partly, perhaps, because the English wish to be unlike the Dutch in this as in many other respects. Yet one often hears that the Dutch get on better with their black servants than the English do, because they understand native character better, and are more familiar in their manners, the Englishman retaining his national stiffness. The laws of the Boer republics are far more harsh than those of the English colonies, and the Transvaal Boers have been always severe and cruel in their dealings with the natives. But the English also have done so many things to regret that it does not lie with them to cast stones at the Boers, and the mildness of colonial law is largely due to the influence of the home government, and to that recognition of the equal civil rights of all subjects which has long pervaded the 
CHAP.

common law of England. Only two sets of Europeans are free from reproach : the imperial officials, who have almost always sought to protect the natives, and the clergy, both Protestant and Roman Catholic, who have been the truest and most constant friends to the Hottentot and the Kafir, sometimes even carrying their zeal beyond what discretion could approve.

Deep and wide-spread as is the sentiment of aversion to the coloured people which I am describing, it must not be supposed that the latter are generally ill-treated. There is indeed a complete social separation. Intermarriage, though permitted by law in the British colonies, is extremely rare, and illicit unions are uncommon. Sometimes the usual relations of employer and employed are reversed, and a white man enters the service of a prosperous Kafir. This makes no difference as respects their social intercourse, and I remember to have heard of a case in which the white workman stipulated that his employer should address him as "boss." Black children are very seldom admitted to schools used by white children ; indeed, I doubt if the two colours are ever to be seen on the same benches, except at Lovedale and in one or two of the mission schools in Cape Town, to which, as charging very low fees, some of the poorest whites send their children. I heard of a wealthy coloured man at the Paarl, a Dutch town north of Cape Town, who complained that, though he paid a considerable sum in taxes, he was not permitted to send his daughter to any of the 
schools in the place. In the Protestant Episcopal, Presbyterian, Congregationalist, and Methodist churches, and of course among the Roman Catholics, blacks are admitted along with whites to the sacrament of the Lord's Supper; but this (so I was told) is not the case in the Dutch Reformed Church. An eminent and thoughtful ecclesiastic in Natal deplored to me the complete want of sympathy on the part of the white congregations with the black ones worshipping near them. It rarely, if ever, happens that a native, whatever his standing among his own people,-for to the white there is practically no difference between one black and another,-is received within a white man's house on any social occasion; indeed, he would seldom be permitted, save as a servant, to enter a private house, but would be received on the stoep (veranda). When Khama, the most important chief now left south of the Zambesi, a Christian and a man of high personal character, was in England in 1895, and was entertained at lunch by the Duke of Westminster and other persons of social eminence, the news of the reception given him excited annoyance and disgust among the whites in South Africa. I was told that at a gardenparty given a few years ago by the wife of a white bishop, the appearance of a native clergyman caused many of the white guests to withdraw in dudgeon. Once when myself a guest at a mission station in Basutoland I was asked by my host whether I had any objection to his inviting to the family meal a 
CHAP.

native pastor who had been preaching to the native congregation. When I expressed surprise at the question, my host explained that race feeling was so strong among the colonists that it would be deemed improper, and indeed insulting, to make a black man sit down at the same table with a white guest, unless the express permission of the latter had first been obtained. But apart from this social disparagement, the native does not suffer much actual wrong. Now and then, on a remote farm, the employer will chastise his servant with a harshness he would not venture to apply to a white boy. A shocking case of the kind occurred a few years ago in the eastern province. A white farmer-an Englishman, not a Boer-flogged his Kafir servant so severely that the latter died; and when the culprit was put on his trial, and acquitted by a white jury, his white neighbours escorted him home with a band of music. More frequently, unscrupulous employers, especially on the frontiers of civilisation, will try to defraud their native workmen, or will provoke them by ill-usage to run away before the day of payment arrives. But there are no lynchings, as in America, and the white judges and magistrates, if not always the juries, administer the law with perfect impartiality.

As regards the provisions of the law, one must distinguish between the British colonies and the Dutch republics. In the former the ordinary civil rights of whites and blacks are precisely the same, though there exist certain police provisions which 
are applicable only to the latter. Cape Colony has a so-called "curfew law," requiring natives who are out of doors after dark to be provided with a pass -a law which is found oppressive by the best class of natives, educated and respectable men, though defended as necessary for public order, having regard to the large black population of the lower class, and their propensity to drink and petty offences. There are also certain "labour laws," applying to natives only, and particularly to those on agricultural locations, which are intended to check the disposition of Kafirs living on native reserves to become idle or to take to vagrancy. There is no doubt a danger that people who have never acquired habits of steady industry-for the tribal Kafir leaves to his wives the cultivation of his plot of maize or sorghum-may relapse into a laziness hurtful to their own progress, seeing that a few weeks' labour is sufficient to provide all the food needed for a whole year. In the transition from one state of society to another exceptional legislation is needed, and a prima facie case for the so-called "Glen Grey Act" and similar laws may, therefore, be made out.

The friends of the natives whom I consulted on the subject, and one or two of the most educated and representative Kafirs themselves, did not seem to object to this Act in principle, though they criticised its methods and many of its details. But as all such laws are prompted not only by regard for the welfare of the Kafir, but also by the desire of the 
white colonist to get plenty of labour and to get it cheap, they are obviously open to abuse and require great care in their administration. The whole subject of native labour and native land tenure is an intricate and difficult one, which I have not space to discuss here, though I obtained a good deal of information regarding it. It is also an urgent one, for the population which occupies the native reserves is in some districts growing so fast that the agricultural land will soon cease to feed them, while the pasture is suffering from being overstocked. Most of my informants agreed in thinking that the control of the British magistrate over the management of lands in reservations was better than that of the native headman, and ought to be extended, and that the tenure of farms by individual natives outside the reservations ought to be actively encouraged. They deemed this a step forward in civilisation ; and they also held that it is necessary to prevent native allotments, even when held by individuals, from being sold to white men, conceiving that without such a prohibition the whites will in course of time oust the natives from the ownership of all the best land.

One law specially applicable to natives has been found most valuable in Natal, as well as in the territories of the Chartered Company, and ought to be enacted in Cape Colony also, viz., an absolute prohibition of the sale to them of intoxicating spirits. The spirits made for their consumption are rough and fiery, much more deleterious than European whisky or brandy or hollands. Unfortunately, the 
interests of the wine-growers and distillers in the Colony have hitherto proved strong enough to defeat the bills introduced for this purpose by the friends of the natives. Though some people maintain that the Dutch and anti-native party resist this much-needed measure because they desire through strong drink to weaken and keep down the natives, I do not believe in the existence of any such diabolical motive. Commercial self-interest, or rather a foolish and short-sighted view of self-interest,--for in the long run the welfare of the natives is also the welfare of the whites,-sufficiently accounts for their conduct; but it is a slur on the generally judicious policy of the Colonial Legislature.

In the two Dutch republics the English principle of equal civil rights for white and black finds no place. One of the motives which induced the Boers of 1836 to trek out of the Colony was their disgust at the establishment of such equality by the British Government. The Grondwet (fundamental law) of the Transvaal Republic declared, in 1858 , and declares to-day, that "the people will suffer no equality of whites and blacks, either in state or in church." 1 Democratic republics are not necessarily respectful of what used to be called human rights, and neither the "principles of 1789" nor those of the American Declaration of Independence find recognition among

1 The Boers are a genuinely religious people, but they have for gotten I Cor. xii. I3, Gal. iii. 28, and Col. iii. I I. Many nations have been inspired by the Old Testament, but few indeed are the instances in which any has paid regard to the New. 
CHAP.

the Boers. Both in the Transvaal and in the Orange Free State a native is forbidden to hold land, and is not permitted to travel anywhere without a pass, in default of which he may be detained. (In the Free State, however, the sale of intoxicants to him is forbidden, and a somewhat similar law, long demanded by the mine-owners, has very recently been enacted in the Transvaal.) Nor can a native serve on a jury, whereas in Cape Colony he is legally qualified, and sometimes is empanelled. The whites may object to his presence, but a large-minded and strong-minded judge can manage to overcome their reluctance. For a good while after they settled in the Transvaal the Boers had a system of apprenticing Kafir children which was with difficulty distinguishable from predial serfdom; and though they have constantly denied that they sanctioned either the kidnapping of children or the treatment of the apprentices as slaves, there is reason to think that in some parts of the country these abuses did exist. It seems clear, however, that no such practices are now legal.

Political rights, have, of course, never been held by persons of colour in either of the Dutch republics, nor has it ever been proposed to grant them. Boer public opinion would scout such an idea, for it reproaches the people of Cape Colony now with being "governed by black men," because the electoral franchise is there enjoyed by a few persons of colour. In the two colonies the history of the matter is as follows. When representative government was established, and the electoral franchise conferred 
upon the colonists in 1853 , no colour-line was drawn; and from that time onward black people have voted, though of course not very many were qualified under the law to vote. Some years ago, however, the whites, and the Dutch party in particular, became uneasy at the strength of the coloured element, though it did not vote solid, had no coloured leaders, and was important only in a very few constituencies. Accordingly, an Act was passed in 1892, establishing a combined educational and property qualificationthat is to say, the ownership of a house or other building of the value of $£ 75$ or upwards, or the being in receipt of a salary of $£ 50$ per annum, with the ability to sign one's name and write one's address and occupation. This Act, which did not apply to those already registered in any particular district and claiming to be re-registered therein, is expected to keep down the number of coloured voters; and as it applies to whites also, there is no inequality of treatment. Tribal Kafirs have, of course, never had the franchise at all. Neither the natives-the most substantial and best educated among whom possess the qualifications required-nor their friends complain of this law, which may be defended on the ground that, while admitting those people of colour whose intelligence fits them for the exercise of political power, it excludes a large mass whose ignorance and indifference to public questions would make them the victims of rich and unscrupulous candidates. It is, perhaps, less open to objection than some of the attempts recently made in the 
Southern States of America to evade the provisions of the amendments to the federal Constitution under which negroes obtained the suffrage. In Natal nearly all the Kafirs live under native law, and have thus been outside the representative system; but the Governor has power to admit a Kafir to the suffrage, and this has been done in a few instances. As stated in Chapter XVIII., the rapid increase of Indian immigrants in that colony alarmed the whites, and led to the passing, in 1896 , of an act which will practically debar these immigrants from political rights, as coming from a country in which no representative institutions exist. Thus Natal also has managed to exclude coloured people without making colour the nominal ground of disability. I need hardly say that whoever has the suffrage is also eligible for election to the Legislature. No person of colour is now, however, a member of either chamber in either colony.

It is easy for people in Europe, who have had no experience of the presence among them of a semicivilised race, destitute of the ideas and habits which lie at the basis of free government, to condemn the action of these colonies in seeking to preserve a decisive electoral majority for the whites. But any one who has studied the question on the spot, and especially any one who has seen the evils which in America have followed the grant of the suffrage to persons unfit for it, will form a more charitable judgment. It is indeed impolitic to exclude people merely on the score of their race. There are among 
the educated Kafirs and Indians persons quite as capable as the average man of European stock, and it is wholesome that the white, too apt to despise his coloured neighbour, should be made to feel this, and that the educated coloured man should have some weight in the community as an elector, and should be entitled to call on his representative to listen to and express the demands he may make on behalf of his own race. As the number of educated and property-holding natives increases they will naturally come to form a larger element in the electorate, and will be a useful one. But to toss the gift of political power into the lap of a multitude of persons who are not only ignorant, but in mind children rather than men, is not to confer a boon, but to inflict an injury. So far as I could judge, this is the view of the most sensible natives in Cape Colony itself, and of the missionaries also, who have been the steadiest friends of their race. What is especially desirable is to safeguard the private rights of the native, and to secure for him his due share of the land, by retaining which he will retain a measure of independence. The less he is thrown into the whirlpool of party politics the better.

Let me again repeat that there is at present no serious friction between the black and the white people in South Africa. Though the attitude of most of the whites-there are, of course many exceptions-is contemptuous, unfriendly, and even suspicious, the black man accepts the superiority 
CHAP.

of the white as part of the order of nature. $\mathrm{He}$ is too low down, too completely severed from the white, to feel indignant. Even the few educated natives are too well aware of the gulf that divides their own people from the European to resent, except in specially aggravated cases, the attitude of the latter. Each race goes its own way and lives its own life.

The condition of the wild or tribal Kafirs can be much more shortly described, for they have as yet entered into few relations with the whites. They are in many different grades of civilisation, from the Basutos, an industrious and settled population, among whom Christianity has made great progress, to the fierce Matabili of the north, and the Tongas of the east coast, who remain complete savages. There are probably six millions of Kafirs living under their chiefs south of the Zambesi, many of them entirely unaffected by Europeans, with not even a white magistrate or a native commissioner to collect hut-tax; and besides these there are the Korannas (akin to the Bushmen) and Namaquas (akin to the Hottentots) of the desert country between Bechuanaland and the Atlantic. In many of the districts where a regular British or Boer Government has been established, the tribal natives are now settled in regular locations, where the land is reserved from the intrusion of Europeans. Here they live under their chiefs in the old way (see Chapter X.), and in the remoter districts continue to practise their old ceremonies. In Cape Colony 
and Natal, however, in both of which colonies there are hundreds of thousands of tribal Kafirs, the more offensive of these ceremonies are now forbidden by the Government. Nowhere is anything done for their education, except by the missionaries, who, however, receive some little assistance from the two Colonial Governments. The ancient rites and beliefs gradually decay wherever the whites come, and, except beyond the Zambesi, intertribal wars and raids have now practically ceased. Yet the tribal hatreds survive. Not long ago the Zulus and the Kosa Kafirs employed as platelayers on the Cape Government Railway fought fiercely with each other. One powerful influence is telling upon them, even where they live uncontrolled by any white Government. The diamond-mines at Kimberley, the gold-mines in the Witwatersrand and in various parts of Mashonaland and Matabililand, offer large wages for native labour, and cannot (except at Kimberley) obtain as much native labour as they need. Accordingly a steady though still insufficient stream of Kafirs sets towards these mining centres, not only from Basutoland, Natal, and Bechuanaland, but also from the Portuguese territories, where the Shangans live, and from the banks of the Zambesi. Most of the workmen remain for a few weeks or months only, and return home when they have earned as much money as will purchase two oxen, heretofore the usual price of a wife. They are paid in English coin, and thus the English twenty-shilling gold piece has become known, and to-day passes 
current in villages where no white man has yet been seen, even beyond the Zambesi, on the shores of Lake Bangweolo. With the use of coin there will come in time a desire for European goods, which, in its turn, will draw more labour toward the mines, and perhaps at last create even among the homekeeping Kafirs a disposition to till the land or raise cattle for sale. The destruction of cattle by the murrain which has been raging over the country may accelerate this change. Already wandering traders and gold-prospectors traverse regions beyond the border of civilisation; and to keep these people, who are often reckless and lawless, from injuring the natives and provoking them to take vengeance on the next white man who comes their way, is one of the greatest difficulties of the British Government, a difficulty aggravated by the absence in nearly all cases of sufficient legal evidence-for all over South Africa native evidence is seldom received against a white man. The regions in which white influence is now most active, and which will most quickly become assimilated to the two British colonies, are those through which railways are now being constructed-Bechuanaland, Matabililand, and Mashonaland. Should the mines in these countries turn out well, and means be found for replacing by new stock the cattle that have perished, these regions may in fifteen or twenty years possess a considerable population of non-tribal and semi-civilised natives. Within the next half-century it is probable that, at least in the British territories as 
far as the Zambesi, as well as in the Transvaal and Swaziland, the power of the chiefs will have practically vanished and the natives be in a position similar to that which they now hold in Natal and the greater part of Cape Colony ; that is to say, they will either dwell among the whites under the ordinary law, or will be occupying reservations under the control of a European magistrate, their old land customs having been mostly superseded and their heathen rites forbidden or disused.

The position which the whites and the blacks hold toward one another in South Africa is sufficiently similar to that of the two races in the Southern States of America to make a short comparison between the two cases instructive. There are no doubt many differences. In the United States the Southern negroes are strangers and therefore isolated, with no such reserve of black people behind them as the Kafirs have in the rest of the African continent. In South Africa it is the whites who are new-comers and isolated, and they are numerically inferior to the blacks, not, as in America, in a few particular areas (the three States of South Carolina, Mississippi, and Louisiana), but all over the country. In the whole United States the whites are to the blacks as ten to one; in Africa south of the Zambesi it is the blacks who are ten to one to the whites. Or if we compare the four South African colonies and republics with the fifteen old slave States, the blacks are in the former nearly four times as numerous as the whites, and the whites in the latter twice as 
CHAP.

numerous as the blacks. In point of natural capacity and force of character the Bantu races are at least equal, probably superior, to the negroes brought from Africa to North America, most of whom seem to have come from the Guinea coasts. But in point of education and in habits of industry the American negroes are far ahead of the South African; for the latter have not been subjected to the industrial training of nearly two centuries of plantation life or domestic service, while comparatively few have had any industrial contact with white workmen, or any stimulation like that which the grant of the suffrage after the War of Secession has exercised upon a large section of the American negroes, even in places where they have not been permitted to turn their legal rights to practical account. The American negroes are, moreover, all nominally Christians ; the South African Kafirs nearly all heathens. Yet, after allowing for these and other minor points of contrast, the broad fact remains that in both countries we see two races in very different stages of civilisation dwelling side by side, yet not mingling nor likely to mingle. In both countries one race rules over the other. The stronger despises and dislikes the weaker; the weaker submits patiently to the stronger. But the weaker makes in education and in property a progress which will some day bring it much nearer to the stronger than it is now.

The social and political troubles which the juxtaposition of the two races has caused in North America, and which have induced many Americans 
to wish that it were possible to transport the whole seven millions of Southern negroes back to the Niger or the Congo, have as yet scarcely shown themselves in South Africa. Neither in the British colonies nor in the Boer republics is there any cause for present apprehension. The coloured people are submissive and not resentful. They have, moreover, a certain number of friends and advocates in the legislatures of the colonies, and a certain amount of public opinion, the opinion of the best part of the community, disposed to protect them. Nevertheless, no traveller can study the colour problem in South Africa without anxiety-anxiety, not for the present, but for the future, a future in which the seeds that are now being sown will have sprung up and grown to maturity.

What is the future of the Kafirs likely to be? Though a writer may prophesy with an easy mind when he knows that the truth or error of the prophecy will not be tested till long after he has himself quitted the world, still it is right to make the usual apologies for venturing to prophesy at all. These apologies being taken as made, let us consider what is likely to come to pass in South Africa.

The Kafirs will stay where they are and form the bulk of the population all over South Africa. Some sanguine men think they will move off to the hotter north, as in America the centre of negro population has shifted southward toward the Gulf of Mexico. This is improbable, because the South African white seems resolved to rely upon natives for all the harder 
and rougher kinds of labour, not to add that, although the European can thrive and work, the Kafir is more truly the child of the soil and of the climate. And not only will he stay, but, to all appearances, he will increase faster than does the white man.

The Kafirs, now divided into many tribes and speaking many languages and dialects, will lose their present tribal organisation, their languages, their distinctive habits. Whether some sort of native lingua Franca will spring up, or whether they will all come to speak English, is doubtful ; but probably in the long run English will prevail and become the common speech of the southern half of the continent. They will also lose their heathenism (though many superstitions will survive), and will become, in name at least, Christians. Thus they will form to a far greater extent than now a homogeneous mass pervaded by the same ideas and customs.

While thus constituting one vast black community, they will probably remain as sharply marked off from the whites as they are to-day. That there will be no intermarriage may safely be assumed from the fact that mixture of blood has greatly diminished since the days of slavery, just as it has diminished in the Southern States of America. White opinion universally condemns it, and rightly, for as things are now the white race would lose more by the admixture than the coloured race would gain.

The Kafirs will be far more generally educated than they are now, and will have developed a much higher intelligence. That they will remain inferior 
to the whites in all intellectual pursuits and in most handicrafts may be concluded from American experience ; but they will doubtless be able to compete with white men in many trades, will to some extent enter the professions, will acquire property, and (assuming the law to remain as at present) will form a much larger part, though probably for a very long time a minority, of the electorate. From among them there will doubtless arise men fit to lead them for social and political purposes. A talent for public speaking is already remarked as one of their gifts.

Thus the day will arrive when South Africa will see itself filled by a large coloured population, tolerably homogeneous, using the same language, having forgotten its ancient tribal feuds, and not, like the people of India, divided by caste or by the mutual hatred of Hindus and Mussulmans. Most of this population will be poor, and it may, unless successive colonies are led off to the more thinly peopled parts of Africa, tread hard upon the means of subsistence which the land offers; I say the land, for the mines -or at least the gold-mines-will have been exhausted long before the day we are contemplating arrives.

When will that day arrive? Probably not for at least a century, possibly not for two centuries. Fast as the world moves in our time, it must take several generations to develop a race so backward as the Kafirs. Many political changes may occur before then; but political changes are not likely to make much difference to a process like this, which 
goes on under natural laws-laws that will continue to work, whatever may happen to the Boers, and whatever may be the future relations of the colonies to the mother country. It is only some great change in human thought and feeling, or some undreamt-of discovery in the physical world, that can be imagined as likely to affect the progress of the natives and the attitude of the whites toward them.

When, perhaps in the twenty-first century, the native population has reached the point of progress we have been imagining, the position may be for both races a grave or even a perilous one, if the feeling and behaviour of the whites continue to be what they are now. The present contented acquiescence of the coloured people in the dominance of the whites, and the absence of resentment at the contempt displayed toward them, cannot be expected from a people whose inferiority, though still real, will be much less palpable. And if trouble comes, the preponderance of numbers on the black side may make it more serious than it could be in the United States, where the Southern whites are the outmost fringe of an enormous white nation. These anxieties are little felt, these problems are little canvassed, in South Africa, for things which will not happen in our time or in the time of our children are for most of us as though they would never happen; and we have become so accustomed to see the unexpected come to pass as to forget that where undoubted natural causes are at work-causes whose working history has examined-a result may be 
practically certain, even though the time when and the precise form in which it will arrive may be uncertain.

There are, however, some thoughtful men in the colonies who see the magnitude of the issues involved in this native problem. They hold, so far as I could gather their views, that the three chief things to be done now are to save the natives from intoxicating liquor, which injures them even more than it does the whites, to enact good land laws, which shall keep them from flocking as a loafing proletariate into the towns, as well as just labour laws, and to give them much better opportunities than they now have of industrial education. Manual training and the habit of steady industry are quite as much needed as book education, a conclusion at which the friends of the American negro have also arrived. Beyond this the main thing to be done seems to be to soften the feelings of the average white and to mend his manners. At present he considers the native to exist solely for his own benefit. $\mathrm{He}$ is harsh or gentle according to his own temper; but whether harsh or gentle, he is apt to think of the black man much as he thinks of an $\mathrm{ox}$, and to ignore a native's rights when they are inconvenient to himself.

Could he be got to feel more kindly toward the native, and to treat him, if not as an equal, which he is not, yet as a child, the social aspect of the problem-and it is the not least serious aspectwould be completely altered. 


\section{CHAPTER XXII}

\section{MISSIONS}

THE strength and vitality of a race, and its power of holding its own in the world, depend less on the quickness of its intelligence than on the solidity of its character. Its character depends upon the moral ideas which govern its life, and on the habits in which those ideas take shape; and these, in their turn, depend very largely upon the conceptions which the race has formed of religion, and on the influence that religion has over it. This is especially true of peoples in the earlier stages of civilisation. Their social virtues, the beliefs and principles which hold them together and influence their conduct, rest upon and are shaped by their beliefs regarding the invisible world and its forces. Races in which religious ideas are vague and feeble seldom attain to a vigorous national life, because they want one of the most effective bonds of cohesion and some of the strongest motives that rule conduct. It may doubtless be said that the religion of a people is as much an effect as a cause, or, in other words, that the finer or poorer quality of a race is seen in the 
sort of religion it makes for itself, the higher races producing nobler religious ideas and more impressive mythologies, just as they produce richer and more expressive languages. Nevertheless, it remains true that a religion, once formed, becomes a potent factor in the future strength and progress of a people. Now the religious ideas of the Bantu races, as of other negroes, have been scanty, poor, and unfruitful. And accordingly, one cannot meditate upon their condition and endeavour to forecast their progress without giving some thought to the influence which better ideas, and especially those embodied in Christianity, may have upon them.

Neither the Kafirs nor the Hottentots have had a religion in our sense of the word. They had no deities, no priesthood, no regular forms of worship. They were, when Europeans discovered them, still in the stage in which most, if not all, primitive races would seem to have once been-that of fearing and seeking to propitiate nature spirits and the ghosts of the dead, a form of superstition in which there was scarcely a trace of morality. Hence the first task of the missionaries who came among them was to create a religious sense, to give them the conception of an omnipotent spiritual power outside natural objects and above man, and to make them regard this power as the source of moral ideas and the author of moral commands. To do this has been a difficult task.

Besides this constructive work, which was less needed in some other more advanced heathen races, 
the missionaries had also a destructive work to do. Though the Kafirs had no religion, they had a multitude of superstitious rites and usages closely intertwined with the whole of their life and with what one may call their political system. These usages were so repugnant to Christian morality, and often to common decency, that it became necessary to attack them and to require the convert to renounce them altogether. Renunciation, however, meant a severance from the life of the tribe, contempt and displeasure from the tribesmen, and possibly the loss of tribal rights. These were evils which it required courage and conviction to face, nor had the missionary any temporal benefits to offer by way of compensation. There was, however, very little direct persecution, because there were no gods who would be incensed, and the witch-doctors were less formidable opponents than a regular priesthood would have been. The chiefs were often friendly, for they recognised the value of missionary knowledge and counsel. Even the ferocious Mosilikatze showed kindness to Robert Moffat, and Livingstone complained far more of the Boers than he ever did of Kafir enemies. Lo Bengula protected the missionaries; Gungunhana listened, and made his chiefs listen, to their discourses, though his nearest approach to conversion was his expression of detestation for Judas Iscariot. But it rarely befell that a chief himself accepted Christianity, which would have meant, among other things, the departure of all his wives but one, and possibly the loss of his hold upon 
his tribe. All these things being considered, it need excite no surprise that the gospel should have made comparatively little progress among the wild or tribal Kafirs.

It has been preached to them for nearly a century, by German (chiefly, I think, Moravian) and French, as well as by English, Scottish, and American missionaries. At present there are not a few British societies and denominations in the field. The French Protestants have done some excellent work, especially in Basutoland, and have also stations near the east coast and on the Upper Zambesi. There are also French Roman Catholic missions, mostly in the hands of Jesuit fathers, many of whom are men of learning and ability. Between the Roman Catholics, the Protestant Episcopalians (Church of England), and the missionaries of the English Nonconformists and Scottish or French Presbyterians there is little intercourse and no coöperation. Here, as in other mission fields, the absence of these things puzzles the native. I was told of an English (Protestant Episcopal) clergyman who made it one of his prime objects to warn the Kafirs against attending the services of the French Protestant missionaries, whom he apparently regarded as outside the pale of the true church. In the Boer republics there are fewer missions in proportion to the number of natives than in British territories, but no district, except the deserts of the west, seems to be wholly unprovided for, and in some cases stations have 
been pushed far beyond the limits of European administration, as, for instance, among the Barotse who dwell north of the Upper Zambesi. The native congregations are usually small, and the careers of the converts not always satisfactory. This is so natural that it is odd to find Europeans, and most conspicuously those whose own life is not a model of Christian morality, continually growling and sneering at the missionaries because their converts do not all turn out saints. The savage is unstable in character, and baptism does not necessarily extinguish either his old habits or the hold which native superstitions have upon him. It is in this instability of his will, and his proneness to yield to drink or some other temptation, rather than in his intellect, that the weakness of the savage lies. And a man with hundreds of generations of savagery behind him is still, and must be, in many respects a savage, even though he reads and writes, and wears European clothes, and possibly even a white necktie. The Kafirs are not such bad Christians as the Frankish warriors were for two or three generations after the conversion of Clovis. We must wait for several generations before we can judge fairly of the influence of his new religion upon the mind of a Kafir whose ancestors had no religion at all, and were ruled by the lowest forms of superstition.

These facts are better recognised by the missionaries to-day than they were sixty years ago, and they have in consequence made some changes in 
their methods. They are no longer so anxious to baptize, or so apt to reckon success by the number of their converts. They are more cautious in ordaining native pastors. The aid of such pastors is indispensable, but the importance of the example which the native preacher or teacher sets makes it necessary to be careful in selection. The dogma of the equality of the black man and the white, which was warmly insisted on in the old days, and often roused the wrath of the Boers, has now been silently dropped. It was a dogma wholesome to inculcate so far as equality of protection was concerned, but its wider application led the early philanthropists of South Africa, as it led their excellent contemporaries, the Abolitionists of America, to some strange conclusions. Perceiving that other influences ought to go hand in hand with religion in helping the natives forward, the missionaries now devote themselves more than formerly to secular instruction, and endeavour to train the people to habits of industry. The work of education is indeed entirely in their hands. Special mention is due to one admirable institution, that which was founded by the Free Church of Scotland at Lovedale, in the Eastern Province, not far from King William's Town, nearly fifty years ago. Conducted on wholly non-sectarian lines, it receives coloured people, together with some whites, not only from the Colony, but from all parts of Africa-there are even Galla boys from the borders of Abyssinia in it-and gives an excellent education, fitting young men and women not only for 
the native ministry, but for the professions; and it is admitted even by those who are least friendly to missionary work to have rendered immense services to the natives. I visited it, and was greatly struck by the tone and spirit which seemed to pervade it, a spirit whose results are seen in the character and careers of many among its graduates. A race in the present condition of the Kafirs needs nothing more than the creation of a body of intelligent and educated persons of its own blood, who are able to enter into the difficulties of their humbler kinsfolk and guide them wisely. Dr. Stewart, who has directed the institution for many years, possesses that best kind of missionary temperament, in which a hopeful spirit and an inexhaustible sympathy are balanced by Scottish shrewdness and a cool judgment.

One of the greatest among the difficulties which confront the missionaries is to know how to deal with polygamy, a practice deeply rooted in Kafir life. A visitor from Europe is at first surprised to find how seriously they regard it, and asks whether the example of the worthies of the Old Testament does not make it hard for them to refuse baptism to the native who seeks it, though he has more than one wife. The clergy of the Church of England, however, and those of the French Protestant Churchand I think other missionaries also-are unanimous in holding that, although they may properly admit a polygamist as a catechumen, they should not baptize such a one ; and they say that the native pastors 
hold this view even more strongly than they do themselves. Polygamy is so bound up with heathen customs, and exerts, in their view, so entirely baneful an influence upon native society, that it must be at all hazards resisted and condemned. ${ }^{1}$ One is reminded of the Neoplatonic philosophers, the last professors of the Platonic academy at Athens, who in the sixth century of our era sought an asylum from Christian persecution at the court of Chosroes Anurshirwan, in Persia. They forced themselves to tolerate the other usages of the people among whom they came, but polygamy was too much for them, and rather than dwell among those who practised it, they returned to the unfriendly soil of the Roman Empire.

The missionaries, and especially those of the London Missionary Society, played at one time a much more prominent part in politics than they now sustain. Within and on the borders of Cape Colony they were, for the first sixty years of the present century, the leading champions of the natives, and as they enjoyed the support of an active body of opinion in England and Scotland, they had much influence in Parliament and with the Colonial Office. Outside the Colony they were often the principal advisers of the native chiefs (as their brethren were at the same time in the islands of the Pacific), and held a place not unlike that of the bishops in Gaul in the fifth century of our era. Since, in advocating

1 After listening to their arguments, I did not venture to doubt that they were right. 
the cause of the natives, they had often to complain of the behaviour of the whites, and since, whenever a chief came into collision with the emigrant Boers or with colonial frontiersmen, they became the channel by which the chief stated his case to the British Government, they incurred the bitter hostility of the emigrant Boers and some dislike even in the colony. To this old cause much of the unpopularity that still attaches to them seems due. Unpopular they certainly are. They are reproached with the paucity of their converts, and that by white men whose own treatment of the Kafirs might well make the white man's religion odious to a native. They are also accused of abusing their position to enrich themselves by trade with the Kafirs. This abuse has sometimes occurred, and clearly ought to be checked by the home societies. But probably it does not disgust the wandering white trader any more than the fact that the missionary often warns the native against the exorbitant prices which the trader demands for his goods. They are blamed for making the converted Kafir uppish, and telling him that he is as good as a white man, an offence which has no doubt been often committed. A graver allegation, to which Mr. Theal has given some countenance in his historical writings, is that they used to bring groundless or exaggerated charges against the Boer farmers, and always sided with the natives, whatever the merits of the case. I do not venture to pronounce on the truth of this allegation, which it would take much time and labour to sift. As there have 
been some few missionaries whose demeanour was not creditable to their profession, so there have doubtless been instances in which partisan ardour betrayed them into exaggerations. But whoever remembers that but for the missionaries the natives would have lacked all local protection, and that it was only through the missionaries that news of injustice or cruelty practised on a native could reach the ears of the British Government, will look leniently on the errors of honest zeal, and will rejoice that ministers of religion were found to champion the cause of the weaker race and keep the home Government alive to a sense of one of its first duties.

Notwithstanding the slowness of the progress hitherto made, the extinction of heathenism in South Africa may be deemed certain, and certain at no distant date. There is here no ancient and highly organised system of beliefs and doctrines, such as Hinduism and Islam are in India, to resist the solvent power which European civilisation exerts. In forty years there will probably be no more pagan rites practised in Cape Colony. In eighty years there will be none in Matabililand, or perhaps even sooner, if the gold-reefs turn out well; for though a mining-camp is not a school of Christianity, it is a destroyer of paganism. Already I found, in traversing Mashonaland, that the poor ghosts were ceasing to receive their accustomed offerings of native beer.

What will happen when heathenism and the tribal system have vanished away? Such morality, such principles of manly conduct as the natives 
now have, are bound up with their ghost-worship and still more with their tribal system, which prescribes loyalty to the chief, courage in war, devotion to the interests of the tribe or clan. When these principles have disappeared along with the tribal organisation, some other principles, some other standard of duty and precepts of conduct, ought to be at hand to replace them. Where are such precepts to be found, and whence are the motives and emotions to be drawn which will give the new precepts a power to command the will? Although the Kafirs have shown rather less aptitude for assimilating Christian teaching than some other savage races have done, there is nothing in the experience of the missions to discourage the hope that such teaching may come to prevail among them, and that through it each generation may show a slight moral advance upon that which has gone before. As the profession of Christianity will create a certain link between the Kafirs and their rulers which may soften the asperity which the relations of the two races now wear, so its doctrines will in time give them a standard of conduct similar to that accepted among the whites, and an ideal which will influence the superior minds among them. So much may certainly be said: that the Gospel and the mission schools are at present the most truly civilising influences which work upon the natives, and that upon these influences, more than on any other agency, does the progress of the coloured race depend. 


\section{CHAPTER XXIII}

SOCIAL CHARACTERISTICS OF THE TWO BRITISH COLONIES

The two South African colonies have not yet had time to develop new and distinctive types of life and character. Though Cape Colony is nearly as old as Massachusetts or Virginia, it has been less than a century under British rule, and the two diverse elements in its population have not yet become blent into any one type that can be said to belong to the people as a whole. One must therefore describe these elements separately. The Dutch are almost all country folk, and the country folk are (in Cape Colony) mostly Dutch. Some, especially near Cape Town, are agriculturists, but many more are ranchmen or sheep-masters. They are a slow, quiet, well-meaning hospitable people, extremely conservative in their opinions as well as their habits, very sparing, because they have little ready money, very suspicious, because afraid of being outwitted by the English traders, and many of them so old-fashioned in their theory of the universe as to object to legislation against sheep 
scab, because they regard it as a visitation of Providence, to be combated only by repentance and not by ordinary human means. The women are usually ill-educated and often unattractive; but they have strong characters. Nothing was more remarkable in the wars of the emigrant Boers against the Kafirs than the courage and devotion which the women displayed. That love of cleanliness for which their kinsfolk in Holland are famous has vanished under the conditions of a settler's life and the practice of using negro servants, and they are now apt to be slatternly. These country folk live in a simple, old-fashioned way, loving solitude and isolation, yet very hospitable, and enjoying the rare occasions on which they meet for festivities at one another's farm-houses. Such meetings are almost their only recreations, for hunting is less attainable now that the larger game has disappeared, and they care nothing for the intellectual pleasures of reading or art or music. Education is beginning to spread among them, but it has not yet done much to quicken their minds or give them new interests. The population is so extremely thin, the towns so few and so small, that it is not surprising that a people who came out from the least educated strata of society in Holland should, under the difficult conditions of a settler's life, have remained at a low level of mental culture. They would probably have been still more backward, and have produced fewer men of ability, but for the infusion of French Huguenot blood, which 
still proclaims itself in the names of some of the leading families.

Compared to the Dutch, the English are recent immigrants. They have all arrived within the present century, and few of them can point to grandfathers born in South Africa. Partly for this reason, partly from their desire to be unlike the Dutch, they have remained markedly English, both in their speech, in their ideas, and, so far as the differences of climate permit, in their way of life. Nevertheless, they have been affected by the Dutch. They have taken from the latter the aversion to field-labour, the contempt for the blacks, the tendency to prefer large pastoral farms to agriculture, and, in some districts, a rather sleepy and easy-going temperament. Even in Mashonaland I was told that the English ranchmen were apt to fall into the habits of their Boer neighbours. They form the large majority of the town population, for not only the seaports, but also such inland places as Graham's Town, King William's Town, and Kimberley are quite English, and nearly all the commerce and finance of the country are in their hands. They have more enterprise than the Dutch, and are much less antiquated in their ideas, so it is to them that the profits of the new mining ventures have chiefly fallen, so far as these have not been appropriated by keener and more ingenious adventurers from Europe, mostly of Semitic stock.

There has been hardly any Irish immigration; 
CHAP.

and though one meets many Scotchmen among the bankers and merchants, the Scottish element seems smaller than in Ontario or most of the Australasian colonies. Many settlers have come from Germany, but these have now become blended with the English. There are no better colonists than the Germans; and indeed the Europeans whom the last ninety years have brought have been mostly of excellent stocks, superior to the mid-European races that have lately inundated the United States.

Though the English and the Dutch form distinct social elements which are not yet fused, and though these elements are now politically opposed, there is no social antagonism between the races. The Englishman will deride the slowness of the Dutchman, the Dutchman may distrust the adroitness or fear the activity of the Englishman, but neither dislikes nor avoids the other. Neither enjoys, or even pretends to, any social superiority, and hence neither objects to marry his son or his daughter to a member of the other race. Both are, as a rule, in fairly easy circumstances; that is to say, nearly everybody has enough, and till lately hardly any one had more than enough. Within the last few years, however, two changes have come. The diamond-mines and the gold-mines have given vast riches to a small number of persons, some halfdozen or less of whom continue to live in the colony, while the others have returned to Europe. These great fortunes are a disturbing element, giving an undue influence to their possessors, and 
exciting the envy or emulation of the multitude. The other change is the growth of a class of people resembling the "mean whites" of the Southern States of America, loafers and other lazy or shiftless fellows who hang about and will not take to any regular work. I heard them described and deplored as a new phenomenon, but gather that they are not yet numerous. Their appearance, it is to be feared, is the natural result of that contempt for hard, unskilled labour which the existence of slavery inspired in the whites; and they may hereafter constitute, as they now do in the Southern States of America, the section of the population specially hostile to the negro, and therefore dangerous to the whole community.

To an Englishman or American who knows how rapidly his language has become the language of commerce over the world; how it has almost extinguished the ancient Celtic tongues in Scotland and Ireland; how quickly in the United States it has driven Spanish out of the South West, and has come to be spoken by the German, Scandinavian, and Slavonic immigrants whom that country receives, it is surprising to find that Dutch holds its ground stubbornly in South Africa. It is still the ordinary language of probably one-half of the people of Cape Colony (although most of these can speak some English) and of three-fourths of those in the Orange Free State, though of a minority in Natal. Englishmen settling in the interior usually learn it for the sake of talking to their Dutch neighbours, 
who are slow to learn English; and English children learn it from the coloured people, for the coloured people talk it far more generally than they do English ; in fact, when a native (except in one of the coast towns) speaks a European tongue, that tongue is sure to be Dutch. Good observers told me that although an increasing number of the Africanders (i.e., colonists born in Africa) of Dutch origin now understand English, the hold of Dutch is so strong that it will probably continue to be spoken in the Colony for two generations at least. Though one must call it Dutch, it differs widely from the cultivated Dutch of Holland, having not only preserved some features of that language as spoken two centuries ago, but having adopted many Kafir or Hottentot words, and having become vulgarised into a dialect-called the Taal-which is almost incapable of expressing abstract thought or being a vehicle for any ideas beyond those of daily life. In fact, many of the Boers, especially in the Transvaal, cannot understand a modern Dutch book, hardly even a newspaper. This defect might give English a great advantage if the Boers wished to express abstract ideas. But they have not this wish, for they have no abstract ideas to express. They are a people who live in the concrete.

The rise of great fortunes, which I have noted, has been too recent and too exceptional a phenomenon to have affected the generally tranquil and even tenor of South African social life. Among 
both Dutch and English months and years flow smoothly on. Few new immigrants enter the rural districts or the smaller towns; few new enterprises are started; few ambitions or excitements stir the minds of the people. The Witwatersrand goldfield is, of course, a startling exception, but it is an exception which tends to perpetuate the rule, for, by drawing off the more eager and restless spirits, it has left the older parts of both the colonies more placid than ever. The general equality of conditions has produced a freedom from assumption on the one hand, and from servility on the other, and indeed, a general absence of snobbishness, which is quite refreshing to the European visitor. Manners are simple, and being simple, they are good. If there is less polish than in some countries, there is an unaffected heartiness and kindliness. The Dutch have a sense of personal dignity which respects the dignity of their fellows, and which expresses itself in direct and natural forms of address. An experienced observer dilated to me on the high level of decorum maintained in the Cape Parliament, where scenes of disorder are, I believe, unknown, and violent language is rare. One expects to find in all colonies a sense of equality and an element of sans gêne in social intercourse. But one usually finds also more roughness and more of an offhand, impatient way of treating strangers than is visible in South Africa. This may be partly due to the fact that people are not in such a hurry as they are in most new countries. They have plenty of time for everything. 
The climate disinclines them to active exertion. There is little immigration. Trade, except in the four seaports, ${ }^{1}$ is not brisk, and even there it is not brisk in the American sense of the word. The slackness of the black population, which has to be employed for the harder kinds of work, reacts upon the white employer. I have visited no new Englishspeaking country where one so little felt the strain and stress of modern life. This feature of South African society, though it implies a slow material development, is very agreeable to the visitor, and I doubt if it be really an injury to the ultimate progress of the country. In most parts of North America, possibly in Australia also, industrial development has been too rapid, and has induced a nervous excitability and eager restlessness of temper from which South Africa is free. Of course, in saying this, I except always the mining districts, and especially the Witwatersrand, which is to the full as restless and as active as San Francisco or Melbourne.

The comparative ease of life disposes the English part of the population to athletic sports, which are pursued with almost as much avidity as in Australia. Even one who thinks that in England the passion for them has gone beyond all reasonable limits, and has become a serious injury to education and to the taste for intellectual pleasures, may find in the character of the climate a justification for the devotion to cricket, in particular, which strikes him in South Africa. Now that the wild animals have

${ }^{1}$ Cape Town, Port Elizabeth, East London and Durban. 
become scarce, hunting cannot be pursued as it once was, and young people would have little incitement to physical exertion in the open air did not the English love of cricket subsist in the schools and colleges. Long may it subsist !

The social conditions I have been describing are evidently unfavourable to the development of literature or science or art. Art has scarcely begun to exist. Science is represented only by a few naturalists in Government employment, and by some intelligent amateur observers. Researches in electricity or chemistry or biology require nowadays a somewhat elaborate apparatus, with which few private persons could provide themselves, and which are here possessed only by one or two public institutions. English and American writers have hitherto supplied the intellectual needs of the people, and the established reputation of writers in those countries makes competition difficult to a new colonial author. The towns are too small, and their inhabitants too much occupied in commerce, to create groups of highly educated people, capable of polishing, whetting, and stimulating one another's intellects. There are few large libraries, and no fully equipped university to train young men in history or philosophy or economics or theology. Accordingly, few books are composed or published, and, so far as I know, only three South African writers have caught the ear of the European public. One of these was Robert Pringle, a Scotchman, whose poems, written sixty or seventy years ago, possess consider- 
able merit, and one of which, beginning with the line,

Alone in the desert I love to ride,

remains the most striking picture of South African nature in those early days when the wilderness was still filled with wild creatures. Another, Miss Olive Schreiner (now Mrs. Cronwright-Schreiner), has attained deserved fame. A third, Mr. Scully, is less known in England, but his little volume of Kafir Tales is marked by much graphic power and shows insight into native character.

These three writers, and indeed all the writers of merit, belong to the English or Anglified section of the population. The Dutch section is practically disqualified by its language (which, be it remembered, is not the language of Holland, but a debased dialect) from literary composition, even were it otherwise disposed to authorship. Literature will always, I think, remain English in character, bearing few or no traces of the Dutch element in the people. But otherwise things are likely to change in a few years. The conditions which have been described as unfavourable to intellectual production are not necessarily permanent, and the time will probably come when the Europeans of South Africa will emulate their kinsfolk at home or in North America in literary and artistic fertility. The materials for imaginative work, whether in poetry or in prose, lie ready to their hand. The scenery deserves some great native landscape-painter, and such a genius will, no doubt, one day arise. 
Journalism has now everywhere become, in point of quantity, the most important part of literature. The South African newspapers impress a visitor favourably. Several of them are written with great ability, and they are comparatively free from that violence of invective, that tawdriness of rhetoric, and that proneness to fill their columns with criminal intelligence which are apt to be charged against the press in some other new countries. No journal seems to exert so great a political power as is wielded by several of the Australian dailies. As might be expected, the Press is chiefly English, that language having sixty-one papers, against seventeen printed in Dutch and twenty-three in both languages.

Although the dispersion of the small European population over an exceedingly wide area makes it difficult to provide elementary schools everywhere, ${ }^{1}$ education is, among the whites, well cared for, and in some regions, such as the Orange Free State, the Boer element is just as eager for it as is the English. Neither are efficient secondary schools wanting. That which is wanting, that which is urgently needed to crown the educational edifice, is a properly equipped teaching university. There are several colleges which provide lectures, ${ }^{2}$ and the Cape University holds examinations and confers degrees; but to erect over these colleges a true university

1 In Cape Colony 28.82 of the male and 28.02 of the female population could not read or write (in I891).

${ }^{2}$ Five colleges receive Government grants. 
with an adequate teaching staff seems to be as difficult an enterprise at the Cape as it has proved to be in London, where twelve years have now been spent in vain efforts to establish a teaching university. It is strange to find that in a new country, where the different religious bodies live on good terms with one another, one of the chief obstacles in the way is the reluctance of two of the existing colleges, which have a denominational character, to have an institution superior to them set up by the State. The other obstacles are the rivalry of the eastern province with the western, in which, at Cape Town, the natural seat of a university would be found, and the apathy or aversion of the Dutch section of the people. Some of them do not care to spend public money for a purpose whose value they cannot be made to understand. Others, knowing that a university would necessarily be mainly in English hands and give instruction of an English type, fear to establish what would become another Anglifying influence. Thus several small colleges go on, each with inadequate resources, and the Cape youth who desires to obtain a first-rate education is obliged to go to Europe for it. He cannot even get a full course of legal instruction, for there is no complete law school. It is no doubt well that a certain number of young men should go to Europe and there acquire a firsthand knowledge of the ideas and habits of the Old World; but many who cannot afford the luxury of a European journey and residence remain without the kind of instruction to which their natural gifts 
entitle them, and the intellectual progress of the country suffers. Were Cape Colony somewhere in the United States, a millionaire would forthwith step in, build a new university, and endow it with a few millions of dollars. But South Africa is only just beginning to produce great fortunes; so the best hope is that some enlightened and tactful statesman may, by disarming the suspicions and allaying the jealousies I have described, succeed in uniting the existing colleges, and add to their scanty revenues an adequate Government grant. This may possibly be effected. But the jealousies and ambitions which those who control an institution feel for it are often quite as tenacious as is the selfishness of men where their own pockets are concerned; and since these jealousies disguise themselves under a cloak of disinterestedness, it is all the more hard to overcome them by the pressure of public opinion.

One other intellectual force remains to be mentioned-that of the churches. In the two British colonies no religious body receives special State recognition or any grants from the State. ${ }^{1}$ All are on an equal footing, just as in Australia and in North America. In the two Boer republics the Dutch Reformed Church is in a certain sense the State church. In the Transvaal it is recognised as such by the Grondwet ("Fundamental Law"), and receives a Government subvention. Members of other churches were at one time excluded from the suffrage and

1 The small grant for religious purposes made in Cape Colony was being reduced, and was to expire shortly. 
CHAP.

from all public offices, and even now Roman Catholics are under some disability. In the Orange Free State the Dutch Reformed Church receives public aid, but I think this is given, to a smaller extent, to some other denominations also, and no legal inequalities based on religion exist. In these two republics nearly the whole of the Boer population, and in the Free State a part even of the English population, belong to the Dutch Reformed communion, which is Presbyterian in government and Calvinistic in theology. In the British colonies the Protestant Episcopal Church (Church of England) comes next after the Dutch Reformed, which is much the strongest denomination; but the Wesleyans are also an important body, and there are, of course, also Congregational and Baptist churches. The Presbyterians seem to be less numerous (in proportion to the population) than in Canada or Australia, not merely because the Scottish element is less numerous, but also because many of the Scottish settlers joined the Dutch Reformed Church as being akin to their own in polity and doctrine. The comparative paucity of Roman Catholics is due to the paucity of Irish immigrants. ${ }^{1}$ These bodies live in perfect harmony and good feeling one with another, all frankly accepting the principle of equality, none claiming any social pre-eminence, and none,

1 The census of r89r gives the numbers as follows: Dutch Reformed Church, 306,000; Church of England, 139,000; Wesleyans, ro6,000; Congregationalists, 69,000; Presbyterians, 37,000; Roman Catholics, 17,000; Mohammedans, I 5,000. 
so far as I could learn, attempting to interfere in politics. Both the bishops and the clergy of the Church of England (among whom there are many gifted men) are, with few exceptions, of marked High-church proclivities, which, however, do not appear to prevail equally among the laity. The Dutch Reformed Church has been troubled by doubts as to the orthodoxy of many of its younger pastors who have been educated at Leyden or Utrecht, and for a time it preferred to send candidates for the ministry to be trained at Edinburgh, whose theological schools inspired less distrust. It is itself in its turn distrusted, apparently without reason, by the still more rigid Calvinists of the Transvaal.

One curious feature of South African society remains to be mentioned, which impressed me the more the longer I remained in the country. The upper stratum of that society, consisting of the well-to-do and best educated people, is naturally small, because the whole white population of the towns is small, there being only four towns that have more than ten thousand white residents. But this little society is virtually one society, though dispersed in spots hundreds of miles from one another. Natal stands rather apart, and has very little to do either socially or in the way of business with Cape Colony, and not a great deal even with the Transvaal. So too the four or five towns of the eastern province of Cape Colony form a group somewhat detached, and though the "best people" in each of them know all about the "best people" in Cape Town, they are not 
in close touch with the latter. But Cape Town, Kimberley, Bloemfontein, Johannesburg, and Pretoria, the five most important places (excluding the Natal towns), are for social purposes almost one city, though it is six hundred and fifty miles from Cape Town to Kimberley and one thousand miles from Cape Town to Johannesburg. All the persons of consequence in these places know one another and follow one another's doings. All mix frequently, because the Cape Town people are apt to be called by business to the inland cities, and the residents of the inland cities come to Cape Town for sea air in the summer, or to embark thence for Europe. Where distances are great, men think little of long journeys, and the fact that Cape Town is practically the one port of entrance and departure for the interior, so far as passengers are concerned, keeps it in constant relations with the leading men of the interior, and gives a sort of unity to the upper society of the whole country, which finds few parallels in any other part of the world. Johannesburg and Cape Town in particular are, for social purposes, in closer touch with each other than Liverpool is with Manchester or New York with Philadelphia. When one turns to the map it looks a long way from the Cape to the Witwatersrand ; but between these places most of the country is a desert, and there is only one spot, Bloemfontein, that deserves to be called a town. So I will once more beg the reader to remember that though South Africa is more than half as large as Europe, it is, measured by population, a very small country. 


\section{CHAPTER XXIV}

POLITICS IN THE TWO BRITISH COLONIES

THE circumstances of the two South African colonies are so dissimilar from those of the British colonies in North America and in Australasia as to have impressed upon their politics a very different character. I do not propose to describe the present political situation, for it may have changed before these pages are published. It is only of the permanent causes which give their colour to the questions and the movements of the country that I shall speak, and that concisely.

The frame of government is, in Cape Colony as well as in Natal, essentially the same as in the other self-governing British colonies. There is a Governor, appointed by the home Government, and responsible to it only, who plays the part which belongs to the Crown in Great Britain. He is the nominal head of the executive, summoning and proroguing the Legislature, appointing and dismissing ministers, and exercising, upon the advice of his ministers, the prerogative of pardon. There is a cabinet of five persons, including the heads of the chief administra- 
CHAP.

tive departments, who are the practical executive of the Colony, and are responsible to the Legislature, in which they sit, and at whose pleasure they hold their offices. There is a Legislature consisting of two houses - an Assembly, with seventy-nine, and a Legislative Council, with twenty-three, members. In Cape Colony (for of the arrangements in Natal I have spoken in a previous chapter) both houses are elected on the same franchise-a low one; but the districts for the election of members of the Council are much larger, and therefore fewer, than the Assembly districts, so the former body is a small and the latter a comparatively numerous one. ${ }^{1}$ The rights and powers of both houses are theoretically the same, save that money bills originate in the Assembly; but the Assembly is far more powerful, for the ministry holds office only so long as it has the support of a majority in that body, whereas it need not regard a hostile vote in the Council. Ministers have the right of speaking in both houses, but can, of course, vote only in the one of which they are members by popular election. If there happens not to be a minister who has a seat in the Council (as is the case at present), it is usual for the cabinet to allot one to be present in and look after that chamber for the day.

This cabinet system, as it is called, works pretty smoothly, on lines similar to that English original whence it is copied. The most interesting pecu-

1 There are for the Council seven electoral provinces, each of which returns three members to the Council, besides one for Griqualand West and one for British Bechuanaland. 
liarity is the Cape method of forming the smaller house. In England the Upper House is composed of hereditary members; in the Canadian Confederation, of members nominated for life-both of them methods which are quite indefensible in theory. Here, however, we find the same plan as that which prevails in the States of the North American Union, all of which have senates elected on the same franchise, and for the same term, as the larger house, but in more extensive districts, so as to make the number of members of the senate or second chamber smaller. Regarding the merits of the Cape scheme, I heard different views expressed. Nobody seemed opposed in principle to the division of the Legislature into two houses, but many condemned the existing Council as being usually composed of second-rate men, and apt to be obstructive in its tendencies. Some thought the Council was a useful part of the scheme of government, because it interposed delay in legislation and gave time for reflection and further debate. One point came out pretty clearly. No difficulty is deemed to arise from the fact that there exist two popularly elected houses equally entitled to control the administration, ${ }^{1}$ for custom has settled that the Assembly or larger house is that whose vote determines the life of a ministry. But it follows from this circumstance

1 Some friction has, however, arisen from the right claimed by the Council of amending money bills, especially for the purpose (one is told) of securing grants to the electoral provinces they represent. 
that all the most able and ambitious men desire a seat in the more powerful chamber, leaving the smaller house to those of less mark. This is the exact reverse of what has happened in the United States, where a seat in the Senate is more desired than one in the House; but it is a natural result of the diverse arrangements of the two countries, for in the Federal Government the Senate has some powers which the House of Representatives does not enjoy, while in each of the several States of the Union, although the powers of the two houses are almost the same, the smaller number of each Senate secures for a senator somewhat greater importance than a member of the larger body enjoys. The Cape Colony plan of letting a minister speak in both houses works very well, and may deserve to be imitated in England, where the fact that the head of a department can explain his policy only to his own House has sometimes caused inconvenience.

So much for the machinery. Now let us note the chief points in which the circumstances of Cape Colony and of Natal (for in these respects both colonies are alike) differ from those of the other self-governing colonies of Britain.

The population is not homogeneous as regards race, but consists of two stocks, English and Dutch. These stocks are not, as in Canada, locally separate, but dwell intermixed, though the Dutch element predominates in the western province and in the interior generally, the English in the eastern province and at the Kimberley diamond-fields. 
The population is homogeneous as regards religion, for nearly all are Protestants, and Protestants of much the same type. Race difference has fortunately not been complicated, as in Canada, by ecclesiastical antagonisms.

The population is homogeneous as respects material interests, for it is wholly agricultural and pastoral, except a few merchants and artisans in the seaports, and a few miners at Kimberley and in Namaqualand. Four-fifths of it are practically rural, for the interests of the small towns are identical with those of the surrounding country.

The population is not only rural, but scattered more thinly over a vast area than in any other British colony, except north-western Canada, and parts of Australasia. In Natal there are only two white men to the square mile, and in Cape Colony less than two. Nor is this sparseness incidental, as in North America, to the early days of settlement. It is due to a physical condition-the thinness of the pasture-which is likely to continue.

Below the white citizens, who are the ruling race, there lies a thick stratum of coloured population, numerically larger, and likely to remain so, because it performs all the unskilled labour of the country. Here is a condition which, though present in some of the Southern States of America, is fortunately absent from all the self-governing colonies of Britain, and indeed caused Jamaica to be, some time ago, withdrawn from that category.

The conjunction of these circumstances marks 
off South Africa as a very peculiar country, where we may expect to find a correspondingly peculiar political situation. Comparing it to other colonies, we may say that the Cape and Natal resemble Canada in the fact that there are two European races present, and resemble the Southern States of America in having a large mass of coloured people beneath the whites. But South Africa is in other respects unlike both; and although it is situated in the southern hemisphere, it bears little resemblance to Australia.

Now let us see how the circumstances above described have determined the political issues that have arisen in Cape Colony.

Certain issues are absent which exist, not only in Europe and the United States, but also in Australia and in Canada. There is no antagonism of rich and poor, because there are very few poor and still fewer rich. There is no working-man's or labour party, because so few white men are employed in handicrafts. There is no Socialist movement, nor is any likely soon to arise, because the mass of workers, to whom elsewhere Socialism addresses itself, is mainly composed of black people, and no white would dream of Collectivism for the benefit of blacks. Thus the whole group of labour questions, which bulks so largely in modern industrial States, is practically absent, and replaced by a different set of class questions, to be presently mentioned.

There is no regularly organised Protectionist 
party, nor is the protection of native industry a "live issue" of the first magnitude.

The farmers and ranchmen of Cape Colony no doubt desire to have custom duties on food-stuffs that will help them to keep up prices, and they have got such duties. But the scale is not very high, and as direct taxation is difficult to raise in a new country with a scattered population, the existing tariff, which averages twelve and a half per cent. ad valorem (but is further raised by special rates on certain articles), may be defended as needed, at least to a large extent, for the purposes of revenue. Natal has a lower tariff, and is more favourable in principle to free-trade doctrine. Manufactures have been so sparingly developed in both colonies that neither employers nor workmen have begun to call for high duties against foreign goods. Here, therefore, is another field of policy, important in North America and Australia, which has given rise to comparatively little controversy in South Africa.

As there is no established church, and nearly all the people are Protestants, there are no ecclesiastical questions, nor is the progress of education let and hindered by the claims of sects to have their respective creeds taught at the expense of the State.

Neither are there any land questions, such as those which have arisen in Australia, for there has been land enough for those who want to have it, while few agricultural immigrants arrive to increase the demand. Moreover, though the landed estates are large, their owners are not rich, and excite no 
envy by their possession of a profitable monopoly. If any controversy regarding natural resources arises, it will probably turn on the taxation of minerals. Some have suggested that the State should appropriate to itself a substantial share of the profits made out of the diamond and other mines, and the fact that most of those profits are sent home to shareholders in Europe might be expected to make the suggestion popular. Nevertheless, the suggestion has not, so far, "caught on," to use a familiar expression, partly, perhaps, because Cape Colony, drawing sufficient income from its tariff and its railways, has not found it necessary to hunt for other sources of revenue.

Lastly, there are no constitutional questions. The suffrage is so wide as to admit nearly all the whites, and there is, of course, no desire to go lower and admit more blacks. The machinery of government is deemed satisfactory ; at any rate, one hears of no proposals to change it, and, as will be seen presently, there is not in either colony a wish to alter the relations now subsisting between it and the mother country.

The reader may suppose that if all these grounds of controversy, familiar to Europe, and some of them now unhappily familiar to the new democracies also, are absent, South Africa enjoys the political tranquillity of a country where there are no factions, and the only question is how to find the men best able to promote that economic development which all unite in desiring. This is by no means the case. 
In South Africa the part filled elsewhere by constitutional questions, and industrial questions, and ecclesiastical questions, and currency questions, is filled by race questions and colour questions. Colour questions have been discussed in a previous chapter. They turn not, as in the Southern States of America, upon the political rights of the black man (for on this subject the ruling whites are in both colonies unanimous), but upon land rights and the regulation of native labour. They are not at this moment actual and pungent issues, but they are in the background of every one's mind, and the attitude of each man to them goes far to determine his political sympathies. One cannot say that there exist pronative or anti-native parties, but the Dutch are by tradition more disposed than the English to treat the native severely and, as they express it, keep him in his place. Many Englishmen share the Dutch feeling, yet it is always by Englishmen that the advocacy of the native case is undertaken. In Natal both races are equally anti-Indian.

The race question among the whites, that is to say, the rivalry of Dutch and English, would raise no practical issue were Cape Colony an island in the ocean, for there is complete political and social equality between the two stocks, and the material interests of the Dutch farmer are the same as those of his English neighbour. It is the existence of a contiguous foreign State, the South African Republic, that sharpens Dutch feeling. The Boers who remained in Cape Colony and in Natal have always 
CHAP.

retained their sentiment of kinship with those who went out in the Great Trek of 1836 , or who moved northward from Natal into the Transvaal after the annexation of Natal in 1842. Many of them are connected by family ties with the inhabitants of the two republics, and are proud of the achievements of their kinsfolk against Dingaan and Mosilikatze, and of the courage displayed at Laing's Nek and Majuba Hill against the British. They resent keenly any attempt to trench upon the independence of the Transvaal, while most of the English do not conceal their wish to bring that State into a South African Confederation, if possible under the British flag. The ministries and legislatures of the two British colonies, it need hardly be said, have no official relations with the two Dutch republics, because, according to the constitution of the British empire, such relations, like all other foreign relations, belong to the Crown, and the Crown is advised by the British Cabinet at home. In South Africa the Crown is represented for the purpose of these relations by the High Commissioner, who is not responsible in any way to the colonial legislatures, and is not even bound to consult the colonial cabinet, for his functions as High Commissioner for South Africa are deemed to be distinct from those which he has as Governor of Cape Colony. Matters relating to the two republics and their relation to the colonies are, accordingly, outside the sphere of action of the colonial legislatures, which have, in strict theory, no right to pass resolutions regarding 
them. In point of fact, however, the Cape Assembly frequently does debate, and pass resolutions on, these matters ; nor is this practice disapproved, for, as the sentiments of the Colony are an important factor in determining the action of the home Government, it is well that the British Cabinet and the High Commissioner should possess such a means of gauging those sentiments. The same thing happens with regard to any other question between Britain and a foreign Power which affects the two colonies. Questions with Germany or Portugal, questions as to the acquisition of territory in South Central Africa, would also be discussed in the colonial legislatures, just as those of Australia some years ago complained warmly of the action of France in the New Hebrides. And thus it comes to pass that though the Governments and Legislatures of the colonies have in strictness nothing to do with foreign policy, foreign policy has had much to do with the formation of parties at the Cape.

Now as to the parties themselves. Hitherto I have spoken of Natal and the Cape together, because their conditions are generally similar, though the Dutch element is far stronger in the latter than in the former. In what follows I speak of the Cape only, for political parties have not had time to grow up in Natal, where responsible government dates from I893. In the earlier days of the Cape Legislature parties were not strongly marked, though they tended to coincide with the race distinction between Dutch and English, because the western province 
CHAP.

was chiefly Dutch, and the eastern chiefly English, and there was a certain rivalry or antagonism between these two main divisions of the country. The Dutch element was, moreover, wholly agricultural and pastoral, the English party mercantile; so when an issue arose between these two interests, it generally corresponded with the division of races. Political organisation was chiefly in English hands, because the colonial Dutch had not possessed representative government, whereas the English brought their home habits with them. However, down till I 880 parties remained in an amorphous or fluid condition, being largely affected by the influence of individual leaders; and the Dutch section of the electorate was hardly conscious of its strength. In the end of that year, the rising in the Transvaal, and the War of Independence which followed, powerfully stimulated Dutch feeling, and led to the formation of the Africander Bond, a league or association appealing nominally to African, but practically to Boer, patriotism. It was not anti-English in the sense of hostility to the British connection, any more than was the French party in Lower Canada at the same time, but it was based not only on the solidarity of the Boer race over all South Africa, but also on the doctrine that Africanders must think of Africa first, and see that the country was governed in accordance with local sentiment rather than on British lines or with a view to British interests. Being Dutch, the Bond became naturally the rural or agricultural and pastoral party, and therewith inclined to a 
protective tariff and to stringent legislation in native matters. Such anti-English tint as this association originally wore tended to fade when the Transvaal troubles receded into the distance, and when it was perceived that the British Government became more and more disposed to leave the colony to manage its own affairs. And this was still more the case after the rise to power of Mr. Cecil Rhodes, who, while receiving the support of the Bond and the Dutch party generally, was known to be also a strong Imperialist, eager to extend the range of British power over the continent. At the same time, the attachment of the colonial Dutch to the Transvaal cooled down under the unfriendly policy of that republic, whose Government imposed heavy import duties on their food-stuffs, and denied to their youth the opportunities of obtaining posts in the public service of the republic, preferring to fetch Dutch-speaking men from Holland, when it could have had plenty of capable people from the Cape who spoke the tongue and knew the ways of the country. Thus the embers of Dutch and English antagonism seemed to be growing cold when they were suddenly fanned again into a flame by the fresh Transvaal troubles of December, I895, which caused the resignation of Mr. Rhodes, and the severance from him of his Dutch supporters. Too little time has elapsed since those events to make it possible to predict how parties may reshape themselves, nor is it any part of my plan to deal with current politics. Feeling still runs high, but it has not destroyed the previously 
CHAP.

friendly social relations of the races, and there is reason to hope that within a few months or years mutual confidence will be restored.

So far as I could ascertain, both local government and central government are in the two colonies, as well as in the Orange Free State, pure and honest. The judiciary is above all suspicion, and includes several distinguished men. The civil service is managed on English principles, there being no elective offices; and nothing resembling what is called the "caucus system" seems to have grown up. There are in the Cape Legislature some few members supposed to be "low-toned" and open to influence by the prospect of material gain, but, though I heard of occasional jobbing, I heard of nothing amounting to corruption. Elections are said to be free from bribery, but as they have seldom excited keen interest, this point of superiority to most countries need not be ascribed to moral causes.

Reviewing the course of Cape politics during the thirty years of responsible government, that course appears smooth when compared with the parallel current of events in the Australian colonies. There have been few constitutional crises, and no exciting struggles over purely domestic issues. This is due not merely to the absence of certain causes of strife, but also to the temper of the people, and their thin dispersion over a vast territory. In large town populations excitement grows by the sympathy of numbers, but South Africa has only five or six towns in which a public meeting of even three hundred 
citizens could be gathered. The Dutch are tardy, cautious, and reserved. The doggedness of their ancestors who resisted Philip II. of Spain lives in them still. They have a slow, tenacious intensity, like that of a forest fire, which smoulders long among the prostrate trunks before it bursts into flame. But they are, except when deeply stirred, conservative and slow to move. They dislike change so much as to be unwilling to change their representatives or their ministers. A Cape statesman told me that the Dutch members of the Assembly would often say to him: "We think you wrong in this instance, and we are going to vote against you, but we don't want to turn you out ; stay on in office as before." So President Kruger observed to me, in commenting on the frequent changes of government in England: "When we have found an ox who makes a good leader of the team, we keep him there, instead of shifting the cattle about in the hope of finding a better one"; and in saying this he expressed the feelings and habits of his race. To an Englishman the Dutch seem to want that interest in politics for the sake of politics which marks not only the English (and still more the Irish) at home, but also the English stock in North America and Australia. But this very fact makes them all the more fierce and stubborn when some issue arises which stirs their inmost mind, and it is a fact to be remembered by those who have to govern them. The things they care most about are their religion, their race ascendency over the blacks, and thei $i_{r}$ 
Dutch-African nationality as represented by their kinsfolk in the two republics. The first of these has never been tampered with; the two latter have been at the bottom of all the serious difficulties that have arisen between them and the English. That which at this moment excites them and forms the crucial issue in Cape politics is the strained condition of things which exist in the Transvaal. I propose in the following chapter to explain how that condition came about, and to sketch its salient features. 


\section{CHAPTER XXV}

THE SITUATION IN THE TRANSVAAL BEFORE THE RISING OF I 895

ThE agitation at Johannesburg, which Dr. Jameson's expedition turned into a rising, took place in December, I895. I spent some time in Pretoria and Johannesburg in the preceding month, and had good opportunities of observing the symptoms of political excitement and gauging the tendencies at work which were so soon to break out and fix the eyes of the world upon the Witwatersrand. The situation was a singular one, without parallel in history; and though I did not know that the catastrophe was so near at hand, it was easy to see that a conflict must come and would prove momentous to South Africa. Of this situation as it presented itself to a spectator who had no personal interest involved, and had the advantage of hearing both sides, I propose to speak in the present chapter.

To comprehend the position of the Transvaal Boers one must know something of their history. From the brief sketch of it given in earlier chapters (Chapters XI. and XII.) the reader will have gathered how unlike they are to any European 
people or to the people of the United States. Severed from Europe and its influences two hundred years ago, they have, in some of the elements of modern civilisation, gone back rather than forward. They were in I885, when the gold-fields were discovered, and many of them are to-day, a halfnomad race, pasturing their flocks and herds over the vast spaces of what is still a wilderness, and migrating in their waggons from the higher to the lower pastures according to the season of the year-Omnia secum

Armentarius Afer agit, tectumque laremque

Armaque, Amyclæumque canem, Cressamque pharetram.

Living in the open air, and mostly in the saddle, they are strangely ignorant and old fashioned in all their ideas. They have no literature and very few newspapers. Their religion is the Dutch and Huguenot Calvinism of the seventeenth century, rigid and stern, hostile to all new light, imbued with the spirit of the Old Testament rather than of the New. They dislike and despise the Kafirs, whom they have regarded as Israel may have regarded Amalek, and whom they have treated with equal severity. They hate the English also, who are to them the hereditary enemies that conquered them at the Cape ; that drove them out into the wilderness in 1836 ; that annexed their republic in 1877 , and thereafter broke the promises of self-government made at the time of the annexation; that stopped their expansion on the west by occupying Bechuanaland, and on the north by occupying Matabililand 
and Mashonaland; and that are now, as they believe, plotting to find some pretext for overthrowing their independence. Their usual term (when they talk among themselves) for an Englishman is "rotten egg." 1 This hatred is mingled with a contempt for those whom they defeated at Laing's Nek and Majuba Hill, and with a fear born of the sense that the English are their superiors in knowledge, in activity, and in statecraft. It is always hard for a nation to see the good qualities of its rivals and the strong points of its opponents' case ; but with the Boers the difficulty is all the greater because they know little or nothing of the modern world and of international politics. Two centuries of solitary pastoral life have not only given them an aversion for commerce, for industrial pursuits, and for finance, but an absolute incapacity for such occupations, so that when gold was discovered in their country, they did not even attempt to work it, ${ }^{2}$ but were content to sell, usually for a price far below its value, the land where the gold-reefs lay, and move off with the proceeds to resume elsewhere their pastoral life. They have the virtues appropriate to a simple society. They are brave, good-natured,

1 The other common Boer name for an Englishman is "redneck," drawn from the fact that the back of an Englishman's neck is often burnt red by the sun. This does not happen to the Boer, who always wears a broad-brimmed hat.

2 Their laws at one time forbade the working of gold mines altogether, for they held with the Roman poet (aurum inrepertum et sic melius situm) that it does least harm when undiscovered. 
hospitable, faithful to one another, generally pure in their domestic life, seldom touched by avarice or ambition. But the corruption of their Legislature shows that it is rather to the absence of temptation than to any superior strength of moral principle that these merits have been due. For politics they have little taste or gift. Politics can flourish only where people are massed together, and the Boer is a solitary being who meets his fellows solely for the purposes of religion or some festive gathering. Yet ignorant and slow-witted as they are, inborn ability and resolution are not wanting. They have indeed a double measure of wariness and wiliness in their intercourse with strangers, because their habitual suspicion makes them seek in craft the defence for their ignorance of affairs ; while their native doggedness is confirmed by their belief in the continued guidance and protection of that Providence whose hand led them through the wilderness and gave them the victory over all their enemies.

This was the people into whose territory there came, after I884, a sudden swarm of gold-seekers. The Uitlanders, as these strangers are called (the word is not really Dutch, one is told, but an adaptation from the German), who by I 890 had come to equal and soon thereafter exceeded the whole number of the Boers, belonged to many stocks. The natives of England, the Cape, and Natal were the most numerous, but there were also many English-speaking men from other regions, including Australians and Americans, as well as a smaller 
number of Germans and Scandinavians, some Russians (mostly Jews) and a few Italians and Frenchmen. Unlike as these newcomers were to one another, they were all still more unlike the rude hunting and pastoral people among whom they came. They were miners, traders, financiers, engineers, keen, nimble-minded men, all more or less skilled in their respective crafts, all bent on gain, and most of them with that sense of irresponsibility and fondness for temporary pleasure which a chanceful and uncertain life, far from home, and relieved from the fear of public opinion, tends to produce. Except some of the men from Cape Colony, they could not speak the Boer Taal, and had no means of communication, any more than they had social or moral affinities, with the folk of the land. There were therefore no beginnings of any assimilation between them and the latter. They did not affect the Boers, except with a sense of repulsion, and still less did the Boers affect them. Moreover, there were few occasions for social intercourse. The Uitlanders settled only along the Witwatersrand, and were aggregated chiefly in Johannesburg. The Boers who had lived on the Rand, except a few who came daily into the towns with their waggons to sell milk and vegetables, retired from it. It was only in Pretoria and in a few of the villages that there was any direct social contact between the two elements.

Although less than half of the immigrants came from England, probably five-sixths spoke English 
and felt themselves drawn together not only by language, but by community of ideas and habits. The Australians, the Americans, and the men from Cape Colony and Natal considered themselves for all practical-I do not say for all political-purposes to be English, and English became the general spoken tongue not only of Johannesburg, but of the mining districts generally. Hearing nothing but English spoken, seeing nothing all round them that was not far more English than Dutch, though with a halfcolonial, half-American tinge, it was natural that the bulk of the Uitlanders should deem themselves to be in a country which had become virtually English, and should see something unreasonable or even grotesque in the control of a small body of persons whom they deemed in every way their inferiors. However, before I describe their sentiments and their schemes, some account must be given of the government under which they lived.

As was explained in a previous chapter (Chapter XII.) the South African Republic was formed by the union, between 1858 and 1862 , of several small and theretofore practically independent republican communities. Its constitution was set forth in a document called the Grondwet, or "Fundamental Law,"1

1 I have elsewhere analysed (in the Forum for April, 1896) this constitution, and discussed the question whether it is to be regarded as a true Rigid constitution, like that of the United States, of the Swiss Confederation, and of the Orange Free State, or as a Flexible constitution, alterable by the ordinary legislative machinery. 
enacted in $185^{8}$ and partly based on a prior draft of I 855. It is a very crude, and indeed rude, instrument, occasionally obscure, and containing much matter not fit for a constitution. It breathes, however, a thoroughly free spirit, save as regards Kafirs and Roman Catholics, recognising the people as the source of power, laying down the old distinction between the three departments of government,legislative, executive, and judicial,-and guaranteeing some of the primordial rights of the citizen. By it the Government was vested in a President, head of the executive, and elected for five years, an Executive Council of five members (three elected and two ex officio), and a Legislature called the Volksraad, elected by the citizens on a very extended suffrage, and declared to be the supreme power in the State. The Volksraad consists of one chamber, in which there are at present twenty-four members. The President has the right of speaking, though not of voting, in it, but has no veto on its action. Though there are few constitutions anywhere which give such unlimited power to the Legislature, the course of events-oft-recurring troubles of all sorts, native wars, internal dissensions, financial pressure, questions with the British Government-have made the President practically more important than the Legislature, and, in fact, the main force in the Republic. The Executive Council has exerted little power and commanded little deference, while the Volksraad has usually been guided by the President and has never taken the direction of affairs out of his hands. Both

L L 
legislation and administration have been carried on in a rough-and-ready fashion, sometimes in violation of the strict letter of the law. In particular, the provision of the Grondwet, that no statute should be enacted without being submitted for a period of three months to the people, has been practically ignored by the enactment as laws of a large number of resolutions on matters not really urgent, although the Grondwet permits this to be done only in cases which do not admit of delay.

In $188 \mathrm{I}$, when the Republic recovered its independence, there were neither roads, railways, nor telegraphs in the country. Its towns were rough hamlets planted round a little church. Its people had only the bare necessaries of life. The taxes produced scarcely any revenue. The treasury was empty, and the Government continued to be hardpressed for money and unable to construct public works or otherwise improve the country till I 885 , when the discovery of gold on the Witwatersrand began to turn a stream of gold into its coffers. Riches brought new difficulties and new temptations. Immigrants rushed in,-capitalists, miners, and traders. As the produce of the gold-field increased, it became plain that they would come in everincreasing numbers. The old Boers took alarm. The rush could hardly have been stopped, and to stop it would have involved a check in the expansion of the revenue. It was accordingly determined to maintain the political status quo by excluding these newcomers from political rights. The Grondwet 
declares (Article VI.) that "the territory is open for every foreigner who obeys the laws of the Republic," and as late as I88I an immigrant could acquire the electoral franchise after a residence of two years. In 1882 , however, this period was raised to five years, and in 1887 to fifteen. In I890, by which time the unenfranchised strangers had begun to agitate for the right to be represented, a nominal concession was made by the creation of a new chamber, called the Second Volksraad, for membership in which a newcomer might be eligible after taking an oath of allegiance followed by four years' residence, the right to vote at elections to this chamber being attainable after the oath and two years' residence. This Second Raad, however, is limited to the consideration of certain specified subjects, not including taxation, and its acts can be overruled by the First Volksraad, while its assent is not required to the acts of that body. It has therefore turned out little better than a sham, having, in fact, been created only as a tub to throw to the Uitlander whale. The effect of the legislation of I 890 and subsequent years down to I 894 (legislation too intricate and confused to be set forth in detail here) has been to debar any immigrant from acquiring the right to vote for the First Volksraad until he has passed the age of forty and resided for at least twelve years in the country after taking the oath and being placed on the local government lists, lists on which the local authorities are said to be nowise careful to place him. Nor does birth in the 
CHAP.

Republic confer citizenship, unless the father has taken the oath of allegiance. President Kruger, who has held office since I88I, was chiefly instrumental in passing these laws, for his force of character, long experience of affairs, and services in the crisis of I877-8I gave him immense power over the Raad, in which he constantly spoke, threatening the members with the loss of national independence unless they took steps to stem the rising tide of foreign influence. As a patriot, he feared the English; as a Boer Puritan of the old stubborn stock, he hated all foreigners and foreign ways, seeing in them the ruin of the ancient customs of his people. He carried this antagonism so far that, being unable to find among his citizens men sufficiently educated to deal with the growing mass of administrative work which the increase of wealth, industry, and commerce brought, he refused to appoint Dutch-speaking men from the Cape or Natal, because they were natives of British colonies, and recruited his civil service from Holland. The Hollanders he imported were far more strange to the country than Cape Dutchmen would have been, and the Boers did not, and do not now, take kindly to them. But they were, by the necessity of their position, anti-English, and that was enough.

Meanwhile the old Boer virtues were giving way under new temptations. The Volksraad (as is believed all over South Africa) became corrupt, though of course there have always been pure and upright men among its members. The civil service was not 
above suspicion. Rich men and powerful corporations surrounded those who had concessions to give or the means of influencing legislation, whether directly or indirectly. The very inexperience of the Boer ranchman who came up as a member of the Volksraad made him an easy prey. All sorts of abuses sprang up, while the primary duties of a Government were very imperfectly performed. Hardly any administration was needed while the Transvaal had a population of wandering stock-farmers. But when one hundred thousand white immigrants were congregated along the Witwatersrand, and were employing some fifty thousand native workpeople, an efficient police, an abundant water-supply, good sanitary regulations, and laws to keep liquor from the natives became urgently needed; and none of these things was provided, although taxation continued to rise and the treasury was overflowing. Accordingly, the discontent of the Uitlanders increased. It was no longer a mere question of obtaining political rights for their own sake; it was also a question of winning political power in order to reform the administration, and so secure those practical benefits which the President and the Volksraad and the Hollander officials were either unable or unwilling to give. In I 892 an association, called the National Union, was formed by a number of Uitlanders, "to obtain, by all constitutional means, equal rights for all citizens of the Republic, and the redress of all grievances." Although nearly all those who formed it were natives either of England 
or of the British colonies, it did not seek to bring the country under British control, but included among its aims "the maintenance of the independence of the Republic." Nevertheless, it incurred the hostility of the President and his friends, and its petitions were unceremoniously repulsed. This tended to accentuate the anti-Boer feeling of the Uitlanders, so that when Sir H. Loch, the High Commissioner, came up from the Cape in 1894 to negotiate regarding Swaziland and other pending questions, he was made the object of a vehement demonstration at Pretoria. The English took the horses out of his carriage and drew it through the streets, waving the British flag even over the head of President Kruger himself, and shouting "Reform! Reform!" This incident redoubled Mr. Kruger's apprehensions, but did not shake his purpose. It suggested new plans to the Uitlanders, who had (shortly before) been further incensed by the demand of the Government that they should, although debarred from the suffrage, serve in a military commando sent against the Kafir chief Malaboch. Despairing of constitutional agitation, they began to provide themselves with arms and to talk of a general rising. Another cause, which I have not yet mentioned, had recently sharpened their eagerness for reforms. About 1892 the theory was propounded that the gold-bearing reefs might be worked not only near the surface, but also at much greater depths, and that, owing to the diminution of the angle of the dip as the beds descend into the 
earth, a much greater mass of gold-bearing rock might be reached than had been formerly deemed possible. This view, soon confirmed by experimental borings, promised a far longer life to the mines than had been previously expected. Those who had come to the Rand thinking they might probably leave it after a few years now conceived the idea of permanent residence, while the directors of the great mining companies, perceiving how much their industry might be developed, smarted more than ever under the maladministration and exactions from which the industry suffered.

These were the events and these the causes that had brought about the state of things which a visitor saw at Pretoria and Johannesburg in November, 1895. Revolution was already in the air, but few could guess what form it would take. The situation was a complicated one, because each of the two main sections of the population, Boers and Uitlanders, was itself subdivided into minor groups. The Uitlanders were of many nationalities; but those who spoke English were so much the most numerous that I shall speak of them only, dismissing the remainder with the remark that while many of them sympathised with the Reform movement, few of them gave it active support, while most of the Germans, moved by anti-British feeling, favoured President Kruger's Government.

The English section, including Cape and Natal men, Australians and Americans, consisted of three sets of persons: the middle classes, the capitalist 
CHAP.

mine-owners, and the working men. The middleclass people, traders, professional men, engineers, and the like, either belonged to or were in sympathy with the National Union. It was they who had formed it. They had recently presented to the Volksraad a petition, signed by thirty-eight thousand non-enfranchised residents, asking for reforms, and this petition had been scornfully rejected, one member saying, with no disapproval from his colleagues, that if the strangers wanted to get what they called their rights they would have to fight for them. Their agitation had been conducted publicly and on constitutional lines, without threats of force. It was becoming plain, however, in 1895 , that some at least of the leaders were now prepared to use force and would take arms whenever a prospect of success appeared. But under what flag would they fight? Would they adhere to their original idea, and maintain an independent South African republic when they had ejected the dominant oligarchy and secured political power for all residents? Or would they hoist the Union Jack and carry the country back under the British crown? No one could speak positively, but most thought that the former course would be taken. The Americans would be for it. Most of the Cape people who came of Dutch stock would be for it. Even among the pure English, some talked bitterly of Majuba Hill, and declared they would not fight to give the country back to Britain which had abandoned it in $188 \mathrm{I}$. 
The motives of these Reformers were simple and patent. Those of them who had been born or lived long in Africa thought it an intolerable wrong that, whereas everywhere else in South Africa they could acquire the suffrage and the means of influencing the Government after two or three years' residence, they were in the Transvaal condemned to a long disability, and denied all voice in applying the taxes which they paid. Thinking of South Africa as practically one country, they complained that here, and here only, were they treated as aliens and inferiors. Both they and and all the other Uitlanders had substantial grievances to redress. Food was inordinately dear, because a high tariff had been imposed on imports. Water-supply, police, sanitation, were all neglected. Not only was Dutch the official language, but in the public schools Dutch was the only medium of instruction; and English children were compelled to learn arithmetic, geography, and history out of Dutch text-books. It was these abuses, rather than any wish to bring the Transvaal under the British flag, or even to establish a South African Confederation, that disposed them to revolt against a Government which they despised.

The mine-owning capitalists were a very small class, but powerful by their wealth, their intelligence, and their influence over those whom they employed. They had held aloof from the agitation which began in I892, because they did not themselves care for the franchise, not meaning to spend their lives in the Transvaal, and because they knew that political 
disturbances would interfere with the mining industry. The leading man, and certainly one of the ablest men among them, ${ }^{1}$ foresaw trouble as far back as June, I894, when he wrote that the unrest of the country came "from the open hostility of the Government to the Uitlanders, and its hostility to all principles of sound Government; the end will be revolution"; and a few weeks later wrote again: "The mining companies ought to have arms. The courage of the Boers is exaggerated. If they knew there were in Johannesburg three thousand wellarmed men, they would not talk so loud of destroying the town." Nevertheless, these capitalists, like capitalists all over the world, disliked force, and long refused to throw themselves into the movement. They raised a fund for the purpose of trying " to get a better Volksraad "- whether by influencing members or by supplying funds for election expenses has never been made clear. However, these efforts failed, and they became at last convinced that the loss of their industry from misgovernment was, and would continue, greater than any loss which temporary disturbances might involve. The vista of deep-level mining, which had now opened itself before them, made their grievances seem heavier. Before they entered on a new series of enterprises, which would at first be costly, they wished to relieve mining from the intolerable burdens of a dynamite monopoly, foolishly or corruptly granted to a firm

1 Copies of the letters written by Mr. Lionel Phillips were seized after the rising and published by the Boer Government. 
which charged an extortionate price for this necessity; of a high tariff both on food-stuffs, involving large expenses in feeding the workpeople, and on mine machinery; of extravagantly heavy railway rates for coal ; and of a system which, by making it easy for the Kafir workers to get drunk, reduced the available amount of native labour by one-third, and increased the number of accidents in the mines. These burdens made the difference of one or two or three per cent. on the dividend in the best mines, threatened the prospect of any dividend on the second best, and made it useless to persevere with the working of a third class, where the ore was of a still lower grade. Such were the considerations which at last determined several of the leading mine-owners to throw in their lot with the Reform party; and the fusion of the two streams gave a new force to the movement. This fusion took place in the middle of I 895, and had become known to many, though not to all, of the Johannesburgers in November of that year. It inspired them with fresh hopes, and made them think that the day of action was near. The object of these capitalists was to obtain better government, not the extinction of the Republic, or its addition to the territories of Britain. This, however, was not the main object of Mr. Rhodes (then prime minister of Cape Colony and managing director of the British South Africa Company) with whom they were (though the fact was known only to a very few of the leaders) by this time in com- 
munication. Although he was largely interested in some of the mines, his aim was, as even his opponents have now admitted, not a pecuniary one. It was (as is generally believed) to prevent the Transvaal from passing under anti-British influences, and to secure that it should ultimately become incorporated in a confederation of the several States and colonies of South Africa under the British crown. There were probably others among the leaders who shared this purpose ; but some did not, and here was a question which would seem to have divided the chiefs as it divided the rank and file. A rising there was to be. But under what flag? This vital point was left unsettled, and at the last moment it caused a fatal delay.

The third class of Uitlanders consisted of the white workmen. It was the most numerous class, and its action would evidently be decisive. When the visitor who heard the situation discussed-for there was no secrecy observed-asked about the attitude of the working men, he received no very definite answer. The general belief was that they would respond to a call to arms: some from patriotism, because most of them were Englishmen and Australians; some because they meant to make the Transvaal their home, and had an interest in good government; some from sympathy with their employers; some from the love of a fight, because they were men of mettle. One or two of the Reform leaders were able speakers, and meant to rouse them by eloquence when the proper moment arrived. 
The result showed that a majority - that is, of the English-speaking workmen-were willing to fight. But when the day of battle seemed to be at hand, many, including most of the Cornish miners, proved to be indifferent, and departed by train amid the jeers of their comrades.

These three sections of Uitlanders constituted a numerical majority not merely of the dwellers on the Rand, but of the whole white population of the country. ${ }^{1}$ There are about 65,000 Boers, all told, and about 24,000 male citizens over the age of sixteen. The English-speaking Uitlanders numbered nearly 100,000, of whom fully one-half were adult males. Seven-eighths of these were gathered on the Rand. Had they been armed and drilled and unanimous, they would have been irresistible. But they were not unanimous, and were, moreover, not only unarmed but also unorganised, being a crowd of persons suddenly gathered from the four winds of heaven.

Over against the Uitlanders stood the native Boer population, among whom we must distinguish two classes. The majority, consisting of the old "true blues" who hated the English and clung to their national ways, supported the Government in its stubborn refusal to grant reforms. The President in particular had repeatedly declared himself against any concession, insisting that no concessions

1 There were some 700,000 Kafirs in the Transvaal, but no one reckoned them as possible factors in a contest, any more than sheep or oxen. 
would satisfy the disaffected. He looked upon the whole movement as a scheme to destroy the independence of the country and hand it over to England. Exercising by his constant harangues in the Volksraad, what has been called a "dictatorship of persuasion," he warned the people that their customs, their freedom, their religion, were at stake, and could be saved only by keeping the newcomers out of power. He was confirmed in this policy of resistance by the advice of his Hollander officials, and especially of the State Secretary, an able and resolute man.

But the President, though powerful, was not omnipotent. There existed a considerable party opposed to him, which had nearly overthrown him at the last preceding. presidential election. There was in the Volksraad a liberal minority, which advocated reforms. There were among the country Boers a number of moderate men who disliked the Hollander influence and the maladministration of the Government, and one was told (though with what truth I could not ascertain) that the trekking which went on out of the Transvaal into Mashonaland and to the far north-west was partly due to this discontent. There was also much opposition among the legal profession, Dutch as well as English, for attacks had been made upon the independence of the judiciary, and the reckless conduct of legislation gave displeasure. So far back as 1894 the Chief Justice, a man greatly respected for his abilities and his services to the State, had delivered a public address warning the people against the dangers which 
threatened them from neglect of the provisions of the constitution. Whether this party of opposition among the enfranchised citizens would have aided the Reform movement was doubtful. They would certainly not have done so had the British flag been raised. But if the movement had sought only the destruction of Hollander influence and the redress of grievances, they would at any rate have refused to join in resisting it.

"Why," it may be asked- "why, under these circumstances, with so many open enemies and so many wavering supporters, did not President Kruger bow to the storm and avert revolt by reasonable concessions?" He had not a friend in the world except Germany, which had gone out of her way to offer him sympathy. But Germany was distant, and he had no seaport. The people of the Orange Free State had been ready to help the Transvaal in I88I, and from among the Boers of Cape Colony there might in the crisis of that year have come substantial succour. But both the Free State and the Cape Boers had been alienated by the unfriendly attitude of the President in commercial matters and by his refusal to employ Cape Dutchmen in the Transvaal service. The annoyance of these kindred communities had been very recently accentuated by a dispute about the drifts (i.e., fords where waggons cross) on the Orange River. It was therefore improbable that any help could be obtained from outside against a purely internal movement, which aimed solely at reform, and did not threaten the life of the Republic. 
The answer to the question just put is to be found not so much in the material interests as in the sentiments of the old Boer party. They extended their hatred of the English to the English-speaking Uitlanders generally, and saw in the whole movement nothing but an English plot. If the President had cared to distinguish, he might have perceived that the capitalists cared, not for the franchise, but for the success of their mines; and he might, by abolishing the wasteful concessions,-which did not even enrich the State, but only the objects of its illdirected bounty, - by reducing the tariff, and by keeping drink from the blacks, have disarmed the hostility of the mine owners, and have had only the National Union to deal with. Even the National Union would have lost most of its support if he had reformed the administration and allowed English to be used in the schools. He might have taken a hint from the Romans, who, when they admitted a large body of new citizens, managed to restrict their voting power, and might, in granting the suffrage to those who had resided for a certain period on the Rand, have kept the representation of the Rand district so small that it could not turn the balance against the old Boer party in the Volksraad. Had he gone further, and extended the franchise to all immigrants after, say, five years' residence, he might not only have disarmed opposition, but have made the South African Republic a powerful State, no considerable section of whose inhabitants would thereafter have thought of putting themselves under 
the British crown. To have gone this length would no doubt have been to take the risk that a republic of Boers might become before long a republic of Englishmen, with an English President; and from this he naturally recoiled, not merely out of personal ambition, but out of honest national feeling. But short of this, he might, by dividing his enemies, have averted a grave peril, from which he was in the end delivered, not by his own strength, but by the mistakes of his antagonists. However, he kept the ship steadily on her course. He had grown accustomed to the complaints of the agitators, and thought they would not go beyond agitation. When pressed to take some repressive measure, he answered that you must wait for the tortoise to put its head out before you hit it, and he appeared to think it would keep its head in. $\mathrm{He}$ is one of the most interesting figures of our time, this old President, shrewd, cool, dogged, wary, courageous; typifying the qualities of his people, and strong because he is in sympathy with them; adding to his trust in Providence no small measure of worldly craft; uneducated, but able to foil the statesmen of Europe at their own weapons, and perhaps all the more capable because his training has been wholly that of an eventful life and not of books.

This was how things stood in the Transvaal in November, 1895 . People have talked of a conspiracy, but never before was there, except on the stage, ${ }^{1}$

1 This operatic element appeared in the rising itself, when a fire-escape, skilfully disguised to resemble a Maxim gun, was 
CHAP.

so open a conspiracy. . Two-thirds of the action - there was another third, which has only subsequently become known-went on before the public. The visitor had hardly installed himself in an hotel at Pretoria before people began to tell him that an insurrection was imminent, that arms were being imported, that Maxim guns were hidden, and would be shown to him if he cared to see them, an invitation which he did not feel called on to accept. In Johannesburg little else was talked of, not in dark corners, but at the club where everybody lunches, and between the acts at the play. There was something humorous in hearing the English who dominate in so many other places, talking of themselves as a downtrodden nationality, and the Boers as their oppressors, declaring that misgovernment could not be endured for ever, and that those who would be free themselves must strike the blow. The effect was increased by the delightful unconsciousness of the English that similar language is used in Ireland to denounce Saxon tyranny. The knowledge that an insurrection was impending was not confined to the Transvaal. All over South Africa one heard the same story; all over South Africa men waited for news from Johannesburg, though few expected the explosion to come so soon. One thing alone was not even guessed at. In November it did not seem to have crossed any one's mind that the British South Africa Company would moved backward and forward across the stage at Johannesburg for the purpose of frightening the Boers at a distance. 
have any hand in the matter. Had it been supposed that it was concerned, much of the sympathy which the movement received would have vanished.

As I am not writing a history of the revolution, but merely describing the Johannesburg aspects of its initial stage, I need not attempt the task-for which, indeed, no sufficient materials as yet existof explaining by what steps and on what terms the Company's managing director and its administrator and its police came into the plan. But it seems clear that the Johannesburg leaders did not begin to count upon help from the Company's force before the middle of 1895 at earliest, and that they did not regard that force as anything more than an ultimate resource in case of extreme need. Knowing that the great body of the Uitlanders, on whose support they counted, would be unorganised and leaderless, they desired, as the moment for action approached, to have a military nucleus round which their raw levies might gather, in case the Boers seemed likely to press them hard. But this was an afterthought. When the movement began, it was a purely Johannesburg movement, and it was intended to bear that character to the end, and to avoid all appearance of being an English irruption. ${ }^{1}$

1 It is hardly necessary to point out the absurdity of the statement, frequently made within the last few months, that the Company intended to seize the Transvaal for itself. The Company could no more have taken the Transvaal than it could have taken Natal. It was for self-government that the insurgentUitlanders were to rise, and they would have objected to be governed by the Company at least as much as they objected to 
To the visitor who saw and heard what I have been describing-and no Englishman could pass through without seeing and hearing it-two questions naturally presented themselves. One related to the merits of the case. This was a question which only a visitor considered, for the inhabitants were drawn by race or interest to one side or the other. It raised a point often debated by moralists : What are the circumstances which justify insurrection? Some cases are too clear for argument. Obviously any subject of a bloodthirsty tyrant ruling without or against law is justified in taking up arms. No one doubts that the Christian subjects of the Sultan ought to rebel if they had a prospect of success; and those who try to make them rebel are blamed only because the prospect of success is wanting. On the other hand, it is clear that subjects of a constitutional Government, conducted in accordance with law, do wrong, and must be punished if they take arms, even when they have grievances to redress. Here, however, was a case which seemed to lie between the extreme instances. The Uitlanders, it need hardly be governed by the Boers. Such individual members of the Company as held Rand mining shares would have profited by the better administration of the country under a reformed Government, but they would have profited in exactly the same way as shareholders in Paris or Amsterdam. This point, obvious enough to any one who knows South Africa, is clearly put by M. Mermeix, in his interesting little book, La Révolution de Johannesburg. Other fanciful hypotheses have been put forward, which it seems needless to notice. 
be said, did not concern themselves with nice distinctions. In the interior of South Africa Governments and Constitutions were still in a rudimentary stage; nor had the habit of obeying them been fully formed. So many non-legal things had been done in a high-handed way, and so many raids into native territories had been made by the Boers themselves, that the sort of respect for legality which Europeans feel was still imperfectly developed in all sections of the population. Those of the Reformers, however, who sought to justify their plans, argued that the Boer Government was an oligarchy which overtaxed its subjects, and yet refused them those benefits which a civilised Government is bound to give. It was the Government of a small and ignorant minority, and, since they believed it to be corrupt as well as incompetent, it inspired no respect. Peaceful agitation had proved useless. Did not the sacred principle of no taxation without representation, which had been held to justify the American Revolution, justify those who had been patient so long in trying to remove their grievances by force, of course with as little effusion of blood as possible?

On the other hand, there was much to be said for the Boers, not only from the legal, but from the sentimental, side of the case. They had fled out of Cape Colony sixty years before, had suffered many perils and triumphed over many foes, had recovered their independence by their own courage when Britain had deprived them of it, had founded a 
commonwealth upon their own lines, and could now keep it as their own only by the exclusion of those aliens in blood, speech, and manners who had recently come among them. They had not desired these strangers, nor had the strangers come for anything but gold. True, they had opened the land to them, they had permitted them to buy the gold-reefs, they had filled their coffers with the taxes which the miners paid. But the strangers came with notice that it was a Boer State they were entering, and most of them had come, not to stay, and to identify themselves with the old citizens, but to depart after amassing gain. Were these immigrants of yesterday to be suffered to overturn the old Boer State, and build up on its ruins a new one under which the Boer would soon find his cherished customs gone and himself in turn a stranger? Had not the English many other lands to rule, without appropriating this one also? Put the grievances of which the Uitlanders complained at their highest, and they did not amount to wrongs such as had in other countries furnished the usual pretext for insurrection. Life, religion, property, personal freedom, were not at stake. The worst any one suffered was to be overtaxed and to want some of those advantages which the old citizens had never possessed and did not care to have. These were hardships, but were they hardships such as could justify a recourse to arms?

The other question which an observer asked himself was whether an insurrection would succeed. 
Taking a cooler view of the position than it was easy for a resident to take, he felt some doubt on this point, and it occurred to him to wonder whether, if the Government was really so corrupt as the Uitlanders described it, the latter might not attain their object more cheaply, as well as peaceably, by using those arguments which were said to prevail with many members of the Volksraad. Supposing this to be impossible,-and it may well have been found impossible, for men not scrupulous in lesser matters may yet refuse to tamper with what they hold vital,-were the forces at the disposal of the Reform leaders sufficient to overthrow the Government? It had only two or three hundred regular troops, artillerymen stationed at Pretoria, and said to be not very efficient. But the militia included all Boers over sixteen ; and the Boer, though not disciplined in the European way, was accustomed to shoot, inured to hardships by his rough life, ready to fight to the death for his independence. This militia, consisting of sixteen thousand men or more, would have been, when all collected, more than a match in the field for any force the Uitlanders were prepared to arm. And in point of fact, when the rising took place, the latter had only some three thousand rifles ready, while few of their supporters knew anything of fighting. As the Reform leaders were aware that they would be outmatched if the Government had time to gather its troops, it has been subsequently hinted that they meant to carry Pretoria by a coup de main, capturing the President, and forthwith, 
CHAP.

before the Boer militia could assemble, to issue a call for a general popular vote or plebiscite of all the inhabitants, Boers and Uitlanders, which should determine the future form of government. Others have thought that the Reformers would not have taken the offensive, but have entrenched themselves in Johannesburg, and have held out there, appealing meanwhile to the High Commissioner, as representative of the Paramount Power, to come up, interpose his mediation, and arrange for the peaceable taking of such a general popular vote as I have mentioned. To do this it might not have been necessary to defend the town for more than a week or ten days, before which time the general sympathy which they expected from the rest of South Africa would have made itself felt. Besides, there were in the background (though this was of course unknown to the visitor and to all but a few among the leaders) the British South Africa Company's police force at Pitsani, who were pledged to come if summoned, and whose presence would have enabled them to resist a Boer assault on the town.

As everybody knows, the question of strength was never tested. The rising was to have been ushered in by a public meeting at the end of December. This meeting was postponed till the 6th of January, but the Company's police force, instead of waiting to be summoned, started for Johannesburg at the time originally fixed. Their sudden entrance, taking the Reform leaders by surprise and finding them unprepared, forced the 
movement to go off at half-cock, and gave to it an aspect quite different from that which it had hitherto borne. That which had been a local agitation now appeared in the light of an English invasion, roused all the Boers, of whatever party, to defend their country, and drew from the High Commissioner an emphatic disclaimer and condemnation of the expedition, which the home Government repeated. The rising at Johannesburg, which the entrance of the police had precipitated, ended more quickly than it had begun, as soon as the surrender of the Company's force had become known, for the representatives of the High Commissioner besought the Uitlanders to lay down their arms and save the lives of the leaders of that force. ${ }^{1}$ This they did, and, after what had happened. there was really nothing else to be done.

The most obvious moral of the failure is the old one that revolutions are not so easy to carry out as they look when one plans them beforehand. Of all the insurrections and conspiracies recorded in history, probably not five per cent. have succeeded. The reason is that when a number of private persons not accustomed to joint action have to act

1 Much controversy has arisen as to the promise which the Boer commandant made, when the police force surrendered, that the lives of its leaders should be spared. Whatever might have happened immediately after the surrender, they would in any case not have been put to death in cold blood at Pretoria, for that would have been a blunder, which a man so astute and so far from cruel as the President would not have committed. 
CHAP.

secretly together, unable to communicate freely with one another, and still less able to appeal beforehand to those on whose eventual support they rely, the chances of disagreement, of misunderstanding, of failure to take some vital step at exactly the right moment, are innumerable; while the Government in power has the advantage of united counsels, and can issue orders to officers who are habituated to prompt obedience. ${ }^{1}$ In this instance, the plan was being conducted by three groups of persons in three places distant from one another,-Johannesburg, Pitsani, and Cape Town,- -so that the chances of miscarriage were immensely increased. Had there been one directing mind and will planted at Johannesburg, the proper centre for direction, the movement might have proved successful.

Another reflection will have occurred to the reader, as it occurred to the visitor who saw the storm brewing in November, I895: Why could not the Reformers have waited a little longer? Time was on their side. The Uitlanders were rapidly growing by the constant stream of immigrants. In a few years more they would have so enormously outnumbered the native Boers that not only would their material strength have been formidable, but their claim to the franchise would have become practically irresistible. Moreover, President Kruger was an old man, no longer in strong health. When age and

1 When a conspiracy succeeds, the chief conspirator is usually some one already wielding some civil or military power, as Louis Napoleon did when he overcame the French Assembly in 185 I. 
infirmity compelled his retirement, neither of the persons deemed most likely to succeed would have thrown obstacles in the way of reform, nor would any successor have been able to oppose a resistance as strong as Mr. Kruger's had proved. These considerations were so obvious that one asks why, with the game in their hands at the end of a few years, the various groups concerned did not wait quietly till the ripe fruit fell into their mouths. Different causes have been assigned for their action. It is said that they believed that the Transvaal Government was on the eve of entering into secret relations, in violation of the Convention of I884, with a European Power, and that this determined them to strike before any such new complication arose. Others hint that some of those concerned believed that a revolution must in any case soon break out in the Transvaal, that a revolution would turn the country into an independent English republic, that such a republic would spread republican feelings among the British colonies, and lead before long to their separation from the mother country. To prevent this, they were resolved to take control of the movement and steer it away from those rocks. Without denying that these or other still more conjectural motives which one hears assigned may have influenced some of the more long-sighted leaders, and the Transvaal, with its vast wealth and growing population, was no doubt becoming the centre of gravity in South African politics,-I conceive that a more obvious cause of haste may be found in the 
impatience of those Uitlander residents who were daily vexed by grievances for which they could get no redress, and in the annoyance of the capitalists, who saw their mining interests languishing and the work of development retarded. When people have long talked over their wrongs and long planned schemes for throwing off a detested yoke, they yield at last to their own impatience, feeling half ashamed that so much talk should not have been followed by action.

Whatever were the motives at work, whatever the ultimate aims of the leaders, few things could have been more deplorable than what in fact occurred. Since the annexation of the Transvaal in I 877 nothing has done so much to rekindle racial hostility in South Africa ; nothing has so much retarded and still impedes the settlement of questions which were already sufficiently difficult.

I have described in this chapter only such part of the circumstances which led up to the rising as I actually saw, and have, for reasons already stated, confined myself to a narrative of the main facts, and a statement of the theories put forward, abstaining from comments on the conduct of individuals. The expedition of the British South Africa Company's police took place after I left the country. Of it and of what led to it oral accounts have been given by some of the principal actors, as well as by many independent pens, while the visible phenomena of the Johannesburg movement have been less described and are certainly less under- 
stood. I have dwelt on them the more fully not only because they are a curious episode in history which will not soon lose its interest, but also because the political and industrial situation on the Witwatersrand is still substantially what it was in 1895. Some few reforms have been given, some others promised. But the mine owners have not ceased to complain, and the Uitlanders are excluded from the suffrage as rigorously as ever. The Transvaal difficulty remains, and still disturbs the tranquillity of South Africa. The problem is not a simple one, and little or no progress has been made toward its solution. 


\section{CHAPTER XXVI}

THE ECONOMIC FUTURE OF SOUTH AFRICA

Though I do not attempt to present in this book an account of the agricultural and mineral resources of South Africa, some words must be said regarding its economic prospects - that is to say, regarding the natural sources of wealth which it possesses, their probable development, and the extent to which that development will increase the still scanty population. The political and social future of the country must so largely depend on its economic future that any one who desires to comprehend those political problems to the solution of which the people are moving must first consider what sort of a people, and how large a people, the material conditions which nature furnishes are likely to produce.

The chief charm of travel through a new country is the curiosity which the thought of its future inspires. In South Africa, a land singularly unlike any part of Europe or of North America, this curiosity is keenly felt by the visitor. When he begins to speculate on the future, his first question is, Will these wildernesses ever become peopled, as 
most of North America and a large part of Australia have now been peopled, and if so, what will be the character of the population? Will South Africa become one of the great producing or manufacturing countries of the world? Will it furnish a great market for European goods? Will it be populous enough and rich enough to grow into one of the powers of the southern hemisphere?

Let us begin by recalling the physical features of the country. Most of it is high and dry; all of it is hot. The parts which are high and dry are also healthy, and fit for the races of Europe to dwell in. But are they equally fit to support a dense population?

South Africa has three great natural sources of wealth : agricultural land, pasture-land, and minerals. The forests are too scanty to be worth regarding; they are not, and probably never will be, sufficient to supply its own needs. Fisheries also are insignificant, and not likely ever to constitute an industry, so we may confine ourselves to the three first named.

Of these three agriculture is now, and has hitherto been, by far the least important. Out of an area of two hundred and twenty-one thousand square miles in Cape Colony alone, probably not more than one onethousandth part is now under any kind of cultivation, whether by natives or by whites; and in the whole country, even if we exclude the German and Portuguese territories, the proportion must be much smaller. There are no figures available, so one can make only the roughest possible conjecture. As 
CHAP.

regards more than half of the country, this fact is explained by the dryness of the climate. Not only the Karroo region in the interior of Cape Colony, but also the vast region stretching north from the Karroo nearly as far as the west-coast territories of Portugal, is too arid for tillage. So are large parts of the Free State, of the Transvaal, and of Matabililand. Where there is a sufficient rainfall, as in many districts along the south and south-east coasts, much of the country is too hilly and rough for cultivation ; so that it would be well within the mark to say that of the whole area mentioned above far less than onetenth is suitable for raising any kind of crop without artificial aid. Much, no doubt, remains which might be tilled and is not tilled, especially in the country between the south-eastern edge of the great plateau and the sea; and that this land lies untouched is due partly to the presence of the Kafir tribes, who occupy more land than they cultivate, partly to the want or the dearness of labour, partly to the tendency, confirmed by long habit, of the whites to prefer stockfarming to tillage. The chief agricultural products are at present cereals, i.e., wheat, oats, maize, and Kafir corn (a kind of millet), fruit and sugar. The wheat and maize raised are not sufficient for the consumption of the inhabitants, so that these articles are largely imported, in spite of the duties levied on them. There is a considerable and an increasing export of fruit, which goes to Europe-chiefly to the English market-in January, February, and March, the midsummer and autumn of the southern hemi- 
sphere. Sugar is grown on the hot lands of Natal lying along the sea, and might, no doubt, be grown all the way north along the sea from there to the Zambesi. Rice would do well on the wet coast lands, but is scarcely at all raised. Tea has lately been planted on the hills in Natal, and would probably thrive also on the high lands of Mashonaland. There is plenty of land fit for cotton. The tobacco of the Transvaal is so pleasant for smoking in a pipe that one cannot but expect it to be in time much more largely and carefully grown than it is now. Those who have grown accustomed to it prefer it to any other. With the exception of the olive, which apparently does not succeed, and of the vine, which succeeds only in the small district round Cape Town that enjoys a true summer and winter, nearly all the staples of the warmer parts of the temperate zone and of subtropical regions can be grown.

The introduction of irrigation would enormously enlarge the area of tillage, for some of the regions now hopelessly arid, such as the Karroo, have a soil of surprising fertility, which produces luxuriant crops when water is led on to it. Millions of acres might be made to wave with corn were great tanks, like those of India, constructed to hold the rains of the wet season, for it is not so much the inadequacy of the rainfall as the fact that it is confined to three or four months that makes the country arid. Something might also be hoped from the digging of artesian wells dug like those which have lately been successfully bored in Algeria, and 
have proved so infinitely valuable to parts of Australia. Already about three hundred thousand acres are cultivated with the aid of irrigation in Cape Colony. At present, however, it has been deemed hardly worth while to execute large irrigation works or to bore wells. ${ }^{1}$ The price of cereals has sunk so low over all the world that South Africans find it cheaper to import them than to spend capital on breaking up waste lands ; and there is plenty of land already which might be cultivated without irrigation if there were settlers coming to cultivate it, or if Kafir labour was sufficiently effective to make it worth the while of enterprising men to undertake farming on a large scale. The same remarks apply generally to the other kinds of produce I have mentioned. As population grows, and the local demand for food increases, more land will be brought under the plough or the hoe. Some day, perhaps, when the great corn-exporting countries of to-day-North America, La Plata, central India, southern Russia-have become so populous as to have much less of their grain crops to spare for other countries, it will become profitable to irrigate the Karroo, on which the Kafir of the future will probably prove a more efficient labourer than he is now. But that day is distant, and until it arrives, agriculture will continue to play a very subordinate part in South African industry, and will employ a comparatively small white population.

1 It is still doubtful whether very large areas can be irrigated by means of artesian wells. 
Ever since the last years of the seventeenth century, when the settlers were beginning to spread out from the Cape Peninsula towards the then still unknown interior, the main occupation of the colonists, first of the Dutch and afterwards of both Dutch and English, has been the keeping of cattle and sheep. So it remains to-day. Nearly all the land that is not rough mountain or waterless desert, and much that to the inexperienced eye seems a waterless desert, is in the hands of stock farmers, whose ranges are often of enormous size, from six thousand acres upward. In 1893 there were in Cape Colony about 2,000,000 cattle, in Natal 725,000, in the Orange Free State 900,000, and in Bechuanaland the Bamangwato (Khama's tribe) alone had 800,000. Of these last only some 5,000 are said to have survived the murrain, which has (July, I897) begun to work havoc in the other three first-mentioned territories also. In 1896 there were in Cape Colony alone I 4,400,000 sheep and 5,000,000 Angora and other goats. The number of sheep might be largely increased were more effective measures against the diseases that affect them carried out. All the country, even the Kalahari Desert, which used to be thought hopelessly sterile, is now deemed fit to put some sort of live stock upon, though, of course, the more arid the soil, the greater the area required to feed one sheep. To the traveller who crosses its weary stretches in the train the Karroo seems a barren waste ; but it produces small succulent shrubs much relished by sheep, and every here and there a 
CHAP.

well or a stagnant pool may be found which supplies water enough to keep the creatures alive. Here six acres is the average allowed for one sheep. Tracts of rough ground, covered with patches of thick scrubby bushes, are turned to account as ostrich farms, whence large quantities of feathers are exported to Europe and America. In 1896 the number of ostriches in Cape Colony was returned as 225,000. The merino sheep, introduced seventy years ago, thrives in Cape Colony, and its wool has become one of the most valuable products of the country. In the Free State both it and the Angora goat do well, and the pasture lands of that territory support also great numbers of cattle and some horses. The Free State and Bechuanaland are deemed to be among the very best ranching grounds in all South Africa.

Although, as I have said, nearly all the country is more or less fit for live stock, it must be remembered that this does not imply either great pecuniary returns or a large population. In most districts, a comparatively wide area of ground is required to feed what would be deemed in western America a moderate herd or flock, because the pasture is thin, droughts are frequent, and locusts sometimes destroy a large part of the herbage. Thus the number of persons for whom the care of cattle or sheep in any given area provides occupation is a mere trifle compared to the number which would be needed to till the same area. Artesian wells might, no doubt, make certain regions better for pastoral purposes; 
but here, as in the case of agriculture, we find little prospect of any dense population, and, indeed, a probability that the white people will continue to be few relatively to the area of the country. On a large grazing farm the proportion of white men to black servants is usually a out three to twenty-five ; and though the proportion of whites is, of course, much larger in the small towns which supply the wants of the surrounding country, still any one can see with how few whites a ranching country may get along.

The third source of wealth lies in the minerals. It was the latest source to become known-indeed, till thirty years ago, nobody suspected it. Iron had been found in some places, copper in others; but neither had been largely worked, and the belief in the existence of the precious metals rested on nothing more than a Portuguese tradition. In 1867 the first diamond was picked up by a hunter out of a heap of shining pebbles near the banks of the Orange River, above its confluence with the Vaal. In $1869-70$ the stones began to be largely found near where the town of Kimberley now stands. This point has been henceforth the centre of the industry, though there are a few other mines elsewhere of smaller productive power. The value of the present annual output exceeds $£ 4,000,000$, but it is not likely to increase, being, in fact, now kept down in order not to depress the market by oversupply. Altogether about $£ 100,000,000$ worth of diamonds have been exported. The discovery of 
CHAP.

diamonds, as was observed in an earlier chapter, opened a new period in South African history, drawing crowds of immigrants, developing trade through the seaports as well as industry at the mining centres, and producing a group of enterprising men who, when the various diamondmining companies had been amalgamated, sought and found new ways of employing their capital. Fifteen years after the great diamond finds came the still greater gold finds at the Witwatersrand. The working of these mines has now become the greatest industry in the country, and Johannesburg is the centre toward which the import trade converges.

I need not repeat the description given in a previous chapter (Chapter XVIII) of the Rand mining district. The reader will remember that it differs from all the other gold fields of South Africa in one essential feature-that of the comparative certainty of its yield. Accordingly, in considering the future of South African gold, I will speak first of those other gold fields and then separately of the Rand district.

Gold has been found in many places south of the Zambesi. It occurs here and there in small quantities in Cape Colony, in somewhat larger quantities in Natal, Zululand, and Swaziland, in the eastern and north-eastern districts of the Transvaal, at Tati in northern Bechuanaland, and in many spots through Matabililand and Mashonaland. In all (or nearly all) these places it occurs in quartz reefs re- 
sembling those of North America and Australia. Some reefs, especially those of the northern region between the Limpopo and Zambesi, are promising, and great quantities of gold have in times long past been taken out of this region. As already explained (Chapter XVII), it seems probable, though not certain, that in many districts a mining industry will be developed which will give employment to thousands, perhaps many thousands, of natives, and to hundreds, perhaps many hundreds, of white engineers and foremen. Should this happen, markets will be created in these districts, land will be cultivated, railways will be made, and the local trades which a thriving population requires will spring up. But the life of these gold reefs will not be a long one. As the gold is found in quartz rock, and only to a small extent in gravel or other alluvial deposits, the mining requires capital, and will be carried on by companies. It will be carried on quickly, and so quickly with the aid of the enormously improved scientific appliances we now possess, as to exhaust at no distant period the mineral which the rocks contain. I have seen in Transylvania a gold mine which was worked in the days of the Romans, and is being worked still. But mining now is as different from the mining of the ancients or of the middle ages as a locomotive engine is from an ox-waggon, such are the resources which chemical and mechanical science place at our disposal. Accordingly, the payable parts of the quartz reefs will have been drained of their gold in a few years, or, at any rate, 
in a few decades, just as many of the silver lodes of Nevada have already been worked out and abandoned. There will then be no further cause for the existence of the mine-workers at those points, and the population will decline just as that of Nevada has declined. These South African districts will, however, be in one point far better off than Nevada : they possess land fit everywhere for ranching, and in many places for tillage also. Ranching will, therefore, support a certain, though not large, permanent population; while tillage, though the profitable market close by will have been largely reduced by the departure of the miners, will probably continue, because the land will have been furnished with farm-houses and fences, perhaps in places with irrigation works, and because the railways that will have been constructed will enable agricultural products to reach more distant markets, which by that time may possibly be less glutted with the cereals of North and South America. Accordingly, assuming that a fair proportion of the quartz reef gold fields turn out well, it may be predicted that population will increase in and round them during the next ten years, and that for some twenty years more this population will maintain itself, though of course not necessarily in the same spots, because, as the reefs first developed become exhausted, the miners will shift to new places. After these thirty or possibly forty years, that is to say, before the middle of next century, the country, having parted with whatever gold it con- 
tains, will have to fall back on its pasture and its arable land; but having become settled and developed, it may count on retaining a reasonable measure of prosperity.

This forecast may seem to be of a highly conjectural nature. Conjectural it must be, if only for this reason: that the value of nearly all of the quartz reefs referred to is still quite uncertain. But one cannot visit a new country without attempting to nake a forecast of some kind; and the experience of other countries goes to show that, while deposits of the precious metals are, under our present conditions, no more an abiding source of wealth than is a guano island, they may immensely accelerate the development of a country, giving it a start in the world, and providing it with advantages, such as railway communication, which could not otherwise be looked for. This they are now doing for Matabililand and Mashonaland, countries in which it would not at present be worth while to construct railroads but for the hopes attaching to the mines. This they may do for Zululand and Swaziland also, should the reefs in those districts prove profitable.

So much for the quartz reefs. As has been observed, the gold mines of the Witwatersrand differ in the much greater certainty of their yield and in the much greater quantity of auriferous rock which they have been ascertained to contain. It is probable that gold of the value of $£ 700,000,000$ remains to be extracted from them. Already a population of at least I50,000 white men has collected in what 
CHAP.

only twelve years ago was a barren wilderness; already nearly $£ \mathrm{I} 0,000,000$ of gold per annum is being extracted. It is practically certain that this production and population will go on increasing during the next few years, and that the mines will not be worked out before the middle of next century at earliest. For the next fifty or sixty years, therefore, the Rand district will be the economic and industrial centre of South Africa and the seat of the largest European community. What will it be after those sixty or perhaps seventy years, when the banket beds have been drained of their gold to a depth of 5,000 feet, the greatest at which mining seems to be practicable? It is possible that the other industries which are rising as ancillary to mining may for a while and to a reduced extent hold their ground. Probably, however, they will wither up and vanish. The land will remain, but the land of this highest part of the Transvaal, though fit for pasture, does not lend itself to tillage. The probabilities, therefore, are that the fate of Nevada will in time descend upon the Witwatersrand-that the houses that are now springing up will be suffered to fall to ruin, that the mouths of the shafts will in time be covered by thorny shrublets, and that soon after A.D. 2000 has been reached this busy hive of industry and noisy market-place of speculation will have again become the stony solitude which it was in I880. For all practical purposes, however, an event a hundred years away is too distant to be worth regarding. The world will in A.D. 2000 be so 
different from what it is now that the exhaustion of the Rand gold field may have a different bearing from any which we can now foresee. Johannesburgers themselves are not disquieted by thoughts of a future that is even half a century distant. The older sort will not live to see it, and the younger sort expect to have made their fortunes long before it arrives. Still it must be remembered that, so far as minerals go, South Africa is now living, not on her income, but on her capital, and that in twentyfive years half the capital may be gone.

There are other metals in the country besides the precious ones. The presence of extensive coal-beds in the Transvaal and Natal has been a circumstance of the first importance for the profitable working of the Rand gold-beds, and may encourage the growth of some kinds of manufacture. ${ }^{1}$ Iron is abundant both in the Transvaal and in Mashonaland, and has been found in many other districts, often in the neighbourhood of coal. It is not worked now, because all iron goods can be obtained more cheaply from Europe; but it may one day grow into an industry, as copper-mining already has in Little Namaqualand on the west coast.

The mention of coal and iron brings us to another branch of the subject - the possibility of establishing manufactures which may become a source of wealth and the support of an industrial population. At

${ }_{1}$ The Transvaal coal-fields are said to extend over 56,000 square miles; there is also a coal-field in the eastern part of Cape Colony, near the borders of the Orange Free State. 
present the manufactures are insignificant. All the textile goods, for instance, nearly all the metal goods, and by far the larger part even of the beer and spirits (intended for the whites) and mineral waters consumed in the country come from Europe. The Boers in the two republics and the Boer element at the Cape have neither taste nor talent for this kind of industry, and such capital as exists is naturally attracted to mining enterprises. Nevertheless, it may be thought that as capital accumulates things will change, and that the English part of the population in the two British colonies will take to manufactures, as it has done in Australia. Let us see whether this is probable.

To enable South African manufacturers to compete on a large scale with the established manufacturing countries, such as those in north-western Europe or north-eastern America, three things are needed-a large market, cheap sources of mechanical power, cheap and efficient labour. Of these the first is at present wanting, and even should the growth of the Rand mining district raise the white population of the two colonies and two republics from something over 700,000 to $1,200,000$, that number of consumers will be still too small to encourage the expenditure of any large capital in endeavouring to produce articles which the immense manufacturing establishments of Europe, working for populous markets, can turn out more cheaply. As to mechanical forces, there are no rivers to give water-power; and though Natal, Zululand, and the 
Transvaal provide coal, the quality of the mineral is inferior to that obtainable in South Wales or Belgium or Pennsylvania. But the most important conditions for success are those connected with labour. In South Africa skilled labour is dear because scarce, and unskilled labour is dear because bad. As was explained in a preceding chapter, all rough, hard work is done by natives; not that white men could not, in the more temperate regions, perfectly well do it, but because white men think it beneath them and only fit for blacks. Now black labour is seldom effective labour. The mixed race called "Cape boys" are good drivers, and quite fit for many kinds of railway work. They are employed in the building trades and in sawmills, and to some extent in such trades as bootmaking. The Kafirs of the eastern province and of Natal are more raw than the "Cape boys." They make good platelayers on railways, and having plenty of physical strength, will do any sort of rough work they are set to. But they have no aptitude for trades requiring skill, and it will take a generation or two to fit them for the finer kinds of carpentry or metal-work, or for the handling of delicate machinery. Besides, they are often changeable and unstable, apt to forsake their employment for some trifling cause. Their wages are certainly not high, ranging from ten to twenty shillings a month, besides food, for any kind of rough outdoor work. Miners are paid higher, and a Malay mason will get from thirty to forty shillings a week; but a white labourer at 
twice the price would, for most kinds of work, be cheaper. Nor is it easy to get the amount of native labour that may be needed, for the Kafir prefers to till his own patch of ground or turn out his cattle on the veldt. The scale for white workmen is, of course, far higher, ranging from $£ 2$ IOs. to $£ 8$ a week, according to the nature of the work and the competence of the artisan. Such wages are nearly double those paid in England, treble those paid in some manufacturing districts of Germany or Belgium, higher even than those paid in the United States. It is therefore evident that, what with the badness of the cheaper labour and the dearness of the better, a manufacturer would, in South Africa, be severely handicapped in competing with either Europe or the United States. Protectionists may think that a high tariff on foreign manufactured goods would foster industrial undertakings in these colonies. Such a tariff would, however, need to be fixed very high to give the local factory a chanceso high, indeed, that it would excite serious opposition from the consumer. And, in point of fact, there has been hitherto no cry for a tariff to protect home manufactures, because so few people are at present interested in having it. Such protection as exists is directed to food-stuffs, in order to please the agricultural classes, and induce a wider cultivation of the soil; and the tariff on other goods is almost solely for revenue.

The conditions I have described may, and probably will, change as the industrial training of the 
natives improves and their aversion to labour declines under the pressure of increasing numbers and a reduction of the quantity of land available for them. But a review of the present state of things points to the conclusion that no great development of manufactures, and of a white population occupied in manufactures, is to be expected, at least for some time to come.

Three other observations must at this stage be made. Till very recently, South Africans had what the Psalmist desired-neither poverty nor riches. There were hardly any white paupers, because the substratum of population was black; and as few black paupers, because a Kafir needs nothing but food. On the other hand, there were no rich whites. The farmers, both agriculturists and ranchmen, lived in a sort of rude plenty, with no luxuries and very little money. Everybody was tolerably well off, nobody was wealthy. There were large stock-farms, as in Australia, but the owners of these farms did not make the immense gains which many Australian squatters and some American cattle-men have made. Accordingly, when capital was needed for the development of the mines it was obtained from home. A few successful residents did, no doubt, make out of the diamond fields large sums, which they presently applied to the development of the gold fields. But by far the greater part of the money spent in opening up mines, both on the Witwatersrand and elsewhere, has come from Europe, chiefly from England, but to a considerable 
extent also from France, Germany, and Holland. Accordingly, nineteen twentieths at least of the profits made by the miners are paid to shareholders in those countries, and not expended in South Africa. Even among those who have made fortunes out of diamonds or gold by their personal enterprise on the spot, the majority return to Europe and spend their incomes there. The country, therefore, does not get the full benefit, in the way either of payments for labour (except, of course, labour at the mines) or of increased consumption of articles, out of its mineral products, but is rather in the position of Mexico or Peru in the seventeenth century, when the bulk of the precious metals won from the mines went to Spain as a sort of tribute. There are at this moment probably not more than a dozen rich men, as Europe counts riches, resident in the country, and all of these are to be found either at Johannesburg or at Cape Town. Most of them will after a time betake themselves to Europe. Nor is there any sign that the number of local fortunes will increase; for the motives which draw men away from Johannesburg to Europe are likely to continue as strong in the future as they are at present.

Secondly, as the whites are not-except at Johannesburg, where the lavishness of a mining population is conspicuous-large consumers of luxuries, so the blacks are poor consumers of all save the barest necessaries of life. It is not merely that they have no money. It is that they have no 
wants, save of food and of a few common articles of clothing. The taste for the articles which civilised man requires is growing, as the traders in Bechuanaland have already begun to find, but it grows slowly, and is still in a rudimentary stage. The demand which South Africa is likely to offer either for home-made or for imported products must, therefore, be measured, not by the gross population, but by the white population, and, indeed, by the town-dwelling whites; for the Dutch farmer or ranchman, whether in the British colonies or in the Dutch republics, has very little cash in his pocket, and lives in a primitive way. It is only the development of the mines that makes South Africa a growing market for European goods.

Thirdly, there is not much European immigration, except of citizens ; and these go chiefly to the gold mines of the Rand. Few agriculturists come out, because farms have seldom been offered by any of the Governments on the same easy terms as those which prevail in Canada or New Zealand, and because the climate and the existence of a black population deter the agricultural classes of northern Europe. Although the Government of Cape Colony has little or no land obviously fit for tillage to dispose of, because all the untilled area not absolutely barren has been appropriated for stock-farms, still there are districts on the south coast of Cape Colony, as well as in Natal and in the healthy uplands of Mashonaland, which Englishmen or Germans might cultivate with the assistance (in the hotter parts) of

$$
\text { o o }
$$


a little native labour, and which Italians or Portuguese might cultivate by their own labour, without native help. The Germans who were brought out in 1856 throve in body and estate on the farms which they tilled with their own hands near Grahamstown. Nevertheless, few agricultural immigrants enter, partly, no doubt, because so much of the land is held by a comparatively small number of persons, and reserved by them (as just observed) for pastoral purposes only. Neither do men go from Europe to start ranching, for the pastoral lands are taken up, except in those wilder regions where no one could thrive without some previous experience of the country. The settling of the newer parts of the country, such as those between the Zambesi and the tropic of Capricorn, is chiefly carried on by the Boers of the Transvaal, and, to a less extent, of the British colonies; for the Boers retain their passion for trekking out into the wilderness, while the English, with few exceptions, like to keep within reach of one another and of civilisation. Accordingly, the country receives comparatively few recruits from rural Europe, and its agricultural population grows only by natural increase. There are probably more natives of India to-day tilling the soil in Natal alone than the whole number of agriculturists who have come from Europe in the last thirty years. Legislation which should attract such agriculturists by the offer of tillage farms of moderate size would be a great benefit to the colonies. 
We may now endeavour to sum up the facts of the case, and state the conclusions to which they point.

South Africa is already, and will be to an increasing extent, a country of great mineral wealth. It is only in the diamond fields, especially those of Kimberley, and in the gold fields of the Witwatersrand, that this wealth has as yet been proved to exist, so far as regards precious stones and precious metals, but it may exist also in many other districts. It is not confined to precious stones and metals, and when these have been exhausted, copper, iron, and coal may continue to furnish good returns to mineowners and plenty of employment to work-people. The duration of the gold fields generally is uncertain, but those of the Witwatersrand will last for at least half a century, and will maintain for all that period an industrial population and a market for commodities which, though small when measured by the standard of the northern hemisphere, will be quite unique in Africa south of the equator.

South Africa is, and will continue to be, a great grazing country; for nearly all of its vast area is fit for live stock, though in large regions the proportion of stock to the acre must remain small, owing to the scarcity of feed. It will therefore continue to export wool, goats' hair, and hides in large quantities, and may also export meat, and possibly dairy products.

South Africa has been, is, and will probably continue to be for a good while to come, a country in which only a very small part of the land is tilled, 
and from which little agricultural produce, except fruit, sugar, and perhaps tobacco, will be exported. Only two things seem likely to increase its agricultural productiveness. One of these is the discovery of some preservative against malarial fever which might enable the lowlands of the east coast, from Durban northward, to be cultivated much more largely than they are now. The other is the introduction of irrigation on a large scale, an undertaking which at present would be profitable in a few places only. Whether in future it will be worth while to irrigate largely, and whether, if this be done, it will be done by companies buying and working large farms or by companies distributing water to small farmers, as the government distributes water in Egypt and some parts of India, are questions which may turn out to have an important bearing on the development of the country, but which need not be discussed now.

South Africa has not been, and shows no sign of becoming, a manufacturing country. Water power is absent. Coal is not of the best quality. Labour is neither cheap nor good. Even the imposition of a pretty high protective tariff would not be likely to stimulate the establishment of iron-works or -foundries on a large scale, nor of factories of textile goods, for the local market is too small to make competition with Europe a profitable enterprise. In these respects, as in many others, the conditions, physical and economic, differ so much from those of the British North American 
or Australian colonies that the course of industrial development is likely to be quite different from what it has been there.

From these conclusions another of great importance follows. The white population will remain scanty in proportion to the area of the country. At present, it is, in the two British colonies and the two Dutch republics, only about one and a half persons to the square mile, while over the other territories it is incomparably smaller.

The country will probably remain, so long as present agricultural conditions continue, a wilderness, with a few oases of population scattered at long distances from one another. The white inhabitants will, moreover, continue to be very unequally distributed. At present, of a total population in the last mentioned four states of about 730,000 , more than one fourth lives in the mining district of the Rand; one sixth is found in the five principal seaports on the southern and south-eastern coast; the remaining seven twelfths are thinly dispersed over the rest of the country in solitary farms or villages, or in a very few small towns, the largest of which, Kimberley, has only 10,000 inhabitants. The only towns that are growing are those five seaports, and Johannesburg with its tributary mining villages. Assuming the present growth of the Rand to continue, it may have in ten years about 500,000 whites, which will be not much less than a half of the then white population of the whole country. Stimulated by the trade which the 
Rand will supply, the five seaports will probably also grow; while elsewhere population may remain almost stationary. Unless the gold reefs of the country beyond the Limpopo turn out well and create in that region miniature copies of the Rand district, there seems no reason to expect the total number of whites to reach $1,200,000$ in less than twenty years. After that time growth will depend upon the future of agriculture, and the future of agriculture depends on so many causes independent of South Africa that it would be unsafe to make any predictions regarding it. I know some South Africans, able men, who think that the day will come when the blacks will begin to retire northward, and a large white population will till their own farms by their own labour, with the aid of irrigation. Of the advent of such a day there are no present signs, yet stranger changes have happened in our time than this change would be. Other South Africans believe that minerals not less valuable than those which the last twenty years have revealed are likely to be discovered in other places. This also may happen,- South Africa, it has been said, is a land of surprises,-and if it does happen there may be another inrush like that which has filled the Rand. All that one can venture to do now is to point out the probable result of the conditions which exist at this moment; and these, though they point to a continued increase of mineral production, do not point to any large or rapid increase of white inhabitants. 
Twenty years hence the white population is likely to be composed in about equal proportions of urban and rural elements. The urban element will be mainly mining, gathered at one great centre on the Witwatersrand, and possibly at some smaller centres in other districts. The rural element, consisting of people who live in villages or solitary farm-houses, will remain comparatively backward, because little affected by the social forces which work swiftly and potently upon close-packed industrial communities, and it may find itself very different in tone, temper, and tendencies from its urban fellow-citizens. The contrast now so marked between the shopkeeper of Cape Town and the miner of Johannesburg on the one hand, and the farmer of the Karroo or the northern Transvaal on the other, may be then hardly less marked between the two sections of the white population. But these sections will have one thing in common. Both will belong to an upper stratum of society; both will have beneath them a mass of labouring blacks, and they will therefore form an industrial aristocracy resting on Kafir labour. 


\section{CHAPTER XXVII}

\section{REFLECTIONS AND FORECASTS}

In preceding chapters I have endeavoured to present a picture of South Africa as it stands to-day, and to sketch the leading events that have made its political conditions what they are. Now, in bringing the book to a close, I desire to add a few reflections on the forces which have been at work, and to attempt the more hazardous task of conjecturing how those forces are likely to operate in the future.

The progress of the country, and the peculiar form which its problems have taken, are the resultant of three causes. One of these is the character which nature has impressed upon it. Of this I have already spoken (Chapter VI.), pointing out how the high interior plateau, with its dry and healthy climate, determined the main line of European advance and secured the predominance, not of the race which first discovered the country, but of the race which approached it, far later in time, from its best side. It is also in this physical character that one must seek the explanation of the 
remarkably slow progress of the country in wealth and population. South Africa began to be occupied by white men earlier than any part of the American continent. The first Dutch settlement was but little posterior to those English settlements in North America which have grown into a nation of seventy-five millions of people, and nearly a century and a half prior to the first English settlements in Australia. It is the unhealthiness of the east coast and the dryness of the rest of the country that are mainly accountable for this tardy growth-a growth which might have been still more tardy but for the political causes that drove the Boers into the far interior. And again, it is the physical configuration of the country that has made it, and is likely to keep it, one country. This is a point of cardinal importance. Though divided into two British colonies, with several other pieces of British territory, and two Boer republics, the habitable parts of South Africa form one community, all the parts of which must stand or fall together. The great plateau is : crossed by no lines of physical demarcation all the way from the Zambesi to the Hex River (some fifty miles north-east of Cape Town), and the coast regions are closely bound by economic ties to the plateau, which through them touches the outer world. Popular speech which talks of South Africa as one whole is scientifically right.

The two other causes that have ruled the fortunes and guided the development of the country have 
been the qualities and relations of the races that inhabit it, and the character of the Government which has sought from afar to control the relations of those races. These deserve to be more fully considered.

English statesmen have for more than fifty years been accustomed to say that of all the colonies of Great Britain none has given to the mother country so much disquiet and anxiety as South Africa has done. This is another way of expressing the fact which strikes the traveller - that no other British colony has compressed so much exciting history into the last sixty or seventy years. The reason is undoubtedly to be found in the circumstance that South Africa has had two sets of race questions to deal with : questions between the whites and the aborigines, questions between the Dutch and the English. It is this latter set of questions that have been the main thread of South African annals. Why have they proved so troublesome? Why are they so troublesome to-day, when we can look at them with a vision enlarged and a temper mellowed by wide experience? Partly from an element inherent in all race questions. They are not questions that can be settled on pure business lines, by an adjustment of the material interests of the parties concerned. They involve sentiment, and thus, like questions of religion, touch the deeper springs of emotion. And they spring from, or are involved with, incompatibilities of character which prevent the men of either stock from fully understanding, and therefore fully trusting, the men of the other. Suspicion, if 
not positive aversion, makes it difficult for two races to work together, even where the political arrangements that govern their relations are just and reason. able. But something may also be ascribed to certain malign accidents which blasted the prospect, once fair, of a friendly fusion between the Dutch and the English, peoples that seemed eminently fit to be fused. The British annexation of Cape Colony occurred at an unfortunate time. Had it happened thirty years earlier no difficulties would have arisen over the natives and slavery, because at that time the new philanthropy had not begun to influence English opinion or the British Government. Had it happened in later days, when steam had given quicker and more frequent ocean communication, Britain and the Colony would each have better known what the other thought and wished, and the errors that alienated the Boers might never have been committed. The period which followed the annexation was precisely the period in which the differences between English feeling and colonial feeling were most marked and most likely to lead to misunderstanding and conflict.

For there has been in the antagonism of the Boers and the English far more than the jealousy of two races. There has been a collision of two types of civilisation, one belonging to the nineteenth century, the other to the seventeenth. His isolation, not only in a distant corner of the southern hemisphere, but in the great, wide, bare veldt over which his flocks and herds roam, has kept the Boer fast bound in the ideas and habits of a past age, and he shrinks 
from the contact of the keen, restless modern man, with new arts of gain and new forms of pleasure, just as a Puritan farmer of Cromwell's day might shrink were he brought to life and forced to plunge into the current of modern London. Had the Boers been of English stock, but subjected to the same conditions as those which kept the seventeenth century alive in the country behind the Cape, they too would have resisted the new ways of the new rulers; but their identity of race and speech with those rulers would have abridged the struggle. It is the fact that the old Cape settlers had a language of their own, and a sense of blood-kinship to hold them together, that has enabled the Dutch element to remain cohesive, and given them an Africander patriotism of their own-a patriotism which is not Dutch, for they care nothing for the traditions of Holland, but purely Africander.

Their local position as half-nomadic inhabitants of a wide interior gave a peculiar character to that struggle between the mother country and her colonists which has arisen more than once in British history. They were so few and so poor, as compared with the people of the thirteen colonies of the North American coast in 1776 , that it was useless for them to rebel and fight for independence, as those colonies had done. On the other hand, they were not, like the French of lower Canada, rooted in the soil as agriculturists. Hence a middle course between rebellion and submission offered itself. That course was secession. They renounced not 
only their political allegiance, but even the very lands where they dwelt, seeking the protection of the desert as other emigrants before them had sought that of the ocean. Thus again, and more completely, isolated since 1836 , the emigrant Boers, and especially those of the Transvaal, have been able to retain their old ways for sixty years longer, and have grown more anti-English than ever. On the other hand, the English of the Colony, whose English sentiment was quickened by these events, have remained more thoroughly English than those of most British colonies, and have never conceived the idea of severing their own connection with the mother country.

That the emigrant Boers became republicans was due rather to circumstance than to conscious purpose. A monarch they could not have, because there was no one designated for the place, as well as because they had the instinct of general disobedience. But for a long time they tried to rub along with no more government or leadership than the needs of war required. Seldom has any people been so little influenced by abstract political ideas, yet seldom has a people enjoyed so perfect an opportunity of trying political experiments and testing the theories of political philosophers. But the Boers were, and are still, a strictly practical people. Their houses give them cover from sun and rain, but nothing more; there is little comfort and no elegance. So their institutions were the fewest and simplest under which men have ever governed themselves. It is therefore 
no theoretical attachment to democracy that has helped the Boers to resist the English; it is merely the wish to be left alone, and a stubbornness of will that made independence seem more desirable the more it was threatened.

Even this admirable stubbornness would hardly have carried them through but for their dispersion over vast spaces. That dispersion, while it retarded their political growth and social progress, made them hard to reach or to conquer. The British Government despaired of overtaking and surrounding them, for they were scattered like antelopes over the lonely veldt; and there was a still vaster and equally lonely veldt behind them into which they could retire. To pursue them seemed a wild-goose chase, and a costly one, in which there was much to spend and little to gain. Thus their weakness has proved their strength, and the more settled they become in the future, the less can they hope to escape the influences they have so long resisted.

But for the maintenance of the sentiment of Boer nationality by the two Boer republics, the antagonism of Dutch and English in Cape Colony would have ere now died out, for there has been little or nothing in colonial politics to sustain it. The interests of the farmers of both stocks are identical, their rights are in all respects the same, and the British Government has been perfectly impartial. The Boers in the Colony are good citizens and loyal subjects. It is only the character of the country and the conditions of their pastoral life that have retarded their 
social fusion with the English, as it is only the passions aroused by the strife of Boers and Englishmen in the Transvaal that evoked in $\mathrm{I} 88 \mathrm{I}$, and have again evoked in 1896 , a political opposition between the races. Fortunately, the sentiments of the Dutch have possessed a safe outlet in the colonial Parliament. The wisdom of the policy which gave responsible government has been signally vindicated; for, as constitutional means have existed for influencing the British Government, feelings which might otherwise have found vent in a revolt or a second secession have been diverted into a safe channel.

The other set of race troubles, those between white settlers and the aborigines of the land, have been graver in South Africa than any which European governments have had to face in any other new country. The Red Men of North America, splendidly as they fought, never seriously checked the advance of the whites. The revolts of the aborigines in Peru and Central America were easily suppressed. The once warlike Maoris of New Zealand have, under the better methods of the last twenty-five years, become quiet and tolerably contented. Even the French in Algeria had not so long a strife to maintain with the Moorish and Kabyle tribes as the Dutch and English had with the natives at the Cape. The south-coast Kafirs far outnumbered the whites, were full of courage, had a rough and thickly wooded country to defend, and were so ignorant as never to know when they were beaten. A more intelligent race might have sooner 
abandoned the contest. The melancholy chapter of native wars seems to be now all but closed, except perhaps in the far north. These wars, however, did much to retard the progress of South Africa and to give it a bad name. They deterred many an English farmer from emigrating thither in the years between I810 and I870. They annoyed and puzzled the home government, and made it think the Colony a worthless possession, whence little profit or credit was to be drawn in return for the unending military expenditure. And they gave the colonists ground for complaints, sometimes just, sometimes unjust, against the home government, which was constantly accused of parsimony, of shortsightedness, of vacillation, of sentimental weakness, in sending out too few troops, in refusing to annex fresh territory, in patching up a hollow peace, in granting too easy terms to the natives.

Whoever reviews the whole South African policy of the British Government during the ninety years that have elapsed since 1806 cannot but admit that many errors were committed. Many precious opportunities for establishing British authority on a sécure basis were lost. Many things were done imperfectly, and therefore had to be done over and over again, which it would have been cheaper as well as wiser to have finished off at once. Many steps, prudent in themselves, and dictated by excellent motives, were taken at a moment and in a way which made them misunderstood and resisted. Reflecting on these mistakes, one sometimes wonders 
that the country was not lost altogether to Britain, and thinks of the saying of the old Swiss statesman : Hominum negligentia, Dei providentia, regitur Helvetia. It may nevertheless be truly said for the British Government that it almost always sought to act justly, and that such advances as it made were not dictated by an aggressive spirit, but (with few exceptions) compelled by the necessities of the case. And it must not be forgotten that, as all home governments err in their control of colonies-Spain, Portugal, and France have certainly erred in their day far more fatally than England-so many of the errors which now most startle us in the annals of South Africa were all but inevitable, because the wisest man could not have foreseen the course which things have in fact taken. Whoever tries to look at the events of sixty, thirty, or even twenty years ago with the eyes of those times, and remembers that Colonial Ministers in England had to consider not only what they thought best, but what they could get the uninstructed public opinion of their own country to accept, will be more indulgent than the colonists are in their judgment of past mistakes. For instance, it is apt to be forgotten that the Cape was not occupied with a view to the establishment of a European colony, in our present sense of the word. The Dutch took it that they might plant a cabbage-garden; the English took it that they might have a naval station and half-way house to India. Not till our own time did people begin to think of it as capable of supporting a great civilised 
community and furnishing a new market for British goods; not till 1869 was it known as a region whence great wealth might be drawn. Hence Britain, which during the first half of this century was busy in conquering India, in colonising Australasia, and to setting things to rights in Canada, never cared to bend her energies to the development of South Africa, then a less promising field for those energies, spent no more money on it than she could help, and sought to avoid the acquisition of new territory, because that meant new troubles and new outlays.

The views of colonial policy which prevailed in England down till about 1870 were very different from those which most of us now hold. The statesmen of the last generation accepted that consilium coercendi intra terminos imperii which, according to Tacitus, Augustus held sound for an empire less scattered than is that of Britain. They thought that Britain had already more territory than she could hope to develop and (in the long run) to govern; and they therefore sought to limit rather than increase her responsibilities. And they believed, reasoning somewhat too hastily from the revolt of the North American colonies, that as soon as the new English communities to which self-government had been, or was in due course to be granted, reached a certain level of wealth and population they would demand and receive their independence. That the fruit would fall off the old tree as soon as it was ripe was the favourite metaphor employed to convey 
what nearly all publicists took to be an obvious truth. No one stated it so trenchantly as Disraeli when he wrote: "These wretched colonies will all be independent too in a few years, and are a millstone round our necks ;" but the dogma was generally accepted by politicians belonging to both the great parties in the state. Those, moreover, were days in which economy and retrenchment were popular cries in England, and when it was deemed the duty of a statesman to reduce as far as possible the burdens of the people. Expenditure on colonial wars and on the administration of half-settled districts was odious to the prudent and thrifty contemporaries or disciples of Sir Robert Peel and Richard Cobden. Accordingly, the chief aim of British statesmen from I 830 till I 870 was to arrest the tide of British advance, to acquire as little territory as possible, to leave restless natives and emigrant Boers entirely to themselves. Desperate efforts were made to stop the Kafir wars. We can now see that the tendency -one may almost call it a law of nature-which everywhere over the world has tempted or forced a strong civilised power to go on conquering the savage or half-civilised peoples on its borders, the process that has carried the English all over India, and brought the Russians from the Volga to the Pamirs in one direction and to the mouth of the Amur in another, was certain to compel the British Government to subdue and annex one Kafir tribe after another until either a desert or the territory of some other civilised state was reached. But fifty years 
ago this was not clearly perceived; so the process, which might have inflicted less suffering if it had been steadily and swiftly carried through, went on slowly and to the constant annoyance of statesmen at home.

It was the same as regards the great plateau and the Boer emigrants who dwelt there. Not from any sympathy with their love of independence, but because she did not want the trouble of pursuing and governing them and the wide lands they were spread over, England resolved to abandon the interior to them. In $185^{2}$ and I 854 she made a supreme effort to check her own onward career, first by recognising the independence of the Transvaal emigrants whose allegiance she had theretofore claimed, then by actually renouncing her rights to the Orange River Sovereignty and to those within it who desired to continue her subjects. What more could a thrifty and cautious and conscientious country do? Nevertheless, these good resolutions had to be reconsidered, these self-denying principles forgone. Circumstances were too strong for the Colonial Office. In I 869 it accepted the protectorate of Basutoland. In I $87 \mathrm{I}$ it yielded to the temptation of the diamond fields, and took Griqualand West. Soon after it made a treaty with Khama, which gave the British a foothold in Bechuanaland. In 1877 it annexed the Transvaal. By that time the old ideas were beginning to pass away, and to be replaced by new views of the mission and destiny of Britain. The wish of the British Government to stand still had been combated all along by powerful inducements 
to move on. The colonists always pressed for an advance of the frontier. The Governor usually pressed for it. The home government was itself haunted by a fear that if it abandoned positions of vantage its successors might afterwards have reason to rue the abandonment. These were the considerations that drove British statesmen to the most momentous forward steps that were taken. Two things, and two only, were really vital to British interests-the control of the coast, and the control of an open road to the north. Accordingly, the two decisive steps were the occupation of Natal in I842-3, which shut off the Boers from the sea, and the taking of Griqualand West in I87 I (followed by the taking of southern Bechuanaland in I884), which secured between the Transvaal on the one side and the Kalahari Desert on the other a free access to the great northern plateau.

The tide of English opinion began to turn about I 870 , and since then it has run with increasing force in the direction of what is called imperialism, and has indeed in some cases brought about annexations that are likely to prove unprofitable, because the territory acquired is too hot and unhealthy to be fit for British settlement. The strides of advance made in $1884-5$ and 1890 have been as bold and large as those of earlier days were timid and halting ; and the last expiring struggles of the old policy were seen in I 884, when Lord Derby, who belonged to the departing school, yielded a new convention to the importunity of the Transvaal Boers and allowed Germany to establish herself in Damaraland. But 
it is due to Britain, which has been accused, and so far as regards South Africa unjustly accused, of aggressive aims, to recall the fact that she strove for many years to restrict her dominion, and did not cease from her efforts until long experience had shown that it was hard to maintain the old policy, and until the advent on the scene of other European powers, whom it was thought prudent to keep at a distance from her own settled territories, impelled her to join in that general scramble for Africa which has been so strange a feature of the last two decades.

There have been moments, even since the occupation of two points so important as Basutoland (in I869) and Griqualand West (in I87I) when it has seemed possible that South Africa might become Dutch rather than English, such is the tenacity of that race, and so deep are the roots which its language has struck. With the discovery of the Witwatersrand gold fields, drawing a new body of English immigrants into the country, that possibility seems to have passed away. The process of territorial distribution is in South Africa now complete. Every colony and state has become limited by boundaries defined in treaties. Every native tribe has now some legal white superior, and no native tribe remains any longer formidable. The old race questions have passed, or are passing, into new phases. But they will be at least as difficult in their new forms as in their old ones. I will devote the few remaining pages of this 
book to a short consideration of them and of the other problems affecting the future of South Africa with which they are involved.

Reasons have been given in a preceding chapter for the conclusion that both the white and the black races are likely to hold their ground over all the country, and that the black race will continue to be the more numerous. Assuming the conditions of agriculture to remain what they are at present, and assuming that the causes which now discourage the establishment of large manufacturing industries do not pass away, there will probably be for the next seventy years a large white population on the gold fields and at the chief seaports, and only a small white population over the rest of the country. Even should irrigation be largely introduced, it would be carried on chiefly by black labourers. Even should low wages or the discovery of larger and better deposits of iron and coal stimulate the development of great manufacturing industries, still it is a black rather than a white population that would be therewith increased. Various causes may be imagined which would raise or reduce the birthrate and the infant death-rate among the natives, so that one cannot feel sure that the existing proportion between them and the whites will be maintained. But if we regard the question from the point of view of labour, and take the natives to represent that part of the community which in Europe does the harder and less skilled kinds of work, both in country and in town, it may be con- 
cluded that they will continue to form the majority even where they live among the white people, without taking account of those areas where they, and they alone, are settled on the land. It is, however, impossible to conjecture how large the majority will be.

The Kafirs, as has been already suggested, will gradually lose their tribal organisation and come to live like Europeans, under European law. They will become more generally educated, and will learn skilled handicrafts ; many-perhaps, in the long run, all-will speak English. They will eventually cease to be heathens, even if they do not all become Christians. This process of Europeanisation will spread from south to north, and may probably not be complete in the north-at any rate, in the German and Portuguese parts of the north-till the end of next century. But long before that time the natives will in many places have begun to compete (as indeed a few already do) with the whites in some kinds of well-paid labour. They will also, being better educated and better paid, have become less submissive than they are now, and a larger number of them will enjoy the suffrage.

What will be the relations of the two races when these things have come about, say within two or three generations? Consider what the position will then be. Two races will be living on the same ground, in close and constant economic relations, both those of employment and those of competition, speaking the same language and obeying the same 
laws, differing, no doubt, in strength of intelligence and will, yet with many members of the weaker race superior as individual men to many members of the stronger. And these two races, separated by the repulsion of physical differences, will have no social intercourse, no mixture of blood, but will each form a nation by itself for all purposes save those of industry and perhaps of politics. There will, no doubt, be the nexus of industrial interest, for the white employer will need the labour of the blacks. But even in countries where no race differences intervene, the industrial nexus does not prevent bitter class hatreds and labour wars.

That such a state of things will arrive is rendered probable not only by the phenomena to be observed to-day in South Africa, but by the experience of the Southern States of the American Union, where almost exactly what I have described has come to pass, with the addition that the inferior race has in theory the same political rights as the superior. How will the relations of two races so living together be adjusted? The experience of the Southern States is too short to throw much light on this problem. It is, however, a painful experience in many respects, and it causes the gravest anxieties for the future. Similar anxieties must press upon the mind of any one who in South Africa looks sixty or eighty years forward: and they are not diminished by the fact that in South Africa the inferior race is far more numerous than the superior. But although the position I have 
outlined seems destined to arrive, it is still so distant that we can no more predict the particular form its difficulties will take than the mariner can describe the rocks and trees upon an island whose blue mountains he begins to descry on the dim horizon. Whatever those difficulties may be, they will be less formidable if the whites realise, before the coloured people have begun to feel a sense of wrong, that their own future is bound up with that of the natives, and that the true interests of both races are in the long run the same.

Although the facts we have been considering suggest the view that the white population of South Africa will be very small when compared with that of the North American or Australasian colonies, they also suggest that the whites will in South Africa hold the position of an aristocracy, and may draw from that position some of the advantages which belong to those who are occupied only on the higher kinds of work, and have fuller opportunities for intellectual cultivation than the mass of manual labourers enjoy. A large part of the whites will lead a country life, directing the field work or the ranching of their servants. Those who dwell in the towns will be merchants or employers of labour or highly skilled artisans, corresponding generally to the upper and middle strata of society in North America or Australia, but probably with a smaller percentage of exceptionally wealthy men. There is, of course, the danger that a class may spring up composed of men unfit for the higher 
kinds of work, and yet too lazy or too proud to work with their hands; and some observers profess to discover signs of the appearance of such a class. If its growth can be averted the conditions for the progress and happiness of the white race in South Africa seem very favourable; and we are approaching an age of the world when the quality of a population will be more important than its quantity.

In this forecast I have said nothing of the gold mines, because they will not be a permanent factor. The present gold fever is a fleeting episode in South African history. Gold has, no doubt, played a great part in that history. It was the hope of getting gold that made the Portuguese fix their first post at Sofala in I 505, and that carried the English pioneers to Mashonaland in 1890 . It was the discovery of the banket gold beds on the Witwatersrand in 1885 that finally settled the question whether South Africa was to be an English or a Dutch country. Yet gold mining will pass away in a few decades, for the methods which the engineer now commands will enable him within that time to extract from the rocks all the wealth now stored up in them. A day will come when nothing will be left to tell the traveller of the industry which drew hundreds of thousands of men to a barren ridge, except the heaps of refuse whose ugliness few shrubs will, in that dry land, spring up to cover. But South Africa will still be a pastoral and agricultural country, and none the less happy because the gold is gone. 
CHAP.

Neither have I said anything as to the influence of any foreign power or people upon the South Africans, because they will to all appearance remain affected in the way of literature and commerce, as well as of politics, by Britain only. There is at present no land trade from British or Boer States with the territories of Germany and the Congo State which lie to the north; and spaces so vast, inhabited only by a few natives, lie between that no such trade seems likely to arise for many years to come. Continental Europe exerts little influence on South African ideas or habits; for the Boers, from causes already explained, have no intellectual affinity with modern Holland, and the Germans who have settled in British territories have become quickly Anglified. Commerce is almost exclusively with English ports. Some little traffic between Germany and Delagoa Bay has lately sprung up, aided by the establishment of a German line of steamers to that harbour. Vessels come with emigrants from India to Natal, though the Government of that colony is now endeavouring to check the arrival of any but indentured coolies; and there are signs that an important direct trade with the United States, especially in cereals and agricultural machinery, may hereafter be developed. In none of these cases, however, does it seem probable that commercial intercourse will have any considerable influence outside the sphere of commerce. With Australia it is different. Having ceased, since the opening of the Suez Canal, to be the halfway 
house to India, the Cape has become one of the halfway houses from Britain to Australasia. The outgoing New Zealand steamers touch there; grain is imported, although the high tariff restricts this trade, and many Australian miners traverse Cape Colony on their way to the Witwatersrand. A feeling of intercolonial amity is beginning to grow up, to which a happy expression was given by the Cape Government, when they offered financial assistance to the Australian colonies during the recent commercial crisis.

With the other great country of the Southern hemisphere there seems to be extremely little intercourse. Britain did not use, when she might have legitimately used, the opportunity that was offered her early in this century of conferring upon the temperate regions of South America the benefits of ordered freedom and a progressive population. Had the territories of the Argentine Republic (which now include Patagonia), territories then almost vacant, been purchased from Spain and peopled from England, a second Australia might have arisen in the West, and there would now be promise not only of commerce but ultimately of a league based upon community of race, language, and institutions between three great English-speaking States in the south temperate zone. That opportunity has, however, passed away; and southern South America, having now been settled by Spaniards and Italians, with a smaller number of Germans, seems destined to such fortunes as the Hispano- 
CHAP.

American race can win for her. But it may well be hoped that as trade increases between South Africa and Australia, there may come with more frequent intercourse a deepening sense of kinship and a fuller sympathy, inspiring to both communities, and helpful to any efforts that may hereafter be made to knit more closely together the Englishspeaking peoples all over the world.

Although the relations of the white race to the black constitutes the gravest of the difficulties which confront South Africa, this difficulty is not the nearest one. More urgent, if less serious, is the other race problem - that of adjusting the rights and claims of the Dutch and the English.

It has already been explained that, so far as Cape Colony and Natal are concerned, there is really no question pending between the two races, and nothing to prevent them from working in perfect harmony and concord. Neither does the Orange Free State provide any fuel for strife, since there both Boers and English live in peace and are equally attached to the institutions of their Republic. It is in the Transvaal that the centre of disturbance lies; it is thence that the surrounding earth has so often been shaken and the peace of all South Africa threatened. I have already described the circumstances which brought about the recent troubles in that State. To comment upon what has happened since the rising, to criticise either the attitude of the President or the various essays in diplomacy of the British Government, would be to enter that 
field of current politics which I have resolved to avoid. What may fitly be done here is to state the uncontroverted and dominant facts of the situation as it stands in the autumn of 1897 .

What are these facts? The Boer population of the Transvaal is roughly estimated at 65,000 , of whom about 24,000 are voting citizens. The Uitlanders, or alien population, five-sixths of whom speak English, are estimated at I80,000, of whom nearly one-half are adult males. These Uitlanders hold sixty-three per cent. of the landed and ninety per cent. of the personal property in the country. In December, I895, their number was increasing at the rate of one thousand per week through arrivals from Cape Town alone; and though this influx fell off for a time, while political troubles were checking the development of the mines, it rose again with the renewal of that development. Should the Deep Level mines go on prospering as is expected, the rate of immigration will be sustained, and within ten years there will probably be at least 500,000 Uitlanders in the Republic, that is to say, nearly eight times the number of the Boers.

The numerical disproportion between these excluded persons-a very large part of whom will have taken root in the country-and the old citizens will then have become overwhelming, and the claim of the former to enjoy some share in the government will be practically irresistible. The concession of this share may come before 1907-I incline to think it will —or it may come somewhat later. The 
CHAP.

precise date is a small matter, and depends upon personal causes. But that the English-speaking element will, if the mining industry continues to thrive, become politically as well as economically supreme, seems inevitable. No political agitation or demonstrations in the Transvaal, much less any intervention from outside, need come into the matter. It is only of the natural causes already at work that I speak, and these natural causes are sufficient to bring about the result. A country must, after all, take its character from the large majority of its inhabitants, especially when those who form that large majority are the wealthiest, most educated, and most enterprising part of the population.

Whether this inevitable admission of the newcomers to citizenship will happen suddenly or gradually, in quiet or in storm, no one can venture to predict. There are things which we can perceive to be destined to occur, though the time and the manner may be doubtful. But as it will be dictated by the patent necessities of the case, one may well hope that it will come about in a peaceable way and leave behind no sense of irritation in either race. Boers and Englishmen cannot in the Transvaal so easily blend and learn to work together as they have done in the Orange Free State, because they were in the latter State far less socially dissimilar. But the extension of the suffrage, while it will be followed by legislation beneficial to the mining industry, need not involve legislation harmful to the 
material interests of the Boer element. On the contrary, the Boers themselves will ultimately profit by any increase in the prosperity of the country. An improved administration will give a more assured status to the judiciary, as well as a better set of laws and better internal communications, advantages which will be helpful to the whole Republic.

That the change should come about peaceably is much to be desired in the interest not only of the Transvaal itself, but of all South Africa. The irritation of the Dutch element in Cape Colony, both in I88I and again in I896, was due to an impression that their Transvaal kinsfolk were being unfairly dealt with. Should that impression recur, its influence both on the Dutch of Cape Colony, and on the people of the Free State, whose geographical position makes their attitude specially important, would be unfortunate. The history of South Africa, like that of other countries nearer home, warns us how dangerous a factor sentiment, and especially the sense of resentment at injustice, may become in politics, and how it may continue to work mischief even when the injustice has been repented of. It is, therefore, not only considerations of magnanimity and equity, but also considerations of policy, that recommend to the English in South Africa and to the British Government an attitude of patience, prudence, and strict adherence to legal rights. They are entitled to require the same adherence from the Transvaal Government, but it is equally their interest not to depart from it themselves, and to avoid even the 
CHAP.

least appearance of aggression. The mistakes of the past are not irremediable. Tact, coolness, and patience-above all, patience-must gradually bring about that reconcilement and fusion of the two races to which, it can scarcely be doubted, South Africa will at last attain.

When, by the enfranchisement of the Uitlanders, the Transvaal has ceased to be a purely Boer State, questions will arise as to its relations with the other States of South Africa. Cape Colony and the Orange Free State, as well as Basutoland and the Bechuanaland Protectorate, already form a Customs Union, and they have long sought to induce the Transvaal and Natal to enter into it and thereby establish internal free trade throughout the country. Natal has hitherto refused, because she deems the tariff of the Customs Union too high; while the Transvaal people have desired to stand as much aloof as possible from Cape Colony, as well as to raise for themselves a revenue on imports larger than that which they would receive as partners in the Customs Union. A reformed Transvaal Government would probably enter the Customs Union; and this would usher in the further question of a confederation of all the States and Colonies of South Africa. That project was mooted by Sir George Grey (when Governor) more than thirty years ago, and was actively pressed by Lord Carnarvon (when Colonial Secretary) and Sir Bartle Frere between 1875 and 1880 . It failed at that time, partly owing to the annoyance of the Orange Free State at the loss of the diamond fields 
in I87 I, partly to the reluctance of the Dutch party at the Cape, who were roused against the proposal by their Transvaal kinsfolk. The desire for it is believed to have moved some of those who joined in the Transvaal Uitlander movement of I895-96, and no one can discuss the future of the country without adverting to it. The advantages it offers are obvious. A confederation would render in Africa services similar to those which the federal system has rendered in the United States and Canada, and which are expected by the colonial statesmen who are labouring to establish such a system in Australia. I heard not only railways and finance (including tariff and currency), but also commercial law and native questions, suggested as matters fit to be intrusted to a federal authority; while it seemed to be thought that the scope of such an authority should, on the whole, be narrower than it is under the Canadian Constitution, or under that of the United States. The love of local independence is strong in South Africa, but might be deferred to and appeased, as is being done in Australia, by appropriate constitutional provisions. So far, no fatal obstacle stands in the way; but a difficulty has been thought to arise from the fact that whereas Cape Colony, Natal, and the other British territories are part of the dominions of the British crown, the Orange Free State is an independent republic, and the Transvaal may be so when federation becomes a practical issue. "Can a federal tie," it is asked, "bind into one body communities some of which are republics, while 
CHAP.

others, though practically self-governing, are legally parts of a monarchy?"

To this it may be answered that there have been instances of such confederations. In the Germanic Confederation, which lasted from I8I5 till I866, there were four free republics, as well as many monarchies, some large, some small. The Swiss Confederation (as established after the Napoleonic wars) used to contain in the canton of Neuchatel, a member whose sovereign was the King of Prussia. And as it is not historically essential to the conception of a federal state that all its constituent communities should have the same form of internal government, so practically it would be possible, even if not very easy, to devise a scheme which should recognise the freedom of each member to give itself the kind of constitution it desired. Such an executive head as either the President of the United States or the Governor-General of Canada, is not essential to a federal system. The name "confederation" is a wide name, and the things essential to it may be secured in a great variety of ways. The foreign policy of a South African Confederation is perhaps the only point which might raise considerations affecting the international status of the members of the Confederation; and as to this, it must be remembered that neither the Orange Free State nor the Transvaal can come into direct contact with any foreign power except Portugal, because neither has any access to the sea, or touches (save on the eastern border of the Transvaal) any non-British territory. 
Another remark occurs in this connection. The sentiment of national independence which the people of the Free State cherish, and which may probably survive in the Transvaal even when that state has passed from a Boer into an Anglo-Dutch republic, is capable of being greatly modified by a better comprehension of the ample freedom which the self-governing colonies of Britain enjoy. The nonBritish world is under some misconception in this matter, and does not understand that these colonies are practically democratic republics, though under the protection and dignified by the traditions of an ancient and famous monarchy. Nor has it been fully realised that the colonies derive even greater substantial advantages from the connection than does the mother country. The mother country profits, perhaps to some extent-though this is doubtful-in respect of trade, but chiefly in the sentiment of pride and the consciousness of a great mission in the world which the possession of these vast territories, scattered over the oceans, naturally and properly inspires. The colonies, on the other hand, have not only some economic advantages in the better financial credit they enjoy, but have the benefit of the British diplomatic and consular service all over the world and of the status of British citizens in every foreign country. It is also a political convenience to them to be relieved, by the presence of the Governor whom the mother country sends out as an executive figurehead of their Cabinet system, from the necessity of electing an executive chief, a convenience which those who 
know the trouble occasioned by Presidential elections in the United States can best appreciate. And, above all, the British colonies have the navy of Britain to defend them against molestation by any foreign power. It may be said that they have also the risk of being involved in any war into which Britain may enter. This risk has, however, never become a reality; for during the last eighty years no colony has ever been even threatened with attack by a foreign state, while during all that time the colonies have been relieved from the cost and trouble of maintaining the naval and military armaments which are needed to ensure their safety. Thus, even leaving sentiment aside, the balance of material advantage to the colonies is great and real ; while their self-government is complete, for the mother country never interferes with any matters of colonial concern, unless in the rare cases where a matter primarily local may affect the general relations and interests of the whole empire. When these facts have been fully realised in the Free State and the Transvaal, it may well be that those states will be ready to enter a confederation of which the British monarchy would be, as in Canada and (probably before long) in Australia, the protecting suzerain ; for there would be in that suzerainty no real infringement of the independence which the Free State has so happily enjoyed. It is premature to speculate now on the best form which a scheme for South African confederation may take. All that need here be pointed out is that the obstacles now perceived are not in- 
surmountable obstacles, but such as may be overcome by a close study of the conditions of the problem, and by reasonable concessions on the part of South African statesmen in the different states concerned.

These observations are made on the assumption that the South African colonies will desire to maintain their political connection with the mother country. It is an assumption which may safely be made, for nowhere in the British empire is the attachment to Britain more sincere. Strong as this feeling is in Canada and in Australasia, it is assuredly no less strong in South Africa. The English there are perhaps even more English than are the people of those other colonies. Those of Dutch origin, warm as is their Africander patriotism, have never been hostile to the British crown. And both English and Dutch feel how essential to them, placed as they are, is the protection of a great naval power. They have as near neighbours in the South Atlantic and Indian Oceans two great European powers bent on colonial expansion, and to either of whom, even apart from colonial expansion, such a position as Simon's Bay or Table Bay offers would be invaluable. Both the mother country, therefore, whose naval and commercial interests require her to retain the Cape peninsula, and her South African children, have every motive for cleaving to one another, and, so far as our eyes can pierce the mists of the future, no reason can be discerned why they should not continue so to cleave. The 
peoples of both countries are altogether friendly to one another. But much will depend on the knowledge, the prudence, the patience, the quiet and unobtrusive tact, of the home government.

While Britain continues to be a great naval power, the maintenance of her connection with South Africa will ensure the external peace of that country, which, fortunately for herself, lies far away in the southern seas, with no land frontiers which she is called on to defend. She may not grow to be herself as populous and powerful a state, as will be the Canadian or the Australian confederations of the future, for her climatic conditions do not promise so large an increase of the white race; but her people may, if she can deal wisely with the problems which the existence of the coloured population raises, become a happy and prosperous nation. They are exempt from some of the dangers which threaten the industrial communities of Europe and North America. The land they dwell in is favoured by nature, and inspires a deep love in its children. The stock they spring from is strong and sound; and they have carried with them to their new home the best traditions of Teutonic freedom and self-government. 



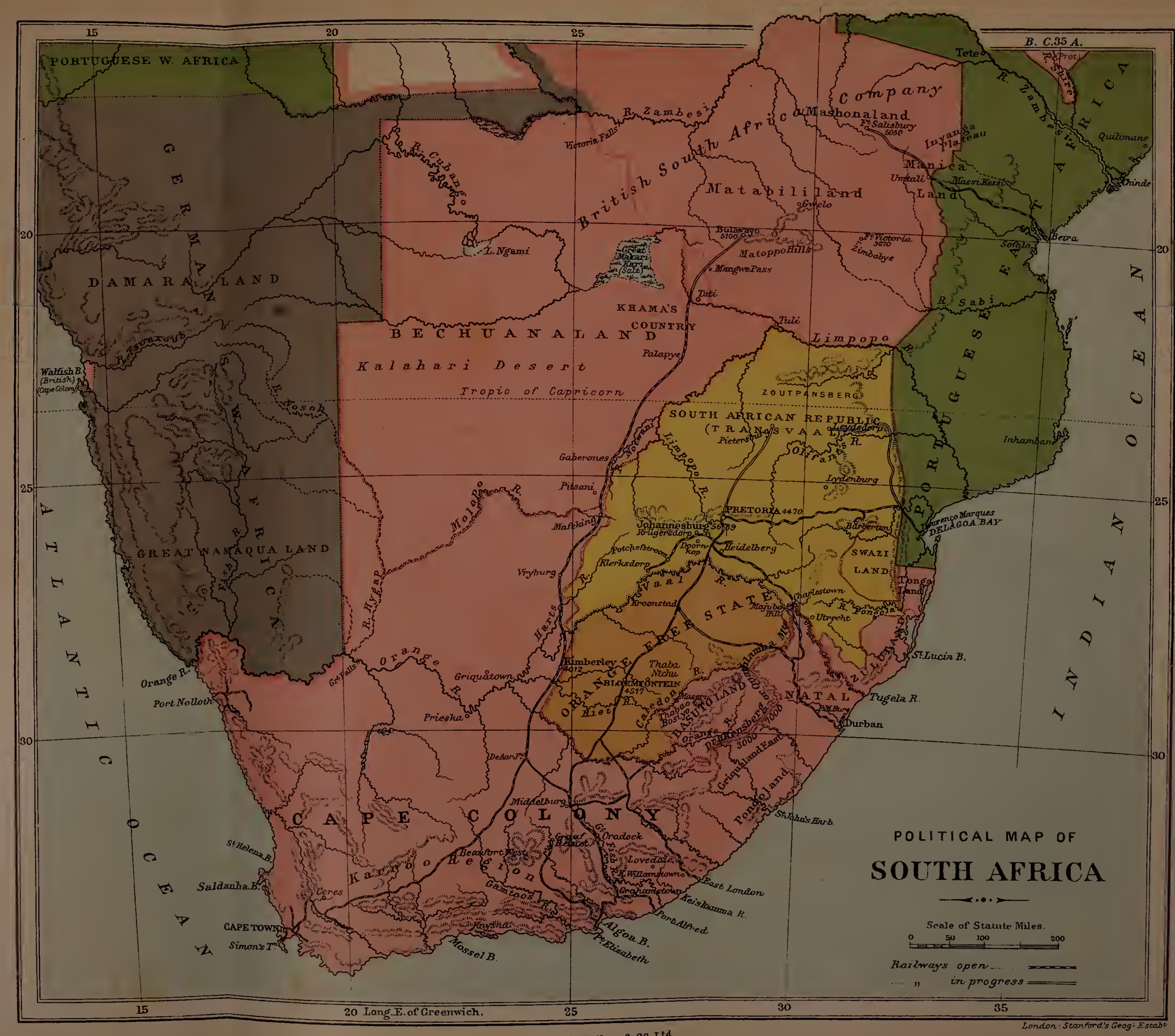

London : Macmillan \& Co, L L.d. 


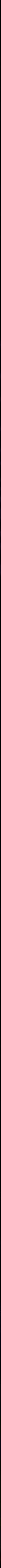





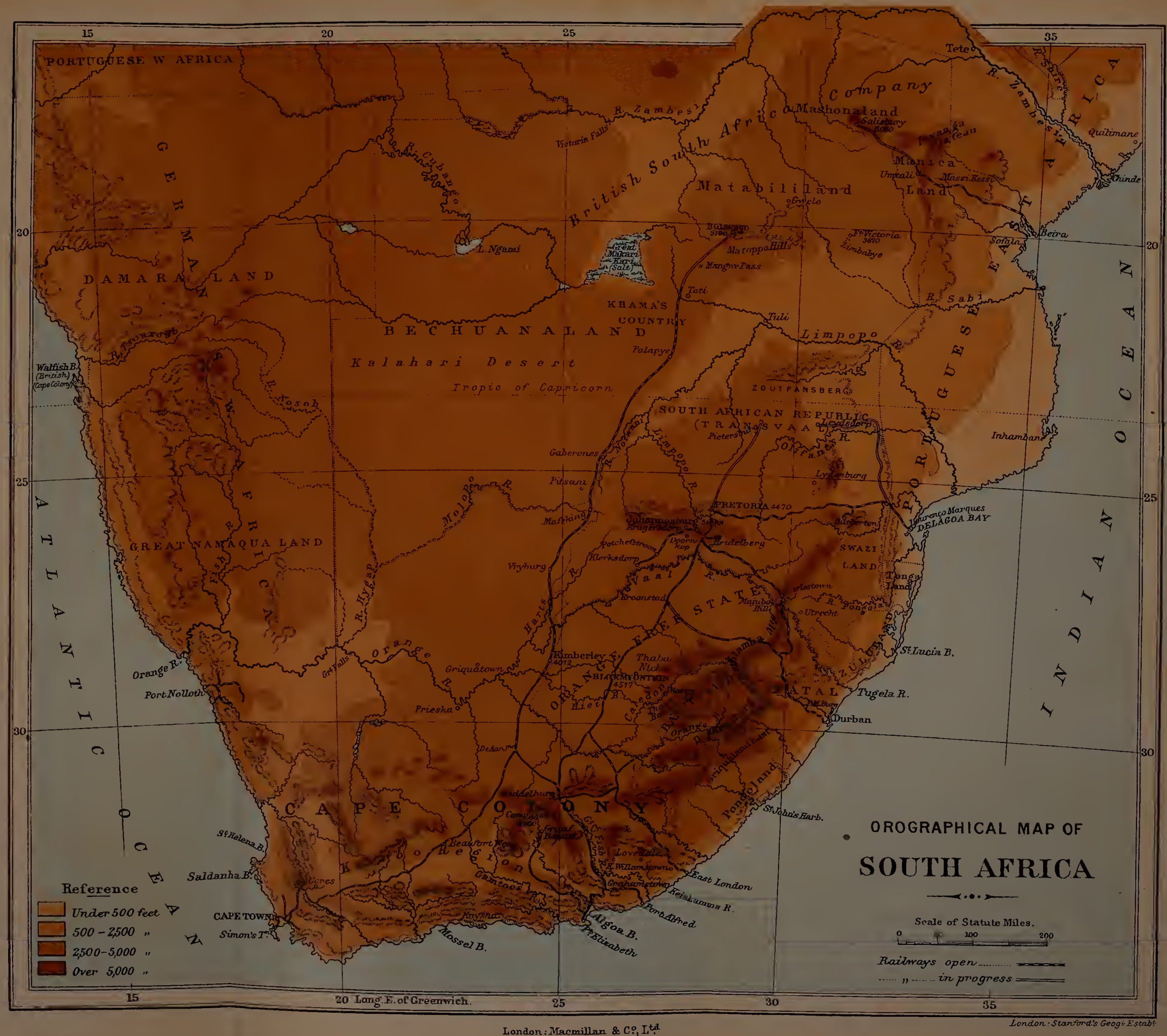





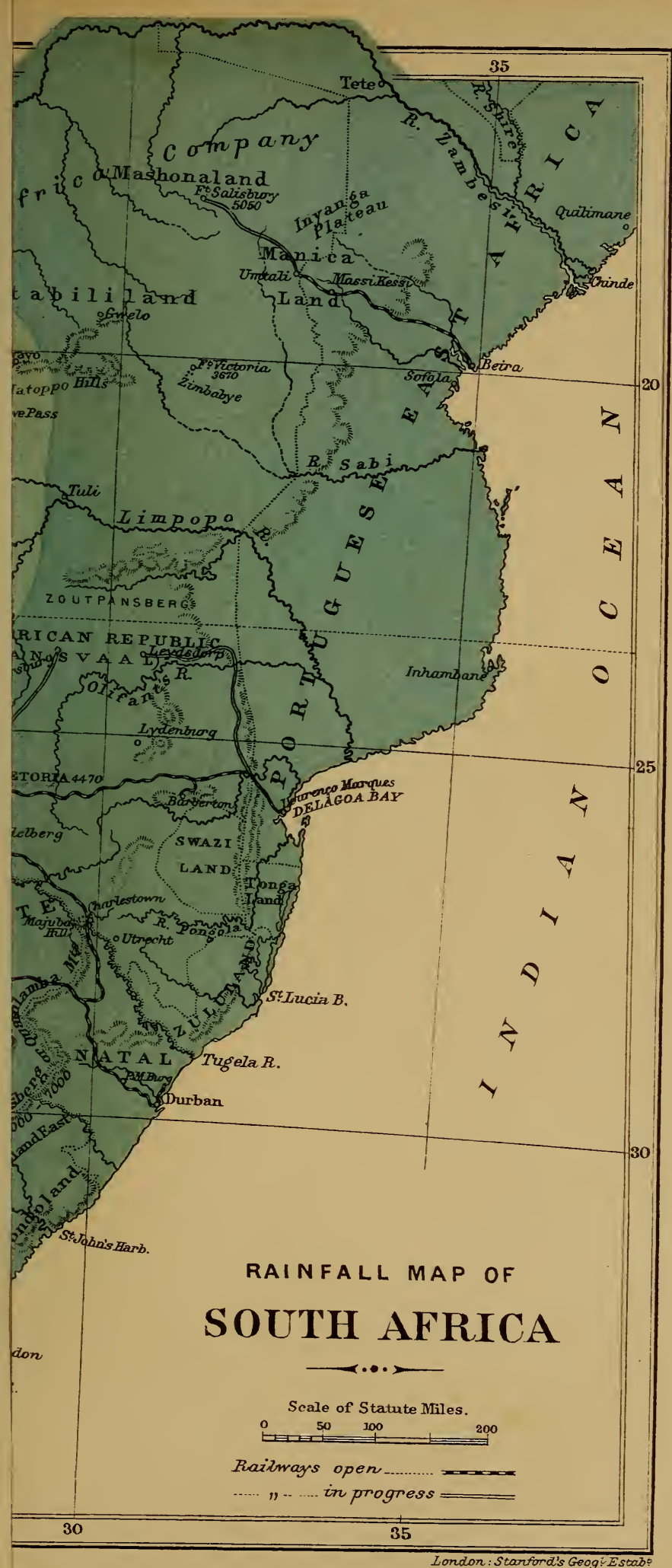






\section{INDEX}

\section{A}

\section{AFRICANDER, I 29}

Africander Bond, 502

Agricultural products, $544-547$

Algoa Bay, 136

Americans in the Transvaal, 519

Animals, wild, 20-25, I IO, I I I 329

Antelopes, 22

Antiquities, 83 et seq., 28I, 288, 3I I313

Ants, 317

Australian trees, 34,36

\section{B}

\section{Baboons, 25}

Ba-Mangwato, I I I , 260

Bantu tribes, $8 \mathrm{I}$

Basutoland, 3, 6o, 397, 428

Basutos, 103, 106, 154, 160, 161, 413, 4I 4, 419-428

Bechuanaland, 46, 205, 253, 256-268

Bechuanas, I03, 265-267

Beira, 225, 336, 337

Berea, 355

Bloemfontein; $144,159,160,163,390$

Boers, 67, I03, I09, I19, I 24, I4I, I44, I 46 , I47, I48-165, I85, 365, 507 , $525,535,536,571,572,591$

Brand (President), Sir John, 395

British Government, I34, I36, I47, I 48 et seq., I 84, 576, 580, 581

British South Africa Company, 212, $275,349,350,351,530-532$

British South Africa Company's territory, 47, 338-35I

Buffalo, 22

Bulawayo, 27 I et seq.

Burgers (President), I9I

Bushmen, 74, I03, I29, I3I, 4I3
C

Caledon River, 4I8, 420

Cape Colony (physical aspects), 37-40

Cape of Good Hope, 240

Cape Town, I7, 27, 60, 237

Cathcart, Sir George, 418

Cetewayo, 103, 185, 186, 198

Chimoyo, 324

Churches, $487,488,497$

Climate, 7, 8, I I, I4, 38-49, 293, 340

Coaches, 230

Colley, General Sir George, 198, 366, 367

Colonial policy, review of, $578-582$

Colonies of Britain, 597

Colour in South African landscapes, 62,316

Colour question, 433 et seq., 585, 590

Commerce, 588

Confederation (of South Africa), 183, 595

Constitution of Natal, 357

of Orange Free State, 394, 395

of Cape Colony, 49I-494

of Transvaal, $512,5^{13}$

Convention of London, 207

Crocodiles, 22, 257, 334

Crown Colonies, 435

Customs Union, 594

\section{D}

Damaraland, 4I, 212

Delagoa Bay, I44, I83, 224, 352-354

Dhlodhlo, 84, 88-90, 285, 287

Diamond-mines, 247, 249, 455, 549, $55^{\circ}$

Diaz, Bartholomew, 52, 120

Dingaan, I03, I42, 145

Dingiswayo, IOI

Dongas, 232, 324 
Drakensberg or Quathlamba Mountains, 3, 154,155

Durban, 147, 354

Dutch, 54, I 16, I 20, I 24-I 28 , I 31 , I34-I37, 140, I4I, 202, 203, 443, 475-477

Dutch East India Company, J26, I28, I 32-I 35, I69, I 7 I, I 74

Education, 485

Elandsfontein, 37I

Elephants, 2 I

F

$\mathrm{E}$

Fever, I4-I6, 327

Flora of South Africa, 26-36

of Maluti Mountains, 407

Fontesvilla, 330

Forests, 29-36

Frere, Sir Bartle, I86, 202 n., 42I

G

Gama, Vasco da, 52, I 20, I25, 352

Geology, 6

German Southwest Africa, 4I, 210, 2 I I

Germans, I 20, I 21 n., I67:

Ghost-worship, I09-I I 2, 3I I , 427, 474

Giraffes, 22

Gold-mines, 318, 319, 341, 372-380, $518,550,551,587$

Grass-fires, 289

Griqualand West, 182

Griquas, 159, I 79

Grondwet, I89, 449, 512, 514

Gungunhana, 104, 466

Gwelo, 29I

$\mathrm{H}$

Health, I I-I 7

Heat, 7, I0

Heaths, 27, 409

Hippopotamus, 21, 334

Hollanders, 516,526

Horse-Sickness, 230, 31 3

Horses, 266, 313, 408

Hottentots, I 29, I 35 , I 39

Huguenot immigrants, I 28

Immigration, $56 \mathrm{I}$

Indians, 302, 354, 363, 439

Invanga, 98,320
$\mathrm{J}$

Johannesburg, 218, 380-386, 51 I , 530,531

K

Kafirs, 78，100-118，148，149，308， $309,454,459-463,575,584$

Kalahari Desert, 24, 46, 75, 212

Karroo, 6, I 7, 28, 38, 39, 244

Khama, 206, 262-266, 445

Kimberley, I 7, 34, I 58, 245-252

Kruger (President), S. J. P., I44, I93, 198, 205, 208, 21 7, 386, 516, 529

\section{L}

Laing's Nek, 199, 365, 367

Language, 479

Laws relating to natives, $445-450$

Leopard, 19

Lerothodi, 403-405, 423

Limpopo River, 9, 257

Lion, 25, 267, 268

Livingstone, David, 54, 103, 190

Lo Bengula, 104, 212, 214, 215, 227, $271,273 n$.

Locusts, 288, 323, 328

Lovedale, 469

Lïderitz, 2 I0

\section{M}

Maceo, the Cuban leader, $124 n$.

Machacha, 407, 409, 4I I

Mafeking, 253, 254

Majuba Hill, I99, 365, 366

Makalanga or Makalaka, I00, 276, 298

Maluti Mountains, 40I, 406

Mangwe Pass, 268

Manicaland, 34I

Manufactures, 355,356

Mashonaland, $48,54,85,98,215,276$, 304

Massikessi, 323, 324

Matabili, 88, 97, 215, 216, 264, 272, $284,299,300$

Matabililand, 83, 90, 97, 216

Matoppo Hills, 269, 286

Missionaries, I 22, I39, I 58, 4I 8,427 , $464-474$

Molimo or Mlimo, I I I, I I3, I I4 $n$.

Monomotapa, I00

Montsioa, 254

Morija, 402, 403 
Moshesh, I 52, I 53, I 54, I 59, 404, 4I6, $4 \mathrm{I} 7,420,42 \mathrm{I}$

Mosilikatze, 145, 264, 27 I, 466

Mtali, 3 I6

Murrain among cattle, 279, 28o, 456

Mzila, I04, 32I

\section{N}

Namaqualand, 4I, 2 I2

Natal, 40, I47 - I52, I62, 356363

National Union, 517,528

Native character, $440,441,467,468$

Native political rights, $360,364,389$, 450

Native labour, 278, 281, 379, 380, 428, $429,437,438,446,556,557$

Nature, influence of, on South African history, 50

Notwani River, 257

O.

Oak, 35

Orange Free State, 43, I 42, I44, I6II64, 202, 388-398, 419, 527, 594

Orange River, 9, 39

Orange River Sovereignty, I42, I44

Ostrich, 22, 548

Oudzi River, 3 I 5

Ox-wagon, 227-233, 259, $29 \mathrm{I}$

$\mathrm{P}$.

Palapshwye, 260, 265

Panda, I03, I48

Parties (political), 50r

Pasturage, 547

Phillips Lionel, $522 n$.

Physical features, 2-10, 37-49, 543, 568

Pietermaritzburg, 356, 363

Pitso, 42I, 424

Plateau, great interior, $3-6,43,45,55$, I 42, 580

Politics, Natal, 356, 357 Orange Free State, 39r-397

British Colonies, 492 et seq.

Polygamy, I07, 470

Population, I 27, I 68

character of, 494

increase of, $495,547,549,565$. 566,591
Portuguese, 52, 53, 55, I 20-125, 2 I 3 , $214,322,353,354$

Portuguese territories, 53, 322

Pretolia, 218, 385, 386

Pretorius, Andries, I60

Pretorius, M. W., I90, I9I

Protectionists, $496,55^{8}$

Pungwe River, 329-336

\section{Q}

Quathlamba mountain-range, 4, 40, 42, $45,6 \mathrm{r}, 364$

R

Railways, 225-227, 233, 326, 336, 337

Rainfall, 7-10, 33, 38

Religion of the Kafirs, I09-II5, 465

Resources of South Africa, 542-567

Responsible government, I70, 49I et seq., 503, 504

Rhinoceros, 21

Rhodes, Cecil, 213, 219, 245, 503, 523

Rivers, 8-10

\section{S}

Salisbury, Fort, 300, 301

Sand River convention, I6I, I89

Scenery, aspects of, $58-67,268,269$, $287,296-298,305-307,313,314$, $325,333,409,410$

Selous, F. C., 279

Shepstone, Sir T., 192

Silver-tree, 30, 239

Slavery, I07, I 35, I39, 438

Snakes, 23

Social characteristics, $475-490$

Sofala, I21, 335

South African Republic. See TransVAAL

Southern States of America, 452, 457, 498,585

Steamer communications, 223, 224, 588,589

Stellenbosch, 35, I26, $24 \mathrm{I}$

Stores, 290, 308

Swazis, 102, 208, 209

$\mathrm{T}$

Thaba Bosiyo, I53, I78, 4II-4I6

'Thabu 'Ntshu, I44, 400

Tongas, 104, 209

Trade, $48 \mathrm{I}, 588,590$ 
Transvaal, 44, 64, I 42, I44, I45, I90I93, 200, 512, 590

Travelling, 223, 399

Trees, 26-36, 258, 307

Trek, the Great, 142 et seq.

Tsetse-fly, 283, 326

Tshaka, IOI-IO4, I4I, I42, I45, 4 I I

U

Uitlanders, 510, 517, 519, $59 \mathrm{I}$

V

Vaal River, 252

Vandals, I25
Victoria, F ort, 294

Volksraad, 5I3

W

Walfish Bay, 42, 2 I I

Witchcraft, I I4

Witwatersrand, 37I et seq., 480, 553

Z

Zambesi, 5I, I22, I46, 2I2, 216, 283 Zebras, 22

Zimbabwye, 83 et seq.

Zululand, 40, 46, I85, 205, $35^{8}$

Zulus, IOI-IO4, I52, I86, I92, I97

THE END 



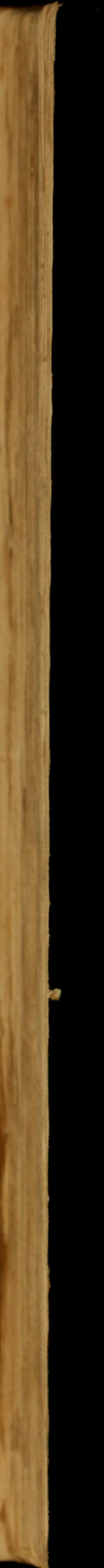


